Universidade de São Paulo

Faculdade de Filosofia, Letras e Ciências Humanas

Departamento de História

Programa de Pós-Graduação em História Econômica

Camila Scacchetti

\title{
"Dai a César o que é de César":
}

Do Dízimo ao ICMS - Raízes da Tributação sobre o Consumo.

Versão Corrigida

São Paulo 
Universidade de São Paulo

Faculdade de Filosofia, Letras e Ciências Humanas

Departamento de História

Programa de Pós-Graduação em História Econômica

Camila Scacchetti

\section{"Dai a César o que é de César": \\ Do Dízimo ao ICMS - Raízes da Tributação sobre o Consumo.}

\section{Versão Corrigida}

Dissertação apresentada ao Programa de PósGraduação em História Econômica do Departamento de História da Faculdade de Filosofia, Letras e Ciências Humanas da Universidade de São Paulo, para a obtenção do título de Mestra em História Econômica.

Área de Concentração: História Econômica

Orientadora: Luciana Suarez Galvão

De acordo,

Luciana Suarez Galvão

São Paulo 
Autorizo a reprodução e divulgação total ou parcial deste trabalho, por qualquer meio convencional ou eletrônico, para fins de estudo e pesquisa, desde que citada a fonte.

Faculdade de Filosofia, Letras e Ciências Humanas da Universidade de São Paulo

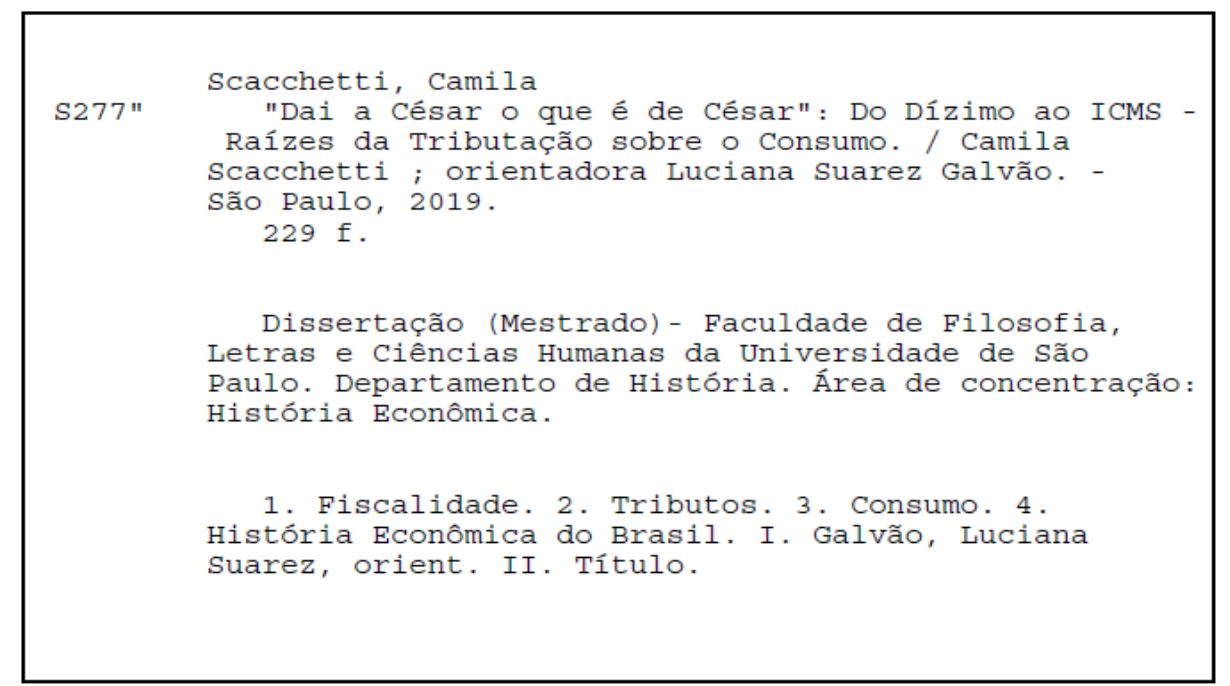




\section{ENTREGA DO EXEMPLAR CORRIGIDO DA DISSERTACÃO/TESE}

\section{Termo de Ciência e Concordância do (a) orientador (a)}

Nome do (a) aluno (a): Camila Scacchetti

Data da defesa: $18 / 02 / 2020$

Nome do Prof. (a) orientador (a): Luciana Suarez Galvão

Nos termos da legislação vigente, declaro ESTAR CIENTE do conteúdo deste EXEMPLAR CORRIGIDO elaborado em atenção às sugestões dos membros da comissão Julgadora na sessão de defesa do trabalho, manifestando-me plenamente favorável ao seu encaminhamento e publicação no Portal Digital de Teses da USP.

São Paulo, 17/04/2020

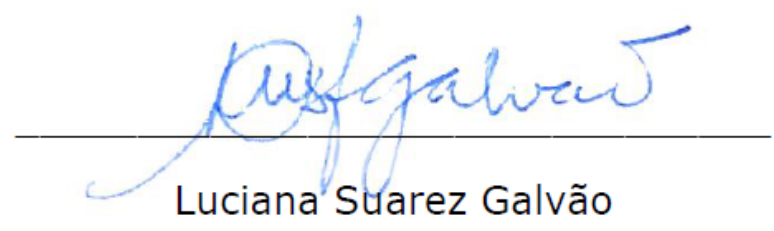


Nome: Camila Scacchetti

Título: "Dai a César o que é de César": Do Dízimo ao ICMS - Raízes da Tributação sobre o Consumo.

Dissertação apresentada ao Programa de PósGraduação em História Econômica do Departamento de História da Faculdade de Filosofia, Letras e Ciências Humanas da Universidade de São Paulo, para a obtenção do título de Mestra em História Econômica.

Aprovada em:

Banca Examinadora

Prof. Dr. Instituição:

Julgamento: Assinatura:

Prof. Dr. Instituição:

Julgamento: Assinatura:

Prof. Dr. Instituição:

Julgamento: Assinatura: 
À Vida e aos seus mais profundos, e gratificantes, misteriosos desígnios! 


\section{Agradecimentos}

Ao Universo, pelo dom da vida, do aprendizado, do crescimento e do desenvolvimento.

À toda a minha ancestralidade, que deixou em mim e para mim a mais preciosa herança: amor, coragem e determinação. Eu os reverencio!

Aos meus pais, Isabel e Wilson, por propiciarem a mim esta oportunidade ímpar em experenciar, cair, levantar e viver. E, a cada nova queda, saber que vocês sempre estarão ao meu lado, me apoiando, me auxiliando e me fortalecendo, estejam onde estiverem.

Às minhas irmãs de alma, coração e sangue, Carolina, Caterine e Amélia, por toda a paciência que sempre tiveram comigo. Vocês são, e sempre foram, fundamentais na minha caminhada. Obrigada pela peraltice, fidelidade, amizade e resignação compartilhadas entre nós. Sem vocês certamente eu não seria a mesma pessoa. Ah, e sim, aquela barriga estava muito apertada, que bom que saímos antes do tempo...

À minha tia/mãe Carmem meu mais profundo agradecimento por todo o apoio, carinho e compreensão. Obrigada por cuidar de mim.

Aos meus sobrinhos, Luana e Gabriel, por me ensinarem repetidamente o dom do amor, da compaixão e da aceitação.

Aos meus parentes de coração, Nilton, Nina, Aron, Alana, Aruan, Lila, Marina, Mateus e Maitê. Obrigada por me ensinarem que a família não se limita às relações consanguíneas. Obrigada por me ensinarem que, em essência, somos todos uma grande e única família.

Aos meus poucos, porém verdadeiros, amigos. Aqueles que já seguiram caminhos distantes dos meus e aqueles que continuam a compartilhar a existência comigo.

À Rafinha, sem você essa jornada certamente não teria sido a mesma. Obrigada pelas risadas, pelos puxões de orelha, pelos ombros e pelo sincero amor e carinho compartilhado entre nós.

À Luciana. Orientadora, guia, professora, mãe, irmã, amiga... Obrigada por acreditar em mim, me abraçar e me estender as mãos em um momento tão delicado e de profundas transformações. A você dedico, e sempre dedicarei, meu mais profundo e sincero agradecimento e respeito!

Por último, mas não menos importante, agradeço à CAPES - Coordenação de Aperfeiçoamento de Pessoal de Nível Superior - pela concessão da Bolsa de Estudos pelo período de 24 meses. Sem este auxílio certamente os caminhos percorridos teriam sido mais árduos. 


\section{Resumo}

SCACCHETTI, Camila. "Dai a César o que é de César": Do Dízimo ao ICMS Raízes da Tributação sobre o Consumo, 2019. 229 f. Dissertação (Mestrado) Faculdade de Filosofia, Letras e Ciências Humanas. Universidade de São Paulo, São Paulo, 2019.

Este estudo tem como objetivo entender a maneira pela qual a estrutura fiscal brasileira foi construída e chegou ao modelo atual, a concentrada incidência tributária sobre o consumo. Sendo assim, a busca por esta compreensão nos conduz, necessariamente, a refazer os passos trilhados pela fiscalidade brasileira no decorrer dos séculos. Como metodologia adotada para a pesquisa analisamos as principais características tributárias de cada uma das regiões que se destacou no decorrer da história brasileira por suas atividades econômicas. Revisitar o Nordeste açucareiro, a exploração aurífera e a expansão cafeeira nos propicia uma rica oportunidade, e profundo entendimento, acerca de como o fisco e os governantes brasileiros se estruturaram, enxergaram o contexto econômico e promoveram a tributação sobre a produção, circulação e consumo de mercadorias. Além disso, o trabalho demonstra que a tributação sobre o consumo foi, desde o início da colonização brasileira, uma tomada de decisão consciente e não um acaso fruto de escolhas impensadas.

Palavras-chave: Fiscalidade; Dízimo; ICMS; Produção; Circulação; Consumo; Bens e Serviços. 


\begin{abstract}
SCACCHETTI, Camila. "Give to Cesar what is to Cesar": From Tithe to ICMS Roots of Taxation on Consumption. 2019. 229 f. Dissertation (Master) - Faculty of Philosophy, Letters and Human Sciences. University of Sao Paulo, Sao Paulo, 2019.
\end{abstract}

This study aims to understand the way in which the Brazilian tax structure was built and reached the current model, the concentrated tax incidence on consumption. Thus, the search for this understanding necessarily leads us to retrace the steps taken by Brazilian taxation over the centuries. As methodology adopted for the research we analyzed the main tax characteristics of each of the regions that stood out in the course of the Brazilian history for its economic activities. Revisiting the sugar Northeast, gold exploration and coffee expansion provides us with a rich opportunity and deep understanding of how the Brazilian tax authorities and rulers have structured themselves, seen the economic context and promoted taxation on the production, circulation and consumption of merchandise. Moreover, the study demonstrates that taxation on consumption has been, since the beginning of Brazilian colonization, a conscious decision-making and not a chance result of unthinking choices.

Keywords: Taxation; Tithe; ICMS, Production; Circulation; Consumption; Goods and Services. 


\section{Índice de Gráficos}

Gráfico 1 - Evolução da Carga Tributária no Brasil - \% PIB, (2002 a 2016)__ 18

Gráfico 2 - Participação das Bases de Incidência na Arrecadação Total, (2016) __ 24

Gráfico 3 - Série Histórica da Participação de Bens e Serviços na Arrecadação Total, (2007 a 2016) _ 24

Gráfico 4 - Representatividade de Bens e Serviços na Arrecadação - Análise Vertical, (2016)___ 30

Gráfico 5 - Tributos por percentual de Arrecadação, (2016) ___ 33

Gráfico 6 - Composição da Receita Tributária no Estado de São Paulo, (2016)___ 37

Gráfico 7 - Arrecadação de ICMS por Setor de Atividade, (2016) __ 39

Gráfico 8 - Série Histórica da Arrecadação com o ICMS, (1994 a 2016) __ 42

Gráfico 9 - Série Histórica da Arrecadação com o ISS, (2009 a 2016) __ 45

Gráfico 10 - Histórico Receita Tributária: Orçado versus Realizado, (2009 a 2016) __ 47

Gráfico 11 - Histórico Receita Realizada, (2009 a 2016)___ 48

Gráfico 12 - Despesas e Receitas, (1823 - 1830/1831)__ 120

Gráfico 13 - Composição da Receita, $(1823$ - 1830/1831) __ 120

Gráfico 14 - Evolução dos Direitos de Saída. São Paulo, (1835-1889)___ 171

Gráfico 15 - Participação percentual dos Impostos de Importação, Consumo e Renda no Total da Receita

da União, (1900-1930)___ 183

Gráfico 16 - Participação Relativa por Produto na Receita do Imposto de Consumo, (1925) ___ 184

\section{Índice de Imagens}

Imagem 1 - Marco Estrada Real localizado em São Gonçalo do Rio das Pedras/MG __ 85

Imagem 2 - Edifícios da Antiga Intendência e Casa de Fundição, Diamantina/MG___ 88

Imagem 3 - Antigo Registro situado na região limítrofe entre Serro/MG e Diamantina/MG___ 90

Imagem 4 - Antiga Casa dos Contratos, Diamantina/MG __ 91

Imagem 5 - Rendimento Fiscal da Capitania de Minas Gerais: Quintos, Dízimos e Entradas de

Mercadorias, (1700-1820) 95

Imagem 6 - Evolução da média de Arrecadação dos Direitos da Dízima da Alfândega do Rio de Janeiro, (1741-1804) 100

Imagem 7 - Lei no 2.486, de 16/12/1935__ 197

Imagem 8 - Lei ${ }^{\circ} 1.529$, de 28/12/1916__ 198

Imagem 9 - Lei ${ }^{\circ} 1.303$, de 30/12/1911__ 199

Imagem 10 - Lei $n^{\circ}$ 936, de 17/08/1904 _ 200

Imagem 11 - Lei $n^{\circ} 15$, de 11/11/1891_ 201

Imagem 12 - Lei $n^{\circ} 17$, de 26/03/1840 _ 202

Imagem 13 - Lei ${ }^{\circ} 17$, de 11/04/1835 __ 203

\section{Índice de Mapas}

Mapa 1 - O Caminho Velho __ 83

Mapa 2 - O Caminho Novo___ 84 


\section{Índice de Quadros}

Quadro 1 - Carga Tributária Bruta, (2015 e 2016) __ 17

Quadro 2 - Carga Tributária Total: Brasil, América Latina e Caribe - \% PIB, (2006 a 2015)___ 19

Quadro 3 - Carga Tributária: Brasil e Países da OCDE, (2015)__ 20

Quadro 4 - Evolução da Carga Tributária: Brasil e Média OCDE, (\% PIB)__ 21

Quadro 5 - Carga Tributária e Variação por Base de Incidência, (2015 e 2016)___ 23

Quadro 6 - Evolução da Participação das Bases de Incidência na Arrecadação Total, (2007 a 2016) _ 25

Quadro 7 - Carga Tributária por Ente Federativo, (2015 e 2016) _ 26

Quadro 8 - Receita Tributária Federal por Base de Incidência, (2016)__ 28

Quadro 9 - Receita Tributária Estadual por Base de Incidência, (2016)__ 28

Quadro 10 - Receita Tributária Municipal por Base de Incidência, (2016)__ 29

Quadro 11 - Receita Tributária por Base de Incidência e Nível de Governo - Análise Vertical, (2016) _ 29

Quadro 12 - Receita Tributária por Relevância do Tributo: $1^{\circ}$ ao $10^{\circ}$, (2015 e 2016)___ 31

Quadro 13 - Receita Tributária por Relevância do Tributo: $11^{\circ}$ ao $20^{\circ}$, (2015 e 2016)___ 31

Quadro 14 - Receita Tributária por Relevância do Tributo: $21^{\circ}$ ao $37^{\circ},(2015$ e 2016)__ 32

Quadro 15 - Arrecadação Mensal do ICMS no Brasil, (2015 e 2016)___ 35

Quadro 16 - Arrecadação Mensal do ICMS: Brasil exceto São Paulo, (2015 e 2016) __ 35

Quadro 17 - Arrecadação Mensal do ICMS em São Paulo, (2015 e 2016) __ 36

Quadro 18 - Arrecadação de ICMS por Setor de Atividade, (2016) __ 38

Quadro 19 - Arrecadação de ICMS por Região, (2016)___ 40

Quadro 20 - Histórico da Receita Tributária, (1994 a 2016) ___ 41

Quadro 21 - Receita Tributária do Município de São Paulo, (2016) ___ 44

Quadro 22 - Histórico Receita Tributária: Orçado versus Realizado, (2009 a 2016) ___ 46

Quadro 23 - Propostas de Reforma Tributária em Pauta __ 51

Quadro 24 - Conta Corrente dos Contratos dos Dízimos e das Entradas, (1722-1765)___ 94

Quadro 25 - Valor do Contrato dos Dízimos e da Dízima da Alfândega no Rio de Janeiro, (1710-1751) 99

Quadro 26 - Balanço Financeiro do Império, (1823 a 1827)___ 117

Quadro 27 - Balanço Financeiro do Império, (1828 a 1831)___ 119

Quadro 28 - Relação dos Tributos Incidentes sobre a Alfândega, (1828) __ 122

Quadro 29 - Relação dos Tributos Incidentes sobre os Gêneros, (1828)___ 125

Quadro 30 - Relação dos Tributos Incidentes sobre Passagens e Registros, (1828) __ 127

Quadro 31 - Relação dos Tributos Incidentes sobre Propriedade e Renda, (1828) __ 129

Quadro 32 - Relação dos Tributos Incidentes sobre Botequins e Tabernas, Chancelaria, Contratos,

Diamantes/Ouro e Moeda, (1828)__ 130

Quadro 33 - Tributos Diversos, (1828)___ 131

Quadro 34 - Receita da Província de São Paulo, (1827)___ 135

Quadro 35 - Quadro Geral do Orçamento da Receita do Tesouro Nacional em todo o Império - $1^{\circ}$

Semestre de 1830 e Ano Financeiro de $1^{\circ}$ de julho de 1830 a 30 de junho de $1831 \_138$

Quadro 36 - Produção Total da Província de São Paulo, (1836) __ 153

Quadro 37 - Resumo do Balanço da Receita de São Paulo, (1835-1836) ___ 155

Quadro 38 - Arrecadação do Imposto de Consumo, (1892-1920) __ 182

Quadro 39 - Do Dízimo ao ICMS, São Paulo___ 204

Quadro 40 - O Imposto sobre Indústria e Profissões na Lei Orçamentária do Império, (1836-1870) _ 210 


\section{Índice de Tabelas}

Tabela 1 - Evolução da Receita Provincial Orçada. São Paulo, (1835-1889) ___ 158

Tabela 2 - Lei Orçamentária no 17, de 11 de abril de 1835 _ 159

Tabela 3 - Evolução dos Direitos de Saída. São Paulo, (1835-1839)___ 159

Tabela 4 - Lei Orçamentária nº 17, de 26 de março de $1840 \ldots 161$

Tabela 5 - Evolução dos Direitos de Saída. São Paulo, (1840-1849)___ 161

Tabela 6 - Lei Orçamentária no 24, de 02 de julho de $1850 \ldots 163$

Tabela 7 - Evolução dos Direitos de Saída. São Paulo, (1850-1859)___ 164

Tabela 8 - Lei Orçamentária no 16, de 03 de agosto de $1861 \ldots 164$

Tabela 9 - Evolução dos Direitos de Saída. São Paulo, (1861-1869)___ 165

Tabela 10 - Lei Orçamentária no 93, de 21 de abril de $1870 \ldots 166$

Tabela 11 - Evolução dos Direitos de Saída. São Paulo, (1870-1877)___ 167

Tabela 12 - Lei Orçamentária n ${ }^{\circ}$ 156, de 29 de abril de $1880 \ldots 168$

Tabela 13 - Evolução dos Direitos de Saída. São Paulo, (1880-1889)___ 169

Tabela 14 - Lei Orçamentária $n^{\circ}$ 107, de 09 de abril de $1889 \ldots 170$

Tabela 15 - Participação dos Direitos de Saída na Receita Orçada, (1835-1889) __ 170

Tabela 16 - Os Direitos de Saída na São Paulo Imperial: Orçado versus Realizado __ 171 


\section{Lista de Abreviaturas}

ALESP - Assembleia Legislativa do Estado de São Paulo

CIDE - Contribuição de Intervenção do Domínio Econômico

COFINS - Contribuição para o Financiamento da Seguridade Social

CPMF - Contribuição Provisória sobre Movimentação ou Transmissão de Valores e de Créditos e Direitos de Natureza Financeira

IBGE - Instituto Brasileiro de Geografia e Estatística

IBS - Imposto sobre Bens e Serviços

ICM - Imposto sobre Circulação de Mercadorias

ICMS - Imposto sobre Circulação de Mercadorias e Serviços de Transporte Interestadual, Intermunicipal e de Comunicação

IE - Imposto de Exportação

II - Imposto de Importação

IOF - Imposto sobre Operações Financeiras

IPCA - Índice de Preços ao Consumidor Amplo

IPI - Imposto sobre Produtos Industrializados

IPVA - Imposto sobre a Propriedade de Veículos Automotores

ISS - Imposto sobre Serviços de Qualquer Natureza

ITCMD - Imposto sobre Causa Mortis e Doação

IVA - Imposto sobre Valor Agregado/Adicionado

IVC - Imposto sobre Vendas e Consignações

OCDE - Organização de Cooperação e de Desenvolvimento Econômico

PASEP - Programa de Formação do Patrimônio do Servidor Público

PEC - Proposta de Emenda à Constituição

PIB - Produto Interno Bruto

PIS - Programa de Integração Social

RFB - Receita Federal do Brasil

TIPI - Tabela de Incidência do Imposto sobre Produtos Industrializados 


\section{Sumário}

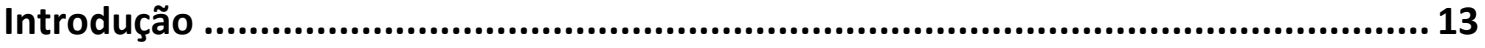

Capítulo 1 - 0 Contexto Atual: A Representatividade de Bens e Serviços nas Finanças

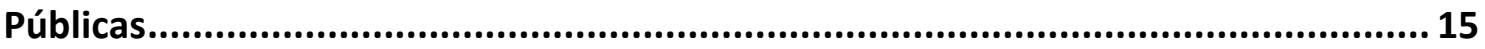

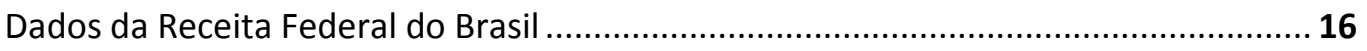

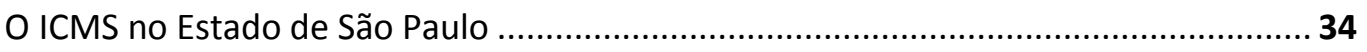

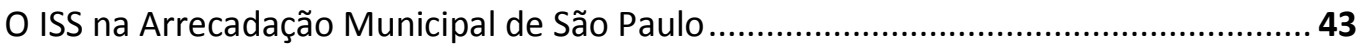

O Imposto Único sobre Bens e Serviços ...................................................................... 49

Capítulo 2 - Notas Sobre a Tributação no Brasil Colônia.......................................... 55

Dízimos e os Impostos Alfandegários, Séculos XVI e XVII ...........................................56

A Tributação sobre a Circulação, Século XVIII ............................................................. 76

Capítulo 3 - Notas Sobre a Tributação no Brasil Império ...................................... 102

A Chegada da Corte: Repensando a Estrutura Tributária .......................................... 102

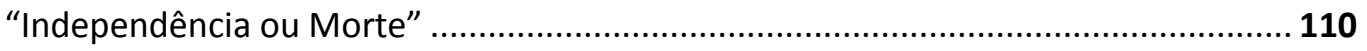

A Construção do Estado Nacional e os Direitos de Saída .............................................. 139

Capítulo 4 - Raízes da Tributação Sobre o Consumo............................................ 175

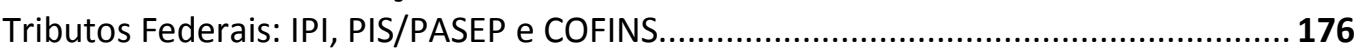

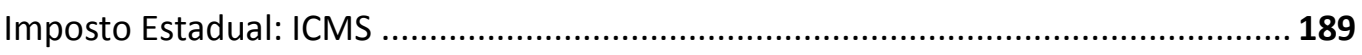

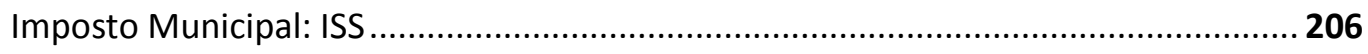

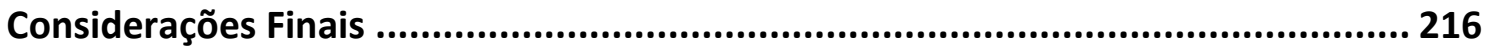

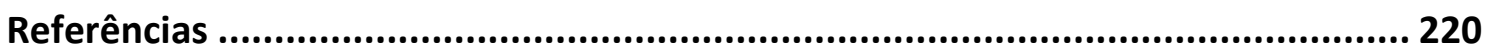




\section{Introdução}

“Comprou, pagou! Pagou o quê, pagou quanto, pagou para quem?"

Questionamentos que mais parecem uma transação comercial em essência ilustram a relação do contribuinte com o fisco brasileiro. Se, há dois mil anos, nos foi orientado "Dai a César o que é de César", atualmente ansiamos saber como esta relação foi construída.

De que maneira o povo brasileiro contribui com a parcela devida a "César"? Seria por meio da tributação incidente sobre a renda, sobre o salário, sobre a propriedade, sobre os ganhos de capital? Ou seria, predominantemente, sobre as trocas comerciais cotidianas?

Para respondermos estas questões apresentaremos as ferramentas tributárias mais comumente utilizadas pela Fazenda brasileira. Além disso, abordaremos os dados atuais da arrecadação fiscal das três esferas governamentais: União, Estado e Município.

Esta reflexão possui como objetivo demonstrar que o sistema fiscal brasileiro promove a maior parcela de seu recolhimento por meio da tributação incidente sobre o consumo. Para tanto, a lógica intrínseca ao modelo estabelece a inserção da alíquota do tributo no preço da mercadoria. Diante deste evento a população, de um modo geral, permanece sem saber ao certo o quanto de seus recursos próprios foi transferido para os cofres públicos.

Feito este diagnóstico, demonstraremos as principais propostas de Reforma Tributária em tramitação no Congresso Nacional. O conhecimento destes debates nos permitirá refletir acerca dos caminhos a serem percorridos pela fiscalidade brasileira, os desdobramentos de tais escolhas e o entendimento acerca de uma possível ruptura ou continuidade do modelo vigente.

No entanto, como avaliarmos sobre possíveis rupturas ou continuidades sem conhecermos o passado fiscal brasileiro? Quais teriam sido as alternativas encontradas pelo fisco português quando deu início ao processo de colonização do Brasil? Como teriam promovido a tributação em uma terra que tinha como propósito suprir o mercado consumidor europeu por meio do fornecimento de gêneros primários? Estas indagações serão respondidas por meio da análise do Nordeste açucareiro. 
Ainda no Brasil Colônia, quais teriam sido os caminhos percorridos pelo Erário luso quando da descoberta do ouro? Teria a Coroa pensado em uma nova estrutura fiscal ou tão somente incorporado novas ferramentas tributárias ao modelo construído no decorrer dos séculos XVI e XVII? As pesquisas sobre o cotidiano fiscal na região das Minas Gerais nos fornecerão o mapa, o "caminho do ouro", para tais esclarecimentos.

No início do século XIX o Brasil vivenciou profundas transformações políticas com a vinda da Corte, a Proclamação da Independência e a posterior abdicação de D. Pedro I e chegada ao poder de grupos da elite brasileira. Em paralelo, as atividades econômicas provenientes do comércio do açúcar e da extração do ouro estavam muito aquém de seus tempos de glória. Teriam estes movimentos ocasionado alterações no modelo fiscal brasileiro, ou apenas observamos a continuidade das escolhas feitas no passado, independente da realidade econômica e política vivenciada no período?

Ademais, de que maneira o incipiente e próspero complexo cafeeiro teria promovido uma nova dinâmica no modelo fiscal brasileiro, se é que promoveu? Esta elucidação se dará por meio do estudo do novo centro econômico do país, São Paulo na segunda metade do Oitocentos.

Em síntese, ansiamos entender quais foram os passos dados rumo à construção do modelo tributário brasileiro vigente no século XXI. As escolhas e medidas adotadas no século XVI ainda estariam presentes e atuantes no cotidiano fiscal brasileiro? Ao analisarmos as principais características fiscais de cada região brasileira que se destacou no cenário nacional por sua atividade econômica e representou a "joia do Tesouro" em seu período áureo, temos como propósito efetuar um mapeamento da construção do modelo tributário brasileiro no decorrer dos séculos. Sendo assim, nos ocuparemos em responder: Como chegamos neste "estado de coisas"? 


\section{Capítulo 1}

\section{O Contexto Atual: A Representatividade de Bens e Serviços nas Finanças Públicas}

Desde os primórdios da civilização os governantes procuram meios de arrecadar recursos a fim de cumprir com seus deveres perante a população. Arrecadam bens monetários da sociedade e devolvem a ela serviços dito essenciais. Desta forma, os tributos representam a mais importante fonte de renda dos governos para que estes propiciem o bem-estar de seus cidadãos e ao mesmo tempo executem suas obrigações orçamentárias e administrativas. A esta função essencialmente arrecadatória denomina-se a função fiscal tributária.

Contudo, ledo engano atribuir aos tributos apenas a função arrecadatória a fim de suprir o Erário. Os tributos, assim como outras ferramentas que o governo pode dispor, também obedecem ao objetivo de promover políticas socioeconômicas com o intuito de atingir as metas primordiais estabelecidas para o equilíbrio da Nação. Sendo assim, além da função arrecadatória, ao tributo também cabe as funções distributiva, alocativa (indutora) e estabilizadora. Tem-se através destas atuações a função extrafiscal tributária.

Ao concentrarmos as análises na função fiscal, arrecadatória, procuraremos demonstrar o dispositivo utilizado pelo governo brasileiro para promover a transferência de recursos dos agentes particulares para os agentes públicos. Para tanto, serão estudados os números apresentados pela Secretaria da Receita Federal do Brasil (RFB), Secretaria da Fazenda do Estado de São Paulo e Secretaria da Fazenda do Município de São Paulo ${ }^{1}$ Por meio dos documentos governamentais é possível constatar quais são os tributos mais representativos para os entes federativos. Cabe salientar que os números apresentados a seguir foram extraídos dos balanços governamentais e não de seus orçamentos. Sendo assim, serão ilustrados os valores de fato arrecadados na esfera tributária.

\footnotetext{
${ }^{1}$ Em tópicos posteriores será apresentada a representatividade que o ICMS paulista possui diante da arrecadação nacional. Em média, 30\% da renda gerada pelo ICMS é oriunda do Estado de São Paulo. Diante deste fato, adotou-se como instrumental metodológico o estudo sobre o território paulista e sua capital, nas análises sobre o ISS.
} 


\section{Dados da Receita Federal do Brasil}

Por intermédio dos relatórios divulgados anualmente pela Receita Federal do Brasil são apresentados aos contribuintes os números referentes à carga tributária brasileira, bem como a representatividade de cada um dos tributos vigentes. Os estudos tributários e aduaneiros, normalmente divulgados no segundo semestre do ano, retratam o montante das cifras que foram transferidas para o governo no ano-calendário anterior. As arrecadações apresentadas adiante foram extraídas do estudo Carga Tributária no Brasil 2016 - Análise por Tributos e Bases de Incidência, divulgado em dezembro de 2017.

Quanto à metodologia adotada para a transcrição dos números, procuramos compilar fielmente as informações originais disponíveis no relatório da Receita Federal do Brasil. No entanto, para melhor visualização e oportunidade de comparação entre os dados, algumas tabelas do relatório original da RFB foram alteradas e/ou informações apresentadas na forma de gráfico, no texto original, foram convertidas em Quadros. São os casos do Quadro 02, Quadro 03, Quadro 05, Quadro 08, Quadro 09 e Quadro 10.

Além disso, adotou-se como critério de análise, na etapa inicial, a discussão acerca dos números agregados. Paulatinamente, serão apresentados os detalhes arrecadatórios, até chegarmos na representatividade por tributo. Desta maneira, os dados expostos neste estudo não seguem a mesma sequência apresentada no relatório da Receita Federal do Brasil.

\section{A carga tributária brasileira}

Os números apresentados na sequência retratam uma realidade há muito sentida pelos brasileiros, a elevada carga tributária nacional. No entanto, saberiam os brasileiros apontar quais são as principais ferramentas de recolhimento tributário governamental? Teria a população consciência do quantum, de fato, contribui com seus recursos próprios para a receita da Federação? Tais questionamentos podem até parecer óbvios e superficiais, todavia, possuem em si profundos aspectos da construção histórica fiscal brasileira, são essenciais e irão nortear as linhas desta pesquisa. 


\section{Quadro 1 - Carga Tributária Bruta, (2015 e 2016)}

\begin{tabular}{|c|c|c|}
\hline \multicolumn{2}{c}{ R \$ Bilhões } \\
\hline Componentes & $\mathbf{2 0 1 5}$ & $\mathbf{2 0 1 6}$ \\
\hline Produto Interno Bruto & $5.995,79$ & $6.259,23$ \\
\hline Arrecadação Tributária Bruta & $1.925,45$ & $2.027,01$ \\
\hline Carga Tributária Bruta & $32,11 \%$ & $32,38 \%$ \\
\hline
\end{tabular}

De acordo com o exposto no Quadro 01, no ano de 2015 a arrecadação tributária totalizou pouco mais de $32 \%$ do PIB, promovendo para os cofres públicos a transferência de um montante de quase R \$ 2 trilhões. Em 2016 ocorreu uma elevação irrisória neste sentido, favorecendo uma arrecadação pouco superior a $\mathrm{R} \$ 2$ trilhões ${ }^{2}$. Os números apresentados neste estudo são reproduzidos de acordo com o informado no relatório da Receita Federal do Brasil, sendo assim, em valores nominas. Desta maneira, a inflação do período não é considerada.

Neste momento, algumas considerações se fazem pertinentes. Não poderia nos passar despercebido o conturbado contexto econômico e político vivenciado pelo Brasil entre os anos 2015 e 2016. Neste biênio o país enfrentou altos índices inflacionários, de desemprego e recessão econômica. Ademais, a partir de 2014 vieram à tona os escândalos de corrupção envolvendo o governo, empresas estatais e empresas particulares. Conduzida pela Polícia Federal, a operação Lava Jato deflagrou um sofisticado esquema de lavagem de dinheiro, pagamento de propinas e contribuições financeiras de empresas

\footnotetext{
2 "Notas Metodológicas: C-01 Critério Geral - Para efeito deste trabalho, também são considerados tributos receitas que: (i) tenham natureza de poupança compulsória ou seguro (como no caso do FGTS), (ii) vinculem-se a uma prestação futura do Estado (contribuições para a previdência social) ou (iii) sejam apropriados por entes paraestatais (Sistema S). Sempre que o detalhamento da informação permita, os valores de receita são informados depois de descontados os seguintes valores: Restituições efetivamente pagas aos contribuintes. Os valores restituídos são contrapartida de pagamentos e/ou retenções realizados em montante superior ao devido, logo não são considerados como recursos efetivamente transferidos da esfera privada para os cofres do Estado; Juros moratórios. O valor dos juros pagos decorrente de pagamentos extemporâneos de tributos representa, em última análise, o ressarcimento do custo de oportunidade incorrido pela não disposição do valor no período inadimplido e, portanto, abarca fatores não-tributários, como risco, solvência monetária, etc.; Multas em geral. As multas são penalidades ou sanções pecuniárias cuja origem é o não cumprimento da lei lato sensu, vinculando-se, eventualmente, a um comando de natureza tributária. A essência punitiva da multa a afasta do campo tributário. Logo, não se deve confundir o tributo, exigido de uma forma sistemática e regular de todo cidadão, com a multa, exigida excepcionalmente do cidadão que não cumpre a regra legal tributária. C-02 Regime de Apropriação das Receitas - As receitas tributárias são consideradas em cada período (ano-calendário) segundo o momento em que os recursos ingressaram nos cofres públicos, independente do período de ocorrência do fato gerador. Em outras palavras, utiliza-se o regime de caixa para apurar a carga tributária". (RFB, 2017, p. 42).
} 
particulares para as campanhas eleitorais por meio de Caixa 2. Tais denúncias, somadas à fragilidade econômica, culminaram no impeachment da Presidente da República, Dilma Rousseff, em agosto de 2016.

Contudo, mesmo diante de tão alvoroçado momento histórico, o desempenho arrecadatório observado nos anos de 2015 e 2016 não fugiu à regra. De acordo com a série apresentada no Gráfico 01, no decorrer dos últimos 15 anos a média da carga tributária bruta alcançou 32,64\% do Produto Interno Bruto. O ano de 2007 apresentou a maior arrecadação do período, aproximadamente 33,7\% do PIB. O ano de 2003 contribuiu para o menor recolhimento, $31,37 \%$ do PIB.

\section{Gráfico 1 - Evolução da Carga Tributária no Brasil - \% PIB, (2002 a 2016)}

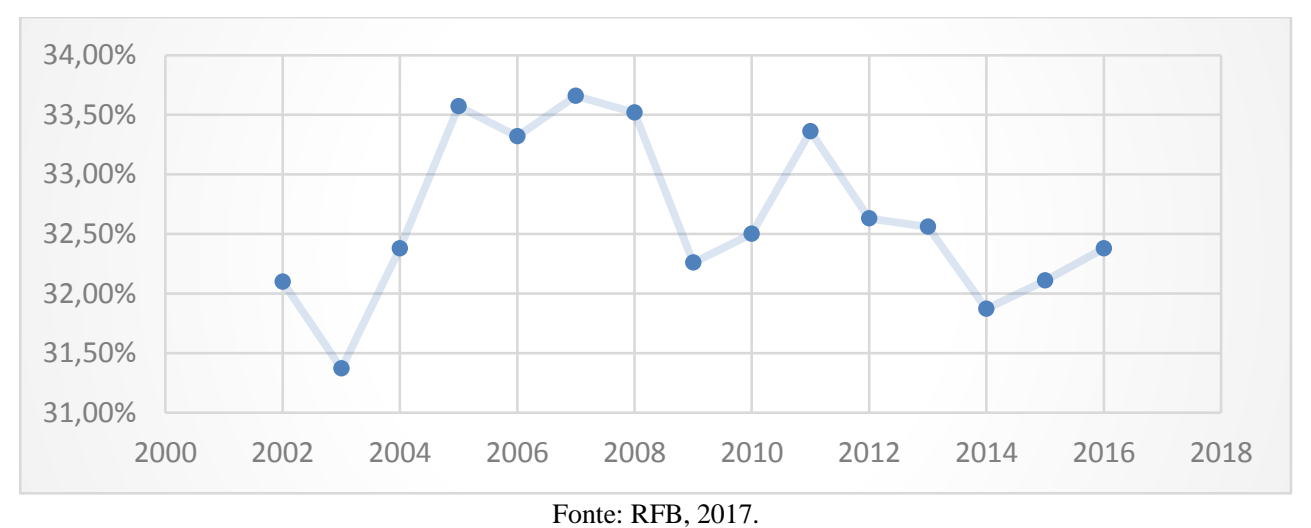

\section{Comparações internacionais}

Com o intuito de não perdermos de vista o desempenho arrecadatório do Brasil frente aos seus vizinhos geográficos, apresentamos no Quadro 02 os dados históricos de 24 países, situados na América Latina e Caribe, os países foram organizados em ordem alfabética.

Ao analisarmos os percentuais de recolhimento podemos averiguar que, empatado com a Argentina, o Brasil ocupou o segundo lugar do ranking em 2015. Neste ano, ambos os países promoveram uma transferência de recursos para os cofres públicos de $32,1 \%$ do PIB. Todavia, a média histórica brasileira, dentre o período ilustrado, é superior à média argentina: $32,79 \%$ versus $29,14 \%$, respectivamente. 
Quadro 2 - Carga Tributária Total: Brasil, América Latina e Caribe - \% PIB, (2006 a 2015)

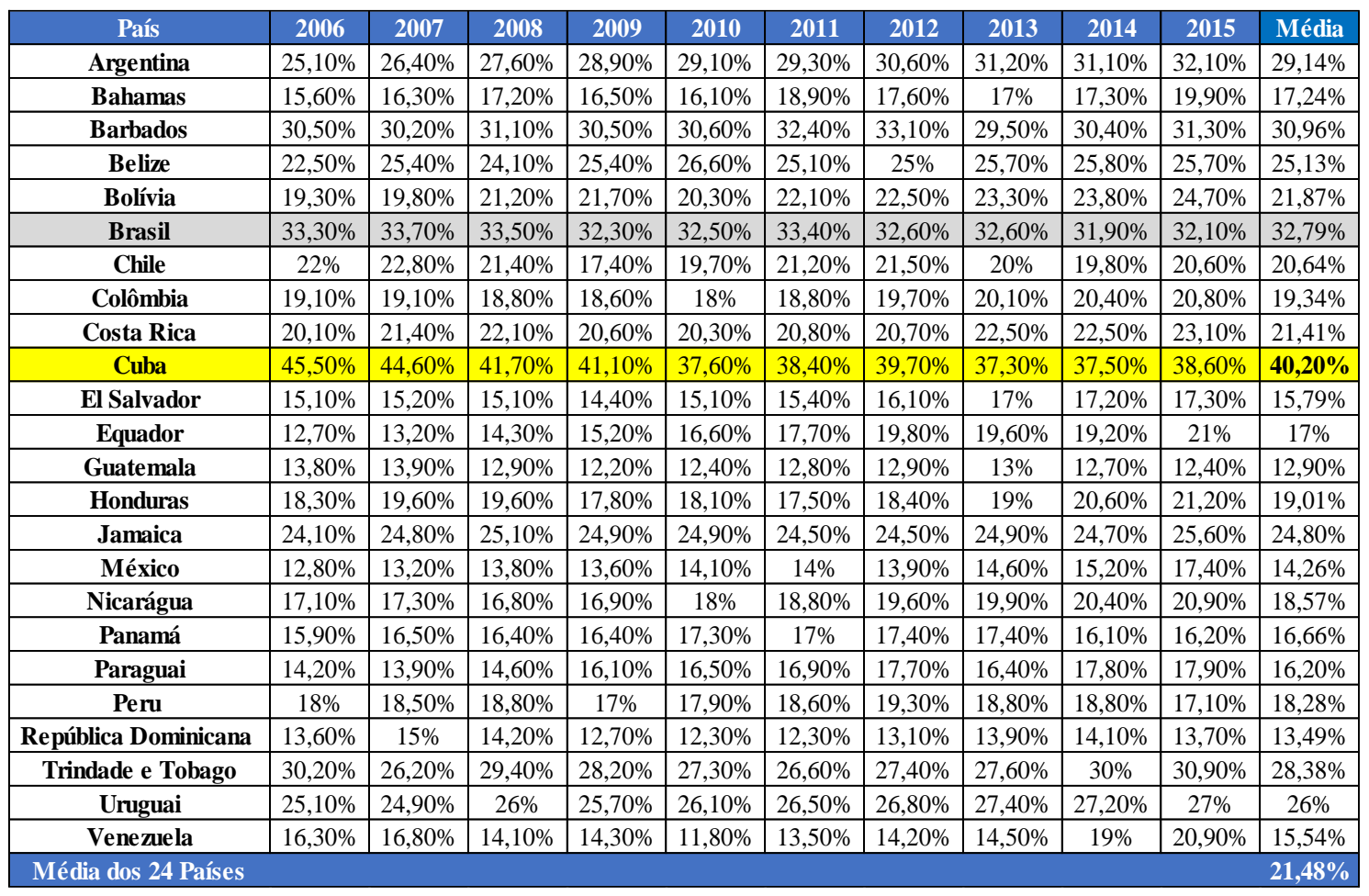

Fonte: RFB, 2017.

Ao compararmos os números brasileiros com os dos demais integrantes do estudo verificamos que, tanto no ano de 2015 quanto na média histórica, o Brasil permanece no segundo lugar. A primeira posição é ocupada por Cuba, destacada no Quadro 02, com uma média de recolhimento de 40,2\% do PIB dentre a década estudada, e com a carga tributária de 38,6\% do PIB em 2015. No outro extremo da análise estão países como Guatemala, República Dominicana e México, que apresentam uma carga tributária total inferior a $15 \%$ do PIB, em média.

Outro ponto a ser evidenciado é o fato de a média histórica da carga tributária dos 24 países ser de 21,48\%, contra 32,79\% da ex-colônia portuguesa. Deste modo, é possível afirmar que o Brasil possui a maior carga tributária dentre os países situados na América do Sul, e a segunda maior dentre os 24 países apresentados no Quadro 02.

Todavia, para não nos limitarmos aos encargos tributários da América Latina, e termos uma base de contraposição mais ampla e de economias mais desenvolvidas, extraímos do relatório da RFB os números que comparam os dados arrecadatórios do Brasil e dos países membros da Organização para a Cooperação e Desenvolvimento Econômico (OCDE), conforme ilustrado do Quadro 03. 
Quando contrastamos os números brasileiros com os dos países que compões a OCDE torna-se clara a evidência de que grande parte das nações de economias mais desenvolvidas possuem uma carga tributária superior à brasileira. Nesta comparação, Dinamarca ocupa o lugar de liderança, com uma carga tributária de 46,6\% do PIB no ano de 2015. Dentre os 33 países apresentados, o Brasil ocupa a $23^{a}$ posição. Importante evidenciarmos que a média arrecadatória destas nações é pouco superior aos números brasileiros, de $34,52 \%$ versus $32,1 \%$, respectivamente. Tal cenário é inverso ao constatado quando comparamos os dados do Brasil com os países da América Latina e Caribe.

Quadro 3 - Carga Tributária: Brasil e Países da OCDE, (2015)

\begin{tabular}{|c|c|c|c|}
\hline País & $\%$ PIB & País & $\%$ PIB \\
\hline Alemanha & $36,90 \%$ & Irlanda & $23,60 \%$ \\
\hline Áustria & $43,50 \%$ & Islândia & $37,10 \%$ \\
\hline Bélgica & $44,80 \%$ & Israel & $31,40 \%$ \\
\hline Brasil & $32,10 \%$ & Itália & $43,30 \%$ \\
\hline Canadá & $31,90 \%$ & Latívia & $29 \%$ \\
\hline Chile & $20,60 \%$ & Luxemburgo & $37 \%$ \\
\hline Coréia do Sul & $25,30 \%$ & México & $17,40 \%$ \\
\hline Dinamarca & $46,60 \%$ & Noruega & $38,10 \%$ \\
\hline Eslovênia & $36,60 \%$ & Nova Zelândia & $32,80 \%$ \\
\hline Espanha & $33,80 \%$ & Portugal & $34,50 \%$ \\
\hline Estados Unidos & $26,40 \%$ & Reino Unido & $32,50 \%$ \\
\hline Estônia & $33,60 \%$ & República Eslováquia & $32,30 \%$ \\
\hline Finlândia & $44 \%$ & República Tcheca & $33,50 \%$ \\
\hline França & $45,50 \%$ & Suécia & $43,30 \%$ \\
\hline Grécia & $36,80 \%$ & Suíça & $27,90 \%$ \\
\hline Holanda & $37,80 \%$ & Turquia & $30 \%$ \\
\hline Hungria & $39,40 \%$ & Média & $\mathbf{3 4 , 5 2 \%}$ \\
\hline & Fonte: RFB, 2017. & \\
\hline
\end{tabular}

A partir deste momento daremos início aos estudos sobre o instrumental utilizado para efetuar o recolhimento dos recursos fiscais. Cabe a observação sobre as bases de incidência mais representativas entre o Brasil e os países que compõem a OCDE. As informações foram sintetizadas no Quadro 04. 


\section{Quadro 4 - Evolucão da Carga Tributária: Brasil e Média OCDE, (\% PIB)}

\begin{tabular}{|c|c|c|c|c|c|c|c|c|c|c|}
\hline & \multicolumn{2}{|c|}{ Carga Tributtáiia Total } & \multicolumn{2}{|c|}{ Renda, Lucros e Ganhos de Capital } & \multicolumn{2}{|c|}{ Folha de Salários } & \multicolumn{2}{|c|}{ Bens e Serviços } & \multicolumn{2}{|c|}{ Outros } \\
\hline & 2006 & 2015 & 2006 & 2015 & 2006 & 2015 & 2006 & 2015 & 2006 & 2015 \\
\hline Brasil & $33,3 \%$ & $32,1 \%$ & $6,2 \%$ & $5,9 \%$ & $8,2 \%$ & $8,4 \%$ & $16,1 \%$ & $15,8 \%$ & $1,6 \%$ & $0,6 \%$ \\
\hline Média OCDE & $34,7 \%$ & $35,2 \%$ & $12,3 \%$ & $11,8 \%$ & $9,1 \%$ & $9,8 \%$ & $11,1 \%$ & $11,4 \%$ & $0,2 \%$ & $0,2 \%$ \\
\hline
\end{tabular}

Ao analisarmos os dados do Brasil notamos que quase todas as fontes arrecadatórias apresentaram queda, com exceção da base de incidência Folha de Salários, que demonstrou uma tímida elevação de arrecadação entre 2006 e 2015. O mesmo movimento não se repete quando estudamos os números da OCDE. Neste caso, apenas Renda, Lucros e Ganhos de Capital retratou uma queda nos dados de arrecadação, enquanto nos demais itens observamos uma elevação.

Iremos concentrar nossa atenção em duas bases de incidência específicas: Renda, Lucros e Ganhos de Capital e Bens e Serviços. A primeira, em termos gerais, tributa os cidadãos que possuem mais recursos financeiros. Trata-se de uma tributação progressiva, pois quanto maior a renda, lucro e ganho de capital do indivíduo, maior será a parte que este deverá contribuir para o fisco. Conforme observamos no Quadro 04, esta base de incidência representa a maior fonte de arrecadação dos países da OCDE e, paralelamente, a menor do Brasil. Tanto no ano de 2006 quanto no de 2015 a média percentual do PIB arrecadado com esta base de incidência foi, nos países da OCDE, praticamente o dobro da brasileira. Em 2006 foram transferidos para os cofres públicos dos países da OCDE, através de Renda, Lucros e Ganhos de Capital, 12,3\% do PIB, versus 6,2\% do PIB brasileiro. Em 2015 tem-se o mesmo comportamento: 11,8\% em oposição a 5,9\%.

Ao analisarmos os dados de Bens e Serviços, verificamos que em ambos os anos o Brasil tributou mais do que os países da OCDE por meio desta base de recolhimento. No ano de 2006 o Brasil recolheu 16,1\% do PIB por meio deste instrumental; os países da OCDE, em média, 11,1\%. Em 2015 foram transferidos para os cofres públicos brasileiros 15,8\% do PIB, em contraste com $11,4 \%$ na OCDE.

A base Bens e Serviços transfere para o Erário parte dos recursos gerados por meio da produção e circulação de mercadorias e prestação de serviços. Em suma, promove a tributação sobre o consumo. Desta forma, no momento da aquisição de um produto ou 
serviço caberá ao consumidor, o contribuinte final, o ônus tributário. Esta base não leva em consideração a capacidade contributiva do cidadão, pois suas alíquotas são fixas e previamente determinadas pelos entes federativos responsáveis por cada tributo. A mesma alíquota irá recair sobre os consumidores, independentemente de o cidadão ser um trabalhador assalariado ou um indivíduo de alto poder aquisitivo. Diante de tal aspecto, podemos constatar que se trata de uma tributação regressiva, pois tais tributos possuem um peso proporcionalmente maior no orçamento das famílias menos abastadas.

Outra relevante questão a ser esclarecida refere-se ao fato de, por meio de Rendas, Lucros e Ganhos de Capital, o contribuinte possui conhecimento do quanto está sendo tributado, pois aufere que a tributação está diretamente relacionada às suas rendas e lucros. $\mathrm{O}$ indivíduo possui consciência que está diante de uma tributação diretamente proporcional às suas posses. Todavia, no caso de Bens e Serviços, os tributos estão embutidos no preço do bem ou serviço a ser consumido. Não há clareza para o consumidor quanto ao valor que de fato foi pago pelo produto adquirido ou serviço prestado e o montante que foi transferido para o governo. Sendo assim, o tributo está inserido e oculto no preço da mercadoria e raramente é detectado pelo contribuinte. A seguir analisaremos a distribuição da carga tributária brasileira entre as fontes de recolhimento fiscal.

\section{Arrecadação brasileira por base de incidência}

Antes de analisarmos as fontes tributárias e sua representatividade de arrecadação diante do PIB, cabe uma breve explicação sobre como está organizada a estrutura tributária brasileira.

Os mecanismos de receita fiscal estão divididos em seis bases de incidência, utilizadas pela Receita Federal do Brasil para a separação e classificação do fato gerador do tributo. Segue breve descrição das bases com seus respectivos códigos de identificação:

- 0000 - Total de Receitas Tributárias: Totalizador dos valores das seis categorias de incidência (itens 1000 a 9000). Corresponde ao valor total arrecadado, descontadas as restituições, multas e juros, nas três esferas de governo;

- 1000 - Tributos sobre a Renda: Tributos calculados com base na renda das pessoas física ou jurídica;

- 2000 - Tributos sobre a Folha de Salários: Esta categoria abrange os tributos que gravam diretamente a folha de salários, independente da destinação de sua arrecadação; 
- 3000 - Tributos sobre a Propriedade: Tributos que incidam sobre o uso, propriedade ou transferência de bens móveis e imóveis, tanto de pessoas físicas como de pessoas jurídicas. Não se incluem nesta categoria os impostos sobre o ganho de capital decorrente da alienação de bens móveis e imóveis, os quais devem ser computados na categoria 1000 - Tributos sobre a Renda;

- 4000 - Tributos sobre Bens e Serviços: Tributos aplicados sobre a alienação, transferência, produção de bens ou prestação de serviços. Esta categoria compreende os tributos monofásicos ou multifásicos, os tributos sobre a receita ou faturamento aplicados em qualquer fase da cadeia produtiva, os tributos sobre o valor agregado, os tributos seletivos e os tributos aplicados ao comércio exterior;

- 5000 - Tributos sobre Transações Financeiras: Tributos que incidem sobre operações financeiras de toda natureza. Incluem-se nesta categoria os tributos sobre débitos e créditos bancários ${ }^{3}$, sobre compra e venda de moedas estrangeiras, sobre emissão, transferência, compra e venda de títulos e valores mobiliários, sobre operações de crédito, dentre outros;

- 9000 - Outros Tributos: Compreendem os tributos que incidem em bases distintas daquelas descritas nas categorias 1000, 2000, 3000, 4000 e 5000 ou que não possam ser considerados como predominantemente pertencentes a uma dessas categorias. Caso um tributo incida em mais de uma base e seja possível desagregar a arrecadação segundo cada uma delas, as parcelas de receitas foram apropriadas segundo a base correspondente. Caso não seja possível e não haja predominância de determinada base, a arrecadação integral foi alocada nesta categoria. (RFB, 2017, pp. 44-51)

Desta maneira, de posse das classificações tributárias, passemos aos estudos sobre a representatividade que cada base de incidência exerce sobre a arrecadação brasileira, conforme exposto no Quadro 05.

Quadro 5 - Carga Tributária e Variacão por Base de Incidência, (2015 e 2016)

\begin{tabular}{|c|c|c|c|c|c|c|c|}
\hline \multirow[b]{2}{*}{ Código } & \multirow{2}{*}{$\begin{array}{l}\text { Tipo de } \\
\text { Base }\end{array}$} & \multicolumn{3}{|c|}{2015} & \multicolumn{3}{|c|}{2016} \\
\hline & & Arrecadação - R\$ Milhões & $\%$ PIB & \% da Arrecadação & Arrecadação - R\$ Milhões & $\%$ PIB & \% da Arrecadação \\
\hline$\cdot$ & Total & $1.925 .451,14$ & $32,11 \%$ & $100,00 \%$ & \begin{tabular}{|l|}
$2.027 .014,48$ \\
\end{tabular} & $32,38 \%$ & $100 \%$ \\
\hline 1000 & Renda & $352.368,74$ & $5,88 \%$ & $18,30 \%$ & $404.817,40$ & $6,47 \%$ & $19,97 \%$ \\
\hline 2000 & Folha de Salários & $502.676,82$ & $8,38 \%$ & $26,11 \%$ & $533.235,87$ & $8,52 \%$ & $26,31 \%$ \\
\hline 3000 & Propriedade & $85.572,80$ & $1,43 \%$ & $4,44 \%$ & $94.602,37$ & $1,51 \%$ & $4,67 \%$ \\
\hline 4000 & Bens e Serviços & $950.610,78$ & $15,85 \%$ & $49,37 \%$ & $960.556,63$ & $15,35 \%$ & $47,39 \%$ \\
\hline 5000 & Transações Financeiras & $34.686,30$ & $0,58 \%$ & $1,80 \%$ & $33.644,91$ & $0,54 \%$ & $1,66 \%$ \\
\hline 9000 & Outros & $-464,30$ & $-0,01 \%$ & $-0,02 \%$ & 157,30 & $0,00 \%$ & $0,01 \%$ \\
\hline
\end{tabular}

Ao analisarmos os valores arrecadados é possível constatar que, dentre as seis bases de incidência, Bens e Serviços se caracteriza como a principal fonte de recolhimento fiscal.

\footnotetext{
${ }^{3}$ Antiga CPMF (Contribuição Provisória sobre Movimentação ou Transmissão de Valores e de Créditos e Direitos de Natureza Financeira). Mesmo que extinta no ano de 2007, ainda consta na base de constituição de Transações Financeiras.
} 
Tanto no ano de 2015 quanto no de 2016 essa base foi responsável por quase 50\% de todo o montante tributário destinado para os cofres públicos. Em termos monetários, aproximadamente $\mathrm{R} \$ 1$ trilhão foram transferidos para a Fazenda por intermédio deste instrumental e, em média, $15,6 \%$ do PIB.

As demais cinco categorias foram responsáveis pelo recolhimento dos $50 \%$ restantes e, em ordem de relevância, são: Folha de Salários, Renda, Propriedade, Transações Financeiras e Outros. O Gráfico 02 nos auxilia na visualização da arrecadação percentual de cada uma das bases de incidência, elencando-as em ordem crescente:

\section{Gráfico 2 - Participacão das Bases de Incidência na Arrecadacão Total, (2016)}

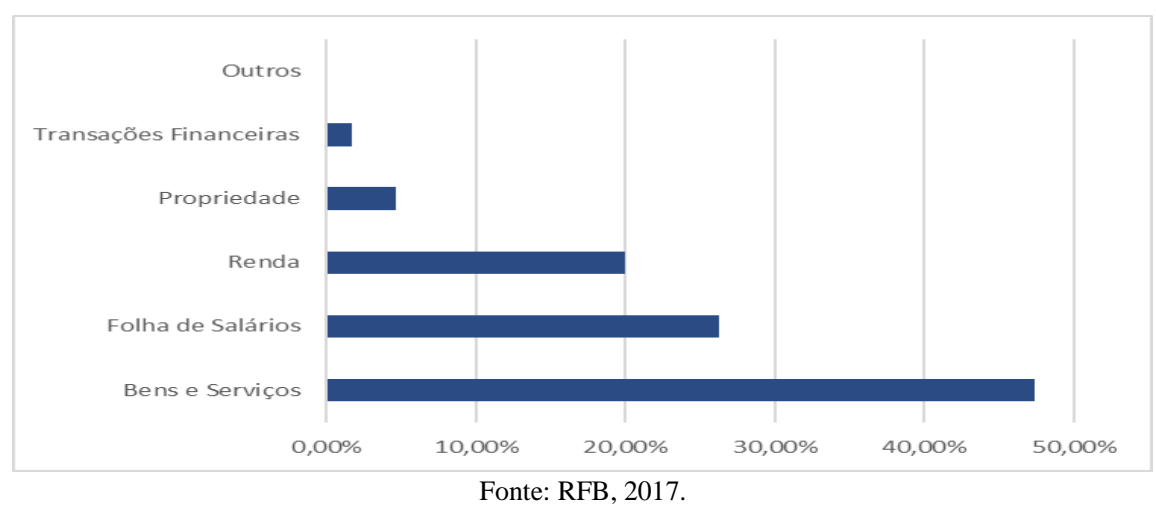

Desta maneira, podemos questionar: esse comportamento da arrecadação com Bens $e$ Serviços é algo atípico ou estamos diante da regra? A fim de responder tal questão, apresentamos o Gráfico 03.

\section{Gráfico 3 - Série Histórica da Participação de Bens e Serviços na Arrecadacão Total, (2007 a 2016)}

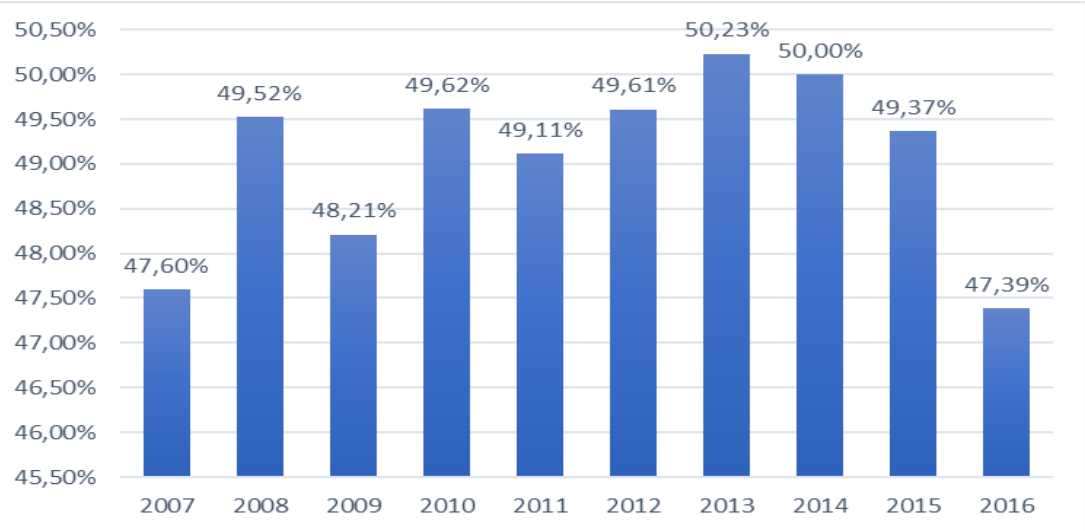

Fonte: RFB, 2017. 
Por meio do Gráfico 03 é possível verificar que na última década a categoria analisada foi responsável por, em média, $49 \%$ da arrecadação total. Ou seja, o lugar de vanguarda no período em pauta sempre foi ocupado por Bens e Serviços. Mesmo em anos de recessão econômica observamos que esta categoria tributária não deixou de ocupar o posto de principal fonte de recolhimento. Por mais que haja diminuição nos percentuais de arrecadação, tais declínios são tímidos. Entretanto, em termos monetários manteve-se praticamente instável, inclusive, com leve aumento. Em 2015 foram recolhidos aproximadamente R\$ 950.610 milhões, no ano de 2016 R\$ 960.556 milhões ${ }^{4}$.

Todavia, o contexto econômico brasileiro não apresentou o mesmo cenário de tranquilidade. De acordo com indicadores econômicos consolidados, divulgados pelo Banco Central do Brasil, o biênio 2015 - 2016 sofreu acentuada contração econômica, de 3,5\% do Produto Interno Bruto. A taxa média de desocupação alcançou, no final de 2016, $12 \%$ da população economicamente ativa e o IPCA, índice de inflação oficial, registrou em 2015 elevação de 10,67\%.

Conforme apresentamos anteriormente, os dados arrecadatórios não foram impactados por tal conjuntura econômica. O Gráfico 01 demonstra que o comportamento da carga tributária brasileira apresenta, em média, os mesmos percentuais de arrecadação desde o início do século XXI. Diante desta constatação, cabe a observação da série histórica por base de incidência. O Quadro 06 permite que efetuemos esta análise.

\section{Quadro 6 - Evolução da Participacão das Bases de Incidência na Arrecadacão Total, (2007 a 2016)}

\begin{tabular}{|c|c|c|c|c|c|c|c|c|c|c|c|}
\hline Código & Tipo de Base & 2007 & 2008 & 2009 & 2010 & 2011 & 2012 & 2013 & 2014 & 2015 & 2016 \\
\hline $\mathbf{4 0 0 0}$ & Bens e Serviços & $47,60 \%$ & $49,52 \%$ & $48,21 \%$ & $49,62 \%$ & $49,11 \%$ & $49,61 \%$ & $50,23 \%$ & $50,00 \%$ & $49,37 \%$ & $47,39 \%$ \\
\hline $\mathbf{2 0 0 0}$ & Folha de Salários & $24,55 \%$ & $24,54 \%$ & $26,01 \%$ & $26,21 \%$ & $25,55 \%$ & $26,66 \%$ & $25,99 \%$ & $26,20 \%$ & $26,11 \%$ & $26,31 \%$ \\
\hline $\mathbf{1 0 0 0}$ & Renda & $19,30 \%$ & $20,45 \%$ & $19,63 \%$ & $18,22 \%$ & $19,09 \%$ & $17,93 \%$ & $18,16 \%$ & $18,07 \%$ & $18,30 \%$ & $19,97 \%$ \\
\hline $\mathbf{3 0 0 0}$ & Propriedade & $3,54 \%$ & $3,55 \%$ & $3,89 \%$ & $3,77 \%$ & $3,73 \%$ & $3,77 \%$ & $3,90 \%$ & $4,09 \%$ & $4,44 \%$ & $4,67 \%$ \\
\hline $\mathbf{5 0 0 0}$ & Transações Financeiras & $4,82 \%$ & $2,03 \%$ & $1,79 \%$ & $2,10 \%$ & $2,20 \%$ & $1,96 \%$ & $1,68 \%$ & $1,62 \%$ & $1,80 \%$ & $1,66 \%$ \\
\hline $\mathbf{9 0 0 0}$ & 0utros & $0,18 \%$ & $-0,09 \%$ & $-0,12 \%$ & $0,08 \%$ & $0,03 \%$ & $-0,03 \%$ & $0,03 \%$ & $0,01 \%$ & $-0,02 \%$ & $0,01 \%$ \\
\hline
\end{tabular}

Mesmo ocorrendo pequenas elevações ou quedas dos recolhimentos dentre as categorias de incidência, a representatividade de cada instrumental não sofreu alteração diante do

\footnotetext{
${ }^{4}$ Os dados apresentados são nominais.
} 
todo. A base Bens e Serviços, como já exposto, é a principal fonte de arrecadação do governo brasileiro, sendo responsável pelo recolhimento de quase $50 \%$ do montante destinado aos cofres públicos. Na sequência temos Folha de Salários, contribuindo com aproximadamente $25 \%$ da arrecadação total. A categoria Renda ocupa o terceiro lugar na ordem de importância, incumbida por transferir ao Tesouro $20 \%$ dos valores angariados. As bases de incidência de menor representatividade são Propriedade, Transações Financeiras e Outros, que juntas somam aproximados 5\% do recolhimento fiscal. Dando prosseguimento ao estudo, adiante apresentaremos a discussão sobre como a competência tributária está dividida entre os entes federativos.

\section{A competência tributária dos entes federativos: Nação, Estados e Municípios}

Até o momento nos ocupamos em apresentar os dados de arrecadação agregados e por base de incidência. Entretanto, não houve uma análise sobre a representatividade arrecadatória de cada categoria tributária perante os cofres federal, estadual e municipal. Somado a este fato, se faz necessário o estudo sobre a representatividade individual de cada tributo diante da arrecadação total. Os conhecimentos desta repartição de competências tributárias auxiliam na compreensão sobre as discussões relacionadas à estrutura tributária atual, os possíveis desdobramentos que futuras reformas tributárias trariam e os impactos para cada ente federativo.

\section{Quadro 7 - Carga Tributária por Ente Federativo, (2015 e 2016)}

\begin{tabular}{|c|c|c|c|c|c|c|}
\hline \multirow{2}{*}{$\begin{array}{l}\text { Entidade } \\
\text { Federativa }\end{array}$} & \multicolumn{3}{|c|}{2015} & \multicolumn{3}{|c|}{2016} \\
\hline & Arrecadação - R\$ Millões & $\%$ PIB & \% da Arrecadação & Amrecadação - R\$ Millões & $\%$ PIB & \% da Arrecadaçãa \\
\hline União & $1.316 .253,83$ & $21,95 \%$ & $68,36 \%$ & $1.383 .758,72$ & $22,11 \%$ & $68,27 \%$ \\
\hline Estados & $489.263,46$ & $8,16 \%$ & $25,41 \%$ & $514.841,11$ & $8,33 \%$ & $25,40 \%$ \\
\hline Municipios & $119,933,85$ & $2,00 \%$ & $6,33 \%$ & $128.414,66$ & $2,05 \%$ & $6,34 \%$ \\
\hline
\end{tabular}

Os números apresentados no Quadro 07 auxiliam no entendimento sobre como é efetuada a divisão do recolhimento tributário entre União, Estados e Municípios. Nos dois anos considerados, pouco mais de $68 \%$ do valor arrecadado foi promovido pela esfera federal. Aos Estados coube a participação pouco superior a 25\% do recolhimento tributário. Para os Municípios foi destinada uma parcela de aproximadamente $6 \%$. 
Sendo assim, por meio dos dados apresentados torna-se evidente a constatação do quanto o direito de arrecadação da receita tributária brasileira é mal distribuído entre as três esferas governamentais. Enquanto a União promoveu um recolhimento de aproximadamente $22 \%$ do PIB, aos pouco mais de 5 mil Municípios brasileiros foi designada a fração de $2 \%$ do PIB. Os 26 Estados e Distrito Federal arrecadaram cerca de 8\% do PIB nacional. Em termos monetários a discrepância na arrecadação da receita também é notada. Enquanto a Nação recolheu aproximados R $\$ 1.3$ bilhões e os Estados $\mathrm{R} \$ 515$ bilhões, os Municípios concretizaram o montante fiscal de quase $\mathrm{R} \$ 130$ bilhões no ano de 2016.

Contudo, necessitamos salientar que os dados apresentados se referem ao direito que cada ente federativo possui no recolhimento tributário, ou seja, a competência tributária. As informações divulgadas no relatório disponibilizado pela Receita Federal do Brasil não consideram os repasses de verbas e a repartição de receitas existente entre os entes, repasses esses estabelecidos na Constituição Federal:

(...) o texto fundamental estatui, por exemplo, pertencer aos Estados e ao Distrito Federal o produto da arrecadação do imposto da União sobre a renda e proventos de qualquer natureza, incidente na fonte, sobre rendimentos pagos, a qualquer título, por eles, suas autarquias e pelas fundações que instituírem e mantiverem (art. 157, I). Também declara pertencer aos Municípios: a) o produto da arrecadação do imposto da União sobre renda e proventos de qualquer natureza, incidente na fonte, sobre rendimentos pagos, a qualquer título, por eles, suas autarquias e pelas fundações que instituírem e mantiverem; b) cinquenta por cento do produto da arrecadação do imposto da União sobre a propriedade territorial rural, relativamente aos imóveis neles situados, cabendo a totalidade na hipótese da opção a que se refere o art. $153, \S 4^{\circ}$, III; c) cinquenta por cento do produto da arrecadação do imposto do Estado sobre a propriedade de veículos automotores licenciados em seus territórios; d) vinte e cinco por cento do produto da arrecadação do imposto do Estado sobre operações relativas à circulação de mercadorias e sobre prestações de serviços de transporte interestadual e intermunicipal e de comunicação (art. 158, I a IV). (COSTA, 2016, p. 62)

Deste modo, as análises ora efetuadas mantiveram a fidelidade ao documento divulgado pela Receita Federal do Brasil e não levaram em consideração os repasses financeiros existentes entre os entes da federação.

Para melhor compreendermos a realidade tributária brasileira atual, passemos à análise da participação de cada ente federativo frente às categorias de incidência. Com base nos dados apresentados no Quadro 08, Quadro 09 e Quadro 10 é possível observar que, enquanto a União possui participação nas seis bases de incidência existentes, aos Estados 
e Municípios cabe a participação no recolhimento de somente três categorias: Folha de Salários, Propriedade e Bens e Serviços.

\section{Quadro 8 - Receita Tributária Federal por Base de Incidência, (2016)}

\begin{tabular}{|c|c|c|c|}
\hline \multirow{2}{*}{ Tipo de Base de Incidência } & \multicolumn{3}{|c|}{ Federal } \\
\cline { 2 - 4 } Tributos sobre a Renda & $404.817,40$ & $6,47 \%$ & Arrecadação - R\$ Milhões \\
\hline TIB & da Arre cadação \\
\hline Tributos sobre a Folha de Salários & $499.869,19$ & $7,99 \%$ & $93,74 \%$ \\
\hline Tributos sobre a Propriedade & $1.126,42$ & $0,02 \%$ & $1,19 \%$ \\
\hline Tributos sobre Bens e Serviços & $444.143,50$ & $7,10 \%$ & $46,24 \%$ \\
\hline Tributos sobre Transações Financeiras & $33.644,72$ & $0,54 \%$ & $100 \%$ \\
\hline Outros Tributos & 157,3 & $0,00 \%$ & $100 \%$ \\
\hline
\end{tabular}

Fonte: RFB, 2017.

Por meio do Quadro 08 temos clareza sobre a participação da competência federal diante de cada base de incidência. A União efetua o recolhimento de $100 \%$ dos valores provenientes dos tributos sobre a Renda e aproximados $94 \%$ dos tributos sobre a Folha de Salário, sendo esta, em termos monetários, a principal fonte de recursos do governo federal. Ao analisarmos a base Bens e Serviços, verificamos que esta categoria representa a segunda principal fonte de receitas da União. Além disso, a arrecadação federal dispõe integralmente das cifras adquiridas por meio das bases de incidência Transações Financeiras e Outros.

Quadro 9 - Receita Tributária Estadual por Base de Incidência, (2016)

\begin{tabular}{|c|c|c|c|}
\hline \multirow{2}{*}{ Tipo de Base de Incidência } & \multicolumn{3}{|c|}{ Estadual } \\
\cline { 2 - 4 } Tributos sobre a Renda & Arrecadação - R\$ Milhões & \% PIB & \% da Arrecadação \\
\hline Tributos sobre a Folha de Salários & - & - & - \\
\hline Tributos sobre a Propriedade & $23.248,33$ & $0,37 \%$ & $4,36 \%$ \\
\hline Tributos sobre Bens e Serviços & $46.275,01$ & $0,74 \%$ & $48,92 \%$ \\
\hline Tributos sobre Transações Financeiras & $445.317,78$ & $7,11 \%$ & $46,36 \%$ \\
\hline Outros Tributos & - & - & - \\
\hline \multicolumn{2}{|c|}{ Fonte: RFB, 2017. }
\end{tabular}

A receita tributária estadual, ilustrada no Quadro 09, faz jus a 46,36\% do montante gerado por Bens e Serviços, sendo essa a mais importante categoria de incidência para os cofres estaduais. Comparando-se a parcela de Bens e Serviços compartilhada entre União e Estados, verificamos que o montante direcionado a ambos é similar, enquanto este recebe R \$ 445.317 milhões, aquela é destinatária de R \$ 444.143 milhões. 


\section{Quadro 10 - Receita Tributária Municipal por Base de Incidência, (2016)}

\begin{tabular}{|c|c|c|c|}
\hline \multirow{2}{*}{ Tipo de Base de Incidência } & \multicolumn{3}{|c|}{ Municipal } \\
\cline { 2 - 4 } Tributos sobre a Renda & Arrecadação - R\$ Milhões & \% PIB & \% da Arrecadação \\
\hline Tributos sobre a Folha de Salários & - & - & - \\
\hline Tributos sobre a Propriedade & $10.118,36$ & $0,16 \%$ & $1,90 \%$ \\
\hline Tributos sobre Bens e Serviços & $47.200,95$ & $0,75 \%$ & $49,89 \%$ \\
\hline Tributos sobre Transações Financeiras & $71.095,35$ & $1,14 \%$ & $7,40 \%$ \\
\hline Outros Tributos & - & - & - \\
\hline
\end{tabular}

Fonte: RFB, 2017.

Os números referentes aos recolhimentos tributários municipais, expostos no Quadro 10, demonstram ser Bens e Serviços também a principal fonte de renda deste ente federativo. Desta maneira, temos Bens e Serviços como principal categoria arrecadatória dos Estados e Municípios, e a segunda principal fonte de renda da União.

Todavia, enquanto as arrecadações federal e estadual dispõem de aproximadamente $46 \%$ das cifras originadas por Bens e Serviços, aos Municípios são direcionados 7,4\%, resultando em $\mathrm{R} \$ 71.095$ milhões. A segunda categoria que mais contribui para os cofres municipais é Propriedade, com destinação de quase 50\% do montante arrecadado.

\section{Quadro 11 - Receita Tributária por Base de Incidência e Nível de Governo -} Análise Vertical, (2016)

\begin{tabular}{|c|c|c|c|c|}
\hline Tipo de Base de Incidência & Federal & Estadual & Municipal & Total \\
\hline Total da Receita Tributária & $\mathbf{1 0 0 \%}$ & $\mathbf{1 0 0 \%}$ & $\mathbf{1 0 0 \%}$ & $\mathbf{1 0 0 \%}$ \\
\hline Tributos sobre a Renda & $29,25 \%$ & - & - & $19,97 \%$ \\
\hline Tributos sobre a Folha de Salários & $36,12 \%$ & $4,52 \%$ & $7,88 \%$ & $26,31 \%$ \\
\hline Tributos sobre a Propriedade & $0,08 \%$ & $8,99 \%$ & $36,76 \%$ & $4,67 \%$ \\
\hline Tributos sobre Bens e Serviços & $32,10 \%$ & $86,50 \%$ & $55,36 \%$ & $47,39 \%$ \\
\hline Tributos sobre Transações Financeiras & $2,43 \%$ & - & - & $1,66 \%$ \\
\hline Outros Tributos & $0,01 \%$ & - & - & $0,01 \%$ \\
\hline
\end{tabular}

A importância de cada base de incidência perante as arrecadações das três esferas de poder fica mais evidente ao efetuarmos a análise vertical, apresentada no Quadro 11. A categoria Folha de Salário contribui com $36,12 \%$ dos valores arrecadados para a Fazenda Nacional, Bens e Serviços contribui com 32,1\%. Os tributos sobre a Renda são a terceira principal fonte de recolhimento da União, auxiliando com 29,25\% da arrecadação. Desta forma, temos as três principais fontes de recursos para o Tesouro Nacional, tendo as demais bases de incidência uma contribuição quase ínfima diante do todo. 
As considerações relacionadas às cifras estaduais são expressivas, pois verificamos a representatividade de mais de $86 \%$ de Bens e Serviços para seus cofres. Sendo assim, por intermédio dos números apresentados no Quadro 11 é possível constatar que os Estados são o ente federativo que possuem maior concentração de receitas em uma única fonte tributária.

Ademais, mesmo que em proporção menor, também se torna evidente a importância de Bens e Serviços para os cofres municipais. Para esta esfera governamental, tal categoria tributária representa mais de 55\% do montante arrecadado. Ou seja, mesmo que a divisão de Bens e Serviços entre os três entes federativos ocorra de maneira desproporcional para os Municípios, com uma participação de apenas 7,4\%, esta base de incidência é aquela que mais recursos lhes gera.

Diante deste contexto, fica explícita a dependência e vulnerabilidade que Bens e Serviços exercem sobre os cofres federal, estadual e municipal, conforme ilustrado no Gráfico 04. Ao menor movimento de queda no consumo brasileiro a arrecadação sofrerá severas restrições, gerando impactos e desequilíbrios financeiros que não podem ser ignorados.

\section{Gráfico 4 - Representatividade de Bens e Servicos na Arrecadacão - Análise Vertical, (2016)}

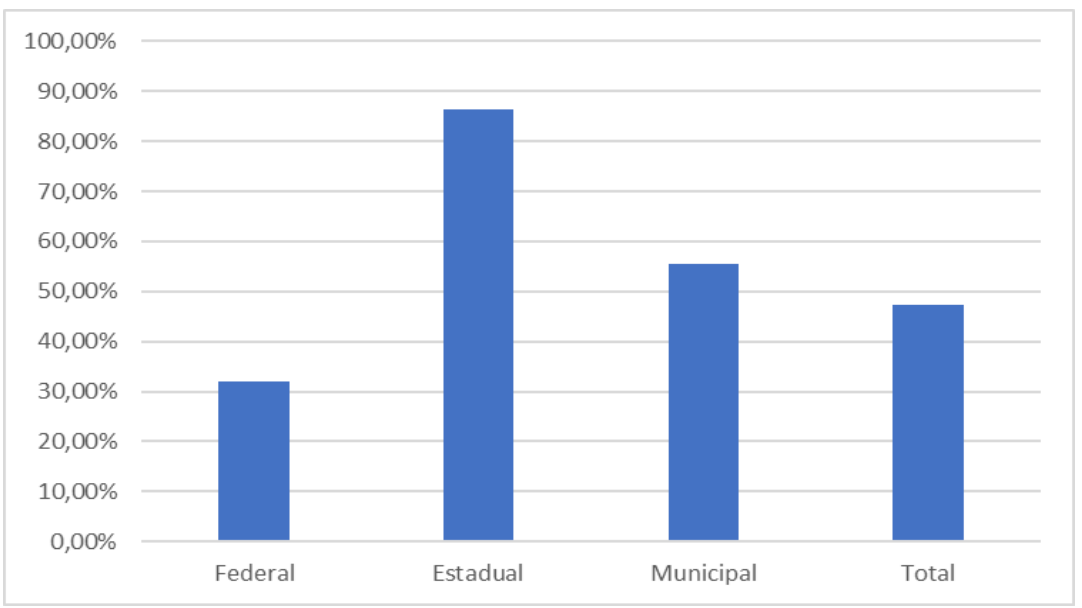

Fonte: RFB, 2017.

Diante dos dados apresentados até o momento foi possível analisar a importância de Bens e Serviços para a arrecadação total, bem como sua representatividade para cada ente federativo. Ademais, tornou-se evidente a dependência que os cofres públicos brasileiros possuem com a arrecadação oriunda do consumo. 
Contudo, as informações discutidas até o momento pouco esclarecem acerca da importância individual que cada tributo exerce perante a arrecadação fiscal como um todo. Para entendermos esta questão, serão apresentados no Quadro 12 os dez tributos mais expressivos em termos de arrecadação financeira; no Quadro 13 a importância arrecadatória do décimo primeiro ao vigésimo tributo; e no Quadro 14 o vigésimo primeiro em diante.

Quadro 12 - Receita Tributária por Relevância do Tributo: $1^{\circ}$ ao $10^{\circ}$, (2015 e 2016)

\begin{tabular}{|c|c|c|c|c|c|c|c|}
\hline & \multirow[b]{2}{*}{ Thioloto } & \multicolumn{3}{|c|}{20115} & \multicolumn{3}{|c|}{2016} \\
\hline & & 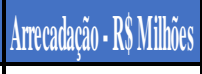 & g, PBB & 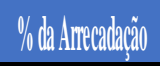 & 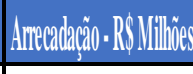 & \% PIB & 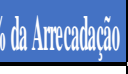 \\
\hline & 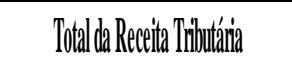 & 19:5:5it,1, & $3.111 \%$ & $100 \%$ & 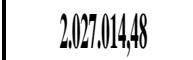 & $3,398 \%$ & 10\%\% \\
\hline 1 & ICUS & $366 ; 13,09$ & $6,11 \%$ & $20,09 \%$ & 412856,99 & $6,00 \%$ & $20,37 \%$ \\
\hline 2 & mpossodoctRenda & $341,64,79$ & $5,10 \%$ & $17,6 \%$ & $366.89,13$ & $6,18 \%$ & $19,98 \%$ \\
\hline 3 & 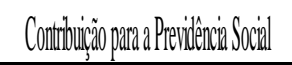 & $300,47,0$ & $5,344 \%$ & 16,6946 & $350.028,12$ & $5,35 \%$ & $16,53 \%$ \\
\hline 4 & Cofms & $199,86,00$ & $3,33 \%$ & $10,38 \%$ & 201517,28 & $3,22 \%$ & 0,914 \\
\hline$j$ & 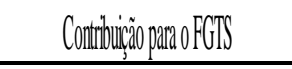 & $118,32,34$ & $1,97 \%$ & $6,15 \%$ & 124713,45 & $1,99 \%$ & $6,15 \%$ \\
\hline 6 & 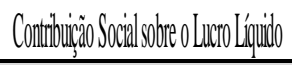 & $59.146,99$ & $0,99 \%$ & $3,07 \%$ & $6.759,99$ & $1,07 \%$ & $3,20 \%$ \\
\hline 1 & ISS & 54800,0 & $0,11 \%$ & $2.8 \% \%$ & 54622,10 & $0,87 \%$ & $2,69 \%$ \\
\hline 8 & 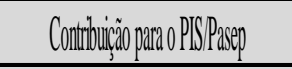 & 52599,66 & $0,89 \%$ & 2,730 & 52834,19 & 0,847 & $261 \%$ \\
\hline 9 & 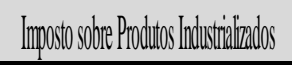 & $48.48,11$ & $0,00 \%$ & $250 \%$ & $4.851,41$ & $0,67 \%$ & $2,60 \%$ \\
\hline 10 & 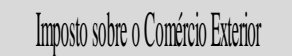 & 38960,36 & $0,5 \% \%$ & $200 \%$ & 31:47,61 & $0,00 \%$ & $1,55 \%$ \\
\hline
\end{tabular}

Quadro 13 - Receita Tributária por Relevância do Tributo: $11^{\circ}$ ao $20^{\circ}$, $\underline{(2015 \text { e 2016) }}$

\begin{tabular}{|c|c|c|c|c|c|c|c|}
\hline & \multirow[b]{2}{*}{ Tithitio } & \multicolumn{3}{|c|}{2015} & \multicolumn{3}{|c|}{2016} \\
\hline & & 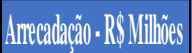 & \%PPB & Yo da Ameradactäo & 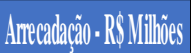 & $q_{P} P B$ & 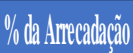 \\
\hline 11 & PVA & $36.218,71$ & $0,00 \%$ & $1,88 \%$ & $39,012,55$ & $0,62 \%$ & $1,92 \%$ \\
\hline 12 & 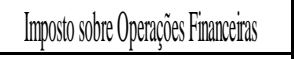 & $34.681,05$ & $0,58 \%$ & $1,80 \%$ & $33.64,72$ & $0,54 \%$ & $1,66 \%$ \\
\hline 13 & PTU & $31,60,02$ & $0,53 \%$ & $1,65 \%$ & $37.561,70$ & $0,00 \%$ & $1,85 \%$ \\
\hline 14 & 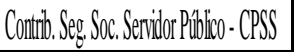 & 29339,60 & $0,49 \%$ & $1,5 \%$ & $30.691,15$ & $0,49 \%$ & $1,51 \%$ \\
\hline 15 & Outros Tinoturos Estaduais & 28977,91 & $0,48 \%$ & $1,50 \%$ & $32,460,79$ & $0,52 \%$ & $1,60 \%$ \\
\hline 16 & 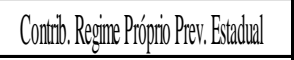 & $21,093,07$ & $0,35 \%$ & $1,10 \%$ & 232488,33 & $0,37 \%$ & $1,15 \%$ \\
\hline 17 & Salário Edaccaça & $19,038,91$ & $0,32 \%$ & $0,99 \%$ & $19,473,11$ & $0,31 \%$ & $0,96 \%$ \\
\hline 18 & 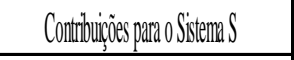 & $18.153,27$ & $0,30 \%$ & $0,94 \%$ & $18,427,99$ & $0,29 \%$ & $0,91 \%$ \\
\hline 19 & Outros Tintutoss Muncipais & $14,054,13$ & $0,33 \%$ & $0,73 \%$ & $16,73,25$ & $0,26 \%$ & $0,81 \%$ \\
\hline 20 & $\mid[B B \mid$ & $10,097,61$ & $0,17 \%$ & $0,5 \%$ & $9.639,25$ & $0,15 \%$ & $0,48 \%$ \\
\hline
\end{tabular}




\section{Quadro 14 - Receita Tributária por Relevância do Tributo: $21^{\circ}$ ao $37^{\circ}$, $\underline{(2015 \text { e 2016) }}$}

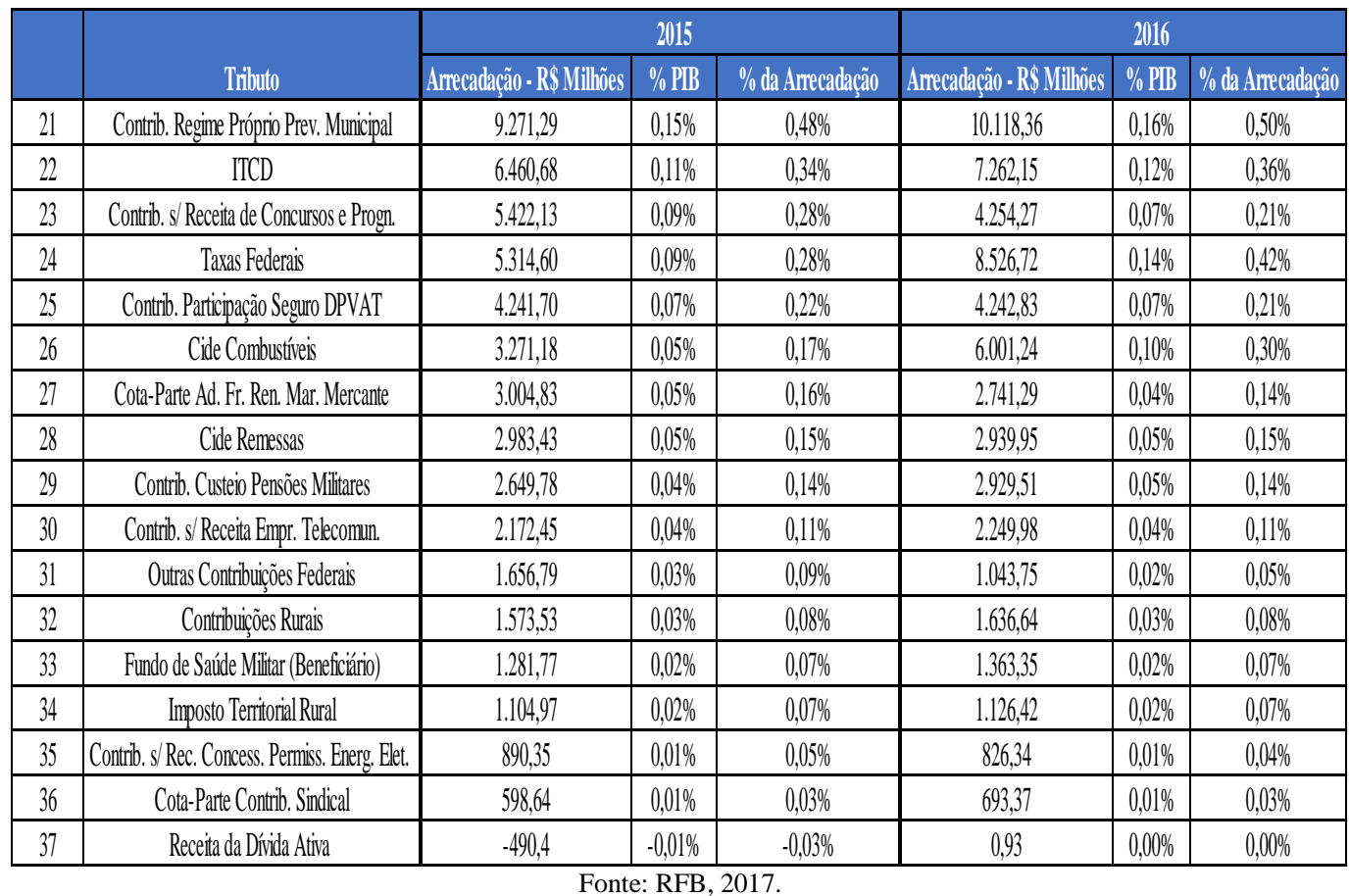

Antes de adentrarmos a discussão sobre os números apresentados nos Quadros 12, 13 e 14, torna-se essencial o esclarecimento sobre os tributos que compõem a base Bens $e$ Serviços:

\section{- Tributos Federais:}

A) Imposto sobre Produtos Industrializados - IPI;

B) Contribuição para o Programa de Integração Social e o Programa de Formação do Patrimônio do Servidor Público - PIS/PASEP;

C) Contribuição para o Financiamento da Seguridade Social - COFINS;

D) Imposto de Importação e Imposto de Exportação (Imposto sobre Comércio Exterior) - II e $I E^{5}$.

- Tributos Estaduais:

A) Imposto sobre Operações Relativas à Circulação de Mercadorias e sobre Prestação de Serviços de Transporte Interestadual, Intermunicipal e de Comunicação - ICMS.

\footnotetext{
${ }^{5}$ Os impostos alfandegários foram inclusos na base de incidência Bens e Serviços no relatório do ano de 2017, referente à arrecadação financeira do ano calendário 2016.
} 


\section{- Tributos Municipais:}

A) Imposto sobre Serviço de Qualquer Natureza - ISS.

Os dados dos Quadros 12, 13 e 14 apresentam informações consideráveis relacionadas aos tributos mais representativos para os cofres brasileiros. Dentre as 37 fontes de receita elencadas, é possível verificar que os seis tributos que constituem Bens e Serviços estão entre as 10 principais ferramentas de arrecadação - Quadro 12. Além disso, o ICMS imposto estadual - arrecada sozinho aproximadamente $21 \%$ do total verificado. O ISS imposto municipal - é o sétimo tributo em importância arrecadatória. COFINS, PIS/PASEP, IPI e Imposto sobre o Comércio Exterior (II e IE) - tributos federais ocupam, respectivamente a $4^{\mathrm{a}}, 8^{\mathrm{a}}, 9^{\mathrm{a}}$ e $10^{\mathrm{a}}$ posições na importância arrecadatória brasileira. O Gráfico 05 apresenta o percentual de arrecadação dos dez tributos mais expressivos para o Erário.

\section{Gráfico 5 - Tributos por percentual de Arrecadacão, (2016)}

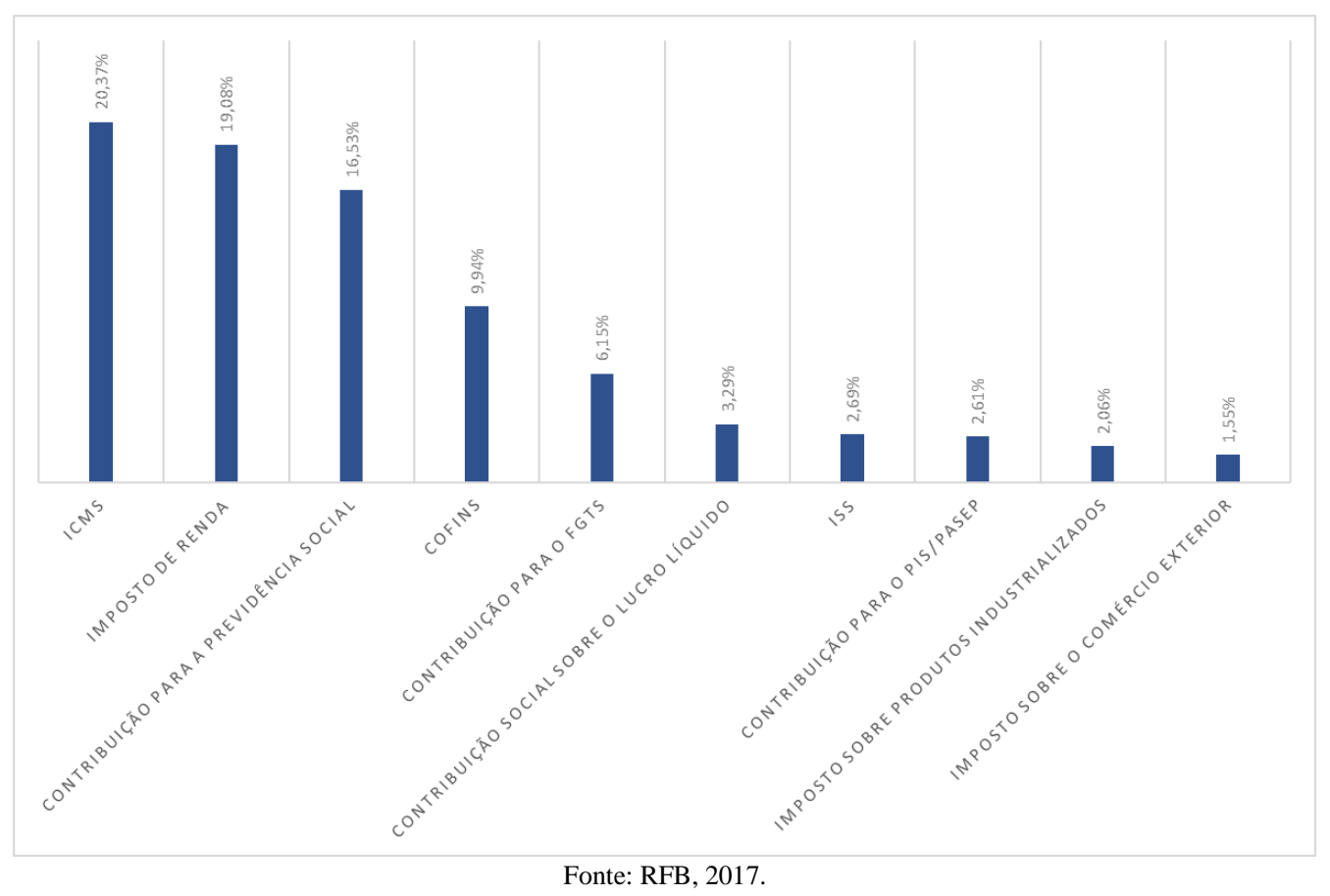

Deste modo, por meio dos dados divulgados pela Receita Federal do Brasil procuramos apresentar a composição da carga tributária brasileira atual. Analisamos os valores agregados, as comparações internacionais entre Brasil, países da América Latina e Caribe e países que constituem a OCDE. Verificamos as bases de incidência mais expressivas para a arrecadação total, bem como para cada ente federativo e, por fim, os tributos que transferem maiores somas de recursos para os cofres públicos. 
Além disso, constatamos quão expressiva é a categoria de incidência Bens e Serviços para as finanças das três esferas de poder e o quanto os tributos que a compõem são importantes para que o governo concretize a função fiscal tributária, uma vez que praticamente $50 \%$ do recolhimento provém desta base. No próximo tópico analisaremos os dados arrecadatórios do Estado de São Paulo.

\section{O ICMS no Estado de São Paulo}

As análises apresentadas até o momento revelam quais são as fontes de arrecadação mais importantes para o Tesouro nas três esferas de poder. Por meio do Quadro 12 foi possível constatar que dentre os dez tributos que maiores somas monetárias proporcionam, seis constituem a base de incidência Bens e Serviços.

Ademais, verificamos a expressividade que o ICMS possui para o recolhimento público, sendo este imposto o mais importante instrumental de transferência de recursos dos agentes particulares para a Fazenda. O Imposto sobre Circulação de Mercadorias e Serviços de Transporte Interestadual, Intermunicipal e de Comunicação foi responsável no ano de 2016, isoladamente, por quase $21 \%$ de toda a arrecadação, apropriando-se de pouco mais de 6,5\% do PIB nacional. A renda gerada pela receita do ICMS é recolhida pelos Estados e Distrito Federal. Desta maneira, são estes entes federativos os beneficiários diretos de tais recursos ${ }^{6}$.

Com o intuito de conhecermos a importância que o ICMS atribui à finança pública estadual, apresentaremos adiante os números referentes ao recolhimento tributário do Estado de São Paulo. Optamos pelo estudo deste Estado dada a sua representatividade econômica e populacional perante o Brasil. Além disso, como será demonstrado a seguir, São Paulo é responsável por aproximadamente $30 \%$ de todo o montante arrecadado com o ICMS no território brasileiro.

\footnotetext{
${ }^{6}$ Não estamos considerando os repasses que os Estados devem efetuar aos Municípios, mas sim o ente federativo que possui o direito do recolhimento do tributo. O artigo 158, da Constituição Federal de 1988, estabelece que $25 \%$ do produto de arrecadação do ICMS pertence aos Municípios.
} 
Os estudos apresentados adiante foram realizados de acordo com os dados extraídos do Relatório da Receita Tributária do Estado de São Paulo, elaborado pelo Governo de São Paulo, sob a tutela da Secretaria da Fazenda, Coordenadoria da Administração Tributária e Diretoria de Estudos Tributários e Econômicos. Por intermédio do Quadro 15 é possível aferir a arrecadação mensal do ICMS nos anos de 2015 e 2016, na esfera nacional ${ }^{7}$.

\section{Quadro 15 - Arrecadacão Mensal do ICMS no Brasil, (2015 e 2016)}

\begin{tabular}{|c|c|c|c|c|}
\hline \multirow{2}{*}{ Mês } & \multicolumn{2}{|c|}{ Valores mensais } & \multicolumn{2}{c|}{ Valores acumulados } \\
\cline { 2 - 5 } & $\mathbf{2 0 1 5}$ & $\mathbf{2 0 1 6}$ & $\mathbf{2 0 1 5}$ & $\mathbf{2 0 1 6}$ \\
\hline jan & $39.932,7$ & $38.045,0$ & $39.932,7$ & $38.045,0$ \\
\hline fev & $36.545,3$ & $34.802,5$ & $76.478,0$ & $72.847,5$ \\
\hline mar & $35.383,8$ & $34.964,0$ & $111.861,8$ & $107.811,5$ \\
\hline abr & $38.275,4$ & $35.622,0$ & $150.137,2$ & $143.433,5$ \\
\hline mai & $36.289,4$ & $34.975,0$ & $186.426,6$ & $178.408,5$ \\
\hline jun & $36.910,0$ & $34.719,5$ & $223.336,6$ & $213.128,0$ \\
\hline jul & $37.008,1$ & $34.586,2$ & $260.344,7$ & $247.714,2$ \\
\hline ago & $36.123,7$ & $34.886,0$ & $296.468,4$ & $282.600,2$ \\
\hline set & $38.130,7$ & $35.290,4$ & $334.599,1$ & $317.890,5$ \\
\hline out & $37.761,7$ & $35.029,4$ & $372.360,8$ & $352.919,9$ \\
\hline nov & $37.369,8$ & $36.423,8$ & $409.730,5$ & $389.343,7$ \\
\hline dez & $39.016,8$ & $37.683,7$ & $448.747,3$ & $427.027,5$ \\
\hline Total & $\mathbf{4 4 8 . 7 4 7 , 3}$ & $\mathbf{4 2 7 . 0 2 7 , 5}$ & & \\
\hline \multicolumn{5}{|l}{ Fonte: Secretaria da Fazenda do Estado de São Paulo, 2017 } \\
\hline
\end{tabular}

A apresentação dos números nacionais justifica-se pela necessidade em se mensurar a participação que a arrecadação paulista exerce sobre a arrecadação total com este imposto. O Quadro 16 apresenta os dados brasileiros, excluindo-se o ICMS recolhido no território paulista.

\footnotetext{
7 Os números apresentados pela Secretaria da Fazenda do Estado de São Paulo são divergentes dos números apresentados pela Receita Federal do Brasil. Além da diferença do período da coleta e divulgação dos dados, sendo o relatório da RFB divulgado em dezembro de 2017 e o relatório da Secretaria da Fazenda de São Paulo em fevereiro de 2017, as metodologias empregadas não convergem.
} 
Quadro 16 - Arrecadacão Mensal do ICMS: Brasil exceto São Paulo, (2015 e 2016)

\begin{tabular}{|c|c|c|c|c|}
\hline \multirow{2}{*}{ Mês } & Valores mensais & \multicolumn{2}{c|}{ Valores acumulados } \\
\cline { 2 - 5 } & $\mathbf{2 0 1 5}$ & $\mathbf{2 0 1 6}$ & $\mathbf{2 0 1 5}$ & $\mathbf{2 0 1 6}$ \\
& & & & \\
\hline jan & $27.950,7$ & $26.977,1$ & $27.950,7$ & $26.977,1$ \\
\hline fev & $24.799,1$ & $24.207,3$ & $52.749,9$ & $51.184,4$ \\
\hline mar & $23.834,6$ & $23.886,7$ & $76.584,4$ & $75.071,1$ \\
\hline abr & $26.248,6$ & $25.143,7$ & $102.833,0$ & $100.214,9$ \\
\hline mai & $25.063,8$ & $24.388,3$ & $127.896,8$ & $124.603,2$ \\
\hline jun & $25.133,8$ & $23.876,5$ & $153.030,7$ & $148.479,7$ \\
\hline jul & $25.328,2$ & $24.366,4$ & $178.358,8$ & $172.846,0$ \\
\hline ago & $24.936,9$ & $24.307,4$ & $203.295,8$ & $197.153,4$ \\
\hline set & $26.321,6$ & $24.808,1$ & $229.617,4$ & $221.961,5$ \\
\hline out & $25.985,2$ & $24.167,5$ & $255.602,6$ & $246.129,0$ \\
\hline nov & $26.012,0$ & $25.157,0$ & $281.614,7$ & $271.286,0$ \\
\hline dez & $26.264,9$ & $26.308,6$ & $307.879,6$ & $297.594,6$ \\
\hline Total & $\mathbf{3 0 7 . 8 7 9 , 6}$ & $\mathbf{2 9 7 . 5 9 4 , 6}$ & \multicolumn{1}{l}{} \\
\hline \multicolumn{5}{|c|}{ Fonte: Secretaria da Fazenda do Estado de São Paulo, 2017. } \\
\hline
\end{tabular}

Desta maneira, é possível averiguar que os valores arrecadados com o ICMS paulista oferecem uma representatividade de aproximadamente $30 \%$ do montante nacional, como ilustra o Quadro 17.

Quadro 17 - Arrecadacão Mensal do ICMS em São Paulo, (2015 e 2016)

\begin{tabular}{|c|c|c|c|c|}
\hline \multirow{2}{*}{ Mês } & \multicolumn{2}{|c|}{ Valores mensais } & \multicolumn{2}{c|}{ Valores acumulados } \\
\cline { 2 - 5 } & $\mathbf{2 0 1 5}$ & $\mathbf{2 0 1 6}$ & $\mathbf{2 0 1 5}$ & $\mathbf{2 0 1 6}$ \\
\hline jan & $11.982,0$ & $11.067,9$ & $11.982,0$ & $11.067,9$ \\
\hline fev & $11.746,1$ & $10.595,3$ & $23.728,1$ & $21.663,1$ \\
\hline mar & $11.549,2$ & $11.077,3$ & $35.277,3$ & $32.740,4$ \\
\hline abr & $12.026,8$ & $10.478,3$ & $47.304,2$ & $43.218,7$ \\
\hline mai & $11.225,6$ & $10.586,6$ & $58.529,8$ & $53.805,3$ \\
\hline jun & $11.776,2$ & $10.843,0$ & $70.305,9$ & $64.648,3$ \\
\hline jul & $11.679,9$ & $10.219,9$ & $81.985,8$ & $74.868,1$ \\
\hline ago & $11.186,8$ & $10.578,6$ & $93.172,6$ & $85.446,8$ \\
\hline set & $11.809,1$ & $10.482,3$ & $104.981,7$ & $95.929,0$ \\
\hline out & $11.776,5$ & $10.861,9$ & $116.758,2$ & $106.791,0$ \\
\hline nov & $11.357,7$ & $11.266,8$ & $128.115,9$ & $118.057,8$ \\
\hline dez & $12.751,8$ & $11.375,1$ & $140.867,7$ & $129.432,9$ \\
\hline Total & $\mathbf{1 4 0 . 8 6 7 , 7}$ & $\mathbf{1 2 9 . 4 3 2 , 9}$ & & \\
\hline
\end{tabular}

Participação de São Paulo no Brasil (\%)

Ano $2015 \quad 2016$

\begin{tabular}{ccc|} 
Média Anual & 31,4 & 30,3 \\
Fonte: Secretaria da Fazenda do Estado de São Paulo, 2017.
\end{tabular}


Adiante serão ilustrados os dados internos da arrecadação paulista com o ICMS e suas outras fontes de renda fiscal. Além disso, serão apresentados os setores da economia que mais contribuem para o recolhimento do ICMS em São Paulo, bem como as arrecadações de acordo com as regiões do Estado. Tais informações são relevantes a fim de se tornar possível o mapeamento da natureza econômica que proporciona a geração de recursos fiscais, por intermédio do ICMS, para o Estado.

\section{Gráfico 6 - Composicão da Receita Tributária no Estado de São Paulo, (2016)}

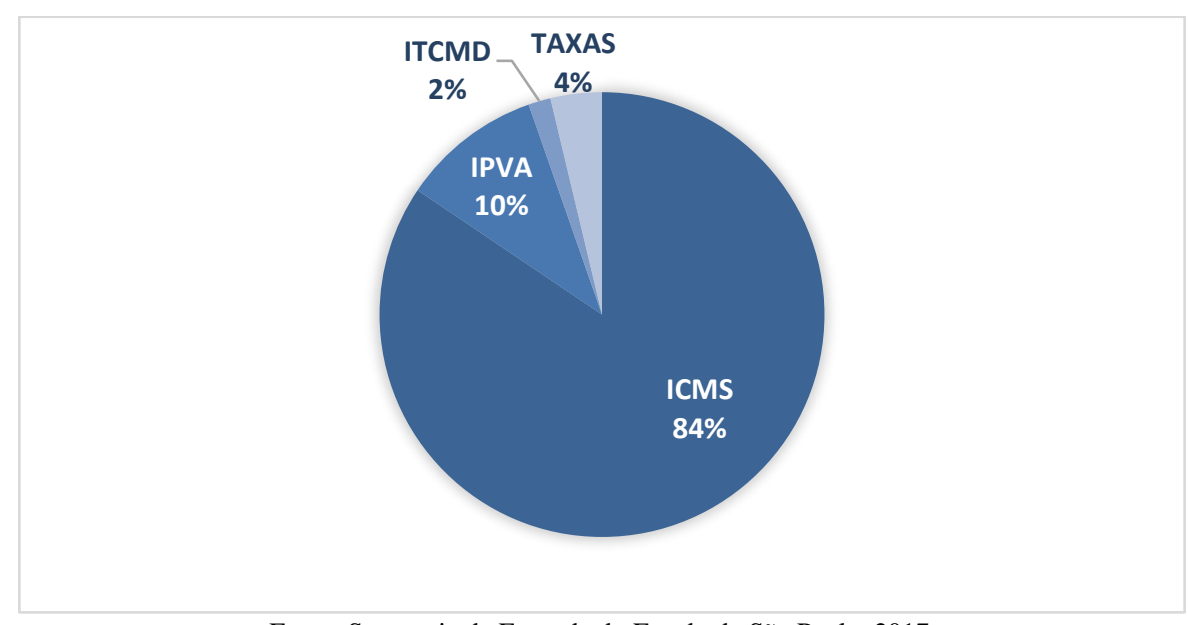

Fonte: Secretaria da Fazenda do Estado de São Paulo, 2017.

De acordo com os percentuais apresentados no Gráfico 06, observamos que no Estado paulista $84 \%$ da arrecadação é oriunda exclusivamente dos valores gerados pelo ICMS. Sendo assim, detectamos a forte concentração de receita e dependência que São Paulo possui nesta fonte de recurso tributário. Os responsáveis pelos demais $16 \%$ da arrecadação estadual estão divididos em 03 fontes de recolhimento, a saber:

A) $10 \%$ provenientes do Imposto sobre a Propriedade de Veículos Automotores IPVA;

B) $4 \%$ procedentes de Taxas Diversas, e;

C) $2 \%$ derivados do Imposto de Transmissão Causa Mortis e Doação - ITCMD.

Diante deste panorama, e da constatação da relevância que o ICMS possui para a Fazenda paulista, traçamos as arrecadações com este imposto por setor de atividade. Por meio deste levantamento procuramos entender quais são os setores econômicos que oferecem maior prosperidade e desenvolvimento para o Estado e suas finanças. 
Quadro 18 - Arrecadaç̃a de ICMS por Setor de Atividade, (2016)

\begin{tabular}{|c|c|c|c|}
\hline Setor & Total 2016 & Setor & Total 2016 \\
\hline COMÉRCIO E SERVIÇOS & $40.322,4$ & \multicolumn{2}{|c|}{ Continuação: INDÚSTRIA - Eletrodom. e Máq. Escritório } \\
\hline Comércio Atacadista & $24.355,2$ & Papel e celulose & $1.773,1$ \\
\hline Serviço de transporte & $2.541,7$ & Artigos de borracha & $1.014,9$ \\
\hline Revendedora de veículos & $3.027,8$ & Couros e calçados & 134,3 \\
\hline Loja de departamentos & 714,1 & Produtos químicos & $6.779,3$ \\
\hline Supermercados & $1.376,1$ & Produtos farmacêuticos & $3.069,7$ \\
\hline Comércio varejista - Outros & $5.845,6$ & Produtos de perfumaria e cosméticos & 728,3 \\
\hline Serviços - Outros & $2.461,8$ & Produtos de plástico & $1.872,0$ \\
\hline INDÚSTRIA & $40.153,7$ & Têxtil & 466,9 \\
\hline Indústria extrativa & 242,0 & Vestuário e acessórios & 502,8 \\
\hline Minerais não metálicos & $1.634,5$ & Produtos alimentícios & $4.079,4$ \\
\hline Metalúrgica & $2.792,4$ & Bebidas & $3.464,0$ \\
\hline Metalurgia básica - ferrosos & 734,6 & Edição, impressão e gravações & 257,4 \\
\hline Metalurgia básica - não ferrosos & 503,4 & Reciclagem & 20,5 \\
\hline Produtos de metal & $1.554,4$ & Diversas & 420,0 \\
\hline Máq., equip.e instalações & $2.393,5$ & PREÇOS ADMINISTRADOS & $37.384,2$ \\
\hline Máquinas e equipamentos & $1.825,9$ & NÃO CLASSIFICADOS & $4.227,5$ \\
\hline Equip.médicos, óticos, automa. e precisão & 567,6 & AGROPECUÁRIA & 274,6 \\
\hline Mat. Elétrico e de Comunicações & $3.326,2$ & Agricultura, pecuária e outros prods.animais & 274,6 \\
\hline Eletrodom. e Máq. Escritório & $\mathbf{1 . 3 6 7 , 8}$ & & \\
\hline Eletrodomésticos & 532,1 & & \\
\hline Máq. de escrit. e equip. de inform. & 835,7 & & \\
\hline Máquinas, aparelhos e materiais elétricos & $1.298,7$ & & \\
\hline Mat. Eletrôn. e equip. de comunicação & 659,7 & & \\
\hline Material de transporte & $4.858,1$ & & \\
\hline Madeira & 88,7 & & \\
\hline Móveis & 235,6 & & \\
\hline \multicolumn{3}{|l|}{ TOTAL DA ARRECADAÇÃO } & $122.362,5$ \\
\hline
\end{tabular}

De acordo com os dados apresentados no Quadro 18, constatamos que no Estado de São Paulo a atividade econômica Comércio e Serviços é a principal provedora de riquezas tributárias para o cofre paulista. Na sequência, observamos a Indústria como a segunda fonte geradora de recursos. O posto de terceiro lugar é ocupado por Preços Administrados. As atividades Não Classificadas e Agropecuária ocupam o quarto e quinto lugar de importância, respectivamente.

Desta maneira, dentre os cinco setores analisados, três são responsáveis por pouco mais de $96 \%$ do recolhimento fiscal advindo do ICMS. Ademais, interessante notar a existência do equilíbrio arrecadatório entre Comércio e Serviços, Indústria e Preços Administrados, sendo cada um provedor de aproximadamente $30 \%$ das cifras recolhidas, como demonstra o Gráfico 07. 


\section{Gráfico 7 - Arrecadação de ICMS por Setor de Atividade, (2016)}

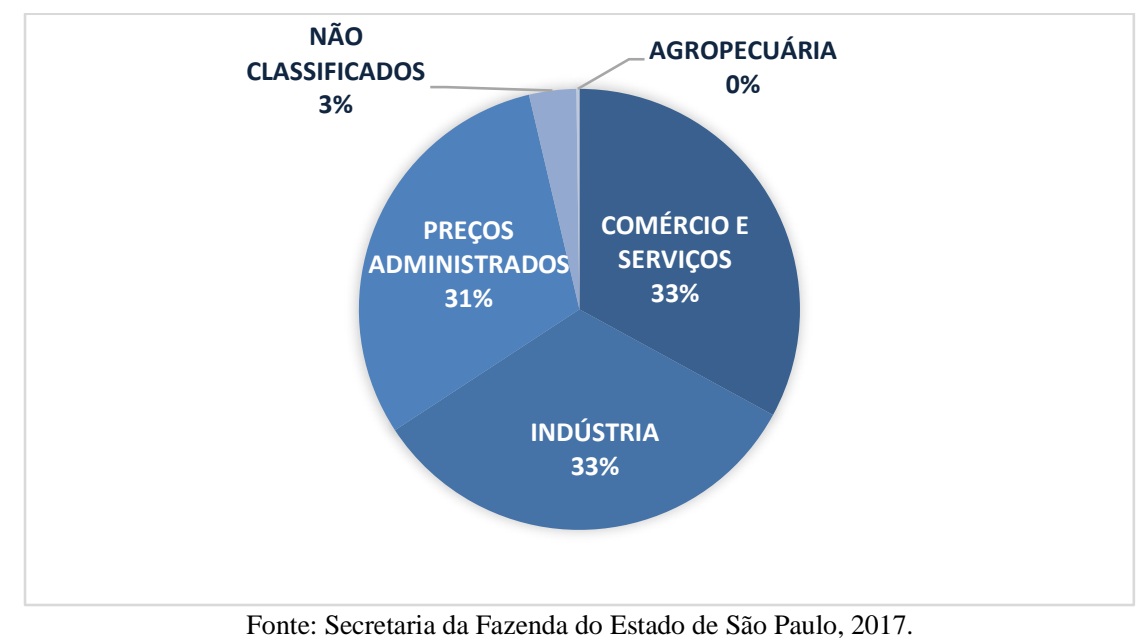

De posse destas informações é correto afirmar que, mesmo havendo a concentração de arrecadação pública no Imposto sobre Circulação de Mercadorias e Serviços, tal transferência de recursos financeiros da sociedade para o Estado ocorre em igualdade dentre os três setores econômicos de maior representatividade.

O esclarecimento sobre as atividades setoriais de maior magnitude para a economia paulista, ilustradas no Gráfico 07, nos remete ao questionamento acerca de quais são as regiões do Estado de São Paulo que mais favorecem a Fazenda Pública no tocante à obtenção de reservas provenientes do ICMS.

De acordo com a sistemática apresentada nos relatórios da Secretaria da Fazenda do Estado de São Paulo, o território está subdividido em 16 regiões. Mediante o Quadro 19 será ilustrada a arrecadação do ICMS, no ano de 2016, por região. O conhecimento destes dados nos permite verificar quais são as regiões que possuem maior destaque econômico e tributário no território paulista. 


\section{Quadro 19 - Arrecadação de ICMS por Região, (2016)}

Valores nominais em reais milhões e excluídos recolhimentos extraordinários de anistias.
\begin{tabular}{|l|c|}
\hline \multicolumn{1}{|c|}{ ICMS - Região } & Total/2016 \\
\hline DRT - CAPITAL & $41.936 .512,53$ \\
\hline DRT-05 - CAMPINAS & $15.052 .381,57$ \\
\hline DRT-14 - OSASCO & $14.507 .341,46$ \\
\hline DRT-16 - JUNDIAI & $8.727 .309,85$ \\
\hline DRT-13 - GUARULHOS & $6.081 .167,18$ \\
\hline DRT-12 - ABCD & $5.409 .393,20$ \\
\hline DRT-03 - TAUBATE & $4.636 .597,37$ \\
\hline DRT-04 - SOROCABA & $4.595 .738,59$ \\
\hline NÃO CLASSIFICADO & $4.323 .872,15$ \\
\hline DRT-06 - RIBEIRAO PRETO & $2.521 .957,11$ \\
\hline DRT-02 - LITORAL & $2.046 .823,15$ \\
\hline DRT-15 - ARARAQUARA & $1.981 .258,33$ \\
\hline DRT-07 - BAURU & $1.554 .416,79$ \\
\hline DRT-08 - SAO JOSE DO RIO PRETO & $1.095 .239,59$ \\
\hline DRT-11 - MARILIA & $858.279,49$ \\
\hline DRT-10 - PRESIDENTE PRUDENTE & $415.984,89$ \\
\hline DRT-09 - ARACATUBA & $407.231,47$ \\
\hline TOTAL & $122.362 .466,75$ \\
\hline
\end{tabular}

Fonte: Secretaria da Fazenda do Estado de São Paulo, 2017.

Os dados acima foram organizados de acordo com a relevância regional na arrecadação do ICMS. Desta maneira, fica evidente a representatividade que o Município de São Paulo oferece quanto à geração de recursos por meio desta fonte de receita, contribuindo com 36\% de todo o montante recolhido no Estado de São Paulo no ano de 2016.

Os Municípios que compõem a região de Campinas cooperam com $13 \%$ dos valores procedentes deste imposto. Tal região é composta por 30 cidades, sendo Campinas o Município de maior destaque no que concerne o angariamento proveniente do ICMS, seguido por Paulínia.

A região de Osasco, constituída por 19 prefeituras, representa a terceira região quanto aos valores recolhidos por meio do ICMS. Jundiaí, e sua região, colabora com $8 \%$ do total arrecadado, estando este dividido entre 36 cidades. As regiões de Guarulhos (com 12 Municípios), e ABCD (com 7 municipalidades), proporcionam cada uma 5\% do montante recolhido com o ICMS. As demais regiões possuem uma contribuição menos expressiva para os cofres públicos.

Deste modo, os dados expostos até o momento propuseram trazer à tona a realidade atual do Estado de São Paulo quanto o seu vínculo com o imposto que mais expressivas somas oferece para seu Tesouro. Foi possível constatar que $84 \%$ de todo o valor estadual 
arrecadado advém do ICMS. Ademais, averiguamos que tal recolhimento está dividido em três setores da economia, com considerável concentração na capital paulista.

Todavia, até o momento não foram abordadas as séries históricas relativas ao recolhimento do ICMS paulista. Desta maneira, esta será a temática analisada a partir deste ponto.

A série histórica fornecida pelo relatório da Secretaria da Fazenda do Estado de São Paulo se inicia em 1994, permitindo a compreensão do comportamento arrecadatório dos tributos paulistas a partir do momento no qual o país alcançou um importante passo nas questões referentes à estabilidade inflacionária. O Quadro 20 oferece esta análise.

\section{Quadro 20 - Histórico da Receita Tributária, (1994 a 2016)}

\begin{tabular}{|c|c|c|c|c|c|c|}
\hline & \multirow{2}{*}{\multicolumn{5}{|c|}{ RECEITA TRIBUTÁRIA }} & \multirow{3}{*}{$\begin{array}{l}\text { Valores nonimais em milhões de reais. } \\
\begin{array}{|c}\text { \% (ICMS no Total) } \\
\end{array}\end{array}$} \\
\hline \multirow{2}{*}{ Ano } & & & & & & \\
\hline & ICMS & IPVA & ITCMID & TAXAS & Total & \\
\hline 1994 & $12.829,3$ & 410,0 & 27,9 & 248,7 & $13.516,1$ & $94,92 \%$ \\
\hline 1995 & $18.163,8$ & $1.211,5$ & 53,8 & 491,9 & $19.921,2$ & $91,18 \%$ \\
\hline 1996 & $21.443,3$ & $1.501,2$ & 74,2 & 757,2 & $23.776,9$ & $90,19 \%$ \\
\hline 1997 & $22.779,4$ & $1.931,0$ & 103,3 & 873,2 & $25.687,3$ & $88,68 \%$ \\
\hline 1998 & $22.831,2$ & $2.203,3$ & 96,3 & 896,0 & $26.027,0$ & $87,72 \%$ \\
\hline 1999 & $24.823,7$ & $2.121,1$ & 113,8 & 924,0 & $27.982,9$ & $88,71 \%$ \\
\hline 2000 & $30.168,7$ & $2.414,3$ & 124,8 & $1.025,7$ & $33.733,7$ & $89,43 \%$ \\
\hline 2001 & $33.304,9$ & $2.882,2$ & 104,9 & $1.053,4$ & $37.345,4$ & $89,18 \%$ \\
\hline 2002 & $36.844,4$ & $3.266,0$ & 239,0 & $1.162,9$ & $41.512,4$ & $88,76 \%$ \\
\hline 2003 & $39.743,6$ & $3.475,3$ & 532,7 & $1.365,9$ & $45.117,4$ & $88,09 \%$ \\
\hline 2004 & $45.415,6$ & $3.951,3$ & 311,2 & $1.798,8$ & $51.477,0$ & $88,23 \%$ \\
\hline 2005 & $50.248,2$ & $4.658,0$ & 324,6 & $2.063,9$ & $57.294,7$ & $87,70 \%$ \\
\hline 2006 & $55.829,9$ & $5.563,3$ & 403,0 & $2.350,5$ & $64.146,7$ & $87,03 \%$ \\
\hline 2007 & $62.217,4$ & $6.699,4$ & 501,9 & $2.747,7$ & $72.166,3$ & $86,21 \%$ \\
\hline 2008 & $75.212,2$ & $7.712,4$ & 600,9 & $3.040,4$ & $86.565,8$ & $86,88 \%$ \\
\hline 2009 & $77.516,8$ & $8.862,2$ & 687,3 & $3.299,5$ & $90.365,8$ & $85,78 \%$ \\
\hline 2010 & $90.817,2$ & $9.403,9$ & 984,2 & $3.693,3$ & $104.898,6$ & $86,58 \%$ \\
\hline 2011 & $100.089,2$ & $10.530,5$ & $1.010,2$ & $4.158,9$ & $115.788,8$ & $86,44 \%$ \\
\hline 2012 & $107.102,0$ & $11.638,3$ & $1.276,2$ & $3.903,2$ & $123.919,7$ & $86,43 \%$ \\
\hline 2013 & $117.336,2$ & $12.415,8$ & $1.389,9$ & $4.402,5$ & $135.544,4$ & $86,57 \%$ \\
\hline 2014 & $120.482,8$ & $13.643,4$ & $1.742,1$ & $4.618,0$ & $140.486,4$ & $85,76 \%$ \\
\hline 2015 & $123.912,8$ & $14.759,2$ & $2.407,9$ & $4.947,9$ & $146.027,8$ & $84,86 \%$ \\
\hline 2016 & $123.800,6$ & $14.958,3$ & $2.353,4$ & $5.468,6$ & $146.581,0$ & $84,46 \%$ \\
\hline
\end{tabular}

Conforme já exposto em linhas anteriores, no ano de 2016 os valores oriundos do ICMS representaram aproximadamente $84 \%$ da receita estadual paulista. Entretanto, e por mais que estes percentuais sejam significativos, observamos que no decorrer de 22 anos ocorreu uma queda constante na concentração desta fonte de riquezas. 
No primeiro ano da série histórica, 1994, o recolhimento com o ICMS foi responsável por quase $95 \%$ da receita tributária. Desta maneira, é evidente a constatação de que, em termos percentuais, o ICMS sofreu um declínio de aproximadamente $11 \%$ nas arrecadações da Fazenda paulista, conforme ilustra o Gráfico 08.

\section{Gráfico 8 - Série Histórica da Arrecadacão com o ICMS, (1994 a 2016)}

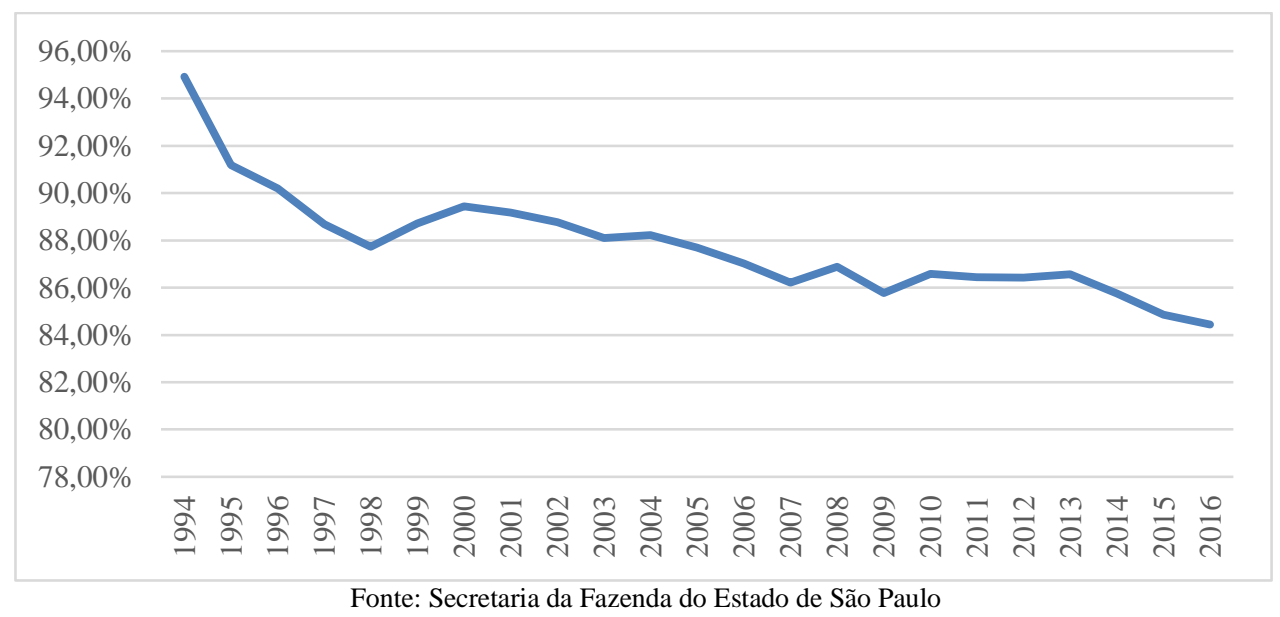

Com base nos dados apresentados, buscamos efetuar um estudo sobre a relação do Estado de São Paulo e o ICMS. Foi possível constatar que o Estado paulista contribui, atualmente, com 30\% da arrecadação nacional oriunda desta fonte de renda. Ademais, tal imposto representa para os cofres paulistas $84 \%$ de todo o recolhimento da receita tributária.

Analisamos as atividades econômicas predominantes para tal geração de recursos, bem como as regiões de São Paulo que mais benefícios trazem aos números em questão. Por último, mas não menos importante, constatamos que no decorrer de duas décadas o ICMS vem perdendo sua representatividade perante a arrecadação. Contudo, ainda apresenta valores extremamente expressivos diante do todo.

A obtenção de tais dados oferece-nos preciosas ferramentas para as reflexões sobre a realidade brasileira, e paulista, nos assuntos tributários. Como observado nos relatórios apresentados pela Receita Federal do Brasil e Secretaria da Fazenda do Estado de São Paulo, as transferências de recursos da sociedade para os cofres públicos ocorrem por meio da incidência tributária sobre o consumo, via tributação de Bens e Serviços. Averiguamos, nos números nacionais, que essa base de incidência é responsável por praticamente $50 \%$ de todo o montante tributário brasileiro. No Estado de São Paulo tal concentração torna-se ainda maior e mais expressiva, $84 \%$. 
A população, geralmente, pouco percebe o peso desta carga tributária, pois efetua o pagamento fiscal de maneira indireta, adquirindo mercadorias e/ou serviços que já possuem as alíquotas inseridas em seus preços. Temos, deste modo, a ocultação da carga tributária brasileira e, paralelamente, a falsa crença de que as camadas econômicas menos favorecidas pagam menos impostos no Brasil, uma vez que são isentas do Imposto de Renda. Ledo engano!

Adiante faremos a análise do Imposto sobre Serviços de Qualquer Natureza - ISS - no Município de São Paulo. Este imposto representa, diante do montante nacional, a sétima principal fonte de recurso tributário, conforme demonstrado no Quadro 12.

\section{O ISS na Arrecadação Municipal de São Paulo}

A busca pelo entendimento do impacto que os tributos da base Bens e Serviços ocasiona nos cofres públicos remete-nos ao estudo das três esferas de poder. Desta forma, analisaremos os números concernentes à receita tributária do Município de São Paulo, em especial a renda gerada pelo recolhimento do ISS.

Os dados a serem apresentados foram elaborados pela Prefeitura de São Paulo, Secretaria de Finanças e Desenvolvimento Econômico - Controladoria Geral, e obtidos por meio do Portal da Transparência da Prefeitura de São Paulo. Neste momento, faz-se importante mencionar que o Município paulistano oferece um diferencial quanto aos relatórios divulgados pela União e pelo Estado paulista, pois, além da receita arrecadada, também são fornecidas informações sobre os valores orçados. Tal sistemática nos permitiu averiguar se o planejamento financeiro municipal, sob a ótica da receita, se concretizou ou se ocorreram discrepâncias.

Contudo, antes de apresentarmos os dados e estudos da receita paulistana, relativos a 2016 e anos anteriores, resgataremos os dados nacionais acerca da arrecadação com o ISS na esfera nacional e o confrontaremos com os dados do Município de São Paulo.

De acordo com os números divulgados pela Receita Federal do Brasil, no ano de 2016 o somatório que o recolhimento com o ISS gerou, na esfera nacional, foi de $\mathrm{R} \$ 54.622,10$ milhões. Neste mesmo ano, a capital paulista arrecadou $\mathrm{R} \$ 11.921,76$ milhões, conforme 
ilustrado no Quadro 21. De acordo com dados divulgados pelo IBGE, o Brasil possui atualmente 5.570 cidades, no entanto, apenas um Município foi responsável por praticamente $22 \%$ da renda proveniente do ISS nacional ${ }^{8}$. Em 2015 tais proporções se mantiveram.

\section{Quadro 21 - Receita Tributária do Município de São Paulo, (2016)}

\begin{tabular}{|c|c|c|}
\hline CLASSIFICAÇÃO DA RECEITA & PREVISTO & REALIZADO \\
\hline 1 - RECEITAS CORRENTES & $\mathrm{R} \$ 23.446 .000 .314,00$ & $R \$ 23.501 .827 .556,56$ \\
\hline 1.1 - RECEITA TRIBUTÁRIA & $\mathrm{R} \$ 23.446 .000 .314,00$ & $\mathrm{R} \$ 23.501 .827 .556,56$ \\
\hline 1.1.1 - IMPOSTOS & $R \$ 23.175 .250 .584,00$ & $R \$ 23.203 .173 .587,68$ \\
\hline 1.1.1.2 - IMPOSTOS S/O PATRIMÔNIO E A RENDA & $\mathrm{R} \$ 11.080 .038 .776,00$ & $\mathrm{R} \$ 11.281 .413 .064,29$ \\
\hline 1.1.1.2.02 - IMPOSTO S/ A PROPRIEDADE PREDIAL E TERRITORIAL URBANA & $\mathrm{R} \$ 7.382 .011 .212,00$ & $\mathrm{R} \$ 7.581 .863 .776,33$ \\
\hline 1.1.1.2.04 - IMPOSTO S/ A RENDA E PROVENTOS DE QUALQUER NATUREZA & $\mathrm{R} \$ 1.762 .371 .501,00$ & $\mathrm{R} \$ 1.945 .276 .299,13$ \\
\hline 1.1.1.2.08 - IMPOSTO S/ TRANS. INTER-VIVOS DE BENS IMÓVEIS E DIR. REAIS S/ IMÓVEIS & $\mathrm{R} \$ 1.935 .656 .063,00$ & $\mathrm{R} \$ 1.754 .272 .988,83$ \\
\hline 1.1.1.3 - IMPOSTO S/ A PRODUÇÃO E A CIRCULAÇÃO & $\mathrm{R} \$ 12.095 .211 .808,00$ & $\mathrm{R} \$ 11.921 .760 .523,39$ \\
\hline 1.1.1.3.05 - IMPOSTO S/ SERVIÇOS DE QUALQUER NATUREZA & $\mathrm{R} \$ 12.095 .211 .808,00$ & $R \$ 11.921 .760 .523,39$ \\
\hline 1.1.1.3.05.01 - IMPOSTO SOBRE SERVIÇOS DE QUALQUER NATUREZA & $\mathrm{R} \$ 12.095 .211 .808,00$ & $\mathrm{R} \$ 11.921 .760 .523,39$ \\
\hline 1.1.2 - TAXAS & $\mathrm{R} \$ 270.749 .730,00$ & $\mathrm{R} \$ 298.653 .968,88$ \\
\hline TOTAIS & $\mathrm{R} \$ 23.446 .000 .314,00$ & $\mathrm{R} \$ 23.501 .827 .556,56$ \\
\hline
\end{tabular}

Fonte: Secretaria de Finanças e Desenvolvimento Econômico da Prefeitura de São Paulo - Portal da Transparência, 2018.

De acordo com o apresentado no Quadro 21, é possível observar que, em linhas gerais, o valor previsto se concretiza, sendo o realizado levemente superior ao orçado. Também é possível constatar que mais de $98 \%$ da receita tributária é proveniente de impostos, sendo o valor arrecadado com as taxas e contribuições praticamente inexpressivo diante do todo.

A Prefeitura de São Paulo possui quatro fontes de renda denominadas impostos, sendo: Imposto sobre a Propriedade Predial e Territorial Urbana - IPTU; Imposto sobre a Renda e Proventos de Qualquer Natureza; Imposto sobre Transmissão de Bens Imóveis Inter Vivos - ITBI, e; Imposto sobre Serviços de Qualquer Natureza - ISS. A receita proveniente de impostos, em 2016, foi de $\mathrm{R} \$ 23.203,17$ milhões, composta por:

A) Imposto sobre Serviço de Qualquer Natureza: R\$11.921,76 milhões - 51\% do todo;

B) Imposto sobre a Propriedade Predial e Territorial Urbana: $\mathrm{R} \$ 7.581,86$ milhões - $33 \%$ do todo;

\footnotetext{
${ }^{8}$ Valor estimado, uma vez que há divergências entre as metodologias adotadas pela a RFB e a Prefeitura de São Paulo.
} 
C) Imposto sobre a Renda e Proventos de Qualquer Natureza: R\$ 1.945,27 milhões $-8,5 \%$ do todo;

D) Imposto sobre a Transmissão de Bens Imóveis Inter Vivos: R \$ 1.754,27 milhões $-7,5 \%$ do todo.

É possível verificar que $51 \%$ da renda gerada com impostos foi oriunda do ISS, sendo essa a principal fonte de arrecadação tributária da cidade de São Paulo. Mesmo que a concentração não seja tão acentuada, como no caso do Estado com o ICMS, tal fato não pode ser ignorado. Tanto no caso do Estado quanto do Município, a tributação incidente sobre Bens e Serviços é a principal fonte de transferência de recursos da sociedade para os cofres públicos. A União possui esta ferramenta como a segunda mais importante, com $32 \%$ do montante tributário arrecadado em 2016, conforme dados apresentados em linhas anteriores.

Ademais, assim como no caso estadual, e mediante a série histórica a ser apresentada, é possível afirmar que a cidade de São Paulo não foge à regra. Ou seja, em todos os períodos analisados, a principal fonte de riqueza fiscal foi adquirida por meio da tributação incidente sobre a prestação de serviços.

Mesmo ocorrendo a diminuição na concentração de arrecadação via $I S S$, mesmo padrão observado com o ICMS no caso do Estado, o Imposto sobre Serviços sempre apresentou, na série estudada, mais de 50\% da renda dos tributos paulistanos. Em realidade, 2016 se caracteriza como o ano no qual a Prefeitura obteve menores rendimentos com tal imposto, em termos percentuais, conforme apresentado no Gráfico 09.

\section{Gráfico 9 - Série Histórica da Arrecadacão com o ISS, (2009 a 2016)}

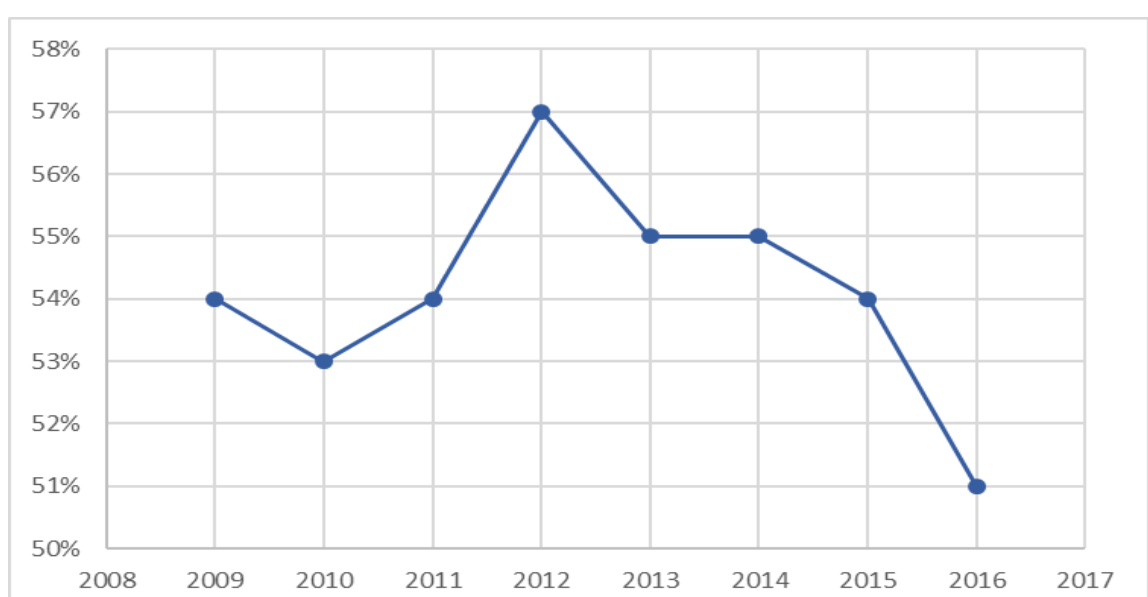


Infelizmente não há, no Portal da Transparência da Prefeitura de São Paulo, uma série longa para a análise. No entanto, de posse das informações apresentadas, é possível observar que no ano de 2012 o ISS representou quase $60 \%$ do montante tributário arrecadado. Além disso, 2016 representa uma exceção tanto em termos percentuais quanto em termos monetários, pois foi o único período no qual o ISS recolhido foi inferior ao orçado, de acordo com o exposto no Quadro 22.

Quadro 22 - Histórico Receita Tributária: Orcado versus Realizado, (2009 a 2016)

\begin{tabular}{|c|c|c|c|c|c|c|c|c|c|}
\hline & \multicolumn{4}{|c|}{ Receita Tributánira } & \multicolumn{3}{|c|}{ Receita Impostos } & \multicolumn{2}{|c|}{ Receita ISS } \\
\hline & & Ongada & & Realirada & & Oreada & Realivada & Oreada & Realivada \\
\hline 2009 & $\mathrm{RS}$ & $10.788 .805 .393,00$ & $R S$ & $11,013,394,674,15$ & $\mathrm{RS}$ & $10.580 .443 .593,00$ & $\operatorname{RS} 10.696 .783 .607,09$ & RS 5.945.443.593,00 & $\mathrm{R} \$ \quad$ 5.960.202.483,96 \\
\hline 2010 & RS & $11.782 .786 .086,00$ & $R S$ & $13.018 .003 .577,18$ & $R S$ & $11.607 .236 .248,00$ & $\mathrm{R} \$ 12,692,912,443,06$ & RS 6.188.626.233,00 & RS $6.956 .466 .881,43$ \\
\hline 2011 & RS & $14.710 .3555 .032,00$ & $R \$$ & $15.020 .109 .101,95$ & $R S$ & $14.458,959,307,00$ & $\mathrm{R} \$ 14.811 .404 .078,06$ & RS 7.863.728.453,00 & RS 8.147.925.,920,92 \\
\hline 2012 & RS & $16.657 .028 .801,00$ & $R S$ & $17.536 .088 .270,24$ & $R \$$ & $16.429,319,544,00$ & $R \$ 17.318 .382 .546,62$ & R\$ 9.112.565.183,00 & RS 9.935.281.325,57 \\
\hline 2013 & $\mathrm{RS}$ & $17.802 .795 .320,00$ & $R \$$ & $18.564 .443 .052,18$ & $\mathrm{RS}$ & $17.550 .267,955,00$ & $\operatorname{RS} 18.284 .878 .363,22$ & RS 9.704.563.939,00 & $\mathrm{R} \$ 10.136 .074 .125,55$ \\
\hline 2014 & $R S$ & $20.494 .292 .686,, 00$ & $R S$ & $20.555 .639 .639,07$ & $R S$ & $20.238 .081 .854,00$ & $R \$ 20.256 .684 .044,55$ & R\$ 10.774.689.288,00 & R\$ 11.379.496.977,91 \\
\hline 2015 & $R S$ & 22,638.721.490,00 & $R S$ & 22.448.807.178,07 & $\mathrm{RS}$ & $22.322 .270 .885,00$ & $R \$ 22.140 .231 .512,86$ & R\$ 11.863.217.228,00 & R\$ 12.129.649.024,44 \\
\hline 2016 & RS & $23.446 .000 .314,00$ & $R S$ & $23.501 .827 .556,56$ & $R S$ & $23.175 .250 .584,00$ & $\mathrm{R} \$ 23.203 .173 .587,08$ & R\$ 12.095.211.808,00 & R\$ 11.921.760.523,39 \\
\hline
\end{tabular}

Via de regra, a receita tributária, receita impostos e ISS realizadas apresentaram cifras superiores aos valores orçados. E, em anos que tal feito não se concretizou, a diferença da arrecadação foi ínfima quando comparada com o valor previsto. Ademais, os dados em questão permitem a análise acerca do aumento de receitas observado no período. Ao efetuarmos o contraste entre o ano inicial e o ano final, notamos que as três receitas sofreram um aumento consistente. A receita tributária orçada obteve elevação de mais de $117 \%$ no intervalo de 8 anos. O mesmo comportamento se dá com a receita orçada de impostos, cuja ascensão foi de $119 \%$. O acréscimo da receita prevista com o ISS foi de 103\%. Majorações similares também são sentidas nas receitas arrecadadas.

Em suma, em um curto espaço de tempo, o montante de recursos transferidos da população para a Fazenda municipal dobrou, tanto no contexto do planejamento quanto na realização. Por meio do Gráfico 10 é possível observar os comportamentos dos valores planejados e realizados no decorrer do tempo. 


\section{Gráfico 10 - Histórico Receita Tributária: Orcado versus Realizado, (2009 a 2016)}

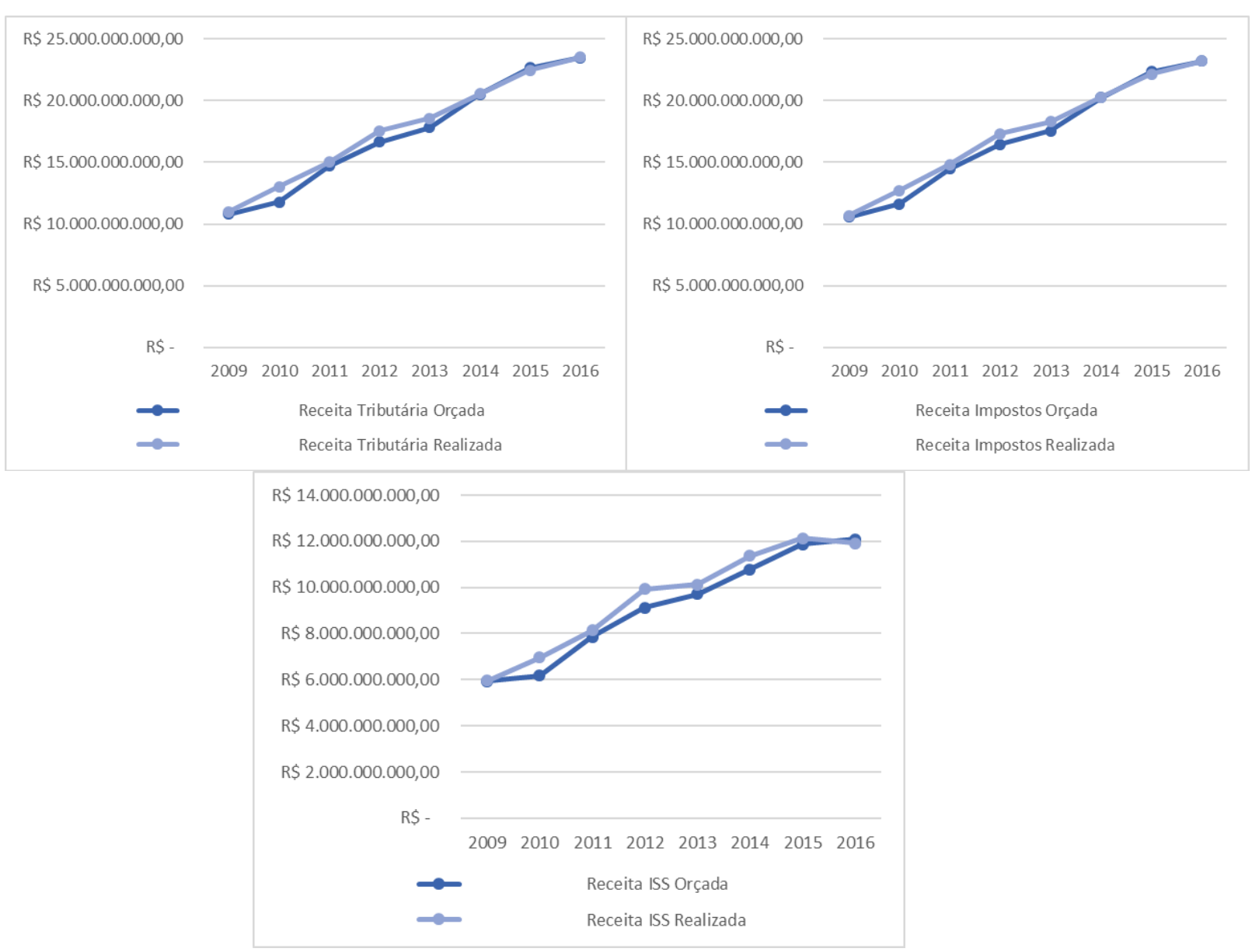

Fonte: Secretaria de Finanças e Desenvolvimento Econômico da Prefeitura de São Paulo - Portal da Transparência, 2018.

Conforme observado, as receitas orçadas e realizadas obedecem a mesma trajetória ascendente, tal qual a proporção de seus acréscimos no decorrer da série apresentada.

Por conseguinte, os dados apresentados permitiram a elucidação no tocante à composição e desenvolvimento da tributação paulistana. Constatamos o quanto o cofre municipal é dependente do setor terciário da economia e, novamente, o quão a receita pública está atrelada ao tributo encoberto no preço final da mercadoria e/ou serviço consumido. Por meio do Gráfico 11 é possível efetuar tal constatação. 


\section{Gráfico 11 - Histórico Receita Realizada, (2009 a 2016)}

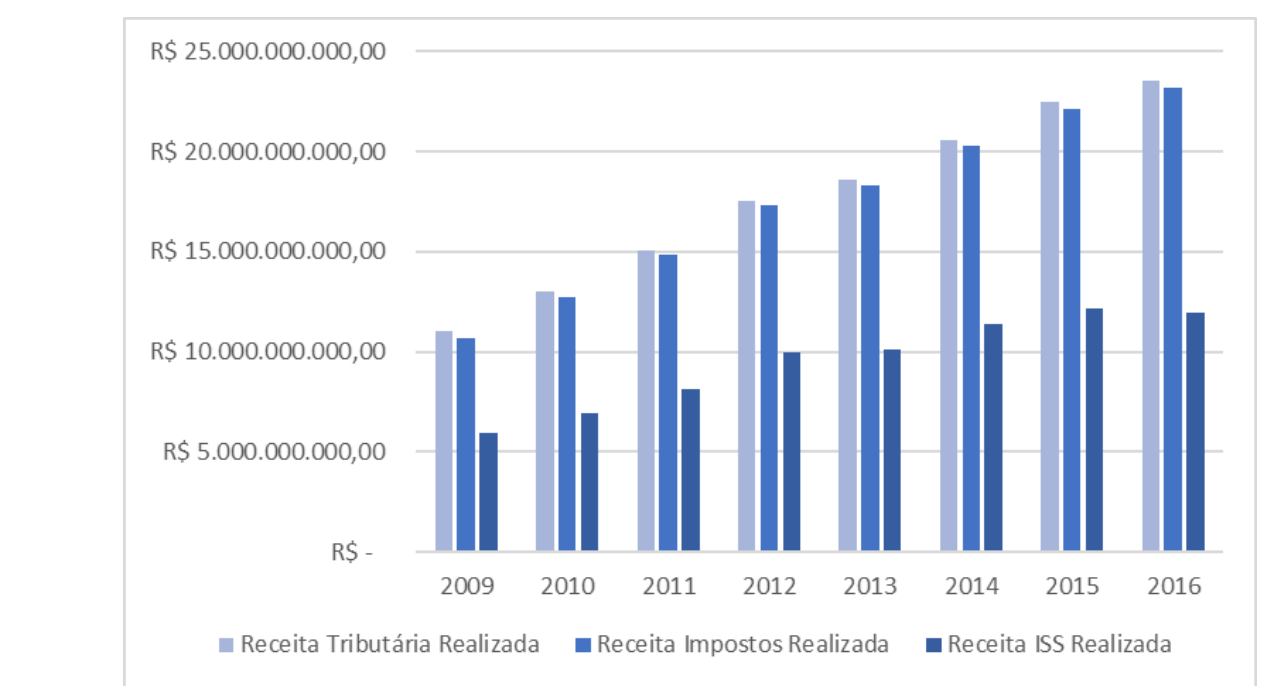

Fonte: Secretaria de Finanças e Desenvolvimento Econômico da Prefeitura de São Paulo - Portal da Transparência, 2018

Os dados e discussões apresentadas incitaram a reflexão acerca da composição tributária nacional, estadual e municipal. Sob o enfoque econômico, procuramos demonstrar a relevância que a tributação sobre Bens e Serviços possui para os cofres dos entes federativos brasileiros.

Os relatórios desenvolvidos pelas Secretarias da Fazenda das três esferas de poder proporcionaram imensurável contribuição para os estudos que ora nos ocupa. Os números analisados no decorrer do capítulo ilustraram, comprovaram e quantificaram a alta concentração e dependência dos recursos ficais brasileiros diante da atividade econômica promovida pela produção, circulação e consumo de mercadorias e serviços.

Além disso, a estratégia brasileira em concentrar seu recolhimento fiscal por meio da inserção das alíquotas no preço final do produto, seja um bem material ou um serviço, permite a ocultação tributária. Esta sistemática dificulta ao contribuinte a tomada de consciência acerca da proporção dos seus recursos que é transferida para o Governo. Temse, como resultante, uma população que, erroneamente, crê não contribuir com a carga tributária de maneira tão expressiva.

Infelizmente, grosso modo, os brasileiros percebem a "mordida do Leão" quando observam a alíquota descontada em seus holerites ou no momento da declaração anual do imposto de renda. Outros tantos, mesmo sendo a minoria, a identifica quando efetuam o resgate de suas aplicações financeiras, devendo compartilhar parte do lucro com a Nação. Desta maneira, criou-se a falsa percepção que a tributação brasileira é diretamente 
proporcional à renda, ganhos e lucros do contribuinte e, sendo assim, progressiva. Em suma, a população possui pouca, ou quase inexistente, consciência acerca dos instrumentais fiscais mais comumente utilizados no território brasileiro.

Inúmeros foram os debates, no decorrer da história brasileira, a fim de se promover uma ampla reforma tributária com o intuito de tornar o sistema fiscal mais claro e eficiente. Atualmente encontram-se em pauta no Congresso Nacional duas discussões sobre como esta reforma deveria ser conduzida e concretizada, são a Proposta de Emenda Constitucional - PEC - número 45/2019 e a PEC número 110/2019. Passemos a elas.

\section{O Imposto Único sobre Bens e Serviços}

Os dados apresentados até o momento evidenciaram o quanto a tributação nacional onera pesadamente o consumo, sendo este o principal instrumento gerador de recursos ficais para as três esferas de governo. Ademais, foi possível observar a complexidade tributária existente no Brasil. De acordo com os Quadros 12, 13 e 14, elaborados com base nos relatórios divulgados pela Secretaria da Receita Federal do Brasil, há atualmente 37 fontes tributárias em solos brasileiros. No entanto, estas informações não consideram as taxas e contribuições próprias de cada Estado e/ou Município.

Deste modo, economistas, empresários, juristas, legisladores e demais agentes da sociedade concordam quanto a necessidade em se promover uma reforma tributária a fim de simplificar a estrutura vigente. Paralelamente, tornar a tributação brasileira mais justa e equânime também está entre as preocupações, ou ao menos deveria estar. Os estudiosos da temática muito discutem acerca da regressividade tributária presente no sistema fiscal brasileiro, sendo assim, efetuar uma reforma tributária que respeite a capacidade contributiva do cidadão e passe a promover um recolhimento fiscal proporcional aos ganhos, renda e posses do contribuinte careceria maiores empenhos.

Diante do cenário que se denota, encontram-se em discussão no Legislativo duas propostas de reforma tributária. Em essência, as duas proposições concentram-se na reflexão acerca da reforma tributária sobre o consumo. O que se sugere é a implantação de um imposto único sobre o consumo, o denominado Imposto sobre Valor 
Agregado/Adicionado - IVA. Dentre as características do IVA estão a não cumulatividade do imposto (a não incidência de imposto sobre imposto), a tributação na localidade consumidora (princípio do destino) e a não adoção de benefícios e regimes tributários especiais entre os entes federativos. Segundo seus defensores, este modelo possibilita a simplificação da estrutura tributária vigente, assim como contribui para o fim da guerra fiscal existente entre os diversos entes da federação.

Ambas as propostas em trâmite argumentam em favor da unificação dos tributos incidentes sobre a base Bens e Serviços. Contudo, enquanto a PEC n ${ }^{\circ} 45 / 19$ - proposta da Câmara dos Deputados - advoga em prol do agrupamento dos cinco tributos que compõem a base Bens e Serviços (IPI, COFINS, PIS - federais-; ICMS - estadual- e ISS municipal); a PEC n 110/19 - projeto do Senado Federal - estabelece a junção de nove tributos, os cinco que compõem a base Bens e Serviços acrescentados de mais quatro (IOF, PASEP, Salário Educação e Cide Combustíveis - federais) $)^{9}$. Tanto na PEC n ${ }^{\circ} 45 / 19$, quanto na PEC $\mathrm{n}^{\circ} 110 / 19$, o imposto proveniente desta reforma, o IVA brasileiro, será denominado Imposto sobre Bens e Serviços - IBS. Contudo, além do IBS, as duas propostas possuem como objetivo criar mais um tributo, o que viria a descaracterizar o modelo do imposto único sobre o consumo:

As duas propostas criam outro imposto além do IBS, de competência da União, desta feita sem as características do IVA. Embora sejam aqui denominados de imposto seletivo, apenas o relativo à PEC 45 é seletivo propriamente dito, com a intenção de desestimular o consumo de certos bens e serviços, a exemplo de cigarros e bebidas.

Na PEC 110, o imposto seletivo é bem mais abrangente, incluindo insumos importantes utilizados no processo produtivo como combustíveis, serviços de telecomunicações e energia elétrica, além de veículos automotores. As alíquotas podem sem diferenciadas, mas sem superar a alíquota padrão do IBS, exceto nos casos de bebidas e cigarros. Dada a abrangência, o imposto visa também arrecadar e parte de sua receita é dividida com os estados. (NOTA TÉCNICA Nº 38, 2019, p. 03)

Diante das pretensões de, além do IBS, criar mais um mecanismo de recolhimento fiscal incidente sobre o consumo, nos questionamos acerca do propósito último implícito nestas propostas de reforma tributária em tramitação no Congresso. Ao propor a criação de um imposto seletivo sobre cigarros e bebidas, as propostas não estariam semeando futuras

\footnotetext{
${ }^{9}$ As duas propostas de reforma tributária consideram o PIS isolado do PASEP. No entanto, por meio do Quadro 12 podemos observar que estes tributos são calculados em conjunto. Ademais, eles foram unificados por intermédio da Lei Complementar no 26, de 11 de setembro de 1975.
} 
oportunidades de ampliação destas bases e, consequentemente, aumentando a carga tributária incidente sobre o consumo ${ }^{10}$ ?

Além disso, a PEC 110, ao objetivar a tributação em paralelo de importantes bens necessários para a cadeia produtiva não estaria gerando distorções no mercado e encarecendo o custo de vida do consumidor/contribuinte final?

Feitas estas considerações, prossigamos com a reflexão. Com o intuito de sumarizar os principais pontos de convergência e divergência entre as duas propostas, elaboramos o Quadro 23, ilustrado abaixo.

\section{Quadro 23 - Propostas de Reforma Tributária em Pauta}

\begin{tabular}{|c|c|c|}
\hline & PEC 45/19 & PEC 110/19 \\
\hline Autoria & Câmara dos Deputados & Senado Federal \\
\hline $\begin{array}{l}\text { Tributos a serem } \\
\text { substituídos }\end{array}$ & $\begin{array}{l}\text { IPI, PIS, COFINS - federal; } \\
\text { ICMS - estadual; ISS - } \\
\text { municipal }\end{array}$ & $\begin{array}{l}\text { IPI, IOF, Salário Educação, } \\
\text { PIS, PASEP, COFINS, Cide } \\
\text { Combustíveis - federal; ICMS } \\
\text { - estadual; ISS - municipal }\end{array}$ \\
\hline Imposto a ser criado & $\begin{array}{lll}\text { Imposto sobre Bens e } \\
\text { Serviços - IBS }\end{array}$ & $\begin{array}{llll}\text { Imposto sobre } & \text { Bens } & \text { e } \\
\text { Serviços - IBS } & & \\
\end{array}$ \\
\hline Alíquota & $\begin{array}{l}\text { Todos os bens e serviços } \\
\text { terão alíquota única. União, } \\
\text { Estados e Municípios terão } \\
\text { autonomia para a definição } \\
\text { de suas alíquotas }\end{array}$ & $\begin{array}{l}\text { Alíquota única para todo o } \\
\text { Brasil, estabelecida por Lei } \\
\text { Complementar no Congresso } \\
\text { Nacional. Possibilidade de } \\
\text { alíquotas diferentes para } \\
\text { alguns produtos e serviços }\end{array}$ \\
\hline Incentivos Fiscais & $\begin{array}{l}\text { Vedada a concessão de } \\
\text { incentivos e benefícios } \\
\text { fiscais. Devolução do } \\
\text { imposto pago por famílias } \\
\text { de baixa renda. Tratamento } \\
\text { diferenciado para micro e } \\
\text { pequenas empresas }\end{array}$ & $\begin{array}{l}\text { Algumas exceções para a } \\
\text { concessão de incentivos e } \\
\text { benefícios fiscais. Tratamento } \\
\text { diferenciado para micro e } \\
\text { pequenas empresas e para a } \\
\text { Zona Franca de Manaus. }\end{array}$ \\
\hline Período de Transição & $\begin{array}{l}10 \text { anos para a unificação } \\
\text { dos tributos e } 50 \text { anos para a } \\
\text { repartição das receitas do } \\
\text { IBS entre União, Estados, } \\
\text { Distrito Federal e } \\
\text { Municípios }\end{array}$ & $\begin{array}{l}5 \text { anos para a unificação dos } \\
\text { tributos e } 15 \text { anos para a } \\
\text { repartição das receitas do IBS } \\
\text { entre Estados, Distrito Federal } \\
\text { e Municípios }\end{array}$ \\
\hline
\end{tabular}

Deste modo, não está em pauta nos projetos em vigor a discussão sobre a alteração da natureza tributária brasileira, qual seja, diminuir a tributação sobre o consumo e sua consequente regressividade. O que observamos é uma preocupação em direção à

\footnotetext{
${ }^{10}$ Não desejamos nos antecipar, no entanto, o precursor do atual IPI inicialmente incidiu somente sobre o fumo. No decorrer de alguns anos sua base de incidência foi substancialmente ampliada. Este assunto será tratado com mais detalhes no último capítulo desta pesquisa.
} 
diminuição da complexidade tributária, uma vez que a União, os 26 Estados, o Distrito Federal e os mais de 5.500 Municípios possuem, cada um, seus impostos, contribuições e taxas específicas. Dirimir a burocracia, o contencioso tributário e os custos de conformidade $^{11}$ estão entre os objetivos a serem alcançados.

Paralelamente, as reformas em discussão procuram sanar a questão da intensa guerra fiscal existente no território nacional. Por meio da concessão de benefícios, isenções fiscais e regimes especiais de tributação, Estados e Municípios procuram atrair para seus territórios empresas e indústrias que possam contribuir para o desenvolvimento econômico local e regional. Esta é uma prática largamente utilizada, contudo, são as regiões menos favorecidas economicamente aquelas que mais recorrem a esta sistemática.

Deste modo, por meio da autonomia fiscal e orçamentária garantida aos entes subnacionais mediante o Pacto Federativo, observamos no Brasil uma intensa disputa interna na atração, estímulo e permanência de agentes econômicos particulares que possam auxiliar na geração de emprego e desenvolvimento regional das localidades menos favorecidas.

Em contrapartida, a guerra fiscal existente deixa suas sequelas negativas quando analisada do ponto de vista macroeconômico. Sob a ótica das finanças públicas, os governantes renunciam a um recurso fiscal em prol da atração de empresas e indústrias para seus territórios. Sob a ótica dos agentes particulares, estar distante do mercado consumidor implica em maiores custos logísticos, custos esses que serão embutidos no preço final da mercadoria a ser adquirida pelo consumidor. Destarte, também precisamos considerar no conflito o poder de barganha dos Estados e Municípios. Aqueles que possuem condições de oferecer maiores benefícios se favorecem na disputa.

Intentando eliminar a guerra fiscal, a PEC $\mathrm{n}^{\circ} 45$ propõe o fim dos benefícios fiscais. No caso da PEC $\mathrm{n}^{\mathrm{o}} 110$, o projeto prevê o estudo de casos específicos. Ademais, ao estabelecer que é a localidade consumidora que possui o direito na obtenção da parcela do $I B S$, não haverá mais motivos, do ponto de vista das empresas, em permanecer distante de seu mercado consumidor.

11 Custo dos recursos necessários ao cumprimento das determinações legais tributárias pelos contribuintes. 
Neste sentido, fica o questionamento acerca dos impactos que tais medidas poderão gerar para as localidades mais longínquas e menos desenvolvidas do país. Estariam os legisladores refletindo sobre um possível deslocamento das indústrias e empresas para regiões mais próximas de seu mercado consumidor? Neste cenário, quais medidas seriam adotadas a fim de amenizar o possível aumento da taxa de desemprego e queda na atividade econômica das regiões impactadas negativamente por tal deslocamento destes agentes econômicos?

Lembremo-nos que a tributação brasileira incide, em predominância, sobre o consumo. Sem emprego e sem atividade econômica o consumo e a arrecadação estarão comprometidos. Em última instância, o governo também será prejudicado. Neste "jogo" todos os "players", públicos e privados, perdem. Não há vencedores!

Além disso, com a unificação dos tributos sobre o consumo, como se daria a definição da alíquota a ser aplicada? Há algumas diferenças entre as duas propostas:

Na PEC 45, a alíquota do IBS é definida por meio de lei específica de cada ente, a regulamentação e a gestão é da União, Estados e Municípios, e não é permitida a concessão de benefícios tributários, nem a diferenciação de alíquotas entre bens e serviços. Já na PEC 110 a alíquota é a mesma para todos os entes, fixada em lei complementar, a gestão e a regulamentação são atribuídas apenas aos Estados e Municípios, e existe a possibilidade de diferenciação de alíquotas entre bens e serviços e a concessão de benefícios nos casos especificados. (NOTA TÉCNICA No 38,2019 , p. 04)

Deste modo, ao estabelecer uma alíquota única ou padronizada e a destinação dos recursos para a localidade consumidora, as propostas preveem a criação de um órgão central, o Comitê Gestor, que será incumbido em promover o recolhimento da receita fiscal e o posterior envio do recurso ao ente federado de direito. Sendo assim, o recolhimento tributário passará a ser efetivado de maneira centralizada.

No caso da PEC $n^{\circ} 45$ este órgão será representado pelos três entes federados. A PEC $n^{\circ}$ 110 estabelece que somente os Estados e Municípios serão representados. Neste sentido, ambas as propostas estabelecem um período de adaptação, tanto para a unificação dos tributos e consolidação do IBS, quanto para a estruturação e reorganização das finanças e das esferas administrativas governamentais. De acordo com a PEC $\mathrm{n}^{\circ} 45$, a consolidação dos cinco tributos se dará no período de 10 anos; a repartição dos recursos do IBS entre União, Estados, Distrito Federal e Municípios será concluída ao final de 50 anos. A PEC 
$\mathrm{n}^{\mathrm{o}} 110$ estabelece a unificação dos nove tributos no período de 5 anos e a repartição dos recursos entre Estados, Distrito Federal e Municípios no prazo de 15 anos.

Uma nova provocação se faz pertinente neste momento. Seria este modelo centralizado de recolhimento e posterior distribuição de receitas fiscais o mais apropriado para o Brasil? Haveria em nossa historiografia situação análoga que nos permitisse tal reflexão? Os próximos capítulos se ocuparão desta temática.

Como podemos observar, a questão fiscal não deve ser considerada como uma variável isolada dos demais contextos econômicos, regionais e históricos. Procurar respostas que, aparentemente, são mais ágeis não implica em encontrar as soluções mais eficientes. Seria este um comportamento cíclico e vicioso apresentado por nossos governantes no decorrer dos séculos? Seria essa a construção histórica herdada: a agilidade tributária em prol da eficiência? Em caso afirmativo, seria possível observar os desdobramentos de tais escolhas e posturas adotadas no início de nossa colonização ainda no século XXI? E, novamente em caso afirmativo, quais seriam os instrumentais arrecadatórios utilizados no passado que perduram até os dias atuais? Em essência, o questionamento primordial é: como chegamos neste "estado de coisas"? As páginas vindouras ocupar-se-ão em responder estas questões. 


\section{Capítulo 2}

\section{Notas Sobre a Tributação no Brasil Colônia}

Compreender a dinâmica tributária praticada no Brasil Colônia é a tônica deste capítulo. Sendo assim, o objetivo desta análise consiste em identificarmos quais foram as usuais estratégias e ferramentas de arrecadação praticadas no período. Traçar este fio condutor é de extrema importância para que possamos repensar a estrutura arrecadatória atual, bem como avaliarmos sobre as possíveis continuidades e/ou rupturas do modelo adotado inicialmente.

As características econômicas predominantes no período que nos ocupa foram largamente discutidas por estudiosos consagrados de nossa historiografia. Desta maneira, suas obras serão utilizadas como ponto de apoio para a reflexão sobre como se deu a prática arrecadatória e as oportunidades enxergadas pelo fisco. Além disso, inúmeros são os pesquisadores que procuram refletir o nosso passado tributário, oferecendo-nos contribuições ímpares para o debate e entendimento da questão.

Isto posto, com o intuito de reconstruirmos a narrativa econômica e histórica, sob a ótica da fiscalidade, procuramos estruturar este capítulo em ordem cronológica, iniciando a análise no século XVI e findando-a no século XVIII. Para tanto, serão abordadas as principais características econômicas de cada período, bem como seus principais tributos. Começaremos as discussões com a economia açucareira nos séculos XVI e XVII e os tributos a ela inerentes. Adiante, trataremos da mineração no século XVIII e das novas possibilidades econômicas e tributárias oriundas desta atividade.

Em essência, temos como meta demonstrar que o processo pelo qual se deu a colonização e exploração do território brasileiro contribuiu para a definição e configuração da carga tributária atual. A cada novo estágio do processo de ocupação novas formas de tributar foram inseridas, sem se abandonar as já existentes. À Coroa interessava intensificar as receitas oriundas de sua Colônia, não havendo critérios muito menos análise sobre a capacidade contributiva daqueles que aqui habitavam. 


\section{Dízimos e os Impostos Alfandegários, Séculos XVI e XVII}

O século XV é marcado pelas grandes navegações e descobertas de territórios ainda não civilizados, de acordo com o modelo de sociedade europeu vigente no período. Contudo, há que se frisar que as navegações tinham como objetivo primordial o comércio. "Em suma e no essencial, todos os grandes acontecimentos desta era a que se convencionou com razão chamar de "descobrimentos", articulam-se num conjunto que não é senão um capítulo da história do comércio europeu". (PRADO JR., 1995, p. 13) É neste contexto que os portugueses chegam à então nomeada "Ilha de Vera Cruz", no ano de 1500.

Em um primeiro momento julgou-se que esta terra nada tinha a oferecer a não ser a exploração do pau-brasil. Tem-se início a extração da madeira mediante concessão da Coroa portuguesa $^{12}$. Àquele cuja concessão era autorizada cabia o pagamento ao Erário luso de $20 \%$ da produção (o quinto) e a construção de fortificações ao longo da costa.

A situação de aparente abandono das terras recém conquistadas durou aproximadamente 30 anos. Contudo, as tentativas de invasão por nações inimigas levaram a Coroa portuguesa a iniciar o processo de colonização de seu território americano. Neste contexto, era preciso oferecer aos que se aventurassem a atravessar o Atlântico, e iniciar uma vida nova em território até então inóspito, oportunidade de ganhos e enriquecimento. É certo afirmar que o processo de colonização do Brasil está intimamente ligado ao cultivo e comércio do açúcar, bem como à exploração da mão de obra escrava e predominância dos grandes latifúndios ${ }^{13}$.

Todavia, antes de iniciarmos as discussões sobre o açúcar, não podemos deixar de enfatizar que o objetivo da Metrópole não consistiu em colonizar o Brasil com o anseio de povoá-lo e aqui constituir uma sociedade, ao menos não nesta etapa inicial. As intenções portuguesas foram evitar a perda do território e explorar a terra o máximo

\footnotetext{
12 “(...) a extração do pau-brasil foi desde o início considerada monopólio real. Para dedicar-se a ela tornava-se necessária uma concessão do soberano. (...) A primeira concessão relativa ao pau-brasil data de 1501 e foi outorgada a um Fernando de Noronha, (...), associado a vários mercadores judeus. A concessão era exclusiva, e durou até 1504". (PRADO JR., 1995, p. 26) "Essa concessão significava que os interessados nessa atividade deveriam pagar ao rei português uma determinada quantia em dinheiro (ou em espécie), recebendo o direito de explorar a madeira por um determinado tempo". (AMED; NEGREIROS, 2000, p. 36);

${ }^{13}$ Não constitui foco deste trabalho analisar os pormenores das questões relacionadas aos latifúndios e a utilização da mão de obra escrava. No entanto, debates consideráveis sobre a temática são apresentados por FERLINI, Vera Lúcia Amaral. Açúcar e Colonização. São Paulo: Alameda, 2010.
} 
quanto fosse possível. Paralelamente, tais objetivos exploratórios também foram a base da tomada de decisão dos migrantes que aceitaram transpor o oceano. Sobre este aspecto, Caio Prado Jr. tece importantes contribuições:

No seu conjunto, e vista no plano mundial e internacional, a colonização dos trópicos toma o aspecto de uma vasta empresa comercial, mais complexa que a antiga feitoria, mas sempre com o mesmo caráter que ela, destinada a explorar os recursos naturais de um território virgem em proveito do comércio europeu. É este o verdadeiro sentido da colonização tropical, de que o Brasil é uma das resultantes; e ele explicará os elementos fundamentais, tanto no social como no econômico, da formação e evolução histórica dos trópicos americanos. Se vamos à essência da nossa formação, veremos que na realidade nos constituímos para fornecer açúcar, tabaco, alguns outros gêneros; mais tarde ouro e diamante; depois algodão, e em seguida café, para o comércio europeu. Nada mais que isto. É com tal objetivo, objetivo exterior, voltado para fora do país e sem atenção a considerações que não fossem o interesse daquele comércio, que se organizarão a sociedade e a economia brasileiras. (PRADO JR., 1995, pp. 22-23)

Em suma, buscava-se fazer das terras brasileiras fornecedoras de produtos para abastecer o mercado consumidor europeu, inexistindo a preocupação em constituir um mercado interno e o fortalecimento do Brasil enquanto Nação.

\section{O açúcar: Monocultura voltada para a exportação, latifúndio e mão de obra escrava}

Como apontado acima, procurando evitar a perda de sua propriedade americana, a Coroa portuguesa decide iniciar o processo de colonização das terras brasileiras em meados de 1530. Foram criadas as Capitanias Hereditárias, aonde os responsáveis pelos territórios eram obrigados a zelar pela segurança e impedir ataques ultramar, para isso construindo fortificações por toda a costa ${ }^{14}$. Em contrapartida, com o intuito de estimular a produção de açúcar, "favores especiais foram concedidos subsequentemente àqueles que instalassem engenhos: isenções de tributos, garantia contra a penhora dos instrumentos de produção, honrarias e títulos, etc.” (FURTADO, 2007, p. 75) Tem-se o início do cultivo da cana-de-açúcar em solos brasileiros.

Entretanto, a opção pelo plantio da cana e comercialização do açúcar não se deu por acaso, as técnicas de cultivo já eram conhecidas pelos portugueses há longo tempo. Ademais, tal

\footnotetext{
${ }^{14}$ A exigência da defesa do território se deu desde o início da exploração do pau-brasil, sendo essa uma prática corriqueira da Coroa.
} 
mercadoria era considerada item de luxo pelos europeus, visto que "até nos enxovais de rainhas ele chegou a figurar como dote precioso e altamente prezado". (PRADO JR., 1995, p. 20) Desta maneira, colonizar o território americano por meio das grandes plantações de cana-de-açúcar representou para o Reino uma estratégia assertiva e bemsucedida, oferecendo à Coroa a solução dos problemas sobre as invasões das terras, bem como oportunidade de ganhos financeiros consideráveis através da comercialização do dito produto no mercado europeu.

O Nordeste brasileiro promoveu a consolidação e ampliação da produção açucareira por oferecer clima favorável para o plantio. Além disso, este território estava geograficamente mais próximo do continente europeu, propiciando o transporte da mercadoria. As Capitanias da Bahia e Pernambuco se destacaram nesta atividade sendo favorecidas, consequentemente, por uma situação de pungência econômica. Contudo, é equivocada a ideia sobre ter sido somente nesta região que ocorreu a inserção da cultura canavieira:

A distribuição geográfica da cana é ampla: encontramo-la disseminada por todo litoral, do extremo Norte, no Pará, até o Sul, em Santa Catarina; e no interior, salvo nas regiões semiáridas do sertão nordestino, ela aparece, em maior ou menor escala, por todas as zonas habitadas do território da colônia. (...) Os seus grandes centros produtores, todavia, aqueles que "contam" restringem-se a algumas poucas e restritas áreas do litoral. É aí que se localiza o que propriamente constitui a grande lavoura açucareira. No mais, trata-se apenas de uma pequena produção local, onde aliás a cana é muito menos aproveitada para fabricação do açúcar que para a aguardente, do melado ou da rapadura; e de pequena expressão no conjunto da economia canavieira. O litoral nordeste, da Paraíba ao Sergipe, e os contornos do Recôncavo Baiano, formam as duas áreas mais importantes e mais antigas. (PRADO JR., 2011, p. 150)

Após a etapa inicial, e superadas as dificuldades de instalação, a Colônia se destacava como grande produtora de açúcar. "Por volta de 1600, o Brasil possuía entre 190 e 200 engenhos, produzindo anualmente cerca de 600 mil arrobas, ou 8 a 9 mil toneladas de açúcar. Em 1625, a produção anual foi estimada em 960 mil arrobas, quase 14 mil toneladas". (SCHWARTZ, 1988, p. 148) No decorrer do século XVII observa-se um surpreendente crescimento de engenhos. No início do século XVIII o Padre Antonil, testemunha ocular, faz um relato referente ao número de engenhos existentes no Brasil e suas respectivas produções:

Contam-se no território da Bahia, ao presente, cento e quarenta e seis engenhos de açúcar moentes e correntes, além dos que se vão fabricando, uns no Recôncavo, à beira-mar, e outros pela terra dentro, que hoje são de maior rendimento. Os de Pernambuco, posto que menores, chegam a 
duzentos e quarenta e seis, e os do Rio de Janeiro, a cento e trinta e seis. (...) E juntas todas estas caixas de açúcar que se fazem um ano por outro no Brasil, vem a ser trinta e sete mil e vinte caixas ${ }^{15}$. (ANTONIL, 1982, p. 140)

Assim sendo, no decorrer de um século o número de engenhos mais que duplicou, saltando de 200 para aproximadamente 528, além da constituição de mais um centro produtor: o Rio de Janeiro.

Ao efetuarmos um exercício de reflexão acerca da economia canavieira podemos afirmar que estamos diante e um empreendimento lucrativo e próspero, proporcionando à Metrópole papel de destaque, praticamente monopolístico, diante do mercado internacional. Sumariamente, Prado Jr. traduz tal cenário:

Durante mais de século e meio a produção do açúcar, com as características assinaladas, representará praticamente a única base em que assenta a economia brasileira. Aliás, sua importância, mesmo internacional, é considerável. Até meados do séc. XVII o Brasil será o maior produtor mundial de açúcar, e é somente então que começarão a aparecer concorrentes sérios: as colônias da América Central e Antilhas. (PRADO JR., 1995, pp. 38-39)

Entretanto, tal proeminência econômica não resultou na criação e fortalecimento de um mercado interno em solos brasileiros. Ledo engano supor que havia algum vínculo econômico entre as capitanias açucareiras, bem como entre outras localidades do vasto território americano pertencente a Portugal. O que se observou, em realidade, são áreas que pouco se inter-relacionavam, havendo escassa atividade econômica interna. Diante desta conjuntura, as grandes fazendas produtoras de açúcar eram praticamente autossuficientes, cultivando também os itens de subsistência necessários para a sobrevivência da população livre e escrava que ali estava instalada. "A grande propriedade açucareira é um verdadeiro mundo em miniatura em que se concentra e resume a vida toda de uma pequena parcela da humanidade". (PRADO JR., 1995, p. 38)

Diante deste contexto é possível afirmar que "o fluxo de renda se estabelecia, portanto, entre a unidade produtiva, considerada em conjunto, e o exterior" (FURTADO, 2007, p. 87), inexistindo quase por completo a circulação monetária na Colônia. Acerca desta escassez de moeda metálica, e praticamente ausência de sua necessidade no cenário econômico do Brasil colonial, Vieira corrobora:

\footnotetext{
${ }^{15}$ Cada caixa continha trinta e cinco arrobas, de acordo com os dados fornecidos por Antonil.
} 
O produtor não necessitava numerário, porque o pagamento do trabalho se reduzia à manutenção do escravo: um teto na senzala, a veste grosseira de algodão, o alimento na gamela. Os próprios feitores e empregados qualificados recebiam principalmente in natura. Durante todo o período colonial, nas zonas de produção, o regime de trocas diretas constitui regra, existindo antes a mercadoria moeda do que propriamente a moeda metálica. (VIEIRA, 1973, p. 350)

Desse modo, procuramos reconstruir em breves linhas as principais características econômicas e sociais da Colônia nos séculos XVI e XVII: monocultura voltada para a exportação, latifúndio, predominância da mão de obra escrava, ausência de atividade econômica interna e escassez monetária. Dado este ensejo, quais seriam as opções disponíveis para o fisco português em sua posse americana?

\section{A dinâmica tributária}

Extração do pau-brasil e cultura canavieira foram as atividades econômicas mais lucrativas à Metrópole no período acima exposto. Contudo, além do extrativismo e da agricultura, quais outras vantagens financeiras poderiam ser exploradas? Ao Erário luso coube a oportunidade em arrecadar um percentual de toda a produção oriunda das terras brasileiras, além de tributar as mercadorias importadas e exportadas destes solos. As próximas linhas concentrar-se-ão em reconstruir tal dinâmica tributária. Todavia, antes de abordarmos este ponto, fazem-se necessários alguns esclarecimentos sobre a administração fazendária introduzida no Brasil e a maneira como o recolhimento tributário era efetuado.

As questões fiscais são, e sempre foram para o Estado, um ponto sensível e de imensurável relevância, representando sua principal fonte de receitas. Sendo assim, é de se supor a implantação de mecanismos rígidos de arrecadação e forte fiscalização a fim de se evitar a evasão. Logo, poderíamos inferir acerca de uma intensa presença da Coroa, coordenando e implantando uma estrutura fiscal estrategicamente refletida e instalada no Brasil Colônia, correto? Não exatamente! Na realidade, o que se observou foi um controle fiscal muito distante daquilo que seria considerado ideal e satisfatório. Procurando analisar o processo da colonização como um todo, Holanda esclarece:

Essa exploração dos trópicos não se processou, em verdade, por um empreendimento metódico e racional, não emanou de uma vontade construtora e enérgica: fez-se antes com desleixo e certo abandono. Dir-se- 
ia mesmo que se fez apesar de seus autores. (HOLANDA, 2014, pp. 4950)

Diante dos apontamentos é possível afirmar que as decisões adotadas foram uma resposta aos desafios apresentados. A Coroa, ou seus representantes, decidia e agia de acordo com as situações demandadas no momento, não havendo uma ação previamente refletida. "A rotina e não a razão abstrata foi o princípio que norteou os portugueses". (HOLANDA, 2014, p. 131)

Destarte, é bem verdade que ocorreu por parte do Reino certa preocupação com a estrutura fiscal. Por meio de seus estudos sobre a administração no Brasil colonial, Graça Salgado nos oferece elucidações no tocante à Fazenda:

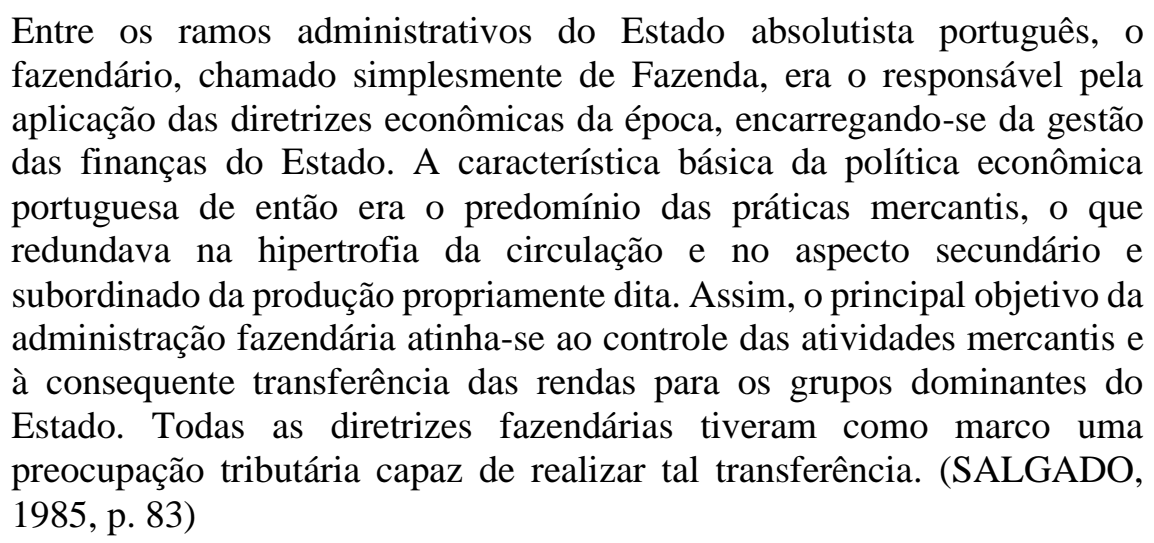

Contudo, levar em consideração somente as palavras de Salgado pode nos conduzir a um equívoco a respeito daquilo que se realizou de fato. Não estamos negando o interesse de Portugal concernente aos assuntos fiscais, muito menos afirmando que não importava aos lusos a receita oriunda das fontes tributárias. No entanto, não coube à Coroa, ao menos não neste momento, o zelo que a temática requeria. Em sua análise sobre a administração instalada na Colônia, Prado Jr. acrescenta consideráveis ponderações sobre os órgãos fazendários:

Para gerir o Real Erário nas capitanias do Brasil, arrecadar tributos e efetuar despesas, há uma série de órgãos paralelos com funções mais ou menos especializadas. Eles não se subordinam uns aos outros, nem ao governador, no sentido em que hoje entendemos a hierarquia administrativa. É neste terreno que a falta de simetria e organização hierárquica regular, que já assinalei como um dos traços característicos do governo colonial, aparece de modo mais flagrante. ${ }^{16} \mathrm{O}$ órgão principal da administração fazendária é a Junta da Fazenda, que tem forma colegial e é presidida pelo governador. Cabem à Junta de uma forma geral as atribuições que seu nome indica; mas as execuções são numerosas,

\footnotetext{
${ }^{16}$ Grifo nosso.
} 
particularmente nas capitanias de maior importância, e cabem na competência de órgãos paralelos: Junta de Arrecadação do Subsídio Voluntário, também presidida pelo governador; a Alfândega, que arrecadava os direitos de importação; o Tribunal da Provedoria da Fazenda, que é não só o que hoje são as procuradorias fiscais, mas exerce também outras funções fazendárias. Segue o Juízo da Conservatória dos vários contratos: dízimos, azeite, sal; Juízo da Coroa e Execuções; Juízo do Fisco, das Despesas etc. E todos esses órgãos, como sempre, exercem cumulativamente funções que hoje distinguiríamos em judiciárias e administrativas. (PRADO JR., 2011, p. 340)

Deste modo, fica evidente a falta de coordenação do aparato fiscal administrativo instalado na Colônia, bem como a ausência de uma hierarquia responsável por centralizar as diretrizes fiscais e promover a atuação arrecadatória de maneira sistemática e igualitária nas Capitanias. Os diversos órgãos pouco se comunicavam, cada um atuando de acordo com a necessidade que a realidade local apresentava.

Ademais, dada a dificuldade que havia no Brasil Colônia referente à arrecadação em si, o que se observou neste período foi a arrematação de contratos por meio de agentes particulares, prática esta largamente utilizada em todo o período colonial. Em síntese, a Coroa terceirizava àqueles que oferecessem o melhor lance de arrematação, tal qual um leilão, o direito de arrecadar os tributos, fazendo do Juízo da Conservatória dos vários contratos um dos principais órgãos fazendários do período. Sobre a arrematação, Prado Jr. elucida:

A arrecadação dos tributos (...) se fazia em regra por "contrato", isto é, entregava-se a particulares por um certo prazo, geralmente três anos, e por uma determinada soma global que o contratador se obrigava a pagar ao Erário, em troca dos tributos que arrecadaria por sua conta. Os "contratos" eram postos em hasta pública, e entregues a quem mais desse. Quando o Erário fazia a arrecadação por sua conta - o que acontecia raramente, pois ele não estava aparelhado para isso -, dizia-se que ele a "administrava", que o contrato estava sob "administração". (PRADO JR., 2011, p. 341)

Aos agentes particulares que arrematavam os contratos dava-se o nome de Rendeiros ou Contratadores. Uma vez firmado o contrato, cabia a estes cidadãos a incumbência em efetuar a cobrança e arrecadação dos tributos estipulados no contrato, bem como repassar ao Erário a parte que lhe era devida. Sobre a característica do cargo, sua função e atribuição, Salgado esclarece: 
Cargo: Rendeiro(s)/Contratador(es); (criação: 17.12.1548).

Nomeação: na realidade, tratava-se mais de uma arrematação, em leilão, dos contratos de arrendamento para a cobrança de rendas e direitos, em prazo definido pelo provedor-mor.

Requisitos: dar como fiança $10 \%$ do valor dos contratos de arrendamento.

Atribuição: Receber, na capitania, as rendas e direitos estipulados no seu contrato de arrendamento, prestando contas ao almoxarife nos prazos determinados. (SALGADO, 1985, p. 163)

Buscando maiores esclarecimentos sobre a atuação dos agentes da Coroa nos assuntos fiscais, Castro apresenta as instruções dadas ao Provedor-Mor da Fazenda por meio do Regimento de 17 de dezembro de 1548, Regimento este que criou o cargo de Contratador na Colônia:

No regimento de 17 de dezembro de 1548, dando instruções ao ProvedorMor da Fazenda. D. Antônio Cardoso de Barros, que foi companheiro de viagem de Tomé de Souza, se leem os seguintes deveres:

a) Informar quantos oficiais da Fazenda estão encarregados de prover e arrecadar as rendas reais; e remeter uma relação das mesmas rendas;

b) Providenciar sobre a escrituração dos direitos reais cobrados não somente na capitania da Bahia, como em todas as outras, que o provedor-mor era obrigado a visitar e fiscalizar;

c) Classificar as rendas e direitos em ramos apartados, devendo os mesmos serem arrematados em público pregão; e

d) Estabelecer casas para alfândegas nos portos de mar. (CASTRO, 1989, p. 18)

Desta maneira, fica evidente que desde o início da colonização a estrutura fiscal foi pensada tendo em vista a figura do Contratador. Contudo, tal característica administrativa não constituiu um sistema inovador e exclusivo do Brasil Colônia, "justificava-se aliás porque estava nos métodos fiscais de todas as nações contemporâneas, e tinha atrás de si uma tradição de séculos que vinha desde o Império Romano”. (PRADO JR., 2011, p. 341) Ademais, esta estrutura se caracterizava por priorizar a facilidade na arrecadação em detrimento da eficiência, importando para a Coroa o menor esforço necessário para promover o recolhimento tributário, mesmo que tal tomada de decisão acarretasse menos recursos aos cofres lusos.

De mais a mais, este sistema de arrecadação não oferecia garantias para o Erário, pois os Rendeiros, na expectativa de arrematar os contratos, muitas vezes ofereciam lances superiores ao valor que o contrato podia render, ocasionando em inadimplência e falta de repasse das verbas para a Fazenda. Como bem colocado por Graça Salgado, havia a 
exigência em dar como fiança $10 \%$ do valor do contrato, contudo, nada se podia afirmar quanto ao recebimento dos $90 \%$ restantes.

Além disso, "os ávidos contratadores, sem outra consideração que o negócio em vista, não tinham contemplação nem tolerância”. (PRADO JR., 2011, p. 341) Muitas vezes usavam de extrema violência para efetuar a arrecadação dos tributos, sendo também rotineira a prática da cobrança de uma única vez dos valores referentes ao período de todo o contrato, normalmente três anos, para se pouparem novas idas à localidade produtora. Diante desta nefasta atividade, os cobradores de tributos "iam pelo seu caminho arruinando os lavradores e paralisando a produção". (PRADO JR., 2011, p. 343)

Consequentemente, a aparente facilidade e praticidade em arrematar os contratos tributários representava para a Coroa prejuízos incalculáveis. Se, por um lado, Portugal ansiava em receber os tributos por meio de mecanismos que demandassem poucos investimentos estruturais e administrativos, por outro, receberia tão somente os valores determinados nos contratos, quando recebesse. Todo o montante superavitário ao contratado ficava nas mãos dos particulares, representando esta cifra lucros para estes senhores. Portanto, as arrematações dos contratos "constituíam em princípio um dos melhores negócios da época" (PRADO JR., 2011, p. 342) para os agentes particulares, por enxergarem nesta atividade uma oportunidade ímpar de enriquecimento.

Por consequência, os Rendeiros se beneficiavam duplamente desta transação. Além de se favorecerem com o excedente tributado, também contavam com a oportunidade de comercialização dos tributos arrecadados in natura. Como no Brasil Colônia havia intensa escassez monetária, nada mais natural que o pagamento dos tributos se desse por meio das próprias mercadorias produzidas. Deste modo, além de cobradores de tributos, estes senhores também exerciam a função de comerciantes da mercadoria arrecadada, repassando para o Fisco, em espécie, somente o valor estipulado em contrato. Acerca do pagamento tributário in natura, havia aqueles que defendessem tal tributação, conforme retratado por Vieira:

Os impostos não devem ser pagos só em espécie, porque a moeda pode tornar-se escassa para uso comercial e bancário, se o seu maior volume for desviado para o pagamento de impostos. Considerando-se que a Colônia já possuía menos moeda que a Metrópole, tanto assim que não raro havia necessidade de recorrer a mercadorias que servissem de moeda, o pagamento anual dos tributos em espécie poderia causar graves danos à economia colonial. Ademais, o Estado utilizava mercadorias para o seu próprio consumo. Mas como último e decisivo argumento, aparecia o 
verdadeiro interesse no recolhimento dos impostos in natura: o Estado vendendo os tributos recebidos podia ser beneficiado por melhoria de preços nos mercados consumidores e desta forma ganhar mais. (VIEIRA, 1973, p. 343)

Devemos apenas enaltecer que, ao contrário do afirmado por Vieira, não era o Estado quem se favorecia desta operação, como já discutimos acima, mas sim os agentes particulares. Além disso, “como estes dizimeiros ${ }^{17}$ operavam em nome do rei, estavam isentos dos impostos de exportação e dos fretes a que os colonos se tinham de sujeitar" (VIEIRA, 1973, p. 344), favorecendo-se também de certos privilégios fiscais e custos logísticos. Em suma, inúmeras vantagens financeiras colocavam estes senhores em situação de privilégio em relação aos demais.

Todavia, sob o ponto de vista do Reino, e segundo seus interesses financeiros, tal tomada de decisão não fora feita de maneira inconsciente ou ingênua. Portugal tinha ciência que lhe seria mais vantajoso receber os tributos in natura. Entretanto, optou novamente pela praticidade em detrimento da eficiência e oportunidade de melhores retornos monetários:

Era preciso tirar da colônia o dinheiro necessário às despesas da Corte e à manutenção do poderio político-militar da metrópole. Era, portanto, mais prático e imediato receber menor soma em dinheiro do que comerciar os produtos nos mercados europeus, embora com possibilidade de ganhar mais. (VIEIRA, 1973, p. 344)

Já para o contribuinte o cenário era calamitoso, uma vez que todo o pagamento feito por meio dos tributos não reverberava em melhorias estruturais e nas condições de vida da população, princípio este que rege a arrecadação tributária. As extorsões sofridas implicavam, tão somente, em lucro para os representantes particulares da Coroa, representantes esses que por meio do seu direito de arrecadar tributos não mediam esforços, muito menos as consequências de seus atos. Diante dos vexames ocorridos no momento da arrecadação não havia alternativa ao produtor, principalmente o pequeno, que não a redução do seu nível de produção:

Salvo o caso das grandes lavouras altamente remuneradoras e bastante seguras, ninguém ousava produzir mais que o estritamente necessário para o consumo próprio ou para um mercado absolutamente garantido e conhecido de antemão. (VIEIRA, 1973, p. 342)

No entanto, indo na contramão dos fatos vexatórios e abusivos, os mercantilistas da época defendiam a cobrança tributária in natura, afirmando que ela representava uma estratégia

\footnotetext{
17 Os Contratadores/Rendeiros eram comumente chamados de dizimeiros, por ser o dízimo o imposto mais importante do período e que mais interesse incitava na arrematação dos contratos.
} 
assertiva. Além disso, criam que tal sistemática arrecadatória favorecia o aumento da produção e não sua queda. Novamente Vieira colabora com a questão:

O recolhimento dos dízimos e dos quintos ${ }^{18}$ era considerado, pelos mercantilistas, a mais inteligente e fecunda das formas de arrecadação, não apenas pelos seus efeitos financeiros, mas principalmente pelos seus resultados econômicos. Enquanto os impostos recebidos em moeda empobreciam os súditos - diziam - porque representavam parcelas retiradas à fortuna privada e diminuem o capital disponível para aplicações em outras atividades, os dízimos e os quintos estimulam a produção, porque para pagá-los é preciso produzir. O aumento da sua arrecadação é o melhor índice de prosperidade nacional, porque indica que a produção colonial está em crescimento, sendo, portanto, sinal de prosperidade, razão pela qual nenhum colono inteligente e compreensivo deveria revoltar-se com o pagamento de tributos ${ }^{19}$. (VIEIRA, 1973, p. 343)

É provável que os mercantilistas não possuíssem consciência acerca da prática arrecadatória largamente utilizada pelos Contratadores, bem como os atos de violência provenientes desta atividade. Não seria plausível defender a elevação da produção se houvesse conhecimento sobre os desmandos cometidos.

Deste modo, diante dos estudos apresentados podemos concluir que estava instaurada no Brasil uma prática arrecadatória que oferecia prejuízos, tanto no contexto microeconômico quanto macro. De acordo com o exposto, a população colonial sofria incalculáveis atos de violência e, paralelamente, não encontrava outra saída a não ser diminuir a sua produção a fim de evitar um pagamento tributário superior ao legalmente exigido, impactando a atividade econômica e as oportunidades de trocas com o exterior.

As finanças portuguesas, por sua vez, pouco se favoreciam com o montante tributado, visto que a maior parcela dos valores arrecadados ficava nas mãos dos particulares. Como

\footnotetext{
18 Estes eram os principais impostos incidentes sobre a produção e os que maiores somas rendiam ao Erário. Adiante explanaremos a temática com mais detalhe;

19 Acerca da arrecadação dos dízimos encontramos algumas divergências quanto ao método de recolhimento. O relato de Vieira apresentado acima demonstra ser um recolhimento in natura. Entretanto, na pesquisa apresentada por Prado Jr, é enfatizada a arrecadação do dízimo em espécie: “O dízimo sempre correu parelhas, entre os grandes flagelos da administração da colônia (...). O que dele sofreu a população não é fácil descrever. Já por si, trata-se de um tributo pesado: 10\% da produção bruta. Mas isto ainda é o de menos; muito pior foi a forma com que se cobrava, em espécie, em vez de ser in natura, como se devia entendê-lo e como fora efetivamente no passado remoto da monarquia. Obrigavase o produtor a satisfazer em dinheiro o valor de uma parte apreciável de um produto ainda não realizado, e que era mais ou menos arbitrariamente avaliado pelos "dizimeiros". Compreende-se o efeito catastrófico desta cobrança numa economia como a da colônia, em que a moeda escasseava e o crédito era praticamente inexistente, pelo menos para a maior parte das necessidades e das pessoas" (PRADO JR, 2011, p. 342). No entanto, o contexto econômico apresentado no Brasil Colônia nos leva a sustentar que a cobrança do dízimo, assim como dos demais tributos, era feita in natura, sendo em espécie o pagamento que os dizimeiros faziam à Coroa.
} 
resultado, a estrutura arrecadatória instalada inibia o nível de produção ao oferecer plenos poderes aos arrecadadores, poderes estes usados sem comiseração alguma e provocando um caótico cenário de devastação por onde adentrava.

Como vimos, a prática arrecadatória em si gerava prejuízos aos produtores, em especial os pequenos, ao permitir os desmandos por parte dos cobradores de tributos. Contudo, o que pode ser afirmado acerca dos tributos em si? Estaríamos diante de uma arrecadação que respeitava a capacidade contributiva do cidadão, havendo o predomínio da tributação progressiva, ou, pelo contrário, seria possível constatar a existência de um mecanismo tributário no qual a regressividade era predominante? Adiante discutiremos os tributos e suas características.

\section{Tributos - Dízimo, o “doce” fel}

Antes de iniciarmos a discussão sobre os tributos em si, necessitamos esclarecer quanto a dificuldade em compilar as informações para o período exposto. Como já explanado sobre a administração fazendária, havia falta de simetria e organização, tanto na arrecadação quanto no registro do que fora arrecadado. Ademais, como bem colocado por Castro,

A principal dificuldade que oferece o estudo do nosso sistema tributário no período colonial, consiste na absoluta ausência de qualquer organização sistemática, não havendo ao menos uma legislação uniforme. Não vigorava nas colônias a legislação tributária da metrópole; e nas próprias colônias não eram cobrados os mesmos impostos. (CASTRO, 1989, pp. 13-14)

Tal afirmação acerca das pesquisas tributárias para o período colonial também está presente nas considerações iniciais apresentadas por Ângelo Carrara, em seus estudos sobre as Receitas e despesas da Real Fazenda no Brasil, século XVII:

A apresentação das conjunturas financeiras do período em estudo exige uma advertência prévia. Como se mencionou anteriormente, a dispersão da documentação das provedorias em meio à documentação de natureza administrativa geral (provisões, ordens, bandos, alvarás, ofícios, requerimentos etc.) somada à falta de um arranjo orgânico das séries documentais tem criado um quadro hostil ao tratamento sistematizado dos dados. (...) Deve também ser lembrado que a documentação particular dos contratadores - especialmente dos dízimos - parece estar irremediavelmente perdida. (CARRARA, 2009, p. 79) 
Isto posto, procuraremos reproduzir os resultados das análises consolidadas por pesquisadores da temática, utilizando suas obras para a construção da narrativa e reflexão sobre como se deu a tributação na Colônia. Consequentemente, trataremos dos principais tributos do período, fugindo-nos as particularidades que possivelmente ocorreram.

Diante do cenário econômico apresentado: uma terra aonde as trocas monetárias eram praticamente inexistentes, a produção de itens de subsistência ocorria na localidade que seriam consumidos e a economia era dependente da monocultura exportadora, como pensar em uma estrutura tributária que se beneficiasse desta conjuntura? Em decorrência desta realidade, "é bem de se ver que nesse período em que só se podia contar com o produto da terra, naturais eram os impostos lançados sobre a produção". (MACHADO, 1922, p. 05) Sendo assim, tem-se a produção e a Alfândega como os principais fatos geradores de impostos no Brasil Colônia nos séculos XVI e XVII.

Retomando os estudos de Castro, torna-se possível a constatação acerca dos mais importantes mecanismos tributários utilizados:

A tributação consistia em impostos de importação, consumo e exportação; eram impostos sobre a circulação de valores comerciais. Deles estavam isentos o trabalho e o capital, que não eram gravados nem direta nem indiretamente. A propriedade urbana, a propriedade rural e o capital auferiam as vantagens de isenção tributária. (CASTRO, 1989, p. 14)

Sobre a relação apresentada pelo autor, precisamos efetuar alguns esclarecimentos no tocante à nomenclatura utilizada. Castro menciona os impostos alfandegários e os de consumo, além de enaltecer que estes eram impostos sobre a circulação de valores comerciais $^{20}$. Na realidade, a tributação interna na Colônia, nos séculos XVI e XVII, consistia, predominantemente, na ida do cobrador de tributos à fazenda ou localidade produtora. Além disso, como amplamente discutido acima, a cobrança era feita in natura, ocorrendo assim a incidência tributária sobre a produção e não propriamente sobre o consumo. No entanto, se considerarmos que o ônus tributário iria recair no preço final da mercadoria, estamos diante de uma tributação indireta sobre o consumo, como bem colocado por Mauro:

\footnotetext{
${ }^{20} \mathrm{O}$ estudo do autor abrange os séculos XVI ao XVIII, englobando também a mineração. No próximo tópico discutiremos a tributação praticada no período da mineração, havendo nesta época a cobrança de impostos sobre as mercadorias que circulavam internamente na Colônia. Contudo, a mesma prática não é observada no período ora em análise. Salientemos, no entanto, que havia a entrada e saída de mercadorias da Colônia, sendo esta atividade considerada circulação de valores comerciais.
} 
Impostos sobre a produção ou impostos sobre o consumo, os impostos brasileiros, no final de contas muito pesados, incidiram muito sobre os preços. (MAURO, 1969, p. 203)

Por conseguinte, podemos afirmar que desde o início da colonização em solos brasileiros optou-se por uma tributação indireta sobre o consumo, aonde a produção era pesadamente onerada e os preços impactados. De posse destas informações, passemos à análise dos tributos mais importantes do período.

O principal imposto interno do Brasil Colônia era o dízimo, havendo a incidência de $10 \%$ sobre a mercadoria produzida, seguido do quinto, que tributava a produção em $20 \%{ }^{21}$. Referente às suas origens, assim como na implantação da função do Contratador, a cobrança do dízimo e quinto também é uma prática portuguesa que remonta tempos imemoriais da civilização:

O tributo das sociedades antigas que mais raízes deixou foi o dízimo, que tem suas origens quase perdidas, pois entre os hebreus, segundo a Lei Mosaica, deviam ser tributados os dízimos e primícias para o culto divino. Entre muitos povos antigos, prevalecera o costume de ofertar a décima parte dos bens da terra para o culto da divindade, ou seja, ao príncipe e ao sacerdote que o representava ou o ministrava. Dessa maneira, os dízimos estiveram presentes em quase todas as sociedades do Mundo Antigo. Daí que, no Egito, pagavam-se ao príncipe os dízimos dos produtos da terra, no tempo dos Ptolomeus, e provavelmente também na época dos antigos Faraós. Quando José anuncia ao Faraó sete anos de abundância a que se seguirão sete outros de carestia, ele the recomenda receber durante os sete primeiros anos o quinto dos produtos da terra, isto é, o duplo dízimo, na previsão do período seguinte, durante o qual não seriam possíveis os impostos. (AMED; NEGREIROS, 2000, p. 21)

Deste modo, Portugal segue fielmente a tradição em tributar os produtos da terra, promovendo o recolhimento da décima parte de tudo o que era produzido. Além disso, aproveitando-se da profecia acima mencionada, instaurou também a cobrança do quinto como algo permanente, e não somente por um período pré-determinado no qual haveria possível crise de produção.

Sobre a história do dízimo em si, não temos como intuito reconstruir todas as etapas pelas quais o imposto atravessou até passar aos domínios da Igreja Católica. No entanto,

\footnotetext{
${ }^{21} \mathrm{Na}$ realidade, observaremos uma maior incidência do quinto no período da mineração. Nos séculos XVI e XVII ocorreu, principalmente, a arrecadação por meio do dízimo, sendo a produção do açúcar aquela que mais contribuiu para o fato gerador tributário.
} 
interessa-nos entender como se deu a transferência do dízimo das mãos da Igreja para a Coroa lusa.

O direito de Portugal arrecadar os dízimos relaciona-se aos direitos do padroado adquirido em tempos de lutas militares e da Reconquista, no século XII. As Ordens de cavalaria de São Tiago da Espada, a de São Bento de Avis e a dos Templários, esta última extinta em 1310 e tendo como herdeira a Ordem de Cristo, foram as Ordens militares responsáveis pelas vitórias lusas.

Com o passar do tempo a Ordem de Cristo tornou-se a mais importante e poderosa Ordem militar portuguesa, sendo feita, por essa razão, a transferência dos rendimentos do dízimo da Igreja à mencionada Ordem. Os reis de Portugal, enquanto Grão-Mestres da Ordem de Cristo, tinham o direito de cobrar os dízimos em suas posses ultramar:

Os papas a ela concederam, na segunda metade do século $\mathrm{XV}$, em reconhecimento à sua atuação como propagadora da fé cristã, a instituição do direito do padroado. Mais tarde, já no século XVI, acoplou-se o poder religioso-militar das ordens com o poder régio. (SALGADO, 1985, p. 113)

Em contrapartida, seria incumbência da Coroa suprir as necessidades da Igreja, principalmente financeiras:

Lembremos unicamente o padroado, concedido ao rei de Portugal e nas suas possessões ultramarinas (...). Cabia ainda ao monarca - por concessão, como vimos, à Ordem de Cristo - a percepção dos dízimos, que é um tributo eclesiástico destinado originalmente à manutenção do clero. Em compensação, competia à Coroa prover a esta manutenção, e tal é o objetivo das côngruas, isto é, subvenções pecuniárias aos membros do clero. (PRADO JR., 2011, p. 352)

Sem embargo, é incontestável a importância financeira que o dízimo ofereceu aos lusos, a Coroa muito se beneficiou do direito de arrecadá-lo. Como visto, este foi o principal tributo existente no Brasil no período analisado, havendo a incidência tributária de $10 \%$ sobre tudo o que se produzia em solos brasileiros. De fato, tal desempenho do dízimo foi proporcionado pela grande produção açucareira existente, sendo essa a maior contribuição que a monocultura voltada para a exportação gerou ao Erário e, principalmente, aos coletores de impostos, os Dizimeiros.

Desta maneira, os contratos do dízimo, por serem os que mais interessavam aos arrematadores, constituem fonte de pesquisa para Carrara. Por meio de seus estudos o autor buscou compilar o valor do contrato dos dízimos nas Capitanias da Bahia, Pernambuco e Rio de Janeiro no decorrer do século XVII. Em suas pesquisas são 
demonstrados os montantes financeiros que os ditos contratos geraram aos cofres portugueses.

Sendo assim, estamos diante das evidências acerca da importância dos dízimos e, paralelamente, dos recursos recebidos pela Coroa. Contudo, nada podemos afirmar acerca do montante arrecadado em si, uma vez que parte da totalidade recolhida, como já sabido, constituía o lucro dos Dizimeiros, não estando computada nas análises do autor.

Ademais, por meio de suas pesquisas, Carrara obtém "um valor de dízimo em moeda, resultado de um contrato de arrendamento no qual é muito difícil decifrar em que medida a evolução dos contratos segue a evolução da produção e dos preços". (CARRARA; SANTIRÓ, 2013, p. 172) Nas duas primeiras décadas dos Seiscentos os seguintes números são apresentados:

Entre 1607 e 1610, a receita total dos dízimos do Estado do Brasil oscilou entre 42:000\$000 e 43:036\$000. Bahia e Pernambuco juntos eram responsáveis por $85 \%$ desse total $(18: 356 \$ 000$ e 17:360\$000 réis, respectivamente). Contudo, em 1613 a receita saltou para 54:000\$000 réis, mas a participação da Bahia diminuiu: os dízimos nesse ano permaneceram na casa dos 18:000\$000. Obviamente, é a Pernambuco que se deve atribuir esta elevação. (CARRARA, 2009, pp. 94-95)

Tais constatações auxiliam no entendimento e na relação existente entre a cultura canavieira e a arrecadação tributária na Colônia. Por meio destes estudos é possível quantificar uma realidade já amplamente debatida no decorrer deste capítulo acerca da importância do açúcar em solos brasileiros, ocupando-nos, no momento, da análise dos fatos geradores de tributos. Bahia e Pernambuco eram, no período em pauta, as Capitanias que mais recursos tributários geravam para o Reino e Contratadores. Ademais, eram estes territórios os principais produtores de açúcar nos séculos iniciais da colonização.

Sendo assim, era a tributação incidente sobre a produção açucareira o mais importante mecanismo de recolhimento interno de impostos. Não obstante, dada a representatividade que o cultivo da cana e produção de açúcar ofereciam à economia, toda e qualquer flutuação existente na produção e/ou preços internacionais do açúcar impactava diretamente a arrecadação dos dízimos. Além disso, não podemos deixar de contextualizar, como bem lembrado por Carrara, as situações de desequilíbrios internos ocorridos na Colônia, por serem eles também fatores determinantes para o recolhimento tributário: 
A partir da segunda metade da década de 1620 o vento favorável que animara o aumento das receitas (leia-se: dízimos), começou a mudar de direção. Entre 1619 e 1622 só os dízimos das capitanias da Bahia e suas anexas alcançaram a cifra de 26:800\$000 réis anuais. Em 1623 despencaram para 15:200\$000 réis. A mesma queda verificou-se em Pernambuco e decorria, segundo Joseph Joyce Jr., das epidemias, secas e baixa do preço internacional do açúcar. A partir de 1624, Stuart Schwartz acrescentaria a estes fatores a invasão holandesa. (CARRARA, 2009, p. 98)

Desta maneira, procuramos trazer luz aos fatos geradores e bases de incidência tributárias largamente utilizadas no período de ascensão do açúcar em solos brasileiros. Vimos que a arrecadação por meio dos dízimos sobre a produção constituiu-se no principal instrumento de recolhimento tributário. De fato, tomar para si $10 \%$ de tudo o que era produzido caracterizava uma oportunidade sem igual para o Reino e seus coletores de impostos. Sem embargo, podemos assegurar que se optou pela tributação da produção por ser esta a principal atividade econômica praticada na América portuguesa e que gerava maiores somas monetárias.

Além disso, devemos levar em consideração a estrutura administrativa arrecadatória, ou a falta dela, implantada. Diante de um cenário no qual os arrecadadores locomoviam-se à localidade produtora para realizarem o recolhimento tributário, como pensar em uma estrutura na qual a tributação sobre a produção não seria a principal fonte de recursos de impostos? Caso fosse possível tributar as rendas e riquezas, como se daria o controle e averiguação de tais bases de incidência? Como se daria o recolhimento uma vez que a moeda metálica era praticamente inexistente e a tributação in natura foi a solução encontrada?

Não nos parece haver alternativas, ao menos não neste momento, que não a tributação interna sobre a produção. A quantidade produzida era incontestável ${ }^{22}$, estava diante dos olhos do cobrador de tributos e bastava a ele retirar para si o percentual que lhe cabia e que lhe era de direito, direito este outorgado pelo Rei.

Não pretendemos neste momento esgotar o assunto, muito menos negligenciar outras fontes tributárias internas que não o dízimo, elas existiram. Todavia, assim como o dízimo,

\footnotetext{
22 Lembremos que o Contratador efetuava, rotineiramente, de uma única vez a cobrança tributária de todo o período estipulado no contrato. Neste contexto, podemos questionar a quantidade a ser tributada. Contudo, o que desejamos retratar neste momento é que a mercadoria a ser tributada estava diante dos olhos do dizimeiro, favorecendo a averiguação do montante a ser transferido para este senhor. Tal averiguação e controle não seria possível se o fato gerador fosse, por exemplo, a riqueza do produtor, pois não havia meios de averiguar o montante desta riqueza.
} 
sua característica também era tributar a produção e o consumo, por ser essa a base tributária disponível. Destarte, também ocorria a incidência de tributos extras, como colocado por Schwartz:

Os senhores de engenho baianos podiam queixar-se, em 1673, de que, além do dízimo e de outros impostos sobre a produção, pagavam também 380 réis por caixa de açúcar remetida para o "sustento da infantaria", ou seja, a manutenção da guarnição local, e um adicional de 540 réis em Lisboa para pagar os custos da frota. (SCHWARTZ, 1988, pp. 164-165)

Feitas essas considerações pretendemos novamente frisar o fato de, por mais que houvesse outros tributos internos incidentes sobre a produção, o dízimo era, incontestavelmente, o principal instrumento de arrecadação interna nos séculos XVI e XVII.

No entanto, não somente sobre a produção de produtos primários ocorria o recolhimento tributário. Por meio da exportação e da importação de mercadorias ocorria a oportunidade em tributar a Alfândega. As terras brasileiras, sendo propriedade de Portugal, não tinham outra opção que não enviar sua produção para o Reino e receber somente da Metrópole os produtos necessários para a população aqui instalada.

Desta maneira, Portugal exercia o monopólio comercial com sua Colônia e o controle alfandegário acerca de toda mercadoria que se destinava ao Brasil ou era dele originária. Obviamente não estamos considerando os casos de contrabando ocorridos. Diante desta realidade, muito natural ao Erário aproveitar-se da circulação de mercadorias que ocorria nas Alfândegas e promover a taxação por meio dos impostos de exportação e importação.

Assim como no caso da tributação sobre a produção, havendo o argumento sobre ser o dízimo um imposto que estimulava a produção, também ocorria a defesa da tarifa alfandegária, alegando-se ser este um instrumento de compensação ao monarca por propiciar a defesa das mercadorias transladadas:

Procurava-se justificar as tarifas de importação e exportação, afirmando que as mesmas constituíam um prêmio dado ao rei pela proteção que o Estado confere às mercadorias durante o embarque e desembarque, defendendo-as contra assaltos de piratas e contra roubos. Além disso, os direitos sobre a exportação são justos, porque permitem a outro país o uso do que o trabalho nacional criou. (VIEIRA, 1973, p. 348)

Sendo assim, procura-se justificar a aplicação e legalidade dos tributos alfandegários sobre toda circulação de mercadorias ocorrida nos portos. Seja como meio de retribuição ao Rei ou extrair de outras nações parte de suas riquezas por lhes conceder a oportunidade 
de usufruto de mercadorias que não produziram, os impostos de exportação e importação também compuseram a estrutura arrecadatória instalada no Brasil Colônia. Sobre os impostos de exportação, observamos o seguinte:

Os produtos brasileiros exportados para a metrópole eram tributados em $10 \%$ ad valorem, os dízimos de exportação, recolhidos na colônia; mas, como eram incluídos no preço das mercadorias, eram portugueses, em última análise, os que pagavam o tributo. (VIEIRA, 1973, p. 348)

Diante desta constatação notamos que o dízimo não se aplicava somente à produção de mercadorias, sobre a exportação ocorria novamente a incidência deste imposto. No entanto, o que poderíamos afirmar sobre a tributação das mercadorias que adentravam a Colônia, estaríamos diante da mesma ferramenta de recolhimento? Novamente VIEIRA faz contribuições para o entendimento da questão:

Quanto aos impostos de importação, já naquela época se argumentava por função evitar que os produtos estrangeiros concorressem com os nacionais. (...) Acontecia, porém, que as importações do Reino, entradas na colônia, não representavam concorrência de produtos estrangeiros aos nacionais, porque a política portuguesa considerava as suas colônias como extensão do território metropolitano, e, portanto, parte integrante da nação. Além disso, proibia-se que o Brasil tivesse produções agrícolas ou industriais concorrentes das portuguesas. (...) Os dízimos de importação, $10 \%$ ad valorem, tinham apenas a finalidade fiscal de aumentar as rendas do Erário, (...) recaíam sobre todos os produtos trazidos para o Brasil. (VIEIRA, 1973, p. 348)

Desta maneira, os impostos alfandegários, comumente chamados de dízima da Alfândega, constituíram outra importante ferramenta de arrecadação do Erário. No entanto, ao contrário do dízimo sobre a produção, que continha a mesma característica onde fosse recolhido, não podemos fazer a mesma afirmação sobre a dízima da Alfândega. De acordo com os estudos de Carrara para as Capitanias da Bahia e Pernambuco, há diferenças entre a dízima aplicada nas ditas localidades. Na Capitania da Bahia observa-se:

Este rendimento, que tem origem como direito real pelas Ordenações do Reino e da Fazenda, teve instituição particular nesta capitania logo que ela foi incorporada na Coroa, e se estabeleceu pelo capítulo IV do regimento que deu o Senhor rei D. João III ao primeiro provedor-mor da Fazenda Real desta capitania em 17 de dezembro de 1548. Este direito se ordenou que se cobrasse em espécie, rematando-se depois em leilão público. Mas depois, por alguns acontecimentos e pela resolução de Sua Majestade de 27 de maio de 1714, e edital do marquês de Anjeja, ...vice-rei deste Estado, de 17 de julho do dito ano se estabeleceu a sua cobrança em dinheiro ${ }^{23}$, que

${ }^{23} \mathrm{O}$ pagamento em espécie é caracterizado pelo pagamento em dinheiro. Desta maneira, cremos haver neste ponto algum equívoco quanto aos termos utilizados, desejando o autor relatar que inicialmente o pagamento era feito in natura, ou seja, um percentual pago em mercadorias. 
consiste em $10 \%$ de todas as fazendas que entram. (...) A dízima das Alfândegas parece ter sido efetivamente cobrada e arrecadada durante a União Ibérica [1580-1640 - C.S]. Há menção a seu rendimento até 1640, tendo desaparecido por completo até sua reaparição no princípio do século XVIII em razão da intensa movimentação portuária provocada pela importação de mercadorias por conta da produção aurífera. (CARRARA, 2009, p. 198)

Portanto, de acordo com o relatado pelo autor, a dízima da Alfândega incidente nos portos da Bahia recaía sobre as mercadorias entrantes, sobre a importação, havendo a cobrança de $10 \%$ ad valorem. Os conhecimentos da conjuntura da época nos levam a crer que inicialmente o pagamento era feito in natura, passando a ser cobrado em dinheiro posteriormente, conforme exposto. Ademais, como bem colocado pelo autor, este imposto ganhou considerável representatividade no período da mineração, por ser este um período da história brasileira que impulsionou intensa atividade econômica e fluxo migratório para o Brasil. Discutiremos tais circunstâncias em tópico vindouro.

Contudo, as mesmas características existentes na Bahia, acerca da dízima da Alfândega, não são observadas na Capitania de Pernambuco. Neste território ocorria a incidência tributária sobre as mercadorias exportadas: "Dízima da Alfândega na Praça do Recife, este tributo, correspondente à tarifa de $10 \%$ sobre as fazendas despachadas na Alfândega (...), e foi estabelecido pela ordem régia de 4 de fevereiro de 1711”. (CARRARA, 2009, p. 232) Deste modo, a mesma nomenclatura tributária possuía, neste caso, incidências divergentes, embora ambas fossem destinadas ao recolhimento tributário alfandegário.

Neste momento retomamos as considerações de Castro, apontadas acima, quanto às dificuldades encontradas em se estudar a tributação no período colonial devido à falta de legislação uniforme e práticas tributárias divergentes existentes entre as Capitanias. Estamos diante de um caso concreto desta realidade sinalizada pelo autor. A própria dízima da Alfândega, um dos principais impostos do período, ora tributava a importação e em outro momento incidia sobre a exportação.

Destarte, sob a ótica da Coroa, não interessava se a tributação recairia sobre a produção, a exportação e/ou a importação, o dízimo e a dízima eram os principais mecanismos de arrecadação observado nos dois séculos iniciais da história brasileira, tributando à alíquota de $10 \%$ tudo o que fosse possível. Tais ferramentas tributárias foram as soluções encontradas pelos lusos a fïm de intensificarem a arrecadação fiscal. É correto afirmar que ocorreram outras formas de arrecadação, no entanto, a tributação sobre a produção e 
os impostos alfandegários ofereceram ao Erário e seus representantes particulares as maiores oportunidades de transferência de recursos dos produtores e comerciantes para as mãos do Estado e dos Contratadores.

Além disso, podemos considerar que estes mecanismos tributários não levavam em consideração a capacidade contributiva do cidadão. Não havia diferença entre o pequeno e o grande produtor, o tímido comerciante e o pujante homem de negócios que concentrava em suas mãos parcelas consideráveis das importações e/ou exportações ocorridas no Brasil. Todos estavam sujeitos à mesma alíquota tributária. Ademais, como já observado, os Rendeiros eram isentos de tributos e alguns custos logísticos, ou seja, estamos diante de uma estrutura tributária que beneficiava aqueles que possuíam maiores condições econômicas.

Contudo, o século XVIII, por meio da descoberta e exploração das minas auríferas e de diamantes, passa a contar com uma nova dinâmica. Neste novo contexto, a atividade econômica interna ganha destaque e a circulação de mercadorias em solos brasileiros, entre as Capitanias, adquire vida, fôlego e notoriedade. Diante desta nova realidade haveria a oportunidade em reformular a atividade tributária? Em caso afirmativo, estaríamos diante de uma nova característica ou somente alguns incrementos sobre a estrutura já existente?

\section{$\underline{\text { A Tributacão sobre a Circulação, Século XVIII }}$}

Assim como na análise do período do açúcar e seus tributos, nos estudos acerca do ouro procuramos seguir a mesma estrutura textual. Desta maneira, inicialmente abordaremos as características econômicas e as transformações observadas no território brasileiro oriundas desta atividade. Posteriormente examinaremos as questões fiscais, a adaptação da estrutura administrativa arrecadatória e as novas ferramentas tributárias condizentes com o novo modelo econômico instaurado.

Todavia, devemos salientar que nossa narrativa não se ocupará das atividades principais em si, ou seja, a extração do ouro e o montante que esta prática gerou. Também não desejamos nos alongar nas discussões sobre a arrecadação do quinto, da capitação e da 
derrama, temáticas estas já longamente debatidas por respeitados estudiosos. O objeto deste tópico centrar-se-á em discorrer sobre as ramificações da economia mineratória, o desenvolvimento do mercado interno, a interconexão entre as várias regiões do Brasil e os tributos oriundos da circulação de mercadorias que adentravam as regiões auríferas.

\section{Enfim, o ouro...}

Ambicionava-se, desde o início da colonização, a descoberta do ouro em solos da América portuguesa, assim como ocorreu na América espanhola. Entretanto, para o bem ou para o mal, a Coroa lusa trilhou caminhos opostos de seu vizinho. Chegou-se até mesmo a cogitar que o Brasil não fora abençoado com o estimado metal. No entanto, em fins do século XVII os ventos passam a soprar em outra direção e a sorte começa a mudar. Jazidas de ouro e pedras preciosas são encontradas no território da hoje denominada Minas Gerais. Demais jazidas também foram encontradas em outras localidades, como Bahia, Goiás e Mato Grosso. Todavia, são os solos de Minas Gerais os mais bemaventurados. Tal descoberta trouxe uma nova roupagem para a Colônia portuguesa e ofereceu à Coroa oportunidade de ganhos consideráveis.

Nos dois séculos iniciais da história brasileira ocorreu a concentração da produção açucareira e a predominância da arrecadação de impostos sobre a produção, principalmente por meio dos dízimos. Porém, em fins do século VXII a economia canavieira estava bem distante de seus tempos áureos. A concorrência enfrentada com outros produtores, principalmente os holandeses e o açúcar antilhano, colocara as finanças lusas em situação de penúria.

Quando tudo parecia perdido e o desalento tomara conta do Reino e da Colônia, a descoberta do ouro propiciou novos ânimos e promoveu uma nova configuração para a dinâmica econômica, migratória e tributária brasileira.

Em fins do século XVII e início do XVIII profundas transformações são observadas no Brasil, ocorrendo um substancial crescimento populacional e a interconexão econômica entre as diversas regiões. Desta maneira, internamente a circulação de mercadorias ganha papel de destaque na atividade comercial e no fomento do consumo colonial, definindo, assim, uma nova maneira de tributação. Além dos impostos sobre a produção, passamos 
a observar, em concomitância com os primeiros, a tributação sobre pessoas, animais e mercadorias destinadas às terras auríferas e de diamantes.

No tocante ao crescimento populacional, o que se observa neste período é um intenso fluxo de migração para as regiões auríferas. Muitos imigrantes de Portugal optaram por atravessar o Atlântico no anseio de enriquecer por meio da descoberta de ouro e pedras preciosas. Acerca deste evento, Celso Furtado explana:

Com efeito, tudo indica que a população colonial de origem europeia decuplicou no correr do século da mineração. Cabe admitir, demais, que o financiamento dessa transferência de população em boa medida foi feito pelos próprios imigrantes, os quais eram pessoas de pequenas posses que liquidavam seus bens na ilusão de alcançar rapidamente uma fortuna no novo eldorado. (FURTADO, 2007, pp. 119-120)

Desta maneira, o fluxo migratório para a Colônia passa a adquirir uma nova característica, aonde ocorre a chegada massiva de uma população livre disposta a iniciar um novo ciclo de sua vida. Ciclo este alimentado pela esperança de dias melhores, iluminado e guiado pelo brilho do ouro.

Contudo, não somente os portugueses que habitavam a Metrópole eram movidos por este sonho. Muitos que na Colônia já estavam instalados passaram a abandonar suas terras à procura de melhores condições de vida. "De Piratininga a população emigrou em massa, do Nordeste se deslocaram grandes recursos, principalmente sob a forma de mão-de-obra escrava, (...). O facies da colônia iria modificar-se fundamentalmente”. (FURTADO, 2007, p. 118) Sim, o facies modificou-se e promoveu o deslocamento do centro econômico colonial para a região das minas. Não somente a população livre moveu-se para a exploração do ouro, mas também a população escrava e com ela toda a oportunidade de maiores possibilidades de encontrar o tão ambicionado metal precioso. Posteriormente, observamos o deslocamento da capital da Colônia de Salvador para o Rio de Janeiro, tornando-se este o principal porto do país:

As transformações provocadas pela mineração deram como resultado final o deslocamento do eixo econômico da colônia, antes localizado nos grandes centros açucareiros do Nordeste (Pernambuco e Bahia). A própria capital da colônia (...) transfere-se em 1763 da Bahia para o Rio de Janeiro. As comunicações mais fáceis das minas para o exterior se fazem por este porto, que se tornará assim o principal centro urbano da colônia. (PRADO JR., 1995, p. 64)

Tal dinâmica e interesse pela região aurífera pode ser entendida também pela exigência mínima de capital inicial daqueles que desejavam explorar as minas, quando comparado 
ao montante necessário para a constituição de um engenho açucareiro, por exemplo. Este fator favoreceu a entrada de um maior contingente de pessoas para a atividade extrativista. Neste contexto, o grande e o pequeno explorador obtinham oportunidades de garimpar, sendo-lhes entregues áreas correspondentes aos seus recursos:

$\mathrm{Na}$ economia mineira, as possibilidades que tinha um homem livre com iniciativa eram muito maiores. Se dispunha de recursos, podia organizar uma lavra em escala grande, com cem ou mais escravos. Contudo, o capital que imobilizava por escravo ou por unidade de produção era bem inferior ao que correspondia a um engenho real. Se eram reduzidos os seus recursos iniciais, podia limitar sua empresa às mínimas proporções permitidas pela divisibilidade da mão-de-obra, isto é, a um escravo. Por último, se seus recursos não lhe permitiam mais que financiar o próprio sustento durante um período limitado de tempo, podia trabalhar ele mesmo como faiscador. Se lhe favorecia a sorte, em pouco tempo ascenderia à posição de empresário. (FURTADO, 2007, p. 121)

Diante desta realidade, ocorreu a concentração dos recursos e trabalhos na extração de ouro e diamantes. Como consequência, o panorama observado na região das minas era de pouco ou quase inexistente cultivo agropecuário. Além do pouco interesse que havia entre a população local nesta atividade, outra característica predominante era a alta rotatividade da área que estava sendo garimpada, uma vez que era o ouro de aluvião ${ }^{24}$ o encontrado em solos brasileiros. Sendo assim, como pensar em constituir uma plantação ou criação de bovinos em uma região que em pouco tempo seria abandonada? Tal cenário e tomada de decisão gerou severas sequelas para a população instalada na região, o brilho do ouro quase sempre era acompanhado pela sombra da fome:

Sendo a lucratividade maior na etapa inicial da mineração, em cada região, a excessiva concentração de recursos nos trabalhos mineratórios conduzia sempre a grandes dificuldades de abastecimento. A fome acompanhava sempre a riqueza nas regiões do ouro. (FURTADO, 2007, p. 121)

O cenário de escassez foi suavizado, mas não mitigado, pelas demais regiões do país que se ocuparam em produzir alimentos e mercadorias para suprir as necessidades de consumo e sobrevivência daqueles que se concentravam na exploração aurífera. É neste contexto que começamos a observar as ramificações econômicas da atividade mineradora para outras localidades da Colônia:

\footnotetext{
${ }^{24} \mathrm{O}$ ouro de aluvião caracteriza-se por estar depositado na superfície dos leitos dos rios. Desta maneira, era relativamente fácil a sua extração quando comparada com a necessidade de técnicas mais sofisticadas para a retirada do ouro localizado em níveis mais profundos do solo. Além disso, a exploração do ouro de aluvião traz como consequência a alta rotatividades das regiões garimpadas, uma vez que findo este ouro ocorre a necessidade de deslocamento para outra área ainda inexplorada.
} 
O aparecimento de um núcleo populacional denso, de alto poder aquisitivo, no sertão do Brasil, provocou uma verdadeira efervescência econômica, bem como o nascimento de correntes abastecedoras que, partindo das cidades, vilas e sertões do Brasil, convergiram para as minas gerais. Cada região procurou oferecer às populações mineradoras os artigos de que dispunha; em seguida, animadas com o ouro que tais fornecimentos propiciavam, aumentaram ao máximo sua capacidade produtiva. (ZEMELLA, 1990, p. 29)

Como toda a troca de mercadorias se dava através do pagamento em ouro, ledo engano supor que os preços não eram impactados e inflacionados. "A elevação dos preços dos alimentos e dos animais de transporte nas regiões vizinhas constituiu o mecanismo de irradiação dos benefícios econômicos da mineração”. (FURTADO, 2007, p. 121) Desta maneira, as demais localidades que comercializavam com as regiões auríferas obtiveram a oportunidade de ganhos antes inimagináveis, restando aos habitantes de Minas Gerais submeterem-se aos elevados preços praticados. Tomemos como exemplo o impacto nos preços da atividade pecuarista:

A pecuária, que encontrava no sul um hábitat excepcionalmente favorável para desenvolver-se - e que, não obstante sua baixíssima rentabilidade, subsistia graças às exportações de couro -, passará por uma verdadeira revolução com o advento da economia mineira. O gado do sul, cujos preços haviam permanecido sempre em níveis extremamente baixos, comparativamente ao que prevaleciam na região açucareira, valoriza-se rapidamente e alcança, em ocasiões, preços excepcionalmente altos. $\mathrm{O}$ próprio gado do Nordeste, cujo mercado definhava com a decadência da economia açucareira, tende a deslocar-se em busca do florescente mercado da região mineira. (FURTADO, 2007, p. 121)

Deste modo, a riqueza gerada pelo ouro passou a desenvolver economicamente as localidades exteriores aos limites da região das minas que se especializaram em suprir as necessidades dos exploradores e da população ali instalada. Todavia, não apenas os frutos positivos advindos do comércio com as minas foram sentidos pela população que vivia nas cidades e vilas abastecedoras, efeitos deletérios também se fizeram presentes nestas comunidades:

Quando foi descoberto o ouro, não estavam as vilas paulistas em condições de suprir as necessidades dos mineradores das Gerais; entretanto, a febre da especulação fez com que tudo que houvesse para suprir às próprias vilas paulistas fosse levado para as minas. A consequência foi a alta dos preços, a escassez de mantimentos e mesmo a carência de gêneros alimentares em todo o Planalto. Valendo uma rês em São Paulo $2 \$ 000$, por ela pagavam os mineradores 50 oitavas de ouro. Essa diferença fez com que todo o gado para o corte fosse encaminhado para as Gerais. (ZEMELLA, 1990, p. 57) 
Ainda sobre as dificuldades enfrentadas por São Paulo no tocante ao abastecimento das Gerais, temos:

As vilas paulistas sacrificaram seu próprio abastecimento, para mandar às minas boiadas, toucinho, aguardente, açúcar, panos, calçados, drogas e remédios, trigo, algodão, enxadas, almocafres e artigos importados, como sal, armas, azeite, vinagre, vinho, aguardente do reino, etc. (ZEMELLA, 1990, p. 59)

Contudo, não destaquemos somente o ônus vivenciado por São Paulo. Aos tropeiros desta localidade foi possível desenvolver um intenso comércio com a região mineratória, para tal, desbravando demais localidades brasileiras a fim de suprir as demandas oriundas da população que habitava as minas:

Assim vemos que, a princípio, os habitantes de Piratininga limitaram-se a mandar para as Gerais as sobras de sua minguada produção. Depois, atraídos pelos gordos lucros, intensificaram essa produção, com o fito de vender cada vez mais, ainda que fosse com sacrifício dos consumidores locais. Em seguida, não contentes com isso, foram buscar, em regiões por vezes distanciadas, tudo aquilo de que os mineiros careciam e que eles mesmos não podiam produzir. Não tendo, por exemplo, bastante gado bovino para fornecer às minas, foram estabelecer currais e criar grossas boiadas nos campos de Paranaguá e Curitiba. Mas ainda, não tendo muares em número suficiente para transportar as cargas que demandavam as Gerais, nem podendo fornecer as bestas necessárias aos trabalhos das lavras e ao transporte do ouro, foram buscá-los nos descampados sulinos, nas planícies do Rio Grande do Sul, Uruguai, territórios Correntino e Entrerriano. (ZEMELLA, 1990, p. 60)

Acerca dos desdobramentos desta realidade, analisemos o impacto gerado no Rio Grande do Sul. Capitania de pouca expressividade no cenário econômico brasileiro nos séculos XVI e XVII, este território passa a adquirir uma importante atuação no novo desenho nacional. Suas tropas de muares e bovinos proporcionavam, por onde passavam, o crescimento da economia:

A região rio-grandense, onde a criação de mulas se desenvolveu em grande escala, foi, dessa forma, integrada no conjunto da economia brasileira. Cada ano subiam do Rio Grande do Sul dezenas de milhares de mulas, as quais constituíam a principal fonte de renda da região. Esses animais se concentravam na região de São Paulo, onde, em grandes feiras, eram distribuídos aos compradores que provinham de diferentes regiões. Desse modo, a economia mineira, através de seus efeitos indiretos, permitiu que se articulassem as diferentes regiões do sul do país. (FURTADO, 2007, p. 122)

Como resultado, tem-se início o processo de intercomunicação entre as localidades brasileiras, favorecendo e propiciando o mercado consumidor interno e auxiliando o desenvolvimento das demais regiões, não somente onde ocorria a atividade mineradora: 
De um modo geral, é todo este setor centro-sul que, graças em grande parte à mineração, toma o primeiro lugar entre as diferentes regiões do país; para conservá-lo até hoje. A necessidade de abastecer a população, concentrada nas minas e na nova capital, estimulará as atividades econômicas num largo raio geográfico que atingirá não somente as capitanias de Minas Gerais e Rio de Janeiro propriamente, mas também São Paulo. A agricultura e mais em particular a pecuária desenvolver-se-ão grandemente nestas regiões. (PRADO JR., 1995, pp. 64-65)

Intimamente ligada ao mercado consumidor das minas, a pecuária em muito foi favorecida pelas demandas advindas de Minas Gerais. Tal conjuntura auxiliou não só aqueles que estavam ligados à criação de gado, mas toda a cadeia desta atividade econômica:

[A mineração - C.S.] fez interdependentes as diferentes regiões, especializadas umas na criação, outras na engorda e distribuição, e outras constituindo os principais mercados consumidores. É um equívoco supor que foi a criação que uniu essas regiões. Quem as uniu foi a procura de gado que se irradiava do centro dinâmico constituído pela economia mineira. (FURTADO, 2007, p. 123)

Sendo assim, são as economias voltadas para o fornecimento de bens essenciais as mais favorecidas por esta nova dinâmica. Ademais, o isolamento das minas constituiu mais um fator importante para o desenvolvimento de outras atividades internas, além da agricultura e pecuária, pois tais mercadorias necessitavam ser conduzidas até o mercado consumidor. Consequentemente, o sistema de transporte foi estimulado, tendo-se mais uma ramificação da atividade aurífera:

Outra característica da economia mineira, de profundas consequências para as regiões vizinhas, radicava em seu sistema de transporte. Localizada a grande distância do litoral, dispersa e em região montanhosa, a população mineira dependia para tudo de um complexo sistema de transporte. A tropa de mulas constitui autêntica infraestrutura de todo o sistema. A quase inexistência de abastecimento local de alimentos, a grande distância por terra que deviam percorrer todas as mercadorias importadas, a necessidade de vencer grandes caminhadas em região montanhosa para alcançar os locais de trabalho, tudo contribuía para que o sistema de transporte desempenhasse um papel básico no funcionamento da economia. Criou-se, assim, um grande mercado para animais de carga. (FURTADO, 2007, p. 122)

Não obstante, era desafiador o transporte das mercadorias destinadas a Minas Gerais. Como bem colocado acima por Furtado, a geografia montanhosa pouco facilitava o percurso e longos eram os caminhos percorridos. Aliás, havia a preocupação em se evitar os contrabandos e sonegações fiscais, fazendo com que as autoridades estabelecessem os 
caminhos oficiais que interconectavam as regiões auríferas ao restante do país. A Estrada Real inicialmente foi constituída perpassando São Paulo, como demonstrado no Mapa 01.

O Caminho Velho e suas variantes representavam verdadeira epopeia para seus desbravadores, uma vez que as viagens duravam, em média, sessenta dias. O trajeto inicialmente estabelecido, além de pouco favorecer o tempo da viagem e a chegada das mercadorias aos centros consumidores, facilitava os desvios e contrabandos no decorrer do caminho.

\section{Mapa 1 - O Caminho Velho}

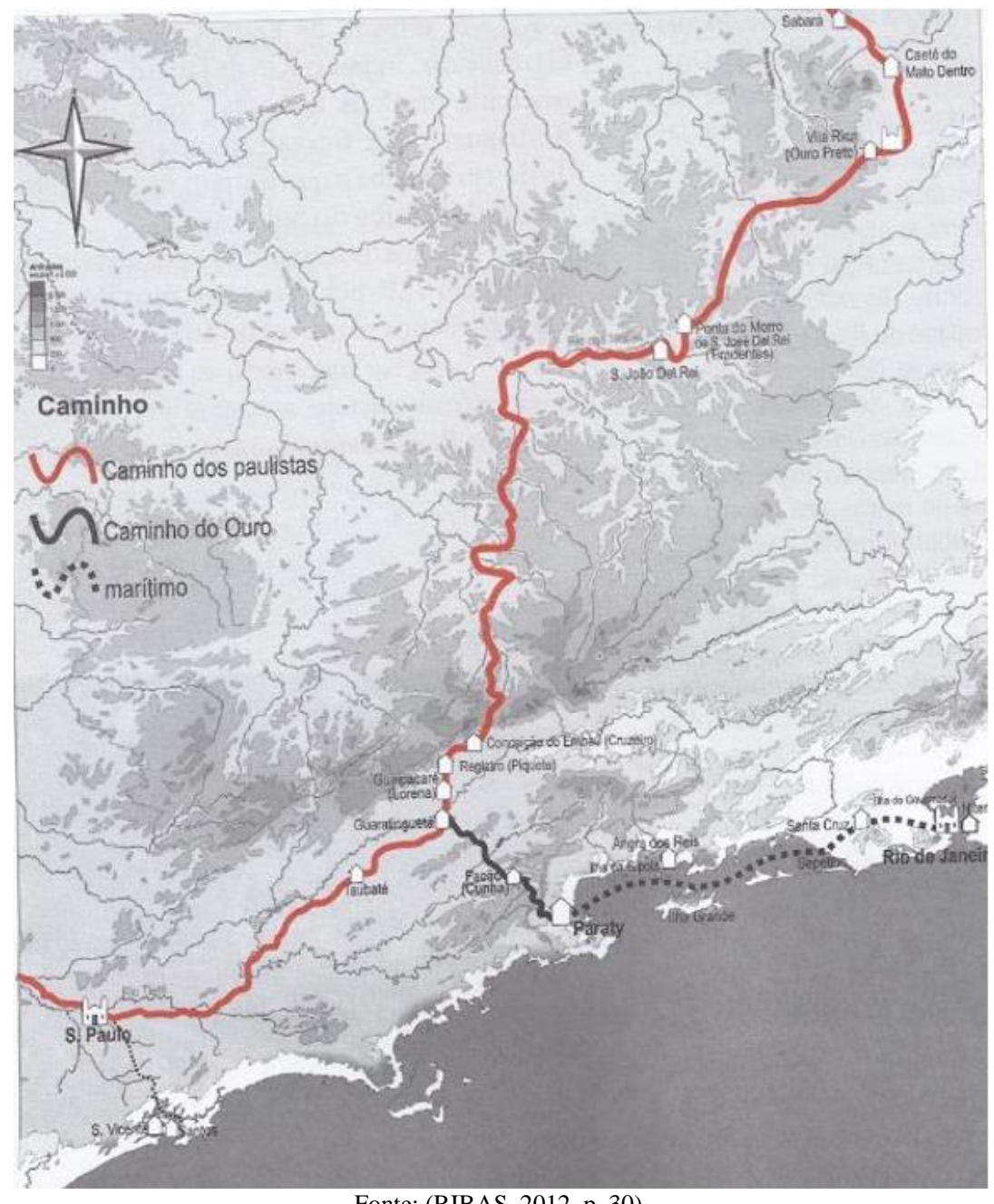

Fonte: (RIBAS, 2012, p. 30).

Tão extenso percurso levou as autoridades a adotarem outra alternativa para chegar-se à região aurífera. Desta maneira, foi estabelecido o Caminho Novo, interligando Minas Gerais ao porto do Rio de Janeiro, conforme observado no Mapa 02. 


\section{Mapa 2 - O Caminho Novo}

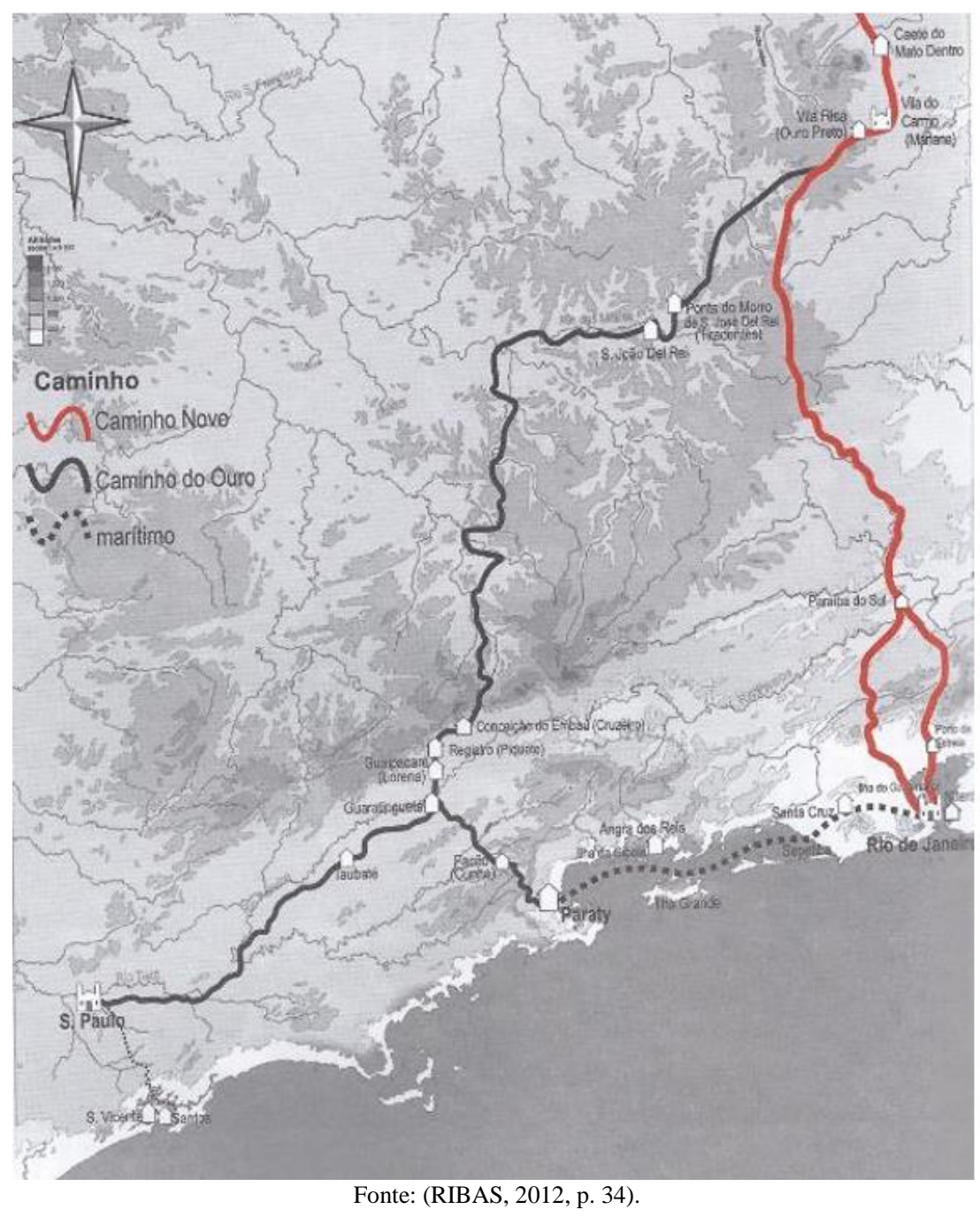

Tal alteração de rota auxiliou imensuravelmente a logística, uma vez que as viagens passaram a durar aproximadamente doze dias. Sendo assim, a viagem foi reduzida de dois meses para pouco menos de meio mês. Este feito contribuiu, inclusive, para um maior dinamismo comercial, além de instituir o Rio de Janeiro como principal porto do Brasil:

Quanto ao Caminho Velho e o Novo para as minas, o grande interesse comercial sem dúvida, prendeu-se ao segundo pois do Rio de Janeiro demandava o interior através de percurso menor e de mais fácil acesso às Gerais. Isto, não só por estas facilidades, mas porque com a sua abertura, nos primórdios dos Setecentos, o Rio de Janeiro tornou-se o principal porto por onde praticamente "respiravam" comercialmente as Gerais. (ELLIS, 1958, p. 464)

O Caminho Velho e o Caminho Novo se encontravam em Ouro Preto. A partir deste ponto um novo trajeto foi estabelecido, o Caminho dos Diamantes, que seguia até o Arraial do Tejuco, atual cidade de Diamantina, conforme demostrado na Imagem 01. 


\section{Imagem 1 - Marco Estrada Real localizado em São Goncalo do Rio das Pedras/MG}

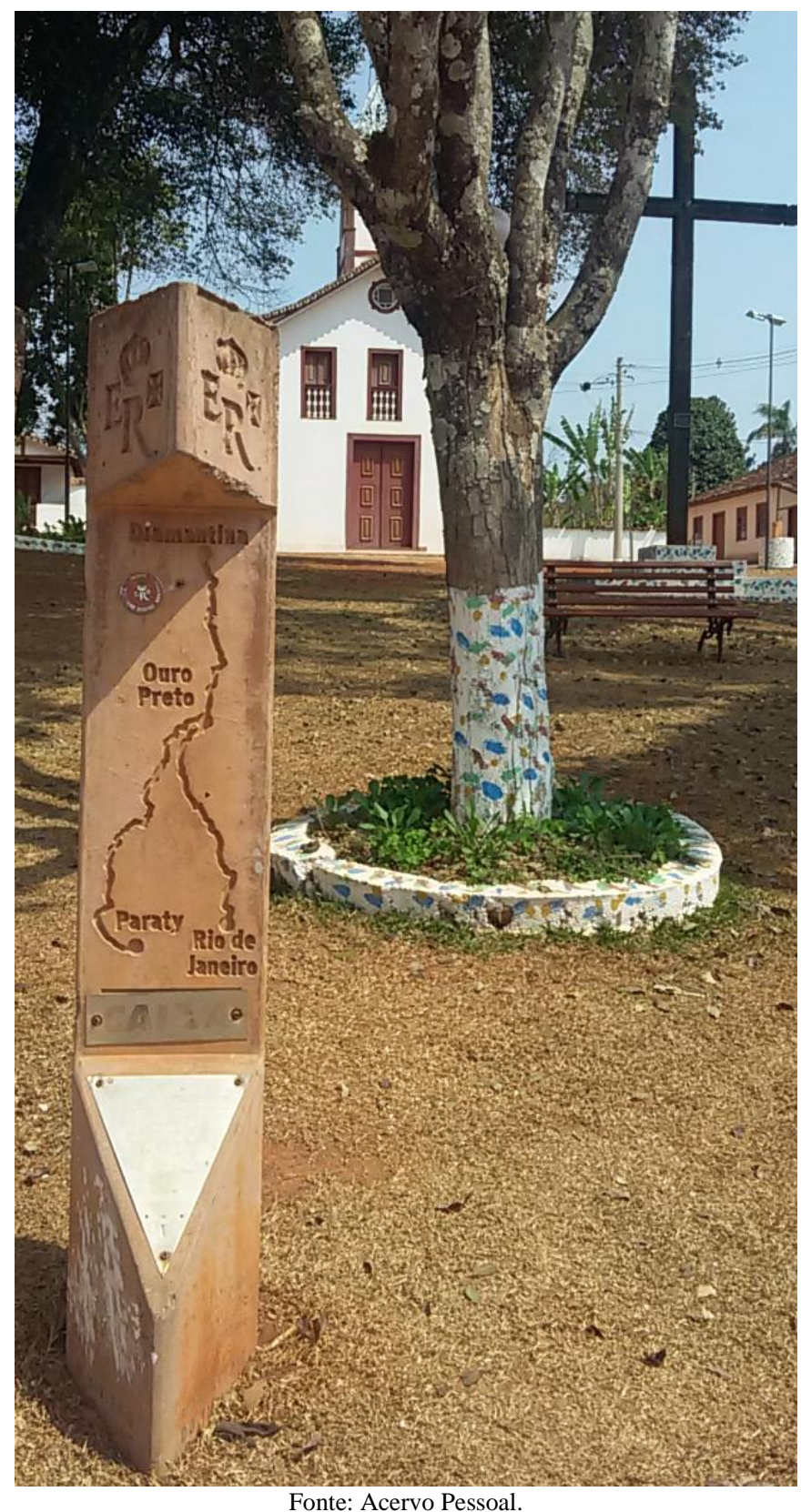

Deste modo, como consequência desta nova dinâmica comercial, fortalecimento do mercado interno, interligação entre as regiões da Colônia, desenvolvimento do sistema de transportes e abertura de estradas que levavam as mercadorias a Minas Gerais e escoavam o ouro até o porto, criou-se uma inédita sistemática tributária em solos brasileiros. Além da arrecadação fiscal por meio dos dízimos e os impostos incidentes sobre a produção, passamos a observar neste período a incidência tributária sobre as pessoas e animais que passavam pelas Barreiras e Passagens instaladas no trajeto das estradas e margens dos 
rios. Paralelamente, toda a mercadoria entrante nas regiões auríferas ocasionava um novo fato gerador tributário, sobre elas havia o recolhimento fiscal sob a nomenclatura entradas. $\mathrm{O}$ pagamento deste imposto era efetuado nos postos de arrecadação denominados Registros. Temos a partir deste momento o início da tributação sobre a circulação interna de mercadorias, somado ao já conhecido, e amplamente debatido, dízimo.

Este feito pouco agradou a população que residia nas Gerais e os comerciantes que negociavam com esta localidade. Ao mesmo tempo, também incomodou os afortunados descobridores de ouro, pois estes deveriam fazer o recolhimento do quinto. A Estrada Real possuía o objetivo de impedir as práticas de sonegação fiscal, no entanto, como bem colocado por observadores da época, "quantos mais forem os caminhos mais descaminhos haverá". (RIBAS, 2003, p. 29) Adiante discutiremos a estrutura fiscal instalada na região aurífera e nos caminhos que a ela conduziam, bem como seus tributos.

\section{A dinâmica tributária na mineração}

Assim como nas considerações sobre a tributação existente no Brasil nos séculos XVI e XVII, inicialmente faremos o levantamento da estrutura tributária administrativa instalada na região aurífera. Posteriormente trataremos dos tributos em si.

Como já observado, nosso foco consiste em analisar a dinâmica tributária oriunda da circulação de pessoas, animais e mercadorias. Sem dúvida o quinto, e seus desdobramentos, em muito impactou a população local que dele sofreu. Não estamos negligenciando este capítulo de nosso passado e muito menos dirimindo suas consequências. No entanto, a proposta desta narrativa consiste em identificarmos as raízes da tributação sobre o consumo brasileiro presente no século XXI. Entendemos que a reflexão sobre as entradas, e sua estrutura arrecadatória, representa um precioso "mapa da mina" a nos conduzir nesta jornada.

Abundante era o ouro, muitos eram seus desbravadores e incontáveis eram os descaminhos e tentativas de sonegação de impostos. Diante deste contexto, passou a ser observada uma maior preocupação da Coroa no tocante ao recolhimento tributário e fiscalização da região aurífera. Se o ouro era extraído, $20 \%$ desta produção era de direito da Coroa. Além disso, contrariando a sistemática arrecadatória até então observada, o 
recolhimento do quinto não fora colocado em hasta pública. A Portugal muito interessava a atuação direta sobre este imposto e todo um aparato fiscalizador foi construído objetivando evitar a evasão tributária e pacificar os conflitos existentes na região:

Para executar o Regimento, cobrar o quinto, superintender todo o serviço da mineração e resolver os pleitos entre os mineradores, bem como destes com terceiros, em questões atinentes à mineração, criou-se um organismo administrativo especial: a Intendência de Minas. Em cada capitania em que houve extração de ouro organizou-se uma Intendência que nas suas atribuições independia completamente das demais autoridades coloniais: só prestava contas e obediência ao governo da metrópole. Compunha-se a Intendência de um superintendente, conhecido vulgarmente como intendente, a quem cabia a direção geral do serviço, e de um guarda-mor, que é quem fazia a repartição das datas e fiscalizava, nas minas, a observância do Regimento. (PRADO JR., 2011, p. 184)

Deste modo, criou-se um órgão autônomo das demais estruturas administrativas existentes na Colônia. A Intendência de Minas respondia diretamente à Metrópole e somente dela recebia ordens. $\mathrm{O}$ ouro incitou na Coroa lusa o entendimento que era necessária uma estrutura administrativa fiscal, presente no Brasil, diretamente ligada a ela. No entanto, pouco ou nada se fez no tocante aos demais assuntos administrativos que não o recolhimento do quinto. Em essência, ao Reino interessava tão somente o direito que lhe cabia dos $20 \%$ sobre o ouro e coibir os descaminhos:

As Intendências não exerceram efetivamente e de forma normal senão a função de cobrar o quinto e fiscalizar os descaminhos do ouro. Para isso estavam bem aparelhadas, e sempre agiram com o máximo rigor. Mas é só: no mais, pouco ou nada faziam. (PRADO JR., 2011, p. 185)

Para se fazer atuante, a Intendência de Minas criou a Casa de Fundição, esta era incumbida em efetuar o recolhimento do quinto. Sobre a maneira como este órgão procedia, observa-se:

Subordinava-se à Intendência a Casa de Fundição, onde se recolhia obrigatoriamente todo o ouro extraído, e onde, depois de fundido, ensaiado, quintado (isto é, deduzido do quinto da Coroa) e reduzido a barras cunhadas, era devolvido ao portador acompanhado de um certificado de origem que provava o cumprimento das formalidades legais e com que deviam circular as barras. Só então podia o ouro correr livremente e ser expedido para fora da capitania. (PRADO JR., 2011, p. 184)

Com o intuito de entendermos a estrutura erigida, bem como a dinâmica fiscalizatória que a Intendência exercia sobre a Casa de Fundição, analisemos a proximidade geográfica entre os edifícios que, no período em estudo, abrigavam estes órgãos administrativos. Na Imagem 02 é possível observar, no antigo Arraial do Tejuco, o prédio da Intendência à 
esquerda e a Casa de Fundição à direita (onde atualmente funciona uma agência bancária).

\section{Imagem 2 - Edifícios da Antiga Intendência e Casa de Fundição, Diamantina/MG}

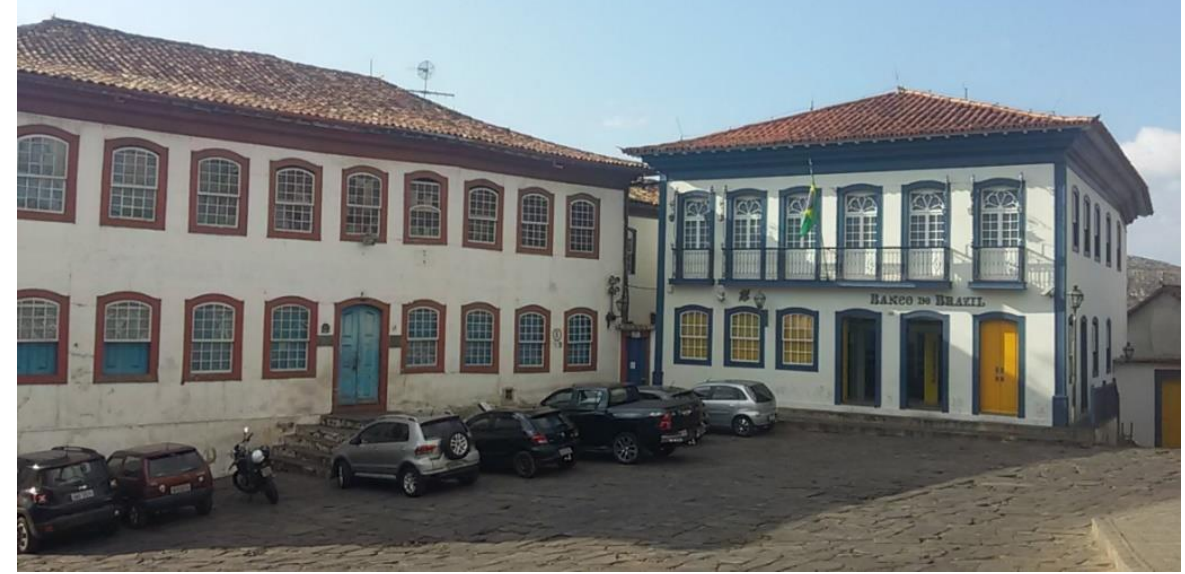

Fonte: Acervo Pessoal

Retornando à nossa narrativa tributária, o quinto não foi o único imposto presente na região das minas. Conforme exposto nas considerações econômicas acerca da mineração, a nascente realidade proporcionou uma nova dinâmica para a Colônia ao interligar as diversas regiões do país e promover a circulação interna de pessoas e mercadorias, destinadas principalmente às regiões auríferas.

Deste modo, Portugal enxergou nesta conjuntura a oportunidade em criar mais um mecanismo tributário. Sem abrir mão da tributação sobre a produção, representada principalmente pelo dízimo e pelo quinto, a Coroa passou também a cobrar impostos sobre as pessoas, animais e mercadorias que passassem por determinados postos de recolhimentos tributários, as Barreiras, Passagens e Registros. Os impostos incidentes sobre as mercadorias e coletados nos Registros eram denominados entradas.

Acerca da atuação dos Registros, estes se caracterizavam por serem "portos secos" instalados nos caminhos que levavam às zonas de exploração do ouro e pedras preciosas, cabendo a eles significativa importância nesta nova dinâmica tributária:

Os "Registros", estabelecimentos fiscais, verdadeiras alfândegas que, postadas à beira das vias terrestres ou fluviais, para os territórios auríferos do país, tinham por fim arrecadar os direitos de entradas naquelas regiões, direitos pertencentes à coroa, ora administrados pela Fazenda Real, ora 
arrematados por contratadores. Tiveram estes "Registros", sem dúvida, importante função na história tributária do Brasil. (ELLIS, 1958, p. 436)

Desta maneira, foram criadas as estruturas necessárias para o recolhimento tributário daqueles que se aventurassem a desbravar as regiões auríferas e efetuar transações comerciais com este território. Temos todo um aparato administrativo criado com o intuito de realizar a maior arrecadação possível. A Estrada Real transformou-se em um verdadeiro trajeto de recolhimento tributário. Nos muitos caminhos que conduziam às minas eram muitas as Barreiras e Registros. Ademais, estes postos de arrecadação eram meticulosamente pensados e normalmente instalados em pontos estratégicos, pois tinham como função potencializar a arrecadação e inibir os descaminhos:

Eram estes postos fiscais estabelecidos nos limites dos distritos mineradores, nos principais e mais frequentados pontos das rotas que buscavam aquelas regiões. Constantemente guardados por destacamentos militares, controlavam a saída do ouro das minas, procuravam evitar os descaminhos e os contrabandos, fiscalizavam e cobravam taxas sobre pessoas, animais e gêneros. Não eram fixos; podiam ser transferidos de uma região para outra, para o melhor controle das passagens. (ELLIS, 1958, p. 436)

Abaixo notamos um dos pontos estratégicos nos quais os Registros eram instalados. De acordo com a história oral da localidade de Diamantina, o edifício à esquerda da Imagem 03 funcionou, no período da mineração e extração de diamantes, como posto de recolhimento fiscal. É possível constatar que este Registro foi construído no caminho que conduz a uma ponte, procurando, desta maneira, evitar o contrabando, a sonegação e o descaminho. Ademais, estamos nos referindo a uma região limítrofe entre São Gonçalo do Rio das Pedras, atual distrito do Município de Serro, e a cidade de Diamantina. 


\section{Imagem 3 - Antigo Registro situado na região limítrofe entre Serro/MG e Diamantina/MG}

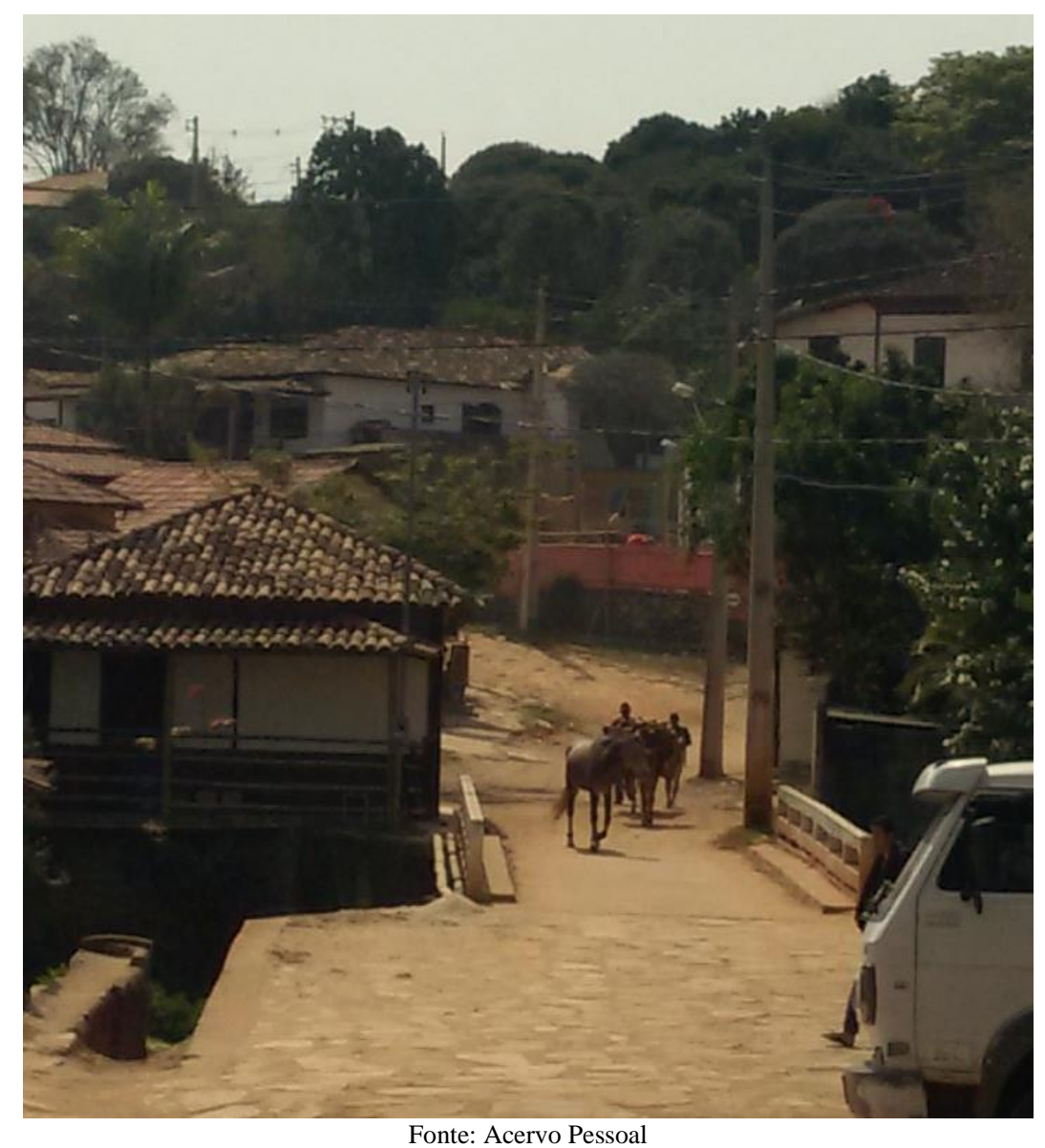

Sendo assim, temos um importante mecanismo angariador de impostos instaurado no Brasil colonial, propiciando à Real Fazenda uma inovação no tocante ao aparato tributário até então vigente.

Sobre a maneira como era efetuada a administração dos contratos sobre os Registros e, consequentemente, dos direitos de entradas, o que se constatou foi divergente do observado sobre o recolhimento do quinto. Neste caso, a Coroa optou por dar continuidade ao modelo instalado no período açucareiro, arrematando os contratos de direito de arrecadação para quem oferecesse o maior lance. Também neste caso, os contratos permaneciam sob administração da Real Fazenda somente quando não havia interessados em arrematar tais direitos.

Por meio da Imagem 04 é possível observar o prédio que abrigou a Casa dos Contratos no século XVIII, no antigo Arraial do Tejuco. 


\section{Imagem 4 - Antiga Casa dos Contratos, Diamantina/MG}

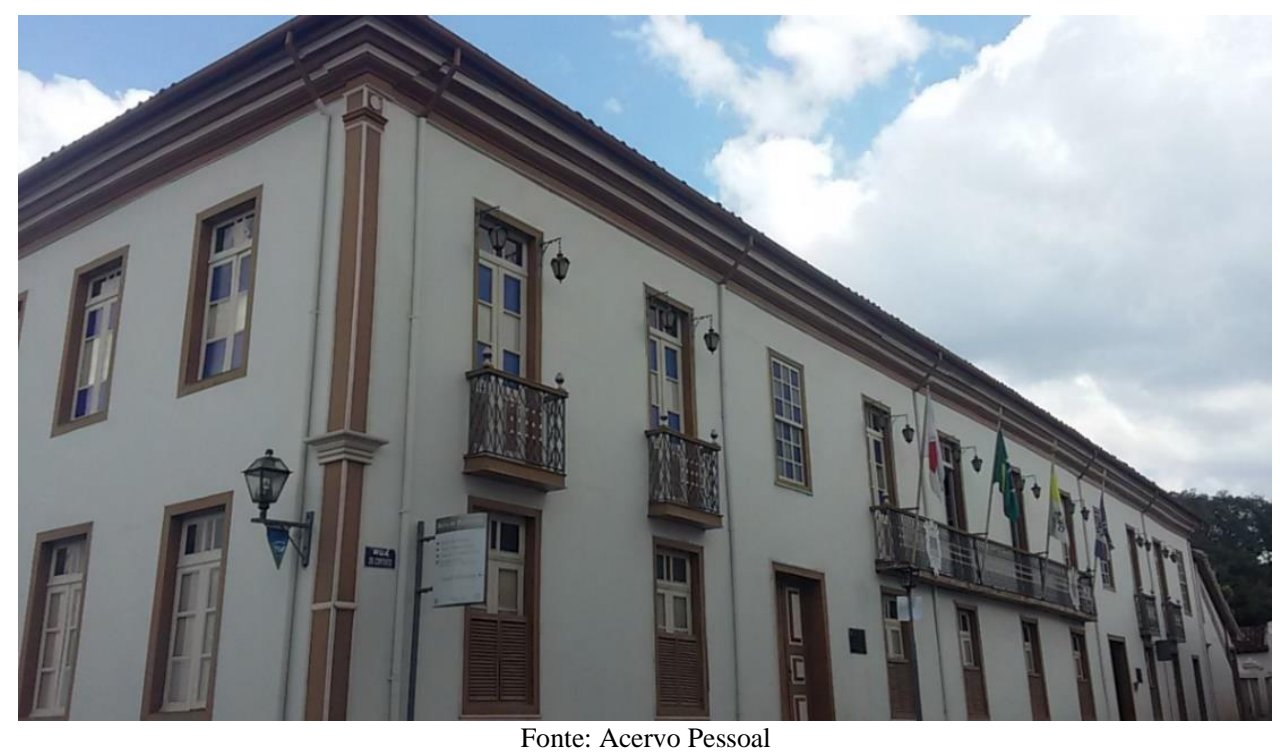

Ademais, temos que considerar as influências e impactos que a arrematação dos contratos por particulares exercia no cotidiano da localidade e da população que ali estava instalada. No caso dos contratos dos dízimos, os coletores de impostos se locomoviam até a unidade produtora. Contudo, o recolhimento tributário das entradas ocorria quando da passagem das mercadorias pelos postos instalados nos caminhos. Desta maneira, priorizando uma maior arrecadação dos direitos de entradas, medidas que poderiam vir a promover uma melhoria nos caminhos e que trariam impactos positivos na vida da população eram evitadas, pois gerariam desdobramentos negativos para o recolhimento de impostos. Quando tal contexto se apresentava, os interesses locais eram colocados em segundo plano:

Outras pretensões de interesse econômico local também surgem e não poucas saíam escusadas. Como aconteceu a proposta apresentada pelas vilas de São João d'El-Rei e de São José d'El-Rei de às suas custas construírem uma ponte sobre o Rio das Mortes. A realeza não concedeu, porque isso implicava a perda da sua receita das passagens das canoas. Mais complicado ainda: como essas receitas estavam entregues a contratadores que tinham que pagar o valor da arrematação à fazenda real, era impossível na vigência de um contrato mudar esse aspecto da vida da terra, mesmo que em benefício dos moradores. Porque os contratos se queriam estáveis. (MAGALHÃES, 2011, pp. 152-153)

Deste modo, procuramos trazer luz ao novo contexto administrativo tributário que passa a se consolidar nos Setecentos. A descoberta do ouro promoveu no Reino uma atuação mais próxima acerca dos assuntos fiscais, ocorrendo pela primeira vez o interesse em 
fazer o recolhimento tributário sem intermédio de particulares, mesmo que tal ação se concentrasse tão somente na arrecadação do quinto.

Além disso, com relação às Passagens, Barreiras, Registros e os direitos de entradas, todo um aparato necessitou ser construído para que se realizasse a tributação sobre a circulação interna de pessoas, animais e mercadorias. Não podemos negar a importância e representatividade desta dinâmica tributária nascente na Colônia neste período.

Esta nova sistemática impactou significativamente não somente os recolhimentos tributários em si, mas também o cotidiano e o consumo dos habitantes das zonas auríferas. Se, por meio dos dízimos, o ônus tributário era diretamente percebido pela diminuição da quantidade da produção na mão dos produtores, por intermédio das entradas os custos com os impostos eram diretamente sentidos pelos consumidores por meio dos elevados preços das mercadorias ${ }^{25}$. Adiante faremos a análise da incidência tributária sobre a circulação de pessoas, animais e mercadorias destinadas às minas, bem como a influência tributária sobre os valores dos bens comercializados nesta região.

\section{Tributos - Entrou, passou, pagou}

Analisar a realidade econômica e fiscal dos Setecentos nos remete aos estudos acerca da conjuntura vivenciada nas regiões auríferas. De acordo com o relatado nas linhas anteriores, a Colônia passou a experimentar um novo contexto e uma metamorfose em seu cotidiano e em suas trocas comerciais. Esta nascente característica em muito influenciou as relações entre o Reino e sua posse americana, deslocando o principal polo econômico e, consequentemente, gerador de recursos fiscais do Nordeste para o Sudeste:

A mineração provocou a irrupção dos mercados interiores, alterou o eixo de gravidade econômica antes localizado entre Bahia e Recife, e guindou o Rio de Janeiro à condição de principal praça mercantil da colônia. (...), em termos fiscais, foi responsável pela quase totalidade das remessas líquidas para a Coroa ao longo do século XVIII - entre 1736 e 1756, por exemplo, a Coroa portuguesa recebeu em remessas líquidas do Brasil 17.013:000\$000 réis, dos quais 14.913:326\$985 réis (isto é, 87,65\%) só de Minas Gerais. (CARRARA, 2009, p. 10)

\footnotetext{
${ }^{25}$ No caso das Minas Gerais os impactos tributários gerados no preço das mercadorias eram exorbitantes. Neste caso, ao contrário do comumente observado nos dias atuais, a mão do fisco era pesadamente notada.
} 
Tão importante quanto o quinto, as entradas constituíram preciosa fonte de recursos fiscais ao Erário e aos agentes particulares. Inúmeros são os estudos sobre os Contratadores atuantes no período, alguns conquistaram considerável riqueza, inclusive estruturando uma teia de negócios no "comércio tributário"26. As entradas estavam para a região aurífera assim como os dízimos estavam para a região açucareira.

Tal entendimento deste contexto advém da dinâmica instaurada nas minas. Efetuar comércio com esta localidade necessariamente implicava em considerar o custo tributário que recaía sobre todas as pessoas e mercadorias entrantes. Deste modo, se nas regiões produtoras e fornecedoras havia o imposto sobre a produção, nas localidades receptoras e consumidoras teria que se pagar as entradas:

Todos os gêneros comerciados naquelas regiões, na passagem dos mercados fornecedores para os consumidores, eram onerados pelos tributos "das entradas" impostos pela Real Fazenda aos traficantes e cobrados nos "Registros", postos de cobrança estabelecidos nas vias de penetração para as zonas auríferas. (ELLIS, 1958, p. 430)

Todavia, por mais que houvesse tal ônus tributário acrescido ao preço das mercadorias, não podemos afirmar que seu peso foi sentido com a mesma intensidade durante todo o período em estudo. Inicialmente optou-se por uma fiscalização menos rígida sobre as entradas a fim de propiciar a migração para as minas. Um maior contingente populacional implicaria em possibilidades de maiores extrações de ouro:

Nos primeiros tempos da mineração, nos sertões das Gerais, o comércio de importação consistia exclusivamente de gêneros alimentícios para o sustento dos povoadores e de instrumentos para o trabalho nas lavras, abertura de caminhos e desbastamento de matas. Gêneros "secos" eram os não comestíveis. Pagavam 1 \$125 réis por arroba ao entrarem nas minas. Gêneros "molhados" designavam os destinados à alimentação. Sobre eles pesava a taxa de 750 réis por carga, cujo volume correspondia de 2 até 3 arrobas. Foi esse um período em que a irregularidade e a indisciplina imperavam na cobrança e no pagamento dos direitos das entradas. É que prevalecia, por parte da administração da Colônia, o interesse pelo incentivo ao povoamento e à exploração do ouro. (ELLIS, 1958, p. 446)

No entanto, a mesma conduta permissiva quanto a sonegação e falta de diligência na cobrança dos impostos incidentes sobre a circulação de pessoas, animais e mercadorias destinadas às minas não se manteve vigente por longo período. Para fazermos tal análise, tomemos como exemplo o comportamento ascendente do valor dos contratos das

\footnotetext{
${ }^{26}$ Tomemos como exemplo a Tese de Doutorado de PEREIRA, Alexandra Maria. Das Minas à Corte, de Caixeiro a Contratador: Jorge Pinto de Azeredo. Atividade mercantil e negócios na primeira metade do século XVIII. São Paulo: FFLCH/USP, 2013.
} 
entradas. Quanto maior era a possibilidade de arrecadação com os contratos, maiores eram também as possibilidades de a Coroa elevar os preços de arrematação.

Mediante estudo comparativo entre os valores arrecadados pela Real Fazenda com o contrato do dízimo e o contrato das entradas, no período de 1722 a 1765, podemos constatar que os direitos de arrematação dos dízimos possuem comportamento oscilante, com inúmeras altas e baixas. No entanto, o mesmo movimento não é observado sobre a arrecadação provinda do contrato das entradas, que se caracterizam por um comportamento ascendente, conforme ilustrado no Quadro 24:

\section{Quadro 24 - Conta Corrente dos Contratos dos Dízimos e das Entradas, $\underline{(1722-1765)}$}

\begin{tabular}{|c|c|c|c|c|c|}
\hline & Dízimos & Entradas & & Dízimos & Entradas \\
\hline & Valor Pago & Valor Pago & & Valor Pago & Valor Pago \\
\hline 1722 & $40: 082 \$ 117,50$ & $93: 880 \$ 240,00$ & 1744 & $99: 089 \$ 147,00$ & $174: 550 \$ 958,00$ \\
\hline 1723 & $49: 111 \$ 646,50$ & $93: 880 \$ 240,00$ & 1745 & $92: 038 \$ 000,00$ & $178: 679 \$ 838,16$ \\
\hline 1724 & $49: 111 \$ 646,50$ & $94: 744 \$ 801,00$ & 1746 & $92: 038 \$ 000,00$ & $191: 066 \$ 479,00$ \\
\hline 1725 & $61: 423 \$ 980,33$ & $97: 338 \$ 480,00$ & 1747 & $92: 038 \$ 000,00$ & $191: 066 \$ 479,00$ \\
\hline 1726 & $78: 661 \$ 245,83$ & $97: 338 \$ 480,00$ & 1748 & $92: 038 \$ 000,00$ & $191: 058 \$ 391,50$ \\
\hline 1727 & $78: 661 \$ 245,83$ & $97: 475 \$ 136,66$ & 1749 & $92: 038 \$ 000,00$ & $191: 034 \$ 128,50$ \\
\hline 1728 & $68: 018 \$ 625,33$ & $86: 990 \$ 038,66$ & 1750 & $92: 068 \$ 700,00$ & $191: 034 \$ 128,50$ \\
\hline 1729 & $53: 118 \$ 957,66$ & $86: 990 \$ 038,66$ & 1751 & $92: 111 \$ 680,33$ & $192: 585 \$ 586,00$ \\
\hline 1730 & $53: 118 \$ 957,66$ & $89: 259 \$ 991,00$ & 1752 & $92: 111 \$ 680,33$ & $197: 239 \$ 600,83$ \\
\hline 1731 & $58: 607 \$ 124,00$ & $96: 069 \$ 851,66$ & 1753 & $80: 558 \$ 902,66$ & $197: 239 \$ 600,83$ \\
\hline 1732 & $66: 290 \$ 555,16$ & $96: 069 \$ 851,66$ & 1754 & $64: 385 \$ 013,33$ & $198: 921 \$ 544,00$ \\
\hline 1733 & $66: 290 \$ 555,16$ & $104: 944 \$ 060,16$ & 1755 & $64: 385 \$ 013,33$ & $203: 967 \$ 333,50$ \\
\hline 1734 & $82: 357 \$ 947,66$ & $131: 566 \$ 612,00$ & 1756 & $67: 281 \$ 541,00$ & $203: 967 \$ 333,33$ \\
\hline 1735 & $104: 825 \$ 298,66$ & $131: 566 \$ 612,00$ & 1757 & $71: 336 \$ 680,00$ & $181: 535 \$ 379,83$ \\
\hline 1736 & $104: 825 \$ 298,66$ & $138: 274 \$ 579,66$ & 1758 & $71: 336 \$ 680,00$ & $114: 239 \$ 519,83$ \\
\hline 1737 & $97: 708 \$ 529,66$ & $158: 398 \$ 546,66$ & 1759 & $73: 405 \$ 439,00$ & $195: 739 \$ 000,00$ \\
\hline 1738 & $94: 763 \$ 730,00$ & $158: 398 \$ 546,66$ & 1760 & $76: 301 \$ 680,00$ & $195: 739 \$ 000,00$ \\
\hline 1739 & $104: 642 \$ 798,33$ & $162: 420 \$ 488,66$ & 1761 & $76: 301 \$ 680,00$ & $195: 739 \$ 000,00$ \\
\hline 1740 & $104: 642 \$ 798,33$ & $174: 486 \$ 319,00$ & 1762 & $76: 680 \$ 846,66$ & $195: 881 \$ 000,00$ \\
\hline 1741 & $104: 427 \$ 332,33$ & $174: 486 \$ 319,00$ & 1763 & $77: 211 \$ 680,00$ & $195: 881 \$ 000,00$ \\
\hline 1742 & $104: 125 \$ 680,33$ & $174: 502 \$ 478,83$ & 1764 & $77: 211 \$ 680,00$ & $195: 881 \$ 000,00$ \\
\hline 1743 & $104: 125 \$ 680,33$ & $174: 550 \$ 958,00$ & 1765 & $45: 039 \$ 634,00$ & $203: 438 \$ 420,50$ \\
\hline
\end{tabular}

De acordo com os dados sumarizados acima, podemos constatar que o valor arrecadado com os dízimos em seu ano inicial foi de 40:082\$117,50. Em seu melhor momento, nos anos de 1735-1736, o rendimento para a Real Fazenda foi de 104:852\$298,66. Todavia, no último ano da série, 1765, observamos um numerário muito próximo do ano inicial. Em síntese, por mais que em determinado período o valor do contrato do dízimo tenha dobrado, quando comparado ao valor inicial, tal desempenho não manteve a mesma dinâmica no decorrer das décadas. Contudo, necessitamos fazer uma importante observação quanto a característica do dízimo em solos mineratórios. Estes incidiam, 
preponderantemente, sobre a produção dos produtos que eram consumidos localmente e não sobre os gêneros destinados à exportação, como no caso de Bahia e Pernambuco:

No que respeita aos dízimos do Brasil, deve-se fazer uma distinção fundamental: até o descobrimento do ouro nos anos finais do século XVII, os dízimos correspondiam fundamentalmente à produção dos gêneros agrícolas destinados à exportação (açúcar e tabaco, principalmente). $\mathrm{O}$ arrendamento se concentrava no eixo Bahia - Pernambuco, que representava $80 \%$ da produção exportável brasileira, ao passo que nas áreas mineradoras os gêneros sobre os quais incidia a cobrança eram os destinados ao abastecimento interno: milho, feijão e carnes, especialmente. (CARRARA; SANTIRÓ, 2013, p. 171)

Desta maneira, temos que, finda a prosperidade do período açucareiro, os dízimos passaram a ter uma maior relevância sobre a economia interna, algo que no período anterior não se observava. A tributação sobre a produção a ser consumida nas Gerais representou uma importante base de incidência deste imposto, que ainda figurava entre as maiores fontes de arrecadação, mas não mais a principal.

Retomando as considerações sobre o Quadro 24, quanto ao valor do contrato das entradas, é possível afirmar que sua trajetória foi consolidada de maneira crescente e constante, com exceção para o ano de 1758, aonde se observa uma queda abrupta de praticamente $38 \%$ em relação ao ano anterior. Entretanto, quando analisados seus valores inicial e final, detectamos que o valor pago pelo contrato das entradas mais que dobrou. Além disso, também notamos que no decorrer dos anos este desempenho foi se construindo, de um modo geral, paulatina e constantemente. Sendo assim, averiguamos ser este o principal tributo do período, com exceção do quinto.

Imagem 5 - Rendimento Fiscal da Capitania de Minas Gerais: Quintos, Dízimos e Entradas de Mercadorias, (1700-1820)

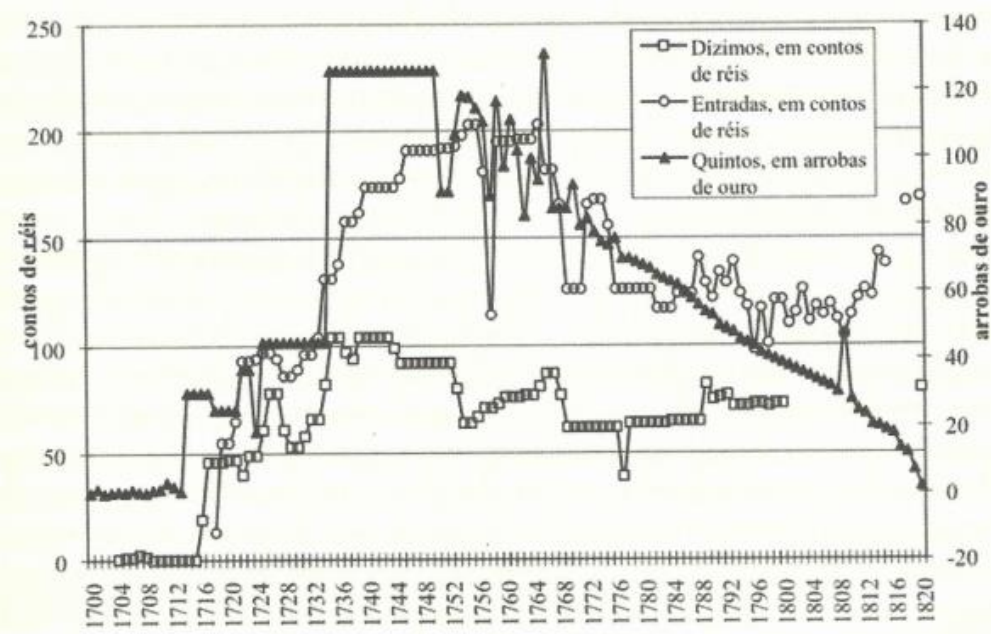

Fonte: (CARRARA, 2009, p. 08). 
Por intermédio da Imagem 05 podemos averiguar a representatividade dos principais tributos do período: quintos, entradas e dízimos, sucessivamente. Por mais que os valores demonstrados representem, "em princípio, e à exceção dos quintos de 1751 em diante, uma expectativa de receita, e não o montante efetivamente ingressado nos cofres da Fazenda Real” (CARRARA, 2009, pp. 08-09), não podemos negligenciar o fato de as entradas em muito contribuírem para a dinâmica fiscal da Capitania de Minas Gerais. Inclusive, uma análise mais cuidadosa demonstra que a partir de meados da década de 1750 as entradas passaram a ter uma representatividade similar aos quintos. O posto de maior fonte arrecadatória entre estes dois impostos alterna-se durante quase três décadas. Contudo, a partir de 1788 as entradas consolidaram seu lugar de pioneiras para não mais serem superadas, apresentando o quinto um comportamento decadente e contínuo até o final do período.

Deste modo, passemos à próxima etapa de nosso estudo, que consiste em procurar relacionar o efeito que a carga tributária ocasionou nos preços dos produtos comercializados em Minas Gerais e arredores. Entendemos que a compreensão desta realidade representa uma importante oportunidade para a reflexão sobre a estrutura fiscal instaurada neste momento da Colônia. Ademais, esta análise em muito contribui para a construção das raízes da atual tributação sobre o consumo. Nas palavras de Ellis:

No panorama da História da mineração no Brasil do século XVIII, o regime tributário das "entradas" imposto às mercadorias, animais e escravos destinados às Gerais, a Mato Grosso, Goiás e a algumas zonas auríferas de menor importância, assume relevante papel no que concerne ao abastecimento daquelas regiões. Isto, porque se relaciona intimamente à História dos preços na época, dos transportes, dos caminhos, bem como à História administrativa e tributária do Brasil Colonial. (ELLIS, 1958, p. 462)

Isto posto, refletir sobre a realidade tributária e sobre o comportamento dos preços, no período e na região aurífera, necessariamente nos conduz ao questionamento sobre as entradas. O Quadro 24 e a Imagem 05 nos apresentam, em números, a importância que este imposto foi adquirindo no decorrer do século XVIII. Consequentemente, o impacto desta dinâmica arrecadatória se fazia sentir nos preços dos produtos que adentravam a região. Diversos são os relatos sobre os preços abusivos praticados nas localidades mineratórias, preços esses em muito influenciados pelos recolhimentos tributários provenientes das entradas e pelos custos de transporte: 
Outro inconveniente das entradas para as minas consistia no próprio regime das taxas que oneravam os gêneros para lá destinados. Por exemplo, em Minas Gerais, um alqueire de sal - produto tão necessário àquela região, sem o qual os habitantes e os animais não podiam passar - que custava no Rio de Janeiro 720 rs. o alqueire - pagava para entrar nas Gerais a taxa de 750 rs.! Essa taxa, mais as "despesas de avarias" e dos problemas de transporte a grandes distâncias, além de outros gastos, oneravam tanto o sal, que seu preço naquelas minas passava a ser excessivo, $3 \$ 600$ rs. o alqueire. (ELLIS, 1958, p. 460)

Portanto, mercadorias de necessidade básica e extremamente necessárias para a sobrevivência da população, como o sal, eram comercializadas nas Gerais a preços inimagináveis em outras regiões da Colônia. Neste caso em específico, estamos tratando de uma diferença na ordem de $380 \%$. Ademais, chamamos a atenção para o fato de a taxa de entrada por si só já ser superior ao valor do sal comercializado na praça fluminense. Mas a nossa análise não se restringe ao sal, tomemos também como exemplo o ferro, material de fundamental importância para a exploração do ouro:

Destarte, valia no Rio de Janeiro um quintal de ferro manufaturado em instrumentos de trabalho, entre $4 \$ 800$ e $6 \$ 000$ rs.; pagando de direitos de entrada em Minas Gerais $4 \$ 500$ rs., ou 75\% sobre o seu valor, sofrendo o inevitável ônus resultante do transporte e outras despesas mais, esse quintal de ferro era vendido naquela Capitania, por preço de 14\$000 rs. (ELLIS, 1958, p. 460)

Em suma, o instrumento essencialmente utilizado para a principal atividade econômica da região era adquirido por, praticamente, o triplo do preço quando comparado ao valor negociado no Rio de Janeiro.

Diante desta realidade, cabe o questionamento acerca do impacto que tal dinâmica de custos trazia aos habitantes. A realidade que se impunha sobre a obtenção de bens tão essenciais estaria respeitando a curva de utilidade destes consumidores? Mesmo diante de tamanha riqueza, provinda da descoberta do ouro, suas necessidades básicas estariam sendo satisfeitas? Poderíamos afirmar que a carga tributária era distribuída levando em consideração a essencialidade das mercadorias a serem adquiridas, ou novamente no cenário nacional era reinante a regressividade contributiva?

Aquelas taxas lançadas sobre os gêneros de primeira necessidade reduziam o seu consumo, tornando-o muitas vezes proibitivo. Isto, entretanto, não sucedia com os panos e artigos de luxo, "fazenda seca", de consumo mais restrito, cujos preços ultrapassavam de muito o ônus imposto pelas taxas cobradas por peso, na entrada das minas. Assim, um quintal daqueles gêneros de comércio, valendo 100 moedas pagava $4 \$ 500$ para entrar nas minas, isto é, menos de $1 \%$ sobre o seu valor. Valendo 200 moedas, pagava os mesmos $4 \$ 500$, ou menos de $1 / 2 \%$. Valendo ainda mais e pagando os 
$4 \$ 500$, a taxa de entrada, proporcionalmente se reduzia a um valor tão ínfimo, que relativamente equivalia a uma entrada quase sem ônus. (ELLIS, 1958, p. 461)

Deste modo, procuramos esclarecer o cotidiano fiscal e o peso tributário exercido sobre a população que se locomoveu para as Gerais em busca de melhores dias e esperanças de um farto e próspero futuro. Cegos pelo reluzente brilho do ouro, aventuravam-se nesta jornada desafiadora e ilusoriamente criam ser esta a oportunidade de suas vidas. Sim, de fato houve aqueles que se enriqueceram, contudo, muitos também foram aqueles que morreram de fome por falta de alimentos ou pela ausência de ouro suficiente para que a troca comercial se realizasse. O brilho do ouro escondia a sombra da fome, e ofuscava os custos tributários que não eram contabilizados nas mentes daqueles que optavam por seguir em direção às Gerais. A circulação de mercadorias destinadas à região aurífera era onerosa, inúmeros eram os Registros e consideráveis eram as taxas das entradas.

Além da expectativa de enriquecimento, inerente a estes desbravadores, teria de haver também a disposição em arcar com os custos fiscais instalados a cada nova passagem para as minas, custos estes incidentes sobre tudo e todos que adentrassem as fronteiras do "Eldorado".

Ademais, somados aos Registros, outros custos fiscais, além dos já mencionados, oneravam as mercadorias destinadas às Gerais, os impostos alfandegários. "As Gerais começaram a importar gêneros de todas as espécies e qualidades, dando origem a importante comércio estabelecido com todos os pontos do Brasil, principalmente com o Rio de Janeiro". (ELLIS, 1958, p. 446) Deste modo, não poderíamos concluir o estudo sobre Minas Gerais sem tratar desta questão, pois a nova dinâmica econômica vivenciada em muito impactou o Rio de Janeiro e sua Alfândega.

\section{A Alfândega fluminense}

O estabelecimento do Caminho Novo contribuiu para que o Rio de Janeiro, de tímida e quase inexpressiva Capitania nos séculos iniciais da colonização, se consolidasse como a principal porta de entrada e saída de mercadorias do Brasil. A importância econômica que o território carioca e sua Alfândega adquiriu promoveu, inclusive, a transferência da capital da Colônia de Salvador para o Rio de Janeiro, no ano de 1763. 
O porto fluminense se transformou na mais importante Alfândega brasileira e a dízima, imposto incidente sobre as mercadorias importadas e exportadas, mais uma considerável fonte de renda a contribuir para as receitas da Real Fazenda. Sobre as características da dízima, temos:

A dízima é um imposto cobrado sobre $1 / 10$ do valor das mercadorias exportadas e importadas que ingressassem no porto do Rio de Janeiro. Esse imposto reflete a pujança de uma economia, uma vez que revela, grosso modo, a capacidade de realizar transações econômicas com o exterior (medindo a demanda interna e externa). (PESAVENTO, 2012, p. 598)

Por conseguinte, entender a dinâmica adotada pela dízima da Alfândega nos auxilia na reflexão sobre a principal atividade econômica do Rio de Janeiro, a importação e exportação de mercadorias. Por meio de estudos que procuram entender o comportamento fiscal da Capitania do Rio de Janeiro, Carrara esclarece:

(...) no Rio as fontes mais tradicionais de receita, como os dízimos e o estanco da pesca da baleia mantiveram-se nos níveis do século anterior. Foi noutra atividade econômica, o comércio de importação de mercadorias do reino, sobre as quais incidiam impostos como o contrato dos vinhos e a dízima da Alfândega, que a transformação foi sentida de forma intensa. Este último imposto, por exemplo, como ocorreu na Bahia e em Pernambuco, foi guindado à posição de mais importante da fiscalidade fluminense em menos de uma década. (CARRARA, 2009, p. 50)

Desta maneira, ao procurar quantificar esta transformação, o autor apresenta dados que demonstram a trajetória do valor do contrato do dízimo e da dízima da Alfândega no Rio de Janeiro nos anos de 1710 a 1751. O Quadro 25 consolida a coleta dos valores dos contratos destes dois impostos. Enquanto o valor do dízimo se mantém estável no período observado, a dízima da Alfândega mais que quadruplica sua importância.

\section{Quadro 25 - Valor do Contrato dos Dízimos e da Dízima da Alfândega no Rio de} Janeiro, (1710-1751)

\begin{tabular}{|c|c|c|c|}
\cline { 2 - 3 } \multicolumn{1}{c|}{} & Dízimo no RJ & Dízima da Alfândega no RJ \\
\hline $\mathbf{1 7 1 0}$ & $25: 333 \$ 333$ & $\mathbf{1 7 1 2}$ & $53: 200 \$ 000$ \\
\hline $\mathbf{1 7 2 2}$ & $16: 000 \$ 000$ & $\mathbf{1 7 2 1}$ & $66: 600 \$ 000$ \\
\hline $\mathbf{1 7 2 5}$ & $14: 000 \$ 000$ & $\mathbf{1 7 2 4}$ & $97: 200 \$ 000$ \\
\hline $\mathbf{1 7 2 6}$ & $16: 900 \$ 000$ & $\mathbf{1 7 2 9}$ & $122: 100 \$ 000$ \\
\hline $\mathbf{1 7 2 9}$ & $18: 920 \$ 000$ & $\mathbf{1 7 3 2}$ & $107: 600 \$ 000$ \\
\hline $\mathbf{1 7 3 2}$ & $19: 210 \$ 000$ & $\mathbf{1 7 3 4}$ & $160: 000 \$ 000$ \\
\hline $\mathbf{1 7 3 5}$ & $14: 483 \$ 333$ & $\mathbf{1 7 3 8}$ & $194: 805 \$ 000$ \\
\hline $\mathbf{1 7 3 9}$ & $19: 205 \$ 000$ & $\mathbf{1 7 4 2}$ & $208: 400 \$ 000$ \\
\hline $\mathbf{1 7 4 2}$ & $19: 205 \$ 000$ & $\mathbf{1 7 4 5}$ & $209: 600 \$ 000$ \\
\hline $\mathbf{1 7 4 5}$ & $22: 400 \$ 000$ & $\mathbf{1 7 4 8}$ & $202: 400 \$ 000$ \\
\hline $\mathbf{1 7 4 8}$ & $28: 010 \$ 000$ & $\mathbf{1 7 5 1}$ & $202: 400 \$ 000$ \\
\hline $\mathbf{1 7 5 1}$ & $24: 020 \$ 000$ & \multicolumn{2}{|c}{} \\
\hline
\end{tabular}


Procurando complementar os dados apresentados por Carrara, mas agora tratando dos valores de fato arrecadados e traçando uma análise que se estende até meados da primeira década do século XIX, apresentamos as pesquisas de Pesavento. O fato deste autor iniciar sua pesquisa na década de 1740 contribui, inclusive, para o entendimento do comportamento da dízima da Alfândega durante toda a segunda metade do século XVIII, conforme ilustrado na Imagem 06.

\section{Imagem 6 - Evolucão da média de Arrecadacão dos Direitos da Dízima da Alfândega do Rio de Janeiro, (1741-1804)}

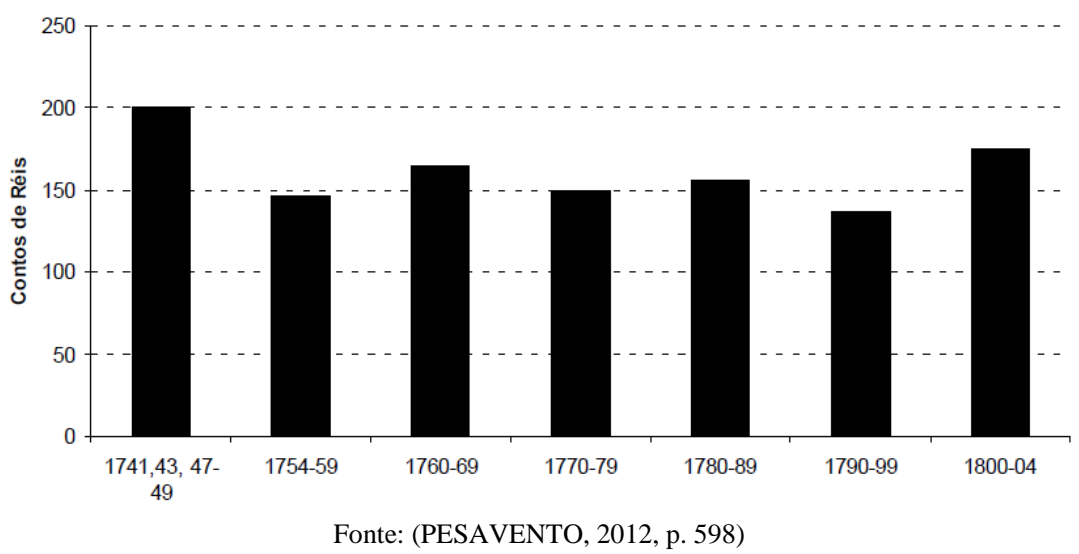

As médias de arrecadação acima sumarizadas demonstram que este imposto rendeu maiores recursos no período inicial da análise, 1741 a 1749. Além disso, ao contrastarmos os dados apresentados no Quadro 25 e na Imagem 06, observamos uma estreita aproximação entre os valores contratados e arrecadados. Nos períodos seguintes, notamos uma queda de aproximadamente 50:000\$000 na arrecadação da dízima, permeando sempre a média dos 150:000\$000 até o penúltimo intervalo de tempo.

Deste modo, procuramos retratar, mesmo que brevemente, a realidade fiscal experimentada pela Capitania do Rio de Janeiro no decorrer dos Setecentos. Abordar a dinâmica dos tributos alfandegários nos permite inferir sobre mais um desdobramento proveniente da extração aurífera no decorrer de todo o século XVIII. A nova realidade econômica e a riqueza gerada pela descoberta do ouro permitiu que a Colônia passasse a importar uma maior quantidade de mercadorias, quando comparado com o período açucareiro. Ademais, este aumento no fluxo de comércio internacional promoveu os impostos alfandegários aos mais importantes mecanismos de recolhimentos fiscais existentes na Colônia, a partir deste período e com exceção do quinto. 
De fato, os tributos alfandegários sempre estiveram presentes em solos brasileiros, no entanto, no decorrer de dois séculos de história não haviam figurado como os principais. Nos séculos XVI e XVII eram os dízimos incidentes sobre a produção, principalmente do açúcar, as principais ferramentas de arrecadação da Coroa. Sim, estamos tratando de produtos destinados à exportação, contudo, o ônus tributário deste período recaiu principalmente sobre a produção.

Com o advento da mineração um novo aspecto passa a figurar, a tributação sobre a circulação interna de mercadorias. A ela soma-se a tributação sobre as mercadorias importadas e exportadas pelo Brasil, sob a dízima, e os dízimos, que não deixaram de existir e ainda representavam um importante mecanismo de recolhimento fiscal.

Sendo assim, seja por meio da tributação sobre a produção, sobre a circulação interna ou sobre as mercadorias importadas e exportadas da Colônia, em essência era o consumo a atividade econômica que gerava recursos fiscais ao Tesouro e aos Rendeiros.

Estes senhores, como já amplamente explanado no decorrer do capítulo, em muito se beneficiaram com a possibilidade de efetuar o recolhimento tributário em terras brasileiras. Construíram respeitosas fortunas e, paralelamente, não mediam esforços para defender seus interesses e cobrar os tributos que lhes eram de direito. Este era o cenário fiscal e administrativo que se apresentava quando da vinda da Corte para o Brasil. No próximo capítulo passaremos a analisar as medidas adotadas neste período e os impactos gerados na estrutura tributária. 


\section{Capítulo 3}

\section{Notas Sobre a Tributação no Brasil Império}

Dando continuidade à nossa narrativa, abordaremos neste capítulo os principais aspectos políticos, econômicos e fiscais apresentados no Período Joanino, Primeiro Reinado, Período Regencial e Segundo Reinado.

Quanto ao recorte temporal, optamos por incluir o Período Joanino nesta discussão por entendermos ser a transferência da Corte para sua Colônia americana o passo inicial que culminou na Independência brasileira no ano de 1822. Tal evento representa um momento no qual a estrutura administrativa e tributária da Colônia passa a ser repensada. Este movimento não pode ser ignorado por oferecer contribuições significativas para o estudo.

Ainda no século XIX, abordaremos o episódio acerca da separação das rendas tributárias em geral e provincial e o início da formação do Pacto Federativo, tal qual entendido atualmente. Conhecer a dinâmica econômica deste período e seu principal tributo será de extrema valia para a construção desta resenha.

Ademais, devemos esclarecer que, ao contrário do observado no capítulo anterior quanto a utilização de fontes primárias para a análise da questão, devido à sua escassa disponibilidade, no decorrer das próximas linhas elas se farão presentes e primordiais.

\section{A Chegada da Corte: Repensando a Estrutura Tributária}

Intensos conflitos, disputas e guerras marcaram o território europeu em fins dos Setecentos e início dos Oitocentos. A contenda entre França e Inglaterra deixou suas sequelas em Portugal e, consequentemente, no Brasil.

Com receio dos exércitos napoleônicos, o então príncipe regente D. João VI e toda a sua Corte atravessou o Atlântico escoltado pela marinha inglesa, sua maior aliada e a quem muito interessava as trocas econômicas que estabelecera com Portugal. 
De certo que a Coroa britânica não estava tomada de sentimentos meramente altruístas e compassivos ao promover o socorro aos lusos. Novamente estavam em pauta vantagens comerciais que seriam advindas deste ato, mas não antecipemos os fatos.

\section{O Período Joanino}

Com a vinda de D. João VI ao Brasil temos o Período Joanino, iniciado em 1808 e findo em 1821, com seu retorno a Portugal. No decorrer destes quase 15 anos alterações foram testemunhadas nos solos brasileiros, alterações estas que também fizeram-se sentir na estrutura tributária brasileira.

A instalação da Corte portuguesa, bem como todo seu aparato, impactou o modus operante da Colônia. Transformações passaram a vigorar nas terras que até então serviram tão somente para a exploração. Temos, nas palavras de Dias, a "interiorização da metrópole". A autora explica:

Com a vinda da Corte, pela primeira vez, desde o início da colonização, configuravam-se nos trópicos portugueses preocupações próprias de uma colônia de povoamento e não apenas de exploração e feitoria comercial, pois que no Rio teriam que viver e, para sobreviver, explorar os enormes recursos naturais e as potencialidades do Império nascente, tendo em vista o fomento do bem-estar da própria população local. (DIAS, 2005, pp. 3334)

Desta maneira, o Rio de Janeiro, que no decorrer do século XVIII transformou-se no principal porto alfandegário do Brasil, passou a sediar o Reino, abrigar os membros da Corte e a despachar as decisões centrais que antes advinham de Lisboa. Não só a cidade carioca, mas todo o território brasileiro experimentou com entusiasmo os ares vindos do velho continente:

A corte e a presença do soberano constituirão um ponto de referência e atração que centraliza no Rio de Janeiro a vida política, administrativa, econômica e financeira da monarquia. Também para boa parte da América meridional a capital brasileira será um centro de atração. (PRADO JR., 1995, p. 129)

Além da presença da Coroa e da nova realidade vivenciada pelo Brasil, de simples território exportador de gêneros primários e minerais para centro político e administrativo do Reino, acreditou-se que as decisões despachadas por D. João VI em muito iriam favorecer a população local: 
Um conjunto de fatores circunstanciais deu à colônia, no começo do século XIX, uma aparência de prosperidade, maior ainda porque a transferência do governo metropolitano e a abertura dos portos, em 1808, criaram um clima geral de otimismo. (FURTADO, 2007, p. 140)

Deste modo, por meio da Carta Regia de 28 de janeiro de 1808, assinado na Bahia e antes mesmo da chegada da Corte ao Rio de Janeiro, criou-se a expectativa que a Colônia finalmente passaria a vivenciar um novo patamar em seu desenvolvimento. Com a abertura dos portos seria promovida a liberdade comercial brasileira e a promessa de uma prosperidade ainda não experimentada. "O antigo sistema colonial, fundado naquilo que se convencionou chamar o pacto colonial, e que representa o exclusivismo do comércio das colônias para as respectivas metrópoles, entra em declínio". (PRADO JR., 1995, p.

Acerca do teor da Carta Regia de 28 de janeiro de 1808, temos:

Conde da Ponte do meu conselho, governador e capitão general da capitania da Bahia. Amigo, eu o príncipe regente vos envio muito saudar, como aquele, que amo. Atendendo, representação que fizestes subir à minha presença, sobre se achar interrompido e suspenso o comércio desta capitania com graves prejuízos dos meus vassalos e de minha fazenda real, em razão das críticas e públicas circunstâncias da Europa, e querendo dar sobre este importante objeto alguma providência pronta e capaz de melhorar os progressos de tais danos: Sou servido ordenar interna e provisoriamente, em quanto não consolido meu sistema geral, que efetivamente regule semelhante matéria, o seguinte:

$1^{\circ}$ - Que sejam admissíveis nas alfândegas do Brasil todo, e quaisquer gêneros, fazendas e mercadorias transportadas ou em navios estrangeiros das potências, que se conservam em paz e harmonia com minha real coroa, ou em navios dos meus vassalos, pagando por entrada, 24\%; a saber: $20 \%$ de direitos grossos e $4 \%$ de donativos já estabelecidos, regulando-se a cobrança destes direitos pelas pautas ou aforamentos, porque até o presente momento se regulam cada uma das ditas alfândegas, ficando os vinhos, aguardentes e azeites doces, que se denominam molhados, pagando o dobro dos direitos, que até agora nelas satisfaziam;

$2^{\circ}$ - Que não só os meus vassalos, mas também os ditos estrangeiros possam exportar para os portos, que bem lhes parecer, a benefício do comércio, e a agricultura, que tanto desejo promover todos, e quaisquer gêneros coloniais, a exceção do pau-brasil, e outros notoriamente estancados, pagando por saída os mesmos direitos já estabelecidos nas referidas capitanias, ficando entretanto como em suspenso, e sem o vigor todas as leis; atos régios ou outras ordens, que até aqui proibiam neste Estado do Brasil o recíproco comércio entre meus vassalos, estrangeiros o que tudo assim fareis executar com o zelo e a atividade que de vós espero. (AMED; NEGREIROS, 2000, p. 179)

De fato, por meio das deliberações provindas da abertura dos portos e das futuras decisões, frutos dos Tratados de Aliança e Amizade e de Comércio e Navegação, firmados 
entre Portugal e Grã-Bretanha em 1810, acreditou-se, mesmo que por um curto espaço de tempo, que enfim o sentido da colonização seria alterado:

(...) queriam firmar o tratado de 1810 e a abertura dos portos de maneira que, promovendo o comércio, pudessem os cultivadores do Brasil achar o melhor consumo para os seus produtos, que daí resultasse o maior adiantamento na geral cultura e povoação deste vasto território. (DIAS, 2005, pp. 33-34)

No entanto, é exatamente neste momento que não devemos nos esquecer dos favores que a potência britânica prestou a Portugal quando da transferência da Corte para o Brasil. Os ingleses, passando pelo processo da Revolução Industrial e necessitando constituir e ampliar seu mercado consumidor, não hesitaram em cobrar a "dívida de honra" contraída pela Coroa lusa. Uma análise mais cuidadosa dos fatos nos evidencia que, tanto a abertura dos Portos, quanto os Tratados de 1810 representaram, em essência, a consolidação dos interesses britânicos em detrimento das necessidades de Portugal e Brasil:

O soberano português concede aí tais favores à sua aliada, que praticamente exclui Portugal do comércio brasileiro. No decreto de abertura dos portos fixara-se um direito geral de importação para todas as nações de $24 \%$ ad valorem. As mercadorias portuguesas seriam beneficiadas pouco depois com uma taxa reduzida de $16 \%$. Pelo tratado de 1810, a Inglaterra obterá uma tarifa de $15 \%$, mais favorável portanto que a própria outorgada a Portugal. (PRADO JR., 1995, pp. 128-129)

De acordo com o observado acerca da determinação das alíquotas de importação constatamos o quanto os produtos ingleses se favoreceram de taxas consideravelmente baixas quando comparadas com os $24 \%$ incidentes sobre as mercadorias das demais "nações amigas".

Ademais, nem mesmo Portugal obtivera o mesmo privilégio, tendo este que pagar um imposto de importação de $16 \%$. Por mais que a diferença seja ínfima, ela ilustra a ideologia incrustada neste evento, que demonstra a supremacia dos interesses ingleses e a imposição de seu poderio econômico frente aos seus parceiros comerciais. Além disso, não ocorreu por parte desta Nação a reciprocidade comercial com seu aliado lusitano:

O tratado de comércio de 1810, referindo-se embora com bonitas palavras ao novo "sistema liberal", constitui, na verdade, um instrumento criador de privilégios. Por outro lado, os ingleses não se preocuparam em abrir mercados aos produtos brasileiros, os quais competiam com os de suas dependências antilhanas. (FURTADO, 2007, p. 145)

Sem embargo, é correto o entendimento acerca das consequências deletérias que tais acordos comerciais geraram para os portugueses recém instalados em um novo território. 
Findo o pacto colonial, a Coroa lusa vê a sua mais importante atividade econômica também desabar e, paralelamente, seu poderio político e comercial construído no decorrer de tantos séculos.

Ademais, ressaltemos que apesar de o Brasil ser propriedade de Portugal há pouco mais de três séculos, uma impotente estrutura administrativa estava instalada na Colônia. Somemos a este fato as necessidades de aprimoramento urbano a serem realizadas para acomodar tão ilustre personagem da história: o príncipe regente.

Certamente tais eventos trariam impactos à precária fiscalidade existente no Brasil, e trouxeram. Chegara a hora de Portugal se deparar com os resultados de suas escolhas passadas e enfrentar mais este problema.

\section{A necessidade de repensar a estrutura tributária}

Diante dos acontecimentos narrados acima façamos um exercício de reflexão acerca das consequências que tais eventos trariam às finanças públicas. A estrutura tributária brasileira construída no decorrer dos séculos se caracterizava pela: a) tributação sobre a produção, principalmente por intermédio dos dízimos; b) impostos incidentes sobre as mercadorias que se direcionavam às minas, as entradas, e; c) a arrecadação proveniente das Alfândegas, a dízima. Em suma, a tributação indireta sobre o consumo.

No momento que nos ocupa, sabemos que tanto a região aurífera quanto a produção e exportação dos gêneros primários destinados aos mercados europeus encontravam-se bem aquém dos seus tempos de glória. Deste modo, eram os impostos alfandegários as principais fontes de receita fiscal existentes em solos brasileiros. Certamente as medidas adotadas por D. João VI trariam consequências para a arrecadação brasileira e sua saúde econômica e financeira:

A "abertura dos portos", decretada ainda em 1808, resultava de uma imposição dos acontecimentos. Vem em seguida os tratados de 1810, que transformam a Inglaterra em potência privilegiada, com direitos de extraterritorialidade e tarifas preferenciais extremamente baixas, tratados esses que constituirão, em toda a primeira metade do século, uma séria limitação à autonomia do governo brasileiro no setor econômico. (FURTADO, 2007, p. 143)

Os Tratados de 1810 representaram um golpe para as finanças brasileiras. A alíquota do imposto de importação de $15 \%$ para os produtos ingleses, principal parceiro comercial de 
Portugal, e agora Brasil, limitou as possibilidades de arrecadação do nascente Império instalado na América.

Além disso, necessitamos enfatizar que a restrição observada na receita veio acompanhada de consideráveis aumentos de gastos provenientes da instalação e manutenção da Corte, e todo o aparato administrativo que a acompanhou:

Transferindo-se para o Brasil, o governo metropolitano trará consigo um complexo aparelhamento administrativo que substituirá bruscamente, sem transição de qualquer espécie, a reduzida administração que até então existia na colônia. Instalam-se aqui grandes repartições públicas e serviços da corte. (...) as pobres finanças da colônia não estavam aparelhadas para tamanhos gastos. (PRADO JR., 1995, pp. 137-138)

Diante desta preocupante situação, queda nas receitas alfandegárias e aumento de gastos, quais alternativas restariam aos dirigentes do Reino? Quais foram as respostas para o problema? O período em pauta observou a criação de novos impostos, bem como a tributação sobre novas bases de incidência. No decorrer deste capítulo apresentaremos a relação dos tributos existentes no ano de 1828 em todo o território nacional. Por meio desta informação será possível averiguar os tributos criados durante o Período Joanino e Primeiro Reinado, bem como inquirir acerca da permanência das receitas fiscais instituídas desde o início da colonização brasileira.

Outro ponto de suma importância e que merece especial atenção é o direcionamento que D. João VI deu à figura do Contratador. Já discutimos largamente no decorrer desta pesquisa a existência dos agentes particulares na arrecadação tributária e os impactos negativos que tal presença acarretava aos cofres públicos, uma vez que significativa parcela do montante arrecadado ficava nas mãos destes senhores. Em um cenário de reorganização das ferramentas disponíveis para otimizar as receitas fiscais é de se esperar reformas também na maneira de promover o recolhimento tributário.

Em 1821 se iniciaram as primeiras medidas a fim de se modificar as formas de cobrança e arrecadação do principal imposto incidente sobre a produção, o dízimo. Por meio do Decreto de 16 de abril de 1821, foi determinado que os dízimos que estivessem administrados ${ }^{27}$ deveriam ser cobrados na entrada das vilas; os dízimos exportados para

\footnotetext{
${ }^{27}$ Os contratos administrados eram aqueles que não possuíam interesse por parte dos Rendeiros. Deste modo, os contratos dos dízimos que estavam sob incumbência administrativa da Coroa eram representados, em grande parte, pela incidência tributária sobre os gêneros de menor representatividade econômica, ou seja, as "miunças".
} 
outras Províncias deveriam ser cobrados nos Registros ou Alfândegas de portos secos, "para ser aplicado o seu produto às indispensáveis despesas das respectivas províncias"; e os dízimos do açúcar, algodão em rama, café, arroz, trigo e fumo,

(...) que são os principais ramos de exportação e comércio exterior deste Reino do Brasil, passarão livremente pelas alfândegas dos portos secos, e do mesmo modo entrarão nas cidades, vilas e povoações, ficando, porém, sujeitos ao pagamento do dízimo na ocasião do embarque dos mesmos gêneros (...). (DECRETO de 16 de abril de 1821)

Pelo mesmo Decreto, estabeleceu-se que os dízimos que se encontrassem contratados não estariam sujeitos, até o final dos contratos, às novas formas de cobrança, e que não mais seriam permitidas prorrogações de contratos já vigentes. Ademais, foram declarados inválidos os contratos já arrematados, mas que ainda não tivessem sido iniciados, de forma a passarem os dízimos, num prazo curso, a serem arrecadados somente pela Coroa. A razão para tal determinação, segundo o Monarca, eram os

(...) gravíssimos inconvenientes, que resultam dos dois métodos até agora adotados para a percepção dos dízimos deste Reino do Brasil, ou por administração, ou por arrematação, e os inexplicáveis males, e vexames, que por qualquer deles sofrem meus fiéis vassalos, sendo o primeiro sumamente dispendioso pelos salários, que absorvem os muitos administradores, necessários em tão extenso território, e raras vezes profícuo pela dificuldade de se encontrar em todos eles a indispensável probidade; e o segundo absolutamente intolerável pelos excessivos lucros, que acumulam em si e seus sócios os arrematantes, o que é de dificílimo remédio, sendo os povos, principalmente da classe indigente, vexados, e perseguidos por grande número de dizimeiros e cobradores, que os forçam à avenças e transações fraudulentas ou excessivas, e os arrastam perante as justiças, fazendo-lhes execuções violentas e sobrecarregadas de custas exorbitantes pelas distâncias dos juízos, e mil rodeios da chicana forense (...). (DECRETO de 16 de abril de 1821)

Deste modo, além de procurar dirimir as nefastas consequências provenientes da violência praticada para a promoção do recolhimento tributário por parte dos Dizimeiros, D. João VI também objetivou com este Decreto o favorecimento das rendas públicas. Ao estabelecer que os dízimos seriam arrecadados nas entradas das vilas, nos Registros, portos secos e Alfândegas, buscou-se a economia com a extinção dos salários despendidos aos administradores, bem como evitar os casos de desvio das verbas recolhidas.

A extinção da função do Contratador do dízimo possuía como intuito promover a concentração da arrecadação deste tributo nas mãos da Coroa, não havendo mais a 
necessidade em compartilhar os lucros da operação com os agentes particulares. Em linhas gerais,

(...) a administração da corte portuguesa no Brasil velará, embora dentro das possibilidades limitadas de um aparelhamento burocrático oneroso, complexo e muitas vezes ineficiente, pelos interesses da colônia. Os resultados, muitas vezes sobrestimados, não deixam, contudo, de contribuir para o desenvolvimento econômico do Brasil; e sobretudo assinalam um primeiro passo nesta grande transformação que se ia operar no país. (PRADO JR., 1995, p. 131)

Dentre os passos que assinalam esta etapa, devemos destacar a deliberação acerca da arrecadação do dízimo deixar de ser efetuada na localidade produtora dos gêneros e passar a ser promovida nos postos de recolhimento tributário situados na entrada das vilas, nas regiões limítrofes entres as Províncias e nas Alfândegas. Tais disposições seriam válidas por três anos, a contar da data do Decreto. Vencido o prazo, as formas de arrecadação existentes anteriormente - a administração e a arrematação - e a forma proposta pelo Decreto deveriam ser comparadas, a fim de se decidir qual dessas deveria prevalecer.

Contudo, devemos destacar que o Decreto de 1821 não foi acatado prontamente pelas Províncias, no decorrer da década de 1820 conflitos foram observados nesta temática. Em síntese, o que se observou no período foi o convívio entre os dois métodos de recolhimento do dízimo, o antigo modelo instaurado pelos Contratos e a nova diretriz estabelecida por meio do Decreto de 16 de abril de 1821.

Por meio desta sistemática o dízimo, com o decorrer do tempo, deixou de ser um imposto incidente sobre a produção e foi se transformando em um imposto civil alfandegário. A base tributária passou a ser a circulação interna provincial, a exportação entre as Províncias e a exportação para fora do Brasil. Todavia, em essência, nunca deixou de ser um tributo que incidia sobre o consumo.

Sendo assim, ledo engano supor que com o fim do Período Colonial ocorreu a extinção do dízimo. O que observamos, em realidade, é a alteração na maneira como o seu recolhimento fora efetuado e, consequentemente, uma nova roupagem dada um velho tributo. De imposto sobre a produção o dízimo passou a incidir sobre a circulação de mercadorias e, no Período Imperial, representou a principal fonte de arrecadação das Províncias exportadoras de gêneros primários, sob a nomenclatura direitos de saída. 
Desta maneira, atribuímos ao Decreto de 16 de abril de 1821 uma importante contribuição no tocante à transformação tributária que o Brasil passou a experimentar nas décadas vindouras. Por meio das determinações estabelecidas no Decreto ocorreu a proibição do recolhimento de impostos nas localidades produtoras, buscando-se coibir os atos de violência oriundos desta prática. Além disso, se objetivou concentrar as rendas dos dízimos nos cofres públicos e com isso procurar melhorar a situação fiscal brasileira. No entanto, como já destacamos, este foi um lento e longo processo transcorrido durante os anos 1820 .

Ademais, tais decisões permitiram a continuidade da existência do dízimo no Brasil. Passados três século, um dos principais mecanismo de recolhimento de impostos continuaria a contribuir substancialmente para as finanças públicas, mas desta vez sob outro título. Esta temática será melhor abordada nas discussões que envolvem o Período Regencial e o Segundo Reinado.

Passados nove dias do Decreto supramencionado, D. João VI retornou a Portugal, em 25 de abril de 1821. Coube ao seu sucessor a tentativa de enfrentar as objeções e resistências advindas das novas deliberações, bem como a resolução dos problemas fiscais e financeiros presentes no Império.

\section{"Independência ou Morte"}

"Se é para o bem de todos e felicidade geral da Nação, estou pronto! Digam ao povo que fico". (D. Pedro I, 1822)

Contrariando as determinações de Portugal, o príncipe regente decide permanecer no Brasil. A Proclamação da Independência veio alguns meses após o "dia do fico" 28 . Assim que assume o trono monárquico, D. Pedro I, sob uma carta de manifesto, registra seu desconforto e preocupação quanto à situação tributária existente no Brasil:

(...) Tereis um sistema de impostos, que respeite os suores da agricultura, os trabalhos da indústria, os perigos da navegação e a liberdade do comércio; um sistema claro e harmonioso, que facilite o emprego e a

${ }^{28} 09$ de janeiro de 1822. 
circulação de cabedais, e arranque as 100 chaves misteriosas que fecham o escuro labirinto das finanças, que não deixam o cidadão lobrigar o rasto do emprego que se dava às rendas da nação. (CARREIRA, 1980, p. 34)

Por meio deste manifesto o príncipe regente reconhece o quanto a estrutura tributária brasileira era confusa e danosa à economia. É correta a afirmativa acerca das medidas adotadas por D. João VI acerca da tentativa em unificar e uniformizar os tributos existentes no Brasil. Todavia, como veremos adiante, muitos tributos existentes eram praticados localmente, as Províncias promoviam o recolhimento tributário de acordo com as atividades econômicas que propiciavam a geração de impostos. No entanto, não devemos nos enganar quanto às bases de incidência, sua parcela mais significativa recaía sobre o consumo, por meio dos tributos sobre os gêneros primários, sobre a circulação alfandegária e sobre a circulação interna de mercadorias.

No tocante às medidas iniciais de D. Pedro com o intuito de melhorar a situação financeira e fiscal do Império, notamos algumas posturas severas direcionadas aos portugueses:

Por decreto de 11 de dezembro de 1822 foi autorizado o sequestro de todas as mercadorias existentes nas alfândegas do império pertencentes aos súditos portugueses; as mercadorias ou suas importâncias em poder dos negociantes portugueses; todos os prédios rústicos e urbanos que possuíam, e finalmente as embarcações ou parte delas pertencentes a negociantes portugueses; sendo excetuadas deste sequestro as ações do Banco Nacional, as das casas de seguros e as da fábrica de ferro da vila de Sorocaba. (CARREIRA, 1980, p. 109)

Além dos sequestros dos bens, o novo governo promoveu alterações na política fiscal. Sobre as importações, principalmente dos produtos oriundos de Portugal, observamos:

Por decreto de 30 de dezembro de 1822 se estabeleceu o imposto de $24 \%$ para o rapé estrangeiro, e bem assim o dos gêneros e mercadorias portuguesas, pagando os vinhos, licores, aguardentes, azeite e vinagre somente os direitos de importação, que ficam sendo por pipa de vinho $12 \$$, do branco $24 \$$, azeite $7 \$$, vinagre $2 \$$, aguardente $36 \$$, licor $36 \$$, vinho tinto por dúzia de garrafas 400 réis, dito branco 800 réis, licor e aguardente 1\$200. (CARREIRA, 1980, p. 109)

No entanto, não somente sobre as tarifas alfandegárias ocorreram modificações. Em fevereiro de 1823 foi expedido um novo Decreto, desta vez promovendo a criação de uma administração incumbida de promover a concentração do recolhimento tributário de importantes impostos existentes no período, a Mesa de Diversas Rendas, situada no Rio de Janeiro:

Por decreto de 4 de fevereiro de 1823 criou-se uma administração junto ao Consulado, incumbida da cobrança, além dos $2 \%$ de exportação dos 
gêneros do país, do dízimo do café e miunças, e de $4 \$$ por pipa de aguardente para consumo; do dízimo do açúcar; de $1 \$$ por pipa de aguardente fabricada no país, de 20 réis de subsídio literário por medida fabricada na província; de $1 \$ 600$ de subsídio por pipa que entrasse na cidade; de 400 réis por arroba de tabaco em corda, da sisa dos bens de raiz; da meia sisa de escravos; do imposto sobre botequins, tabernas, etc., cujo regulamento para arrecadação acompanha o decreto. (CARREIRA, 1980, p. 109)

Neste período as discussões acerca da fiscalidade ocorreram por meio de Decretos. Tais questões não foram contempladas na Constituição promulgada no ano de 1824, primeira do Império do Brasil. Deste modo, o Imperador apresentou seu desconforto quanto aos assuntos fiscais, contudo, optou por não direcionar ao tema a importância que este exigia quando da elaboração da Carta Magna, a Lei suprema e soberana de uma Nação. Tomemos como exemplo os conflitos advindos do Decreto de 16 de abril de 1821 que ainda se faziam presentes, a temática foi tratada somente no ano de 1825:

Tendo a experiência mostrado as dificuldades, inconvenientes e abusos ocasionados pelo método estabelecido pelo $\S 3^{\circ}$ do decreto de 16 de abril de 1821 para a cobrança do dízimo dos gêneros de exportação, e desejando Eu simplificar e facilitar essa arrecadação em benefício da fazenda pública, e maior comodidade dos exportadores, ei por bem ordenar provisoriamente o seguinte (...) que da publicação deste decreto em diante se faça a cobrança do dízimo dos sobreditos gêneros, calculando-se a sua importância pelos preços correntes na ocasião de seu pagamento para serem exportados (...) que os ditos preços correntes sejam regulados em pautas semanárias por corretores ou pessoas de inteligência e crédito na praça. (DECRETO de 31 de maio de 1825)

Intencionando simplificar a sistemática do recolhimento, D. Pedro altera a base de cálculo que geraria o montante a ser tributado. Ao invés de aplicar uma alíquota incidente sobre o valor que foi pago na mercadoria, ficou determinado que seria válido para o recolhimento do imposto o valor de mercado do gênero, por meio dos preços correntes.

Desta maneira, não somente sob a ótica política e econômica, mas também sob a perspectiva fiscal, o Primeiro Reinado representou um período desafiador para os dirigentes e para a Nação brasileira. Havia a necessidade de entender a nova realidade vivenciada, bem como a aceitação e adaptação das deliberações advindas do Rio de Janeiro.

Paralelamente, também é possível observar no período algumas decisões por parte do Imperador que vão na contramão das determinações dadas pelo seu antecessor. No já referido Decreto de 1821 havia o objetivo em concentrar a receita tributária nos cofres públicos, proibindo-se a arrematação de novos contratos sobre a arrecadação dos dízimos. 
Pois bem, os dízimos figuravam entre os principais impostos do período. A extinção dos

Contratadores deste tributo nos faria supor o fim, mesmo que paulatinamente, das arrematações dos contratos como um todo, correto? Não exatamente! Por meio da Lei de 25 de outubro de 1827, D. Pedro I autoriza a arrematação de metade dos direitos das Alfândegas do Império:

Lei de 25 de outubro de 1827 - Manda arrematar metade dos direitos das Alfândegas do Império.

Art. 1 - Arrematar-se-á por uma vez somente em contrato trienal, em cada uma das províncias do Império, a metade dos direitos atuais de entrada, baldeação e reexportação, e dos denominados consulados de saída das respectivas Alfândegas, pelo maior lanço que os licitantes oferecerem sobre o que tiver produzido a metade dos mesmos direitos arrecadados no triênio próximo antecedente, contado de Janeiro a Dezembro, e aumentado de $10 \%$ mais.

Art. 2 - Excetuam-se os direitos de importação impostos sobre os escravos; seja qual for a sua denominação.

Art. 3 - Poderá o Governo especular e contratar com os respectivos rendeiros as condições convenientes ao manejo dos seus contratos, segundo as leis existentes, com salva das seguintes bases:

$1^{\text {a }}$ Que a arrecadação dos ditos direitos continuará a ser feita à boca dos cofres das Alfândegas pelos respectivos Tesoureiros em toda a sua importância, como tem sido até agora.

$2^{\mathrm{a}}$ Que os contratadores receberão à boca dos mesmos cofres no fim de cada mês a metade do rendimento dos mencionados direitos; descontandose $\log$ o a quota parte do pagamento do preço do contrato pertencente à Fazenda Pública neste mesmo mês; e repondo os sobreditos contratadores o que faltar para satisfazer essa parte do preço, ou em dinheiro de contado, ou em letras pagáveis no fim do mês subsequente, as quais letras terão natureza de bilhete da Alfândega;

$3^{\mathrm{a}}$ Que não serão obrigados os contratadores a pagar propina alguma além do preço principal do contrato, nem mesmo a da obra pia; (...). (LEI de 25 de outubro de 1827)

Refletindo sobre a Lei supracitada, algumas indagações se fazem pertinentes: a) Quais teriam sido as motivações que levaram o Imperador a autorizar, no ano de 1827, as arrematações dos contratos de direitos de arrecadação tributária? Não estamos tratando de quaisquer tributos, que porventura não houvesse fiscalização e administração de seus recolhimentos, mas sim das principais fontes de receita tributária do Império, as Alfândegas; b) Teriam sido as pressões dos agentes particulares a origem desta decisão? c) Estaria a circulação alfandegária passando por mais um momento de relativa escassez, fazendo com que o príncipe regente garantisse ao menos uma renda mínima proveniente 
das arrematações? d) Ou seria ainda o caso de não haver uma estrutura administrativa necessária para prover o recolhimento tributário? Caso seja esta a justificativa, como explicar que por meio do Art. $3, \S 2^{\circ}$, ficou estabelecido que os Contratadores receberiam nas bocas dos cofres das Alfândegas, no fim de cada mês, a metade dos rendimentos dos mencionados direitos?

Além disso, ainda no ano de 1827 , a Lei de 13 de novembro regula o modo como se deveriam pagar os preços dos contratos das rendas públicas:

Art. 1 - Os preços dos contratos de arrecadação de rendas públicas, ou venda de próprios alienáveis, cujos pagamentos se houverem de fazer em prestações certas, estipuladas nas arrecadações, serão reduzidos por seus aceitas pelos devedores, sacadas, e endossadas por seus fiadores, e pagáveis nos prazos dos mesmos contratos (...). (LEI de 13 de novembro de 1827)

Desta maneira, é possível concluir que pouco mais de meia década após o Decreto de 1821 a figura do Contratador ainda se fazia presente em solos brasileiros, sendo esta função ponto de atenção dos dirigentes do Império.

Em suma, por mais que no período em voga tenham ocorrido reformas com o intuito de aparelhar e fortalecer a administração pública, bem como a estrutura fazendária, devemos tomar o cuidado de não cair no equívoco em defender que as determinações estabelecidas pelo governo central, sediado no Rio de Janeiro, eliminaram de uma única vez as estruturas coloniais ainda existentes. A herança e o peso histórico ainda se faziam sentir na ex-colônia.

Deste modo, com a vinda da Corte, e posterior Proclamação da Independência, se buscou pensar um novo sistema administrativo para o Brasil. Foi um período no qual as inovações conviveram lado a lado, e até mesmo se confundiram, com a antiga dinâmica existente há séculos.

Entretanto, por mais que houvesse a preocupação em reformar o Brasil e suas bases administrativas, não estava em pauta a alteração da essência tributária brasileira, que era efetuar o recolhimento de impostos por meio da tributação sobre a produção, a circulação e o consumo de mercadorias. O que se objetivou foi otimizar as receitas fiscais. Por mais que neste período tenha ocorrido o início da tributação sobre a renda e a propriedade, estas fontes tributárias tornaram-se de difícil execução devido aos múltiplos interesses 
envolvidos e a falta de fiscalização necessária para concretizar tais receitas. Novamente era a tributação indireta a principal fornecedora de recursos financeiros para o Estado.

Passemos adiante à análise financeira do período, o entendimento dos números e das principais fontes de receita nos auxiliará no conhecimento acerca da realidade vivenciada pelo Brasil na década de 1820.

\section{A saúde financeira do Império no Primeiro Reinado}

Antes de adentrarmos a temática, necessitamos esclarecer quanto a dificuldade em compilar os números apresentados. Não havia no período um critério contábil a ser seguido. Esta realidade foi registrada no relatório do Ministro da Fazenda apresentado aos legisladores, em reunião anual realizada em 1830. No dito relatório, o Marquês de Barbacena apresentou seu desconforto:

Entrando na demonstração do estado do Tesouro, lamenta a imperfeição da escrituração de contabilidade e revisão das contas, havendo muito que aperfeiçoar e criar, principalmente no sistema de fiscalização e publicidade, e dá conta da receita e despesa do ano anterior, mostrando a imperfeição das classificações em ambas, figurando como receita, com a maior impropriedade, verbas que não podiam ter tal classificação. (CARREIRA, 1980, p. 181)

Feitas estas considerações, procuramos expor os balanços financeiros levantados por Carreira a fim de entender as decisões dos agentes políticos e, com isso, compreender os impactos que tais escolhas trouxeram para o âmbito econômico, financeiro e fiscal do país.

Um ponto central que merece atenção é o fato de haver a preocupação entre os legisladores em adequar as receitas às despesas, e não o contrário, como seria de se esperar. Tal aspecto se apresenta logo no início do Império, no ano de 1823:

Longe, porém, de nós a indecisão e o susto no meio de tão grandes embaraços, ponhamos nossas vistas sobre o brilhante futuro que aguarda este nascente império, confiemos na sabedoria da Assembleia Geral Constituinte e Legislativa sobre o estabelecimento da renda pública ordinária com justa e adequada proporção às despesas ordinárias, que forem indispensáveis; e esperamos dela o remédio, que julgar mais eficaz, e próprio às atuais circunstâncias (...). (CARREIRA, 1980, p. 114)

Também data do ano de 1823 o desconforto de D. Pedro I com a temática financeira. Nas palavras do Imperador, em reunião do parlamento realizada em 3 de maio de 1823: 
(...) as circunstâncias do Tesouro Público eram as piores possíveis, ainda mais porque até pouco tempo se limitava o recurso da receita à província do Rio de Janeiro e uma ou outra que recolhia sobras; que o dinheiro era pouco para pagar a credores, e empregados em efetivo exercício; que sendo as despesas da casa de seu pai excedentes de quatro milhões, havia reduzido a sua a um milhão, e que ainda vendo o estado precário do Tesouro limitou-se a receber 110:000\$ para todas as suas despesas; que, não satisfeito de dar o exemplo de economia na sua casa, vigiava sobre todas as repartições modificando suas despesas, e obstando a seus extravios; que sem embargo de tudo as rendas não chegavam para as despesas, mas que os esforços do governo teriam resultado favorável aniquilando maléficas influências que tinham concorrido para este estado de coisas; que o crédito do Banco já se ia restabelecendo, e bem assim o do Tesouro; que apesar de suas demasiadas despesas, ia satisfazendo os seus compromissos, e se falava favoravelmente do seu crédito na Europa. (...) Grandes foram sem dúvida as despesas, mas, contudo, ainda se não lançou mão da caixa dos dons gratuitos, e sequestros das propriedades dos ausentes por opiniões políticas; da caixa do empréstimo, que se contraiu, de 400:000\$ para a compra de vasos de guerra, que se faziam urgentemente necessários para defesa deste Império, o que tudo existe em ser, e da caixa da administração dos diamantes. (CARREIRA, 1980, pp. 109-110)

Desta maneira, ao analisarmos os balanços expostos abaixo, não devemos perder de vista tal realidade. A determinação em adequar as receitas aos gastos nos auxilia no entendimento quanto aos déficits apresentados, bem como nas decisões sobre a utilização recorrente das receitas extraordinárias.

No tocante às despesas, no período de 1823 a 1825 a maior parcela das cifras ficava sob incumbência do Tesouro, pois não havia a repartição por Ministérios:

A distribuição das despesas não se fazia nessa época por ministérios; o Tesouro entregava à repartição da guerra a contribuição destinada ao pagamento das despesas do exército, e à da marinha a destinada ao pagamento das despesas da armada; todas as mais despesas se faziam pelo Tesouro (...). (CARREIRA, 1980, p. 117)

Todavia, são as políticas estabelecidas no campo das receitas que merecem nossa especial atenção, pois é por intermédio destas informações que podemos compreender a dinâmica tributária do período. Observamos no período recorrentes recursos oriundos das receitas extraordinárias, pois as rendas ordinárias não foram suficientes para o suprimento das despesas. Os Quadros e Gráficos expostos abaixo refletem esta realidade. Infelizmente não temos o detalhamento das receitas extraordinárias para todos os anos da série. 
Quadro 26 - Balanco Financeiro do Império, (1823 a 1827)

\begin{tabular}{|c|c|c|c|c|c|}
\hline & 1823 & 1824 & 1825 & 1826 & 1827 \\
\hline Receita ordinária e extraordinária & $3.802: 434 \$ 204$ & $9.618: 197 \$ 318$ & 4.749:090\$608 & $5.393: 944 \$ 911$ & $12.068: 466 \$ 362$ \\
\hline Despesa & $4.702: 434 \$ 206$ & $9.618: 197 \$ 318$ & $8.337: 652 \$ 193$ & $9.408: 888 \$ 999$ & $11.842: 291 \$ 546$ \\
\hline Déficit/Saldo & $(900: 000 \$ 000)$ & - & $(3.608: 561 \$ 589)$ & $(4.004: 944 \$ 088)$ & $226: 175 \$ 086$ \\
\hline \multicolumn{6}{|l|}{ Despesa } \\
\hline Casa imperial e real & $325: 486 \$ 096$ & 292:075\$037 & $250: 532 \$ 992$ & $242: 258 \$ 400$ & \\
\hline Tesouro & $1.298: 863 \$ 413$ & $5.894: 695 \$ 710$ & $2.514: 487 \$ 725$ & & \\
\hline Império & & & & $260: 803 \$ 823$ & $1.691: 404 \$ 617$ \\
\hline Justiça & & & & $93: 478 \$ 670$ & $122: 112 \$ 317$ \\
\hline Estrangeiros & & & & $238: 708 \$ 000$ & $617: 418 \$ 341$ \\
\hline Repartição da marinha / Marinha & $1.710: 169 \$ 309$ & $1.543: 918 \$ 292$ & $1.492: 154 \$ 600$ & $1.837: 583 \$ 470$ & $2.458: 920 \$ 834$ \\
\hline Repartição da guerra / Guerra & $1.353: 917 \$ 226$ & $1.887: 508 \$ 279$ & $1.815: 320 \$ 000$ & $1.706: 678 \$ 616$ & $2.105: 351 \$ 353$ \\
\hline Fazenda & & & & $2.533: 614 \$ 080$ & 4.847:084\$084 \\
\hline Extraordinária & & & $2.285: 156 \$ 876$ & & \\
\hline \multicolumn{6}{|l|}{ Receita } \\
\hline Direitos de importação & $1.851: 100 \$ 959$ & $2.380: 235 \$ 875$ & 2.365:048\$644 & $2.400: 000 \$ 000$ & $2.450: 089 \$ 817$ \\
\hline Direitos de exportação & $486: 683 \$ 876$ & $540: 948 \$ 270$ & $574: 327 \$ 224$ & $600: 000 \$ 000$ & $896: 216 \$ 547$ \\
\hline Despachos marítimos & $12: 662 \$ 000$ & $18: 506 \$ 000$ & $18: 272 \$ 000$ & 23:000\$000 & $21: 428 \$ 000$ \\
\hline Interior & $1.451: 987 \$ 369$ & $2.847: 632 \$ 386$ & $1.513: 498 \$ 999$ & $1.182: 000 \$ 000$ & $3.243: 984 \$ 212$ \\
\hline Extraordinária & & $3.830: 874 \$ 787$ & $277: 943 \$ 741$ & $187: 000 \$ 000$ & $5.456: 748 \$ 056$ \\
\hline \multicolumn{6}{|c|}{ Detalhamento da receita extraordinária } \\
\hline Empréstimo contraído em Londres & & $2.382: 744 \$ 040$ & & & \\
\hline Suprimento feito pelo Banco & & $1.181: 489 \$ 342$ & & & \\
\hline Caixa do empréstimo & $437: 178 \$ 000$ & 439:778\$000 & & & \\
\hline Pela caixa dos sequestros & $100: 563 \$ 495$ & $165: 677 \$ 998$ & & & \\
\hline Subscrição da marinha e guerra & $32: 938 \$ 000$ & $72: 126 \$ 470$ & & & \\
\hline Dons gratuitos & $25: 624 \$ 540$ & $14: 838 \$ 777$ & & & \\
\hline
\end{tabular}

Fonte: (CARREIRA, 1980)

O Quadro 26 nos apresenta a situação financeira no período de 1823 a 1827 . Verificamos que no ano de 1824 o empréstimo contraído em Londres, dentre outras receitas extraordinárias, foi fundamental para que o ano financeiro não encerrasse em déficit ${ }^{29}$.

Ao analisarmos a composição da renda ordinária do período, detectamos serem os direitos de importação e a fonte de receita interior as principais fontes de recursos do Império, excluindo desta análise a receita extraordinária. Dentre três dos cinco períodos analisados, a vanguarda foi ocupada pelos direitos de importação. Ademais, somando os direitos de importação com os direitos de exportação, verificamos serem os impostos alfandegários os mais importantes instrumentos de arrecadação ordinária do período.

\footnotetext{
${ }^{29}$ Optamos por reproduzir os números conforme exposto por Carreira, todavia, alguns desconfortos se fizeram presentes: a) de acordo com o autor, estamos tratando de um balanço. No entanto, nos parece pouco provável que as receitas e despesas tenham sido exatamente iguais; b) Ao efetuarmos o somatório das linhas que compõem a receita extraordinária, no ano de 1824, constatamos que o resultado não confere com o informado no balanço.
} 
Entretanto, não podemos negligenciar a representatividade da renda interior. Suas cifras são consideráveis, o que nos ilustra o dinamismo e a importância da atividade arrecadatória proveniente das transações econômicas ocorridas em solos brasileiros.

Procurando sumarizar o período, o conselheiro Miguel Calmon du Pin Almeida apresentou ao corpo legislativo o seguinte parecer:

Nota o rápido progresso da exportação e o aumento das rendas públicas, e confia nos melhoramentos das vias de comunicação e outros em que se empenhava o país, e que esse progresso continuaria sempre com vantagem, principalmente tendo cessado a guerra [Guerra da Cisplatina, 1825 - 1828, - C.S]; mas acredita que não se poderia debelar o déficit, que oprimia o Tesouro, sem nova operação de crédito e criação de novos tributos, bem como de uma contribuição pessoal e a triplicação do selo; e bem assim sem regular-se a cobrança da décima de herança e legados, e o imposto de botequins, tabernas, etc. Tratando das repartições de Fazenda, acha que estavam organizadas de um modo pouco adaptado ao sistema que regia, notando a lentidão aparatosa das juntas provinciais, falta de uniformidade e bom método de escrituração, confusão e irregularidade no expediente dos negócios, imperfeição ou nulidade do exame moral das contas, e multidão de empregados mesquinhamente pagos. Nota também que as Alfândegas do Império ainda eram regidas pelo Foral de 1587, e tornava-se urgente a confecção de um regulamento e pauta adequada às circunstâncias do país, sendo incompleto e deficiente o que existiam. (CARREIRA, 1980, p. 158)

Deste modo, o Ministro da Fazenda ilustra a realidade vivenciada pelo Brasil nestes primeiros anos do Império. Evidencia as dificuldades em sanar os déficits apresentados, sugerindo como proposta a criação de novos impostos, a regulação da cobrança de alguns outros e a necessidade em reformar o aparelho administrativo instalado. Além disso, não deixa de explanar sobre a importância em rever as leis e regulamentos do Período Colonial ainda presentes e atuantes.

Antes de discorrermos sobre o Quadro 27 e as considerações a respeito do segundo período, 1828 a 1831, precisamos esclarecer quanto a alteração na classificação do ano financeiro e do consequente registro contábil das rendas e despesas.

A partir de 1828 o ano financeiro deixou de acompanhar o calendário, ou seja, janeiro a dezembro. $\mathrm{O}$ início do ano financeiro passou a ser considerando em $1^{\circ}$ de julho, e findo em 30 de junho. Desta maneira, as informações relativas ao primeiro semestre de 1828 , correspondentes aos meses de janeiro a junho, foram informadas à parte. Nas demais colunas foram sumarizados os dados relativos ao primeiro semestre do ano financeiro, julho a dezembro, em união com seu segundo semestre financeiro, janeiro a junho do ano subsequente. 


\section{Quadro 27 - Balanco Financeiro do Império, (1828 a 1831)}

\begin{tabular}{|c|c|c|c|c|}
\hline & $1^{0}$ semestre -1828 & $1828-1829$ & $1829-1830$ & $1830-1831$ \\
\hline Receita ordinária e extraordinária & $7.258: 164 \$ 745$ & $14.406: 240 \$ 205$ & $23.761: 868 \$ 400$ & $22.141: 280 \$ 701$ \\
\hline Despesa & $10.679: 587 \$ 000$ & $13.911: 492 \$ 696$ & 18.213:041\$935 & 19.778:098\$211 \\
\hline Déficit/Saldo & $(3.421: 422 \$ 255)$ & $494: 747 \$ 509$ & $5.543: 826 \$ 466$ & $2.363: 182 \$ 490$ \\
\hline \multicolumn{5}{|l|}{ Despesa } \\
\hline Império & $346: 000 \$ 000$ & $901: 040 \$ 928$ & $1.322: 650 \$ 041$ & $1.298: 548 \$ 055$ \\
\hline Justiça & $138: 655 \$ 000$ & $134: 677 \$ 229$ & $452: 689 \$ 229$ & $455: 497 \$ 370$ \\
\hline Estrangeiros & 140:000\$000 & $300: 364 \$ 710$ & $419: 871 \$ 825$ & $803: 627 \$ 752$ \\
\hline Repartição da marinha / Marinha & $2.567: 000 \$ 000$ & $2.910 .538 \$ 118$ & $3.184: 382 \$ 026$ & $2.349: 435 \$ 550$ \\
\hline Repartição da guerra / Guerra & $3.200: 000 \$ 000$ & $3.649: 016 \$ 836$ & $4.850: 703 \$ 629$ & $4.510: 611 \$ 146$ \\
\hline Fazenda & 4.293:932\$000 & $6.015: 854 \$ 875$ & $7.982: 745 \$ 122$ & $9.885: 547 \$ 656$ \\
\hline \multicolumn{5}{|l|}{ Receita } \\
\hline Direitos de importação & $2.036: 305 \$ 057$ & $6.599: 923 \$ 572$ & $6.273: 345 \$ 577$ & $4.890: 087 \$ 905$ \\
\hline Direitos de exportação & $333: 858 \$ 432$ & $572: 180 \$ 068$ & $1.302: 919 \$ 980$ & $1.578: 950 \$ 455$ \\
\hline Despachos marítimos & $14: 329 \$ 000$ & $63: 287 \$ 545$ & $41: 276 \$ 340$ & $44: 296 \$ 570$ \\
\hline Interior & & $1.922: 500 \$ 061$ & $7.964: 199 \$ 406$ & $6.198: 188 \$ 965$ \\
\hline Extraordinária & & $5.348: 348 \$ 952$ & $9.180: 127 \$ 117$ & $9.429: 756 \$ 806$ \\
\hline Interior e extraordinária & $4.873: 672 \$ 256$ & & & \\
\hline \multicolumn{5}{|l|}{ Figura como receita extraordinária } \\
\hline Cunhagem/Emissão de moeda de cobre & & & $3.495: 278 \$ 360$ & $2.468: 369 \$ 200$ \\
\hline Emissão de apólices da dívida pública & & & $1.918: 200 \$ 000$ & \\
\hline Empréstimo e movimento de fundos & & & $3.711: 561 \$ 116$ & \\
\hline Movimento de fundos & & & & $1.913: 783 \$ 117$ \\
\hline Empréstimos & & & & $502: 312 \$ 473$ \\
\hline Depósitos & & & 106:054\$000 & $477: 472 \$ 757$ \\
\hline É pois a receita ordinária de & & & $15.581: 741 \$ 283$ & $12.711: 515 \$ 895$ \\
\hline
\end{tabular}

Fonte: (CARREIRA, 1980)

O Quadro 27 sintetiza três períodos de superávit financeiro, entretanto, a análise destes dados necessita ser efetuada com cautela. É possível observar, ao menos nos anos de 1829 - 1830 e 1830 - 1831, os números correspondentes a cada uma das ferramentas de receita extraordinária utilizada. Constatamos que a política econômica adotada foi pautada em emissões de moedas e dívidas, por meio de apólices e empréstimos. Sem estes instrumentais não teria sido possível ao governo imperial honrar com suas despesas.

No entanto, em uma perspectiva de médio e longo prazo tais tomadas de decisão não representam as melhores alternativas, pois acarretam severos danos à economia. A emissão de moedas impacta, e impactou, o surto inflacionário. A emissão de apólices e tomada de empréstimos só fez piorar os níveis de dívida pública experimentados pelo Brasil desde o ano de sua independência política, mas jamais independência econômica.

De qualquer maneira, o objetivo final foi alcançado, os anos financeiros apresentaram mais superávits do que déficits, conforme ilustrado no Gráfico 12. 


\section{Gráfico 12 - Despesas e Receitas, (1823 - 1830/1831)}

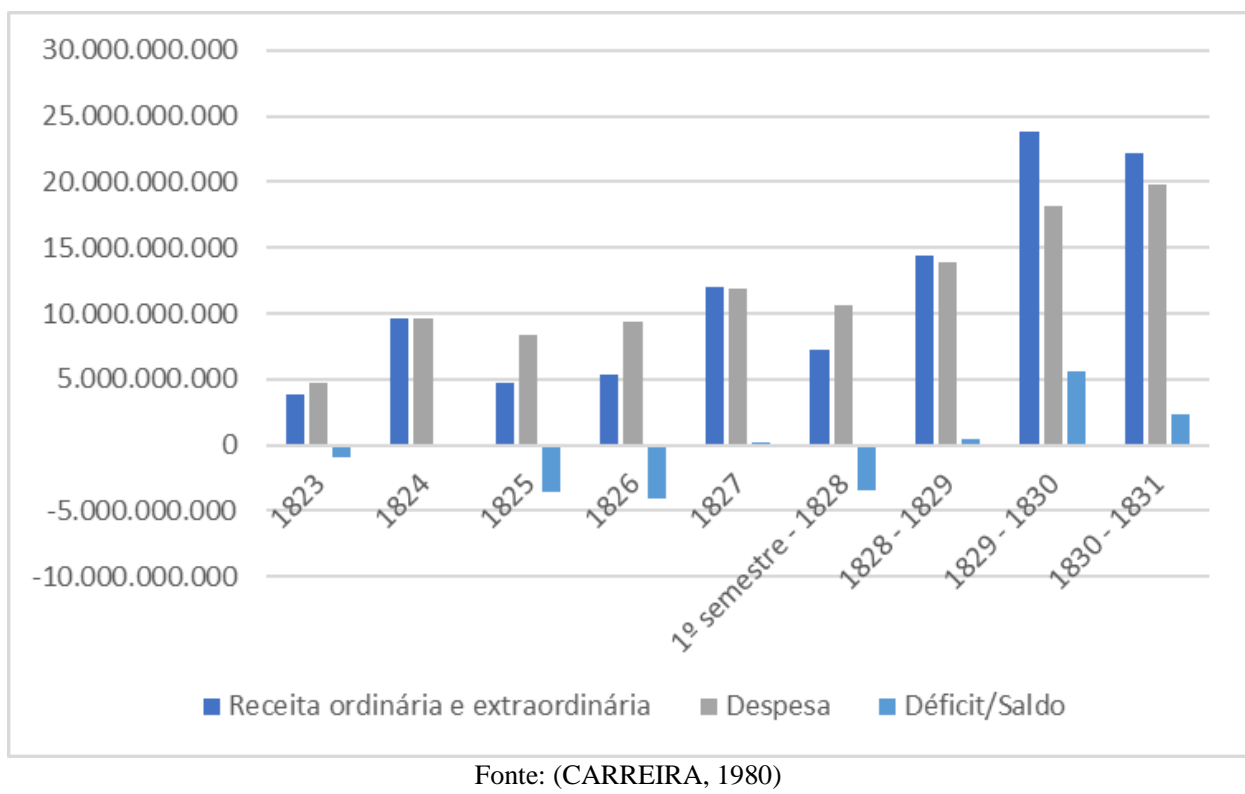

A composição da receita e sua tendência no decorrer do período analisado foi exposto no Gráfico 13. Notamos o quanto os despachos marítimos pouco influenciaram o cômputo geral. Além dele, também é possível constatar a restrita receita oriunda dos direitos de exportação.

\section{Gráfico 13 - Composição da Receita, (1823 - 1830/1831)}

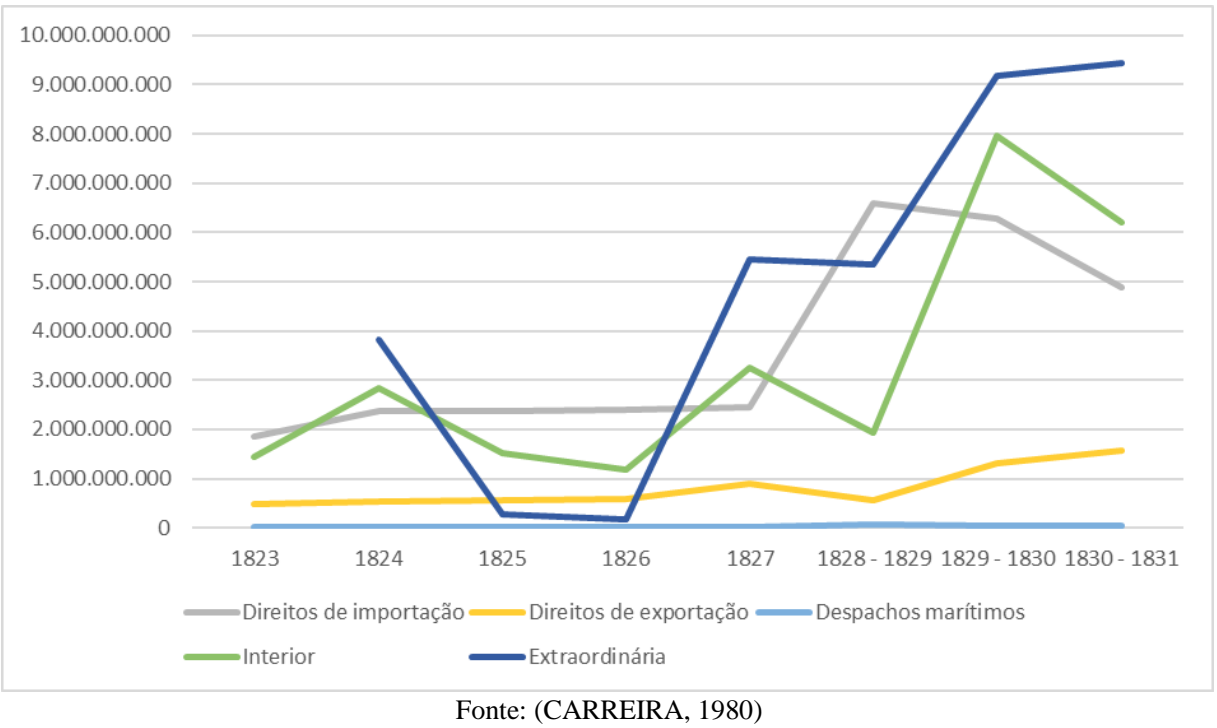

Dentre as rendas ordinárias eram, sem dúvida, os direitos de importação e a receita proveniente do interior as mais importantes fontes de arrecadação tributária 
experimentada pelo Brasil durante o Primeiro Reinado. No entanto, o posto de pioneira coube à receita extraordinária .

Os estudos efetuados neste tópico procuraram ilustrar a situação fiscal do Primeiro Reinado. Por meio dos dados apresentados é possível constatar o quanto a saúde financeira do Brasil estava longe de ser considerada satisfatória. Ao optar pelos constantes recursos provindos das receitas extraordinárias, nossos governantes causaram um cenário de instabilidade econômica e política que já não era tranquilo por si só.

No entanto, os números retratados pouco elucidam acerca da estrutura tributária vigente no país. De fato, é possível averiguar a expressividade arrecadatória dos dados agregados, mas não sua composição. A seguir nos ocuparemos em encaixar mais esta "peça do quebra-cabeça" fiscal brasileiro.

\section{A estrutura tributária no Primeiro Reinado}

As informações disponibilizadas nos Relatórios do Ministério da Fazenda representam uma importante fonte documental para o levantamento da estrutura tributária existente no Primeiro Reinado. Em reuniões anuais os Ministros da pasta apresentavam ao Corpo Legislativo e ao Imperador a situação fiscal do Império.

Deste modo, por intermédio da análise destes relatórios, foi possível consolidar a relação dos tributos existentes em todo o território nacional no ano de 1828, bem como verificar as leis de sua fundação. Optamos por manter a nomenclatura apresentada nos documentos originais, contudo, devemos enaltecer que em alguns casos o que se observa não é exatamente a lei e o ano de constituição do tributo, mas sim a lei que estava regendo determinada receita no ano em pauta. Citemos como exemplo os direitos de $15 \%$ de importação, onde se lê a Lei de 24 de setembro de 1828 como sendo a de sua fundação. Ademais, em muitos casos observamos várias leis regendo o mesmo tributo, a depender da Província na qual havia a incidência da fonte fiscal especificada.

As informações abaixo foram sintetizadas com base nos conteúdos apresentados na Tabela Geral das Rendas e Contribuições Públicas do Império do Brasil, e das Leis de sua fundação, e nas relações apresentadas por cada uma das Tabelas das Rendas da 
Província. Sendo assim, foram compilados os tributos existentes no ano de 1828 das 18 Províncias em somatório com a Tabela Geral.

Quanto à apresentação dos Quadros abaixo sumarizados, efetuamos a organização tributária tendo como norte a base de incidência do tributo. Não levamos em consideração a finalidade do recurso em si, mas antes procuramos analisar qual era a fonte geradora de tal receita.

Deste modo, construímos as seguintes classificações tributárias: Alfândega; Gêneros; Passagens e Registros; Propriedade e Renda; Botequins e Tabernas; Chancelaria; Contratos; Diamante/Ouro e Moeda; e Diversos. Tal classificação foi necessária devido à quantidade de tributos existentes no período, 125 no total. Ademais, a estruturação dos tributos de acordo com sua base de incidência nos permite averiguar com maior rigor e clareza quais eram as atividades econômicas disponíveis para a promoção da arrecadação de receitas.

Notamos que em alguns casos a denominação do imposto aparece de maneira divergente entre as Províncias, entretanto, a lei de sua fundação e a quotização nos permitiu concluir tratar-se do mesmo tributo. Nestas situações, optamos por reproduzir as denominações apresentadas em cada uma das Províncias a fim de podermos constatar que estamos tratando da mesma fonte de arrecadação, embora com outra nomenclatura. Além disso, em outros casos é possível observar que a mesma atribuição tributária possui uma base de incidência diferente entre as localidades.

O Quadro 28 ilustra os tributos incidentes sobre a Alfândega, principal mecanismo de recolhimento tributário no período, conforme demonstrado acima. Nesta relação constam as incidências fiscais sobre a importação e exportação de gêneros, mercadorias e escravos e os despachos alfandegários. Há 31 mecanismos de arrecadação listados nesta categoria:

Quadro 28 - Relacão dos Tributos Incidentes sobre a Alfândega, (1828)

\begin{tabular}{|l|l|c|l|}
\hline \multicolumn{1}{|c|}{ Tributo } & Lei da sua fundação & Província & Quotização (\%, moeda corrente e/ou base de incidência) \\
\hline $\begin{array}{l}\text { Amarração do } \\
\text { Anilo do Porto }\end{array}$ & $\begin{array}{l}\text { Provisão do Tesouro de } \\
18 \text { de agosto de 1820 }\end{array}$ & CE & $1 \$ 000$ réis diários que pagam os navios. \\
\hline $\begin{array}{l}\text { Ancoragem } \\
\text { Navios } \\
\text { Estrangeiros }\end{array}$ & $\begin{array}{l}\text { Aviso da Marinha de } 24 \\
\text { de junho de } 1804 \text { (BA); } \\
\text { Decreto de 15 de março } \\
\text { de 1810; Decreto de 15 } \\
\text { de março de 1820 (BA) }\end{array}$ & $\begin{array}{c}\text { RJ, ES, BA, } \\
\text { SE, AL, PE, } \\
\text { PA, SP, SC },\end{array}$ & $\begin{array}{l}1 \$ 000 \text { réis diários de cada embarcação estrangeira estacionada } \\
\text { neste Porto. }\end{array}$ \\
\hline
\end{tabular}




\begin{tabular}{|c|c|c|c|}
\hline Capatazias & \begin{tabular}{|l} 
Alvará de 25 de abril de \\
1818
\end{tabular} & RJ, BA, CE & $\begin{array}{l}\text { BA - } 240 \text { réis por volume; } 160 \text { réis por volume pequeno; e } 80 \\
\text { réis por volume menor. }\end{array}$ \\
\hline $\begin{array}{l}\text { Contribuição de } \\
30 \text { réis no Trigo }\end{array}$ & $\begin{array}{l}\text { Aviso de } 19 \text { de agosto } \\
\text { de } 1815\end{array}$ & RJ & $\begin{array}{l}30 \text { réis em alqueire de trigo na saída dos Trapiches em que se } \\
\text { arrecada. }\end{array}$ \\
\hline $\begin{array}{l}\text { Direito de } 3 \$ 500 \\
\text { réis por Escravo } \\
\text { Importado }\end{array}$ & $\begin{array}{l}\text { Carta Regia de } 10 \text { de } \\
\text { janeiro de } 1699\end{array}$ & PE & $\begin{array}{l}\text { São dobrados quando não fazem escala nos Portos de S. } \\
\text { Thomé e Príncipe. }\end{array}$ \\
\hline $\begin{array}{lr}\text { Direitor } & \text { dos } \\
\text { Escravos de Saída } \\
\text { dos } & \text { Portos } \\
\text { Africanos } & \end{array}$ & $\begin{array}{l}\text { Ordem do Conselho } \\
\text { Ultramarino de } 09 \text { de } \\
\text { setembro de } 1724, \\
\text { ampliada pelo Aviso de } \\
22 \text { de junho de } 1810\end{array}$ & RJ, PA & $\begin{array}{l}\text { RJ - } 8 \$ 700 \text { réis por cada escravo importado, e } 4 \$ 350 \text { réis por } \\
\text { cada escravo importado de } 4 \text { palmos para baixo. }\end{array}$ \\
\hline $\begin{array}{l}\text { Direitos da Ponte } \\
\text { da Alfândega }\end{array}$ & Estabelecido em 1776 & RS & $6 \$ 000$ réis por saída de navio. \\
\hline $\begin{array}{l}\text { Direitos de } 1 \$ \text { réis } \\
\text { por Escravo } \\
\text { Importado }\end{array}$ & $\begin{array}{l}\text { Portaria de } 25 \text { de junho } \\
\text { de } 1722\end{array}$ & PE & $\begin{array}{l}\text { São dobrados quando não fazem escala nos Portos de S. } \\
\text { Thomé e Príncipe. }\end{array}$ \\
\hline $\begin{array}{l}\text { Direitos de } 15 \% \text { de } \\
\text { Importação }\end{array}$ & $\begin{array}{l}\text { Lei de } 24 \text { de setembro } \\
\text { de } 1828\end{array}$ & $\begin{array}{l}\text { RJ, ES, BA, } \\
\text { SE, AL, PE, } \\
\text { PB, RN, CE, } \\
\text { PI, MA, PA, } \\
\text { SP, SC, RS }\end{array}$ & A quota é a denominação da renda. \\
\hline $\begin{array}{l}\text { Direitos de } 2 \% \text { da } \\
\text { Exportação }\end{array}$ & $\begin{array}{l}\text { Alvará de } 25 \text { de abril de } \\
1818\end{array}$ & $\begin{array}{l}\text { RJ, ES, BA, } \\
\text { SE, AL, PE, } \\
\text { PB, CE, PI, } \\
\text { MA, PA, SP, } \\
\quad \text { SC, RS }\end{array}$ & $\begin{array}{l}2 \% \text { deduzidos dos gêneros exportados, depois de pagos os } \\
\text { respectivos dízimos. }\end{array}$ \\
\hline 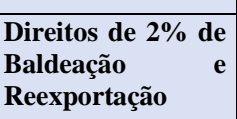 & $\begin{array}{l}\text { Lei de } 25 \text { de setembro } \\
\text { de } 1828\end{array}$ & $\begin{array}{l}\text { RJ, BA, AL, } \\
\text { PE, CE, MA }\end{array}$ & A quota é a denominação da renda. \\
\hline 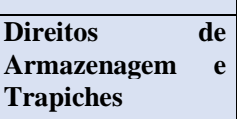 & $\begin{array}{l}\text { Alvará de } 26 \text { e maio de } \\
1812\end{array}$ & RJ & $\begin{array}{l}2 \% \text { no valor das mercadorias recolhidas nos Armazéns, sendo } \\
\text { estrangeiras, e das mais conforme a prática do país. }\end{array}$ \\
\hline $\begin{array}{l}\text { Direitos de } \\
\text { Charque } \\
\text { Exportado }\end{array}$ & $\begin{array}{l}\text { Alvará de } 25 \text { de abril de } \\
1818\end{array}$ & RS & $\begin{array}{l}600 \text { réis por arroba para portos estrangeiros e } 200 \text { réis por dito } \\
\text { sendo em navio nacional. }\end{array}$ \\
\hline $\begin{array}{lr}\text { Direitos de } & \text { Ditos } \\
\text { Novíssimos } & / \\
\text { Imposto de } & \text { \$ réis } \\
\text { de } & \text { Entrada } \\
\text { cada } & \text { Escravo } \text { (BA } \\
\text { / PE) / Direitos dos } \\
\text { Escravos r de } \\
\text { Entrada dos } \\
\text { Portos Africanos }\end{array}$ & $\begin{array}{l}\text { Alvará de } 25 \text { de abril de } \\
\text { 1818; Alvará de } 15 \text { de } \\
\text { abril de } 1818 \text { (CE / RS) }\end{array}$ & $\begin{array}{l}\text { RJ, BA, PE, } \\
\text { CE, MA, PA, } \\
\text { RS }\end{array}$ & $9 \$$ réis por escravo importado. \\
\hline Direitos de Farol & $\begin{array}{|lrr|}\begin{array}{l}\text { Decreto } \\
\text { dezembro de }\end{array} 1819 & \text { de } \\
\end{array}$ & $\begin{array}{l}\text { BA, SE, AL, } \\
\text { PE, MA, PA }\end{array}$ & 100 réis por tonelada na saída das embarcações. \\
\hline $\begin{array}{l}\text { Direitos de } \\
\text { Guindaste }\end{array}$ & $\begin{array}{l}\text { Provisão de } 12 \text { de } \\
\text { fevereiro de } 1811 ; \\
\text { Portaria da Junta de } \\
1814 \text { (MA) }\end{array}$ & RJ, PE, MA & $\begin{array}{l}\text { RJ - Por descarga de Barca grande, } 8 \$ \text { réis; de dita pequena, } \\
6 \$ \text { réis; de Saveiro grande, } 3 \$ 200 \text { réis. De dito pequeno, } 1 \$ 920 \\
\text { réis; de Lancha, } 1 \$ 280 \text { réis; de meia dita, } 640 \text { réis; Lingada } \\
\text { para cima, } 160 \text { réis; para baixo, } 80 \text { réis. }\end{array}$ \\
\hline $\begin{array}{lr}\text { Direitos } & \text { de } \\
\text { Imposição } & \text { e } \\
\text { Exportação } & \end{array}$ & $\begin{array}{l}\text { Provisão de } 07 \text { de abril } \\
\text { de } 1818\end{array}$ & MT & Procede do comércio com as Províncias espanholas. \\
\hline $\begin{array}{l}\text { Direitos } \\
\text { Denominados } \\
\text { Territoriais } \\
\text { Direitos } \\
\text { Territoriais por } \\
\text { Exportação }\end{array}$ & $\begin{array}{l}\text { Aviso de } 07 \text { de maio de } \\
1803\end{array}$ & RS & $\begin{array}{l}\text { Aguardente da terra por pipa, } 4 \$ 000 \text { réis; Dita estrangeira, } \\
2 \$ 400 \text { réis; Dita de vinho, } 2 \$ 400 \text { réis; Vinagre, } 2 \$ 400 \text { réis; } \\
\text { Azeite doce, } 2 \$ 400 \text { réis; Pano de algodão, vara, } 5 \text { réis; Açúcar } \\
\text { branco, } 320 \text { réis; Açúcar mascavo, } 200 \text { réis; Café, } 100 \text { réis; } \\
\text { Pano em rolo, } 480 \text { réis; Farinha de mandioca, alqueire, } 50 \text { réis; } \\
\text { Arroz pilado, } 100 \text { réis; Escravos, } 12 \$ 000 \text { réis. }\end{array}$ \\
\hline
\end{tabular}




\begin{tabular}{|c|c|c|c|}
\hline $\begin{array}{lr}\text { Dízima } & \text { dos } \\
\text { Gêneros do } & \text { País } \\
\text { que se exportam }\end{array}$ & $\begin{array}{l}\text { Carta Regia de } 10 \text { de } \\
\text { novembro de } 1709\end{array}$ & BA & $10 \%$ em todo o gênero de produção do país. \\
\hline $\begin{array}{l}\text { Emolumentos de } \\
\text { Arqueações, } \\
\text { Visitas e Vistorias }\end{array}$ & $\begin{array}{l}\text { Incorporados } \\
\text { extinção do Ofício de } \\
\text { Patrão Mor da Bahia, } \\
\text { pelo Alvará de } 15 \text { de } \\
\text { novembro de } 1802\end{array}$ & BA & $\begin{array}{l}4 \$ 000 \text { réis por entrada e saída de vasos estrangeiros; } 2 \$ 000 \\
\text { réis por visita; } 2 \$ 000 \text { réis por arqueação e } 2 \$ 000 \text { réis por } \\
\text { vistoria. }\end{array}$ \\
\hline $\begin{array}{l}\text { Imposição de } 480 \\
\text { réis nos Guardas } \\
\text { de Embarque }\end{array}$ & $\begin{array}{l}\text { Portaria de } 13 \text { de maio } \\
\text { de } 1822\end{array}$ & PE & - \\
\hline $\begin{array}{l}\text { Imposto das } \\
\text { Caixas e Feixos de } \\
\text { Açúcar }\end{array}$ & $\begin{array}{l}\text { Carta Regia de } 04 \text { de } \\
\text { novembro de } 1700\end{array}$ & PB & 400 réis por caixa; 200 réis por feixo que se exportam. \\
\hline $\begin{array}{l}\text { Imposto de } 10 \$ \\
\text { réis de Entrada de } \\
\text { cada Escravo }\end{array}$ & - & BA & $\begin{array}{l}\text { Pela Carta Regia de } 10 \text { de janeiro de } 1699 \text { - } 3 \$ 500 \text { réis; Portaria } \\
\text { do Vice-Rei de } 1722 \text { - } 1 \$ 000 \text { réis; Carta Regia de } 27 \text { de maio } \\
\text { de } 1757 \text { - } 2 \$ 500 \text { réis de Subsídio Voluntário; Carta Regia de } \\
19 \text { de maio de } 1799 \text { - } 3 \$ 000 \text { réis de Novo Imposto. }\end{array}$ \\
\hline $\begin{array}{l}\text { Imposto dos } \\
\text { Couros em Cabelo }\end{array}$ & $\begin{array}{l}\text { Carta Regia de } 18 \text { de } \\
\text { março de } 1801\end{array}$ & $\mathrm{PE}$ & 50 réis por couro que se exporta. \\
\hline $\begin{array}{lr}\text { Marca } & \text { dos } \\
\text { Volumes } & \text { da } \\
\text { Alfândega } & \end{array}$ & $\begin{array}{l}\text { Decreto de } 02 \text { de março } \\
\text { de } 1797\end{array}$ & MA & 80 réis por volume que catra na Alfândega. \\
\hline $\begin{array}{lr}\text { Meio por } & \text { cento } \\
\text { sobre } & \text { as } \\
\text { Assinaturas } & \text { da } \\
\text { Alfândega } & \end{array}$ & $\begin{array}{l}\text { Lei de } 23 \text { de outubro de } \\
1827\end{array}$ & RJ & A quota é a denominação da renda. \\
\hline $\begin{array}{l}\text { Pensões de Caixas } \\
\text { e Feixos de Açúcar }\end{array}$ & $\begin{array}{l}\text { Instituídas pelos } \\
\text { extintos Donatários }\end{array}$ & PE, PB & 80 réis por caixa; 40 réis por feixo de açúcar exportado. \\
\hline Selo das Fazendas & $\begin{array}{l}\text { Foral de } 1646 \text {; Provisão } \\
\text { de } 10 \text { de julho de } 1720 \\
\text { (BA); Decreto de } 12 \text { de } \\
\text { novembro de } 1822 \\
\text { (MA); Lei de } 10 \text { de } \\
\text { outubro de } 1828\end{array}$ & $\begin{array}{l}\text { RJ, BA, PE, } \\
\text { MA, PA }\end{array}$ & $\begin{array}{l}\text { RJ - } 10 \text { réis que paga cada uma peça de mercadoria que entra } \\
\text { na Alfândega; BA - } 12 \text { réis de cada Selo que se imprime nas } \\
\text { Fazendas Secas. }\end{array}$ \\
\hline $\begin{array}{l}\text { Subsídio / Imposto } \\
\text { do Algodão }\end{array}$ & $\begin{array}{l}\text { Carta Regia de } 28 \text { de } \\
\text { julho de } 1808\end{array}$ & $\begin{array}{l}\text { BA, AL, PE, } \\
\text { PB, CE, PI, } \\
\text { MA, PA }\end{array}$ & 600 réis por arroba de algodão exportado. \\
\hline \begin{tabular}{lr|} 
Subsídio & das \\
Carnes & Secas / \\
Subsídio Militar \\
das Carnes
\end{tabular} & $\begin{array}{l}\text { Carta Regia de } 15 \text { de } \\
\text { maio de } 1654\end{array}$ & AL, PE, RN & 160 réis por arroba de carne importada. \\
\hline $\begin{array}{l}\text { Subsídio do } \\
\text { Tabaco em Rama }\end{array}$ & Estabelecido em 1630 & $\mathrm{PE}$ & 160 réis por arroba de tabaco que se despacha. \\
\hline
\end{tabular}

Fonte: (Relatório do Ministério da Fazenda, 1828)

A seguir são apresentadas as receitas fiscais oriundas da incidência sobre os gêneros, seja sobre a produção interna das mercadorias, sua venda ou seu consumo. Dentro desta classificação se encontra o dízimo, principal instrumento de arrecadação da receita interior. Quanto a este tributo, necessitamos esclarecer que no ano de 1828 somente a Província do Rio de Janeiro seguia as diretrizes do Decreto de 16 de abril de 1821. O Rio Grande do Sul obedecia as determinações estabelecidas pela Provisão do Conselho da Fazenda de 10 de março de 1823 e as demais 16 Províncias se pautavam na Carta Regia 
de 18 de março de 1715. Além deste fato, também é interessante notar a existência, no ano de 1828, do tributo incidente sobre o pau-brasil. Assim como no Quadro 28, o

Quadro 29 também é composto por 31 fontes tributárias:

\section{Quadro 29 - Relação dos Tributos Incidentes sobre os Gêneros, (1828)}

\begin{tabular}{|c|c|c|c|}
\hline Tributo & Lei da sua fundação & Província & Quotização (\%, moeda corrente e/ou base de incidência) \\
\hline $\begin{array}{l}4 \% \text { do Gado de Ilha } \\
\text { Joannes }\end{array}$ & $\begin{array}{l}\text { Provisão de } 2 \text { de junho } \\
\text { de } 1728 ; \text { Termo de } 04 \text { de } \\
\text { maio } 1757\end{array}$ & PA & $\begin{array}{l}\text { Deduzidos das fazendas dos proscritos Jesuítas, dos } \\
\text { Mercenários e do Carmo. }\end{array}$ \\
\hline Bebidas de Garapas & Estabelecido em 1727 & $\mathrm{PE}$ & É o privilégio exclusivo de vender garapas de mel e açúcar. \\
\hline $\begin{array}{l}\text { Contribuição da } \\
\text { Junta do Comércio }\end{array}$ & $\begin{array}{l}\text { Alvará de } 15 \text { de julho de } \\
1809\end{array}$ & BA, MA, PA & $\begin{array}{l}\text { BA - } 160 \text { réis para caixa de açúcar; } 40 \text { réis por feixo; } 100 \text { réis } \\
\text { por saca; } 20 \text { réis por couro; } 10 \text { réis por dito refogado; } 40 \text { réis } \\
\text { em rolo de tabaco; e } 1 \$ 500 \text { por despacho de navio. }\end{array}$ \\
\hline $\begin{array}{l}\text { Contribuição de } 40 \\
\text { réis no Sal Brasileiro } \\
\text { / Imposto de } 80 \text { réis } \\
\text { em Alqueire de Sal } \\
\text { (ES / AL) / Direitos } \\
\text { do Sal }\end{array}$ & $\begin{array}{l}\text { Decreto de } 11 \text { de maio } \\
\text { de } 1821 \quad \text { (ES); } \\
\text { Resolução de Consulta } \\
\text { de } 26 \text { de novembro de } \\
\text { 1827; Provisão de } 10 \text { de } \\
\text { dezembro de } 1827 \text { (CE) }\end{array}$ & $\begin{array}{l}\mathrm{RJ}, \mathrm{ES}, \mathrm{AL}, \\
\mathrm{CE}\end{array}$ & $\begin{array}{l}\mathrm{RJ} \text { - } 40 \text { réis por alqueire de produção do país; ES - A quota é a } \\
\text { denominação da renda; CE - } 75 \text { réis por alqueire do sal } \\
\text { estrangeiro e } 40 \text { réis pelo brasileiro. }\end{array}$ \\
\hline $\begin{array}{l}\text { Contribuição } \\
\text { Literária } \\
\text { Marinha e } \\
\text { Secos }\end{array}$ & $\begin{array}{l}\text { Aviso de } 20 \text { de julho de } \\
1801\end{array}$ & SP & $\begin{array}{l}\text { Açúcar, arroba - } 40 \text { réis; Café - } 80 \text { réis; Fumo - } 80 \text { réis; } \\
\text { Toucinho e Banha - } 40 \text { réis; Goma - } 50 \text { réis; Dita por alqueire } \\
\text { - } 100 \text { réis; Algodão em rama, arroba - } 80 \text { réis; Dito em pano, } \\
\text { vara - } 3 \text { réis; Arroz pilado - } 20 \text { réis; Dito em casca, alqueire - } \\
20 \text { réis; Dito sem casca, dito - } 40 \text { réis; Feijão dito - } 30 \text { réis; } \\
\text { Milho dito - } 10 \text { réis; Congonha dita - } 80 \text { réis; } 240 \text { réis por } \\
\text { cabeça de gado e porco exportado para o Rio de Janeiro, e que } \\
\text { não tenha pago o Novo Imposto em Sorocaba. } \\
\text { Semelhantemente, } 160 \text { réis por cada potro ou besta; e sendo } \\
\text { para outras Províncias cada potro } 200 \text { réis e cada besta } 320 \\
\text { réis. }\end{array}$ \\
\hline $\begin{array}{l}\text { Contribuição para a } \\
\text { Conquista } \\
\text { Garapuava }\end{array}$ & $\begin{array}{l}\text { Carta Regia de } 01 \text { de } \\
\text { abril de } 1809\end{array}$ & SP & $\begin{array}{l}\text { De cada besta muar criada até a Vila de Sorocaba, } 875 \text { réis; de } \\
\text { cada cavalo, } 750 \text { réis; de cada cabeça de gado vacum, } 240 \text { réis. } \\
\text { Porém, sendo criados no Sul, Vacaria e Lages, arrecada-se de } \\
\text { cada uma } 160 \text { réis, e cada cavalo } 220 \text { réis. }\end{array}$ \\
\hline $\begin{array}{l}\text { Dízima da } \\
\text { Aguardente }\end{array}$ & $\begin{array}{l}\text { Carta Regia de } 10 \text { de } \\
\text { novembro de } 1709 \\
\text { (BA); Carta Regia de } 27 \\
\text { de maio de } 1757\end{array}$ & BA & $1 \$ 600$ por pipa. \\
\hline $\begin{array}{l}\text { Dízima das } \\
\text { Madeiras }\end{array}$ & $\begin{array}{l}\text { Portaria de } 5 \text { de março } \\
\text { de } 1802\end{array}$ & SP & $\begin{array}{l}\text { Deduz-se das madeiras produzidas nas Vilas de Paranaguá e } \\
\text { Antonina. }\end{array}$ \\
\hline Dízima do Tabaco & $\begin{array}{l}\text { Carta Regia de } 10 \text { de } \\
\text { novembro de } 1709 \\
\text { (BA); Carta Regia de } 27 \\
\text { de maio de } 1757\end{array}$ & BA & 80 réis em arroba de tabaco. \\
\hline $\begin{array}{l}\text { Dízimos / Dízimos de } \\
\text { Miunças, do Açúcar, } \\
\text { Café, Pescado, } \\
\text { Algodão, Algodão } \\
\text { em Rama, Tabaco, } \\
\text { Sal, Arroz e Gado }\end{array}$ & $\begin{array}{l}\text { Carta Regia de } 18 \text { de } \\
\text { março de } 1715 \text {; Decreto } \\
\text { de } 16 \text { de abril de } 1821 \\
\text { (RJ); Provisão do } \\
\text { Conselho da Fazenda de } \\
10 \text { de março de } 1823 \\
\text { (RS) }\end{array}$ & $\begin{array}{l}\text { RJ, ES, BA, } \\
\text { SE, AL, PE, } \\
\text { PB, RN, CE, } \\
\text { PI, MA, PA, } \\
\text { SP, SC, RS, } \\
\text { MG, GO, MT }\end{array}$ & $\begin{array}{l}\text { RJ - } 10 \% \text { sobre o valor do gênero, conforme o Decreto de } 16 \\
\text { de abril de } 1821 \text {; RS - Trigo por alqueire, } 100 \text { réis; Charque } \\
\text { por arroba, } 60 \text { réis; Sebo dito, } 80 \text { réis; Graxa dito, } 80 \text { réis; Mate } \\
\text { dito, } 60 \text { réis; Couro vacum em cabelo, } 80 \text { réis; Dito cavalar, } 40 \\
\text { réis. N.B - sendo gado em pé exportado: por cabeça } 400 \text { réis e } \\
240 \text { réis de Quinto. }\end{array}$ \\
\hline
\end{tabular}




\begin{tabular}{|c|c|c|c|}
\hline $\begin{array}{l}\text { Donativos das } \\
\text { Caixas e Feixos de } \\
\text { Açúcar e Tabaco }\end{array}$ & $\begin{array}{l}\text { Carta Regia de } 04 \text { de } \\
\text { fevereiro de } 1662\end{array}$ & BA & $\begin{array}{l}380 \text { réis por caixa; } 140 \text { réis por feixo; e } 70 \text { réis em rolo de } \\
\text { tabaco. }\end{array}$ \\
\hline Gado do Evento & $\begin{array}{l}\text { Ord. L. } 2^{\circ} \text {, tt. } 26 \text { §. 17; } \\
\text { Alvará de } 4 \text { de } \\
\text { dezembro de } 1713(\mathrm{CE}) ; \\
\text { Ordenação da Junta de } 2 \\
\text { de junho de } 1728(\mathrm{~PB})\end{array}$ & $\mathrm{PE}, \mathrm{PB}, \mathrm{CE}$ & PB - No gado vacum e cavalar que se acha sem marca. \\
\hline $\begin{array}{l}\text { Imposição de } 5 \text { réis } \\
\text { em libra de Carne } \\
\text { Verde }\end{array}$ & $\begin{array}{l}\text { Alvará de } 03 \text { de junho } \\
\text { de } 1809\end{array}$ & $\begin{array}{c}\text { RJ, ES, BA, } \\
\text { SE. AL, PE, } \\
\text { PB, RN, CE, } \\
\text { PI, MA, PA, } \\
\text { SP, SC, RS, } \\
\text { MG, GO, MT }\end{array}$ & A quota desta renda é a mesma da denominação. \\
\hline 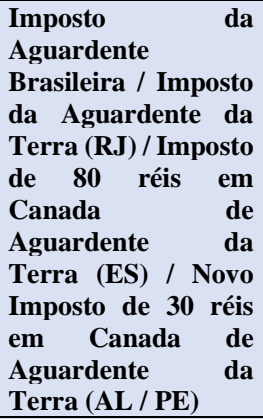 & $\begin{array}{l}\text { Carta Regia de } 23 \text { de } \\
\text { outubro de } 1646 \text { (ES); } \\
\text { Carta Regia de } 21 \text { de } \\
\text { dezembro de } 1692 ; \\
\text { Carta Regia de } 18 \text { de } \\
\text { março de } 1801 \text { (AL / } \\
\text { PE) }\end{array}$ & $\begin{array}{l}\mathrm{RJ}, \mathrm{ES}, \mathrm{AL}, \\
\mathrm{PE}\end{array}$ & $\begin{array}{l}\text { RJ - } 1 \$ 600 \text { réis em Pipa; ES - A quota é a denominação da } \\
\text { renda; AL / PE - } 30 \text { réis por canada de aguardente fabricada no } \\
\text { país. }\end{array}$ \\
\hline $\begin{array}{l}\text { Imposto da } \\
\text { Aguardente } \\
\text { Denominado } \\
\text { Equivalente } \\
\end{array}$ & $\begin{array}{l}\text { Alvará de } 10 \text { de janeiro } \\
\text { de } 1757\end{array}$ & RJ & $1 \$ 000$ réis em Pipa. \\
\hline $\begin{array}{l}\text { Imposto de } 40 \text { réis } \\
\text { por Pesada; e } 20 \text { réis } \\
\text { por Saco de Algodão }\end{array}$ & $\begin{array}{l}\text { Carta Regia de } 15 \text { de } \\
\text { maio de } 1820\end{array}$ & $\mathrm{PE}$ & A quota é a denominada na renda. \\
\hline $\begin{array}{lr}\text { Imposto de } \\
\text { Aguardente de } \\
\text { Consumo (RJ/RN) / } \\
\text { Imposto de 8\$ réis } \\
\text { em Pipa de } \\
\text { Aguardente; Dito de } \\
4 \text { \% réis (ES) } \\
\end{array}$ & $\begin{array}{l}\text { Alvará de } 30 \text { de maio de } \\
1820 ; \text { Resolução de } \\
\text { Consulta de } 04 \text { de } \\
\text { fevereiro de } 1822\end{array}$ & $\begin{array}{l}\text { RJ, ES; BA, } \\
\text { SE, AL, PE, } \\
\text { PB, RN, CE, } \\
\text { PI }\end{array}$ & $\begin{array}{l}\mathrm{RJ} \text { - } 4 \$ 000 \text { réis em Pipa; ES / BA / SE / AL / PE / PB / RN / } \\
\mathrm{CE} / \mathrm{PI} \text { - A quota é a denominação da renda. }\end{array}$ \\
\hline $\begin{array}{l}\text { Imposto de Tabaco } \\
\text { em Pó }\end{array}$ & $\begin{array}{l}\text { Carta Regia de } 18 \text { de } \\
\text { março de } 1801\end{array}$ & $\mathrm{PE}$ & 80 réis por libra que se fabrica na Província. \\
\hline $\begin{array}{l}\text { Imposto do Tabaco } \\
\text { de Corda }\end{array}$ & $\begin{array}{l}\text { Alvará de } 28 \text { de maio de } \\
1808\end{array}$ & RJ, BA & 400 réis por arroba importado por mar e terra. \\
\hline $\begin{array}{l}\text { Imposto sobre a } \\
\text { Aguardente } \\
\text { Cachaça }\end{array}$ & $\begin{array}{l}\text { Provisão do Tesouro de } \\
30 \text { de agosto de } 1802\end{array}$ & $\mathrm{CE}$ & $6 \$ 000$ réis por Pipa. \\
\hline $\begin{array}{l}\text { Meio real em libra } \\
\text { de Carne Verde }\end{array}$ & $\begin{array}{l}\text { Ordem de } 11 \text { de junho } \\
\text { de } 1751\end{array}$ & PA & A quota é a denominação da renda. \\
\hline Pau Brasil & $\begin{array}{l}\text { Regimento de } 12 \text { de } \\
\text { dezembro de } 1605\end{array}$ & $\begin{array}{l}\text { BA, AL, PE, } \\
\quad \text { PB, RN }\end{array}$ & - \\
\hline $\begin{array}{l}\text { Produto da Venda } \\
\text { da Pólvora / Propina } \\
\text { da Pólvora }\end{array}$ & $\begin{array}{l}\text { Provisão do Conselho } \\
\text { Ultramarino de } 28 \text { de } \\
\text { outubro de } 1681 \text { (PE); } \\
\text { Carta Regia de } 18 \text { de } \\
\text { março de } 1801 \text { (AL); } \\
\text { Alvará de } 21 \text { de abril de } \\
1801 \text { (PA); Aviso de } \\
\text { Guerra de 26 de julho de } \\
1808 \text { (MA / PA); Aviso } \\
\text { de } 16 \text { de janeiro de } 1810 \\
\text { (MG) }\end{array}$ & $\begin{array}{l}\mathrm{AL}, \mathrm{PE}, \mathrm{MA}, \\
\mathrm{PA}, \mathrm{MG}\end{array}$ & $\begin{array}{l}\text { MA - Neste rendimento se compreende o valor da pólvora, e } \\
\text { concede-se } 8,5 \% \text { da venda; } \mathrm{MG} \text { - Consiste na venda da dita a } \\
320 \text { réis a libra da fina e } 300 \text { réis da grossa, comprada a } \\
\text { particulares. }\end{array}$ \\
\hline
\end{tabular}




\begin{tabular}{|c|c|c|c|}
\hline $\begin{array}{l}\text { Quinto do Couro e } \\
\text { Gado em Pé }\end{array}$ & Estabelecido em 1738 & RS & $\begin{array}{l}1 \text { de } 5 \text { couros; e do gado em pé, exportado para São Paulo e } \\
\text { Santa Catarina, } 240 \text { réis por cabeça. }\end{array}$ \\
\hline Redízima do Sal & Estabelecido em 1534 & PE & - \\
\hline $\begin{array}{ll}\text { Subsídio } & \text { da } \\
\text { Aguardente } & \text { da } \\
\text { Terra; e Vinhos de } \\
\text { Mel / Subsídio } & \text { da } \\
\text { Aguardente } & \text { da } \\
\text { Terra (PE) } & \\
\end{array}$ & $\begin{array}{l}\text { Carta Regia de } 24 \text { de } \\
\text { novembro de } 1695 \\
\text { Carta Regia de } 04 \text { de } \\
\text { novembro de } 1709\end{array}$ & BA, PE & $\begin{array}{l}\text { BA - } 40 \$ \text { réis por alambique de um só cano; } 60 \$ \text { réis por dito } \\
\text { de dois; e } 1 \$ \text { réis por Pipa de entrada; PE - } 1 \$ 600 \text { réis por Pipa } \\
\text { exportada. }\end{array}$ \\
\hline $\begin{array}{l}\text { Subsídio de } 80 \text { réis } \\
\text { em Canada de } \\
\text { Aguardente }\end{array}$ & $\begin{array}{l}\text { Carta Regia de } 27 \text { de } \\
\text { maio de } 1757\end{array}$ & BA & A quota é a mesma da denominação da renda. \\
\hline Subsídio do Açúcar & $\begin{array}{l}\text { Estabelecido em } 1630 \\
(\mathrm{AL}) ; \text { Ordem de } 17 \text { de } \\
\text { setembro de } 1731 \text { (PB); } \\
\text { Carta Regia de } 19 \text { de } \\
\text { maio de } 1799\end{array}$ & $\begin{array}{l}\mathrm{BA}, \mathrm{AL}, \mathrm{PE}, \\
\mathrm{PB}\end{array}$ & 60 réis por arroba de açúcar; e 30 réis por dita mascavo. \\
\hline Subsídio do Tabaco & $\begin{array}{l}\text { Carta Regia de } 19 \text { de } \\
\text { maio de } 1799\end{array}$ & BA & 40 réis por arroba de tabaco; e 20 réis por dito refogado. \\
\hline Subsídio Literário & $\begin{array}{l}\text { Lei de } 10 \text { de novembro } \\
\text { de } 1772 ; \text { Carta Regia de } \\
23 \text { de agosto de } 1805\end{array}$ & $\begin{array}{c}\text { RJ, ES, BA, } \\
\text { SE, AL, PE, } \\
\text { PB, RN, CE, } \\
\text { PI, MA, PA, } \\
\text { SP, SC, RS, } \\
\text { MG, GO, MT }\end{array}$ & $\begin{array}{l}3 \$ 600 \text { réis por pipa de aguardente da terra; e } 320 \text { réis por cada } \\
\text { rês que se corta. }\end{array}$ \\
\hline Tintena do Peixe & $\begin{array}{l}\text { Carta Regia de } 14 \text { de } \\
\text { novembro de } 1634\end{array}$ & $\mathrm{PE}$ & Consiste em 1 por 20. \\
\hline
\end{tabular}

Fonte: (Relatório do Ministério da Fazenda, 1828)

A seguir serão apresentados os tributos incidentes sobre a passagem e entrada de pessoas, animais, escravos e mercadorias entre as Províncias. Em suma, a circulação interna existente no Império do Brasil. Por meio do Quadro 30 é possível constatar que havia o recolhimento fiscal das entradas somente nas Províncias que promoveram a atividade mineratória: Minas Gerais, Goiás e Mato Grosso. A relação abaixo é constituída por 10 fontes de receita:

Quadro 30 - Relacão dos Tributos Incidentes sobre Passagens e Registros, (1828)

\begin{tabular}{|c|c|c|c|}
\hline Tributo & Lei da sua fundação & Província & Quotização (\%, moeda corrente e/ou base de incidência) \\
\hline $\begin{array}{l}\text { Contribuição de } 80 \text { réis } \\
\text { por Cabeça de Gado }\end{array}$ & $\begin{array}{l}\text { Portaria de } \quad 18 \text { de } \\
\text { novembro de } 1801\end{array}$ & SP & $\begin{array}{l}80 \text { réis por cada cabeça de gado vacum que passe pela Vila de } \\
\text { Lorena. }\end{array}$ \\
\hline $\begin{array}{l}\text { Contribuição } \\
\text { Voluntária para a } \\
\text { Fatura da Estrada de } \\
\text { Santos }\end{array}$ & $\begin{array}{l}\text { Aviso da Marinha de } \\
04 \text { de novembro de } \\
1799 \text { e reduzida pela } \\
\text { Lei de } 20 \text { de setembro } \\
\text { de } 1828\end{array}$ & SP & $\begin{array}{l}\text { Percebe-se o seguinte: } 120 \text { réis por animal de transporte; } 120 \\
\text { réis por porco; } 240 \text { réis em rês que descer ou subir a Serra } \\
\text { pela estrada referida. }\end{array}$ \\
\hline 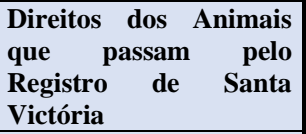 & $\begin{array}{l}\text { Portaria de } 25 \text { de } \\
\text { outubro de } 1739\end{array}$ & RS & $\begin{array}{l}\text { Neste Registro se arrecada o mesmo que nos demais, como se } \\
\text { diz no Art. - Dízimos - porém, as bestas muares espanholas } \\
\text { pagam } 2 \$ 000 \text { réis, e as da Província } 1 \$ 000 \text { réis. }\end{array}$ \\
\hline $\begin{array}{l}\text { Direitos dos Escravos } \\
\text { que vão para as Terras } \\
\text { Minerais }\end{array}$ & $\begin{array}{l}\text { Ordem do Conselho } \\
\text { Ultramarino de } 27 \text { de } \\
\text { março de } 1714\end{array}$ & $\mathrm{RJ}$ & $\begin{array}{l}4 \$ 500 \text { réis por escravo que passa pela primeira vez para terras } \\
\text { minerais. }\end{array}$ \\
\hline
\end{tabular}




\begin{tabular}{|c|c|c|c|}
\hline $\begin{array}{l}\text { Emolumentos de } \\
\text { Ofícios de Diversas } \\
\text { Repartições }\end{array}$ & $\begin{array}{l}\text { Decreto de } 12 \text { de } \\
\text { novembro de } 1822\end{array}$ & RJ & $\begin{array}{l}\text { Ao governador de Santa Cruz } 3 \$ 310 \text { réis sendo navio que sai } \\
\text { pela Barra } 1 \$ 970 \text { réis por Bergantim, - } 1 \$ 490 \text { réis por Sumaca } \\
-430 \text { réis por lancha. Ao governador da Ilha das Cobras - } \\
1 \$ 320 \text { réis por navio, } 660 \text { réis por Bergantim - } 430 \text { réis por } \\
\text { Sumaca. Ao secretário do governo das Armas, pertence uma } \\
\text { dedução dos Emolumentos mencionados para o governador } \\
\text { de Santa Cruz, declarados na relação inserta no Alvará de } 03 \\
\text { de junho de } 1810 \text { e dos Ofícios do Escrivão da Balança, } \\
\text { Porteiro e Meirinho da Alfândega não consta. }\end{array}$ \\
\hline \begin{tabular}{|l|} 
Emolumentos dos \\
Viajantes que vão para \\
Terras Minerais \\
\end{tabular} & $\begin{array}{l}\text { Provisão do Conselho } \\
\text { Ultramarino de } 24 \text { de } \\
\text { fevereiro de } 1680\end{array}$ & RJ & 240 réis que paga a pessoa que transita para terra minerais. \\
\hline Entradas & $\begin{array}{l}\text { Carta Regia de } 09 \text { de } \\
\text { novembro de } 1709 ; \text { e } \\
24 \text { de julho de } 1711 ; \\
\text { Estabelecido em } 1795 \\
\text { (GO); Estabelecido no } \\
\text { ano de } 1775 \text { e regulado } \\
\text { pela Provisão de } 09 \text { de } \\
\text { agosto de } 1826 \text { (MT) }\end{array}$ & MG, GO, MT & $\begin{array}{l}\text { MG - Por arroba de gênero seco que entra na Província, } 1 \$ 125 \\
\text { réis; por carga de gêneros molhados pesando } 2 \text { arrobas, } 750 \\
\text { réis; por escravo pela primeira vez, } 3 \$ 000 \text { réis; por besta ou } \\
\text { cavalo idem, } 3 \$ 000 \text { réis; por cabeça de gado, } 1 \$ 500 \text { réis. N.B } \\
\text { - o Direito do gado foi extinto por Provisão do Tesouro de } 02 \\
\text { de setembro de } 1808 ; \text { o do sal pelo Decreto de } 29 \text { de abril de } \\
1821 ; \text { GO - Consiste no seguinte: por arroba de fazenda seca } \\
\text { e drogas de botica, } 1 \$ 125 \text { réis; } 1 / 2 \text { carga de uma besta de } \\
\text { molhados, } 750 \text { réis; escravo novo, } 3 \$ 000 \text { réis; de cada besta } \\
\text { solta, } 3 \$ 000 \text { réis; MT - Vide Goiás e Minas. }\end{array}$ \\
\hline $\begin{array}{l}\text { Meios Direitos de } \\
\text { Animais } \quad \text { Denominados } \\
\text { Casa Doada }\end{array}$ & $\begin{array}{l}\text { Pertenciam a Thomé } \\
\text { Joaquim, por Alvará de } \\
18 \text { de fevereiro de } \\
1760 \text {; reverteram para } \\
\text { a massa Geral das } \\
\text { Rendas por Provisão } \\
\text { de } 05 \text { de setembro de } \\
1808\end{array}$ & SP & $\begin{array}{l}\text { As cotas são as que constam do artigo retro Meios Direitos e } \\
\text { Direitos inteiros de Animais, com o único aumento de } 240 \\
\text { réis por cada besta muar. }\end{array}$ \\
\hline $\begin{array}{llr}\text { Meios } & \text { Direitos } & \text { e } \\
\text { Direitos } & \text { Inteiros } & \text { de } \\
\text { Animais } & & \end{array}$ & $\begin{array}{l}\text { Portaria de } 16 \text { de } \\
\text { outubro de } 1805\end{array}$ & SP & $\begin{array}{l}\text { Consiste na Entrada dos animais que vem do Sul pelo } \\
\text { Registro de Curitiba, a saber: } 1 / 2 \text { direitos } 1 \$ 250 \text { réis por besta } \\
\text { muar ou burro; } 1 \$ 000 \text { réis por cavalo e } \$ 480 \text { réis por égua, } \\
\text { que produzem as fazendas de São Pedro até a Serra do } \\
\text { Viamão e entram no dito Registro. Direitos inteiros sendo os } \\
\text { ditos animais produzidos nesta Província até o mesmo } \\
\text { Registro. }\end{array}$ \\
\hline $\begin{array}{l}\text { Passagens de Rios e } \\
\text { Registros / Passagens } \\
\text { das Barras e Rios (AL) }\end{array}$ & $\begin{array}{l}\text { Ord. do Livro } 2^{\circ} \text {, Título } \\
\text { 26, §8; Instituída pelos } \\
\text { extintos Donatários } \\
\text { (AL / PE); Carta Regia } \\
\text { de } 14 \text { de novembro de } \\
1654 \text { (PE); Carta Regia } \\
\text { de } 29 \text { de abril de } 1711 \\
\text { (MG); Portaria da } \\
\text { Junta de } 1810 \text { (PB) }\end{array}$ & $\begin{array}{c}\text { RJ, ES, BA, } \\
\text { AL, PE, PB, } \\
\text { RN, PI, SP, } \\
\text { SC, RS, MG, } \\
\text { GO, MT }\end{array}$ & 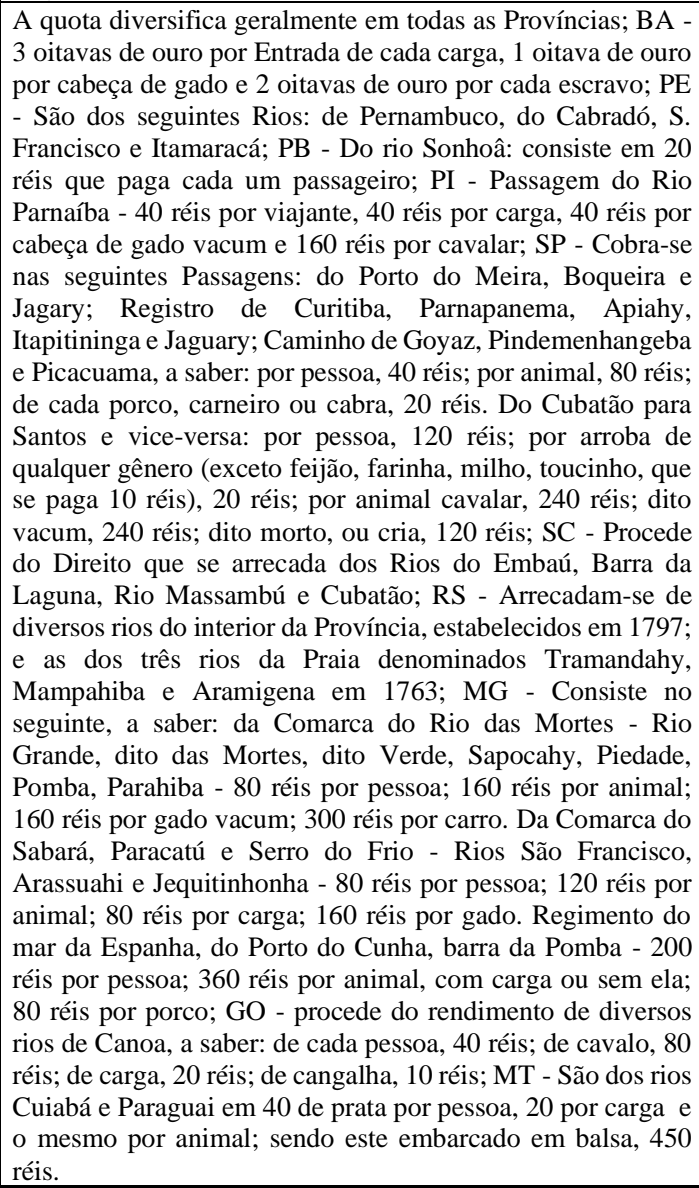 \\
\hline
\end{tabular}

Fonte: (Relatório do Ministério da Fazenda, 1828) 
O Quadro 31 ilustra as 13 fontes tributárias incidentes sobre a propriedade e a renda:

Quadro 31 - Relacão dos Tributos Incidentes sobre Propriedade e Renda, (1828)

\begin{tabular}{|c|c|c|c|}
\hline Tributo & Lei da sua fundação & Província & Quotização (\%, moeda corrente e/ou base de incidência) \\
\hline $\begin{array}{l}\text { Décima dos Prédios } \\
\text { Urbanos }\end{array}$ & $\begin{array}{l}\text { Alvará de } 27 \text { de junho } \\
\text { de } 1808\end{array}$ & $\begin{array}{c}\text { RJ, ES, BA, } \\
\text { SE, AL, PE, } \\
\text { PB, RN, CE, } \\
\text { PI, MA, PA, } \\
\text { SP, SC, RS, } \\
\text { MG, GO, MT }\end{array}$ & $9 \%$ do rendimento líquido anual; e $10 \%$ dos terrenos aforados. \\
\hline $\begin{array}{l}\text { Décima ou Selo dos } \\
\text { Legados e Heranças }\end{array}$ & $\begin{array}{l}\text { Alvará de } 17 \text { de junho } \\
\text { de } 1809\end{array}$ & $\begin{array}{c}\text { RJ, ES, BA, } \\
\text { SE, AL, PE, } \\
\text { PB, RN, CE, } \\
\text { PI, MA, PA, } \\
\text { SP, SC, RS, } \\
\text { MG, GO, MT }\end{array}$ & $\begin{array}{l}10 \% \text { da Herança ou Legado líquido e a } 5^{\mathrm{a}} \text { parte do Abintestado, } \\
\text { fora do } 2^{\circ} \text { grau. }\end{array}$ \\
\hline $\begin{array}{l}\text { Direitos de Escravos } \\
\text { Denominados } \\
\text { Equivalente e Novo } \\
\text { Imposto }\end{array}$ & $\begin{array}{l}\text { Alvará de } 10 \text { de } \\
\text { janeiro de } 1757 ; \text { Carta } \\
\text { Regia de } 18 \text { de março } \\
\text { de } 1801\end{array}$ & $\mathrm{RJ}$ & $\begin{array}{l}800 \text { réis por cada escravo, } 400 \text { réis por escravo de menos de } 3 \\
\text { anos e } 800 \text { réis pelo Equivalente. }\end{array}$ \\
\hline Foros de Sesmarias & $\begin{array}{l}\text { Carta Regia de } 07 \text { de } \\
\text { dezembro de } 1697 ; \\
\text { Carta Regia de } 20 \text { de } \\
\text { janeiro de } 1699 \text { e } 28 \\
\text { de setembro de } 1700 \\
\text { (PE); Carta Regia de } \\
20 \text { de maio de } 1722 \\
(\mathrm{RN})\end{array}$ & $\begin{array}{l}\mathrm{BA}, \mathrm{AL}, \mathrm{PE}, \\
\text { RN }\end{array}$ & $\begin{array}{l}1 \$ 000 \text { réis por légua de terra defronte de Sesmaria; PE - } 6 \$ 000 \\
\text { réis de foro por cada légua de terra que se concede de Sesmaria } \\
\text { dentro do espaço de } 30 \text { léguas contadas da costa do mar; e } 4 \$ \\
\text { réis daí ao sertão. }\end{array}$ \\
\hline Foros de Terras & Ord. L. & BA, PE, SC & - \\
\hline Laudêmios & $\begin{array}{l}\text { Alvará de } 20 \text { de } \\
\text { agosto de } 1774\end{array}$ & BA, PE, SC & - \\
\hline $\begin{array}{l}\text { Meia Sisa dos } \\
\text { Escravos Ladinos }\end{array}$ & $\begin{array}{l}\text { Alvará de } 03 \text { de junho } \\
\text { de } 1809\end{array}$ & $\begin{array}{c}\text { RJ, ES, BA, } \\
\text { SE, AL, PE, } \\
\text { PB, RN, CE, } \\
\text { PI, MA, PA, } \\
\text { SP, SC, RS, } \\
\text { MG, GO, MT }\end{array}$ & $5 \%$ deduzidos das compras e vendas dos escravos ladinos. \\
\hline $\begin{array}{l}\text { Meio Soldo das } \\
\text { Patentes Militares }\end{array}$ & $\begin{array}{l}\text { Decreto de } 16 \text { de maio } \\
\text { de } 1821\end{array}$ & $\mathrm{RJ}, \mathrm{SC}, \mathrm{MT}$ & $\begin{array}{l}\text { RJ - Metade do soldo mensal das patentes, conforme a tabela } \\
\text { inserta ao Decreto de } 28 \text { de março de } 1825 \text {. }\end{array}$ \\
\hline $\begin{array}{l}\text { Mestrado e } \\
\text { Habilitações das } \\
\text { Ordens Militares }\end{array}$ & $\begin{array}{l}\text { Alvará de } 02 \text { de junho } \\
\text { de } 1774\end{array}$ & RJ & $\begin{array}{l}12 \$ 000 \text { réis de cada um habilitando na dita Ordem, e } 50 \$ 000 \\
\text { réis ao mestrado por cada profissão. }\end{array}$ \\
\hline $\begin{array}{l}\text { Pensões de } \\
\text { Engenhos }\end{array}$ & $\begin{array}{l}\text { Instituídas pelos } \\
\text { Extintos Donatários e } \\
\text { Incorporada por Carta } \\
\text { Regia de } 04 \text { de } \\
\text { novembro de } 1654\end{array}$ & ES, PE & $\begin{array}{l}\text { ES - De } 1 \$ 000 \text { réis a } 6 \$ 400 \text { réis anualmente nos Engenhos; PE } \\
\text { - Pensão que pagam os Engenhos. }\end{array}$ \\
\hline $\begin{array}{l}\text { Sisa dos Bens de } \\
\text { Raiz }\end{array}$ & $\begin{array}{l}\text { Alvará de } 03 \text { de junho } \\
\text { de } 1809\end{array}$ & $\begin{array}{c}\text { RJ, ES, BA, } \\
\text { SE, AL, PE, } \\
\text { PB, RN, CE, } \\
\text { PI, MA, PA, } \\
\text { SP, SC, RS, } \\
\text { MG, GO, MT }\end{array}$ & $10 \%$ do valor ou preço das compras e vendas dos Bens de Raiz. \\
\hline $\begin{array}{l}\text { Terças Partes dos } \\
\text { Ofícios Forenses }\end{array}$ & $\begin{array}{l}\text { Decreto de } 18 \text { de maio } \\
\text { de } 1722\end{array}$ & $\begin{array}{l}\text { RJ, ES, BA, } \\
\text { SE, AL, PE, } \\
\text { RN, CE, MA, } \\
\text { SP, RS, MG, } \\
\text { GO, MT }\end{array}$ & Terça parte da lotação de Ofícios ocupados por serventuários. \\
\hline $\begin{array}{l}\text { Três Quartos das } \\
\text { Tenças }\end{array}$ & $\begin{array}{l}\text { Alvará de } 25 \text { de } \\
\text { agosto de } 1770\end{array}$ & RJ & $\begin{array}{l}9 \$ 000 \text { réis que paga cada um Cavaleiro da Ordem Militar na } \\
\text { expedição do respectivo Padrão de Tença. }\end{array}$ \\
\hline
\end{tabular}

Fonte: (Relatório do Ministério da Fazenda, 1828) 
A seguir apresentaremos os tributos que compunham quatro bases de incidência distintas: Botequins e Tabernas; Chancelaria; Contratos; e Diamantes/Ouro e Moeda. Optamos por estabelecer esta constituição devido ao fato de cada uma destas fontes possuir entre três a cinco tributos cada. Deste modo, julgamos ser mais conveniente a concentração destas bases de incidência no Quadro 32, que é composto por 16 tributos:

\section{Quadro 32 - Relacão dos Tributos Incidentes sobre Botequins e Tabernas, Chancelaria, Contratos, Diamantes/Ouro e Moeda, (1828)}

\begin{tabular}{|c|c|c|c|}
\hline Tributo & Lei da sua fundação & Província & Quotização (\%, moeda corrente e/ou base de incidência) \\
\hline $\begin{array}{l}\text { Contribuição do } \\
\text { Arraial do Tejuco }\end{array}$ & $\begin{array}{l}\text { Instituída pelos } \\
\text { extintos } \\
\text { Governadores } \\
\text { Capitães Generais }\end{array}$ & MG & $\begin{array}{l}\text { Consiste em } 60 \$ 000 \text { réis anuais por loja e } 36 \$ 000 \text { réis por } \\
\text { taberna. }\end{array}$ \\
\hline $\begin{array}{lrr}\text { Imposto } & \text { dos } \\
\text { Botequins } & \text { e } \\
\text { Tavernas } & / & \text { Imposto } \\
\text { de 10\$ réis } & \text { por } \\
\text { Tabernas } & \text { e } \\
\text { Botequins (ES) } & \\
\end{array}$ & $\begin{array}{l}\text { Carta Regia de } 18 \text { de } \\
\text { maio de } 1801\end{array}$ & RJ, ES, RS & $\begin{array}{l}\text { RJ / RS - } 16 \$ \text { réis anuais por cada casa, onde se vende } \\
\text { aguardente da Terra dentro da cidade e } 10 \$ \text { réis nos subúrbios; } \\
\text { ES - A quota é a denominação da renda. }\end{array}$ \\
\hline Novo Imposto & $\begin{array}{l}\text { Carta Regia de } 16 \text { de } \\
\text { dezembro de } 1775\end{array}$ & SP & $\begin{array}{l}6 \$ 400 \text { réis por Tabernas e Botequins, e nas vilas marítimas } \\
\text { recai em diversos gêneros de importação e exportação, } \\
\text { conforme as Posturas das Câmaras respectivas; e no } \\
\text { Regimento de Sorocaba se percebe } 320 \text { réis por besta, } 200 \text { réis } \\
\text { por cavalo e } 100 \text { réis por cabeça de gado vacum. }\end{array}$ \\
\hline $\begin{array}{lr}\text { Direitos da } \\
\text { Chancelaria das } \\
\text { Ordens Militares }\end{array}$ & $\begin{array}{l}\text { Regimento de } 11 \text { de } \\
\text { abril de } 1661 \text { (RJ); } \\
\text { Regimento de } 12 \text { de } \\
\text { junho de } 1708\end{array}$ & RJ & - \\
\hline 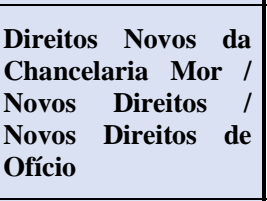 & $\begin{array}{l}\text { Alvará de } 11 \text { de abril } \\
\text { de } 1661 ; \text { Decreto de } \\
18 \text { de maio de } 1722 \\
(\mathrm{CE})\end{array}$ & $\begin{array}{c}\text { RJ, ES, BA, } \\
\text { SE, AL, PE, } \\
\text { PB, RN, CE, } \\
\text { PI, MA, PA, } \\
\text { SP, SC, RS, } \\
\text { MG, GO, MT }\end{array}$ & - \\
\hline $\begin{array}{l}\text { Direitos Velhos da } \\
\text { Chancelaria Mor }\end{array}$ & $\begin{array}{l}\text { Regimento de } 16 \text { de } \\
\text { janeiro de } 1589\end{array}$ & $\mathrm{RJ}$ & - \\
\hline $\begin{array}{ll}\text { Dízima das } \\
\text { Chancelarias }\end{array}$ & 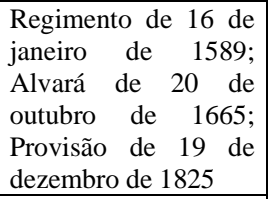 & $\begin{array}{l}\text { RJ, BA, PE, } \\
\text { MA }\end{array}$ & $\begin{array}{l}\text { RJ - } 10 \% \text { que se deduz do valor da má demanda, cuja sentença } \\
\text { passa pelas Chancelarias. }\end{array}$ \\
\hline Donativos de Ofícios & $\begin{array}{l}\text { Decreto de } 18 \text { de maio } \\
\text { de } 1722 ; \text { Decreto de } \\
18 \text { de maio de } 1822\end{array}$ & $\begin{array}{l}\text { RJ, ES, BA, } \\
\text { SE, AL, PE, } \\
\text { PB, RN, CE, } \\
\text { SP, SC, RS, } \\
\text { MG, GO, MT }\end{array}$ & $\begin{array}{l}\text { RJ - Consiste no preço total da arrematação, que se faz de } \\
\text { qualquer Ofício pelo Conselho da Fazenda. }\end{array}$ \\
\hline $\begin{array}{l}\text { Propina de } 1 \% \text { da } \\
\text { Obra Pia / Propina } \\
\text { de } 1 \% \text { dos Contratos }\end{array}$ & $\begin{array}{l}\text { Alvará de } 01 \text { de } \\
\text { agosto de } 1752\end{array}$ & $\begin{array}{l}\text { RJ, ES, BA, } \\
\text { SE, AL, PE, } \\
\text { PB, RN, CE, } \\
\text { PI, MA, PA, } \\
\text { SP, SC, GO, } \\
\text { MT } \\
\end{array}$ & A quota desta renda é a mesma da denominação. \\
\hline $\begin{array}{ll}\text { Propina } & \text { dos } \\
\text { Enjeitados } & \end{array}$ & $\begin{array}{l}\text { Carta Regia de } 08 \text { de } \\
\text { junho de } 1675\end{array}$ & $\mathrm{PE}$ & $\begin{array}{l}49760 \text { réis por ano nos Contratos; e } 50 \$ \text { réis nos dízimos } \\
\text { também por ano. }\end{array}$ \\
\hline $\begin{array}{ll}\text { Propina } & \text { dos } \\
\text { Empregados } & \end{array}$ & $\begin{array}{l}\text { Carta Regia de } 18 \text { de } \\
\text { janeiro de } 1790\end{array}$ & MA & $\begin{array}{l}2046 / 8 \text { réis incluídos na quantia de } 1.4117 / 8 \text { de cada } 100 \$ \text { réis } \\
\text { dos contratos. }\end{array}$ \\
\hline $\begin{array}{l}\text { Propina para a Casa } \\
\text { da Pólvora }\end{array}$ & $\begin{array}{l}\text { Alvará de } 3 \text { de março } \\
\text { de } 1770\end{array}$ & MA & $1 \$ 663$ réis por cada $10 \$ 000$ réis do total das arrematações. \\
\hline $\begin{array}{l}\text { Direitos de } \mathbf{5 \%} \text { do } \\
\text { Ouro }\end{array}$ & $\begin{array}{l}\text { Lei de } 26 \text { de outubro } \\
\text { de } 1827\end{array}$ & $\begin{array}{l}\text { RJ, MG, GO, } \\
\text { MT }\end{array}$ & RJ - A quota é a denominação da renda. \\
\hline
\end{tabular}




\begin{tabular}{|l|l|l|l|l|}
$\begin{array}{l}\text { Direitos do } 4^{\mathbf{0}} \text { do } \\
\text { Ouro }\end{array}$ & $\begin{array}{l}\text { Decreto de 16 de } \\
\text { setembro de 1824 }\end{array}$ & MG & $\begin{array}{l}\text { Deduzido do ouro que se extrai do Congo Soco da Companhia } \\
\text { Estrangeira. }\end{array}$ \\
\hline $\begin{array}{l}\text { Direitos Senhorial da } \\
\text { Moedagem }\end{array}$ & $\begin{array}{l}\text { Alvará de 09 de } \\
\text { setembro de 1686 (RJ } \\
\text { / BA); Lei de 04 de } \\
\text { agosto de 1688; } \\
\text { Alvará de 20 de } \\
\text { novembro de 1809 }\end{array}$ & RJ, BA & $\begin{array}{l}\text { Consiste no excedente do valor intrínseco das moedas que se } \\
\text { cunham. }\end{array}$ \\
\hline Diamantes & $\begin{array}{l}\text { Lei de 24 de } \\
\text { dezembro de 1734 }\end{array}$ & MG & \\
\hline
\end{tabular}

Fonte: (Relatório do Ministério da Fazenda, 1828)

Na sequência apresentaremos o Quadro 33. Esta relação foi estruturada tendo como critério tributos que, mesmo com a mesma nomenclatura, possuem bases de tributação diferentes, tributos que dentro da mesma classificação possuem mais de uma base de tributação, tributos que não se encaixam nas categorias acima listadas e tributos que não deixam claro qual era a sua base de tributação. No Quaro 33 observamos a existência de 24 fontes tributárias:

\section{Quadro 33 - Tributos Diversos, (1828)}

\begin{tabular}{|c|c|c|c|}
\hline Tributo & Lei da sua fundação & Província & Quotização (\%, moeda corrente e/ou base de incidência) \\
\hline $\begin{array}{l}\text { Capelas / Pensão } \\
\text { para a Capela } \\
\text { Imperial }\end{array}$ & $\begin{array}{l}\text { Alvará de } 14 \text { de janeiro de } \\
1807 ; \text { Alvará de } 20 \text { de } \\
\text { agosto de } 1808\end{array}$ & $\begin{array}{l}\text { RJ, BA, SE, } \\
\text { AL, PE, PB, } \\
\text { MA, GO }\end{array}$ & $\begin{array}{l}\text { 5\% do rendimento anual das Freguesias, deduzidos da sua } \\
\text { lotação; RJ - Instaurados pela Lei de } 15 \text { de outubro de } 1827 \\
\text { para fundo da Caixa de Amortização. }\end{array}$ \\
\hline Captivos & $\begin{array}{l}\text { Ordenação da Junta de } 02 \\
\text { de junho de } 1728 \text { (PB); Lei } \\
\text { de } 4 \text { de dezembro de } 1775 \\
\text { (PE) }\end{array}$ & PE, PB & $\begin{array}{l}\text { PB - Produto líquido do que se arremata, das coisas que } \\
\text { aparecem sem dono. }\end{array}$ \\
\hline $\begin{array}{l}\text { Contribuição de } \\
\text { Polícia }\end{array}$ & $\begin{array}{l}\text { Aviso de } 04 \text { de dezembro } \\
\text { de } 1810 \text {; Lei de } 06 \text { de } \\
\text { novembro de } 1827\end{array}$ & $\begin{array}{l}\text { RJ, BA, PE, } \\
\text { MA, PA }\end{array}$ & $\begin{array}{l}\text { BA / PE - } 800 \text { réis por escravo importado; } 600 \text { réis por dito; } \\
1 \$ 000 \text { réis por pipa de aguardente; } 4 \$ 800 \text { réis por escravo } \\
\text { exportado para os Portos do Sul do Rio de Janeiro; } 100 \text { réis por } \\
\text { Passaporte; e } 280 \text { réis por Habilitação; MA / PA - } 800 \text { réis por } \\
\text { escravo importado; } 600 \text { réis por dito. }\end{array}$ \\
\hline \begin{tabular}{lr}
\multicolumn{2}{l}{ Contribuição } \\
Municipal da \\
Cidade de & São \\
Paulo & $/$ \\
Consignação & \\
Municipal & da \\
Cidade & \\
\end{tabular} & Estabelecida em 1791 & SP & $\begin{array}{l}\text { Consiste em } 105 \$ 000 \text { réis anuais para pagar o ordenado do } \\
\text { Ouvidor de São Paulo. }\end{array}$ \\
\hline \begin{tabular}{lr}
\multicolumn{2}{l}{ Contribuição } \\
Voluntária & das \\
Câmaras & das \\
Vilas & da \\
Campanha & e \\
Baependy & \\
\end{tabular} & $\begin{array}{l}\text { Carta Regia de } 06 \text { de } \\
\text { novembro de } 1800\end{array}$ & MG & $\begin{array}{l}\text { Consiste na terça parte de seu rendimento; aplicado à compra } \\
\text { de diamantes a particulares. }\end{array}$ \\
\hline $\begin{array}{l}\text { Corporações de } \\
\text { Mão Morta }\end{array}$ & $\begin{array}{l}\text { Alvará de } 16 \text { de setembro } \\
\text { de } 1817\end{array}$ & RJ & $\begin{array}{l}\text { Instaurados pela Lei de } 15 \text { de outubro de } 1827 \text { para fundo da } \\
\text { Caixa de Amortização. }\end{array}$ \\
\hline $\begin{array}{l}\text { Direitos de } \\
\text { Guarda Costa }\end{array}$ & $\begin{array}{l}\text { Carta Regia de } 24 \text { de } \\
\text { março de } 1720\end{array}$ & RJ & - \\
\hline $\begin{array}{l}\text { Direitos } \\
\text { Correio }\end{array}$ & $\begin{array}{l}\text { Alvará de } 20 \text { de janeiro de } \\
1798\end{array}$ & $\begin{array}{l}\text { RJ, ES, BA, } \\
\text { SE, AL, PE, } \\
\text { PB, RN, CE, } \\
\text { PI, MA, PA, } \\
\text { SP, SC, RS, } \\
\text { GO, MT }\end{array}$ & $\begin{array}{l}\text { RJ - } 5 \% \text { do rendimento das Freguesias, deduzidos da sua } \\
\text { lotação. }\end{array}$ \\
\hline
\end{tabular}




\begin{tabular}{|c|c|c|c|}
\hline $\begin{array}{l}\text { Emolumentos } \\
\text { do Juiz da } \\
\text { Balança }\end{array}$ & $\begin{array}{l}\text { Decreto de } 12 \text { de } \\
\text { novembro de } 1822\end{array}$ & PE & - \\
\hline $\begin{array}{l}\text { Emolumentos } \\
\text { dos Secretários } \\
\text { das Presidências } \\
\text { / Propina do } \\
\text { Governador e } \\
\text { Secretário (BA) } \\
\end{array}$ & $\begin{array}{l}\text { Provisão do Erário de } 21 \\
\text { de maio de } 1795 \text { (BA); Lei } \\
\text { de } 20 \text { de outubro de } 1823\end{array}$ & $\begin{array}{l}\text { ES, BA, SE, } \\
\text { AL, PE, PB, } \\
\text { RN, PI, MA, } \\
\text { PA, SP, MG, } \\
\quad \text { GO, MT }\end{array}$ & É arbitrária; consta do respectivo Regimento. \\
\hline $\begin{array}{l}\text { Imposto para a } \\
\text { Caixa de } \\
\text { Amortização }\end{array}$ & $\begin{array}{l}\text { Decreto de } 26 \text { de setembro } \\
\text { de } 1828\end{array}$ & $\mathrm{RJ}$ & $\begin{array}{l}\text { Consiste em } 2 \$ 000 \text { réis por Navio ou Corveta; } 1 \$ 200 \text { réis por } \\
\text { Sumaca; } 400 \text { réis por Barco; } 200 \text { réis por escravo; } 100 \text { réis por } \\
\text { dito pequeno; } 200 \text { réis por cabeça de gado que se corta nos } \\
\text { açougues, constantes do Alvará de } 22 \text { de janeiro de } 1810 \text {. }\end{array}$ \\
\hline $\begin{array}{l}\text { Imposto para } \\
\text { Fundo Nacional } \\
\text { do Banco }^{30}\end{array}$ & $\begin{array}{l}\text { Alvará de } 20 \text { de outubro de } \\
1812\end{array}$ & $\begin{array}{c}\text { RJ, ES, BA, } \\
\text { SE, AL, PE, } \\
\text { PB, RN, CE, } \\
\text { PI, MA, PA, } \\
\text { SP, SC, RS, } \\
\text { MG, GO, MT }\end{array}$ & 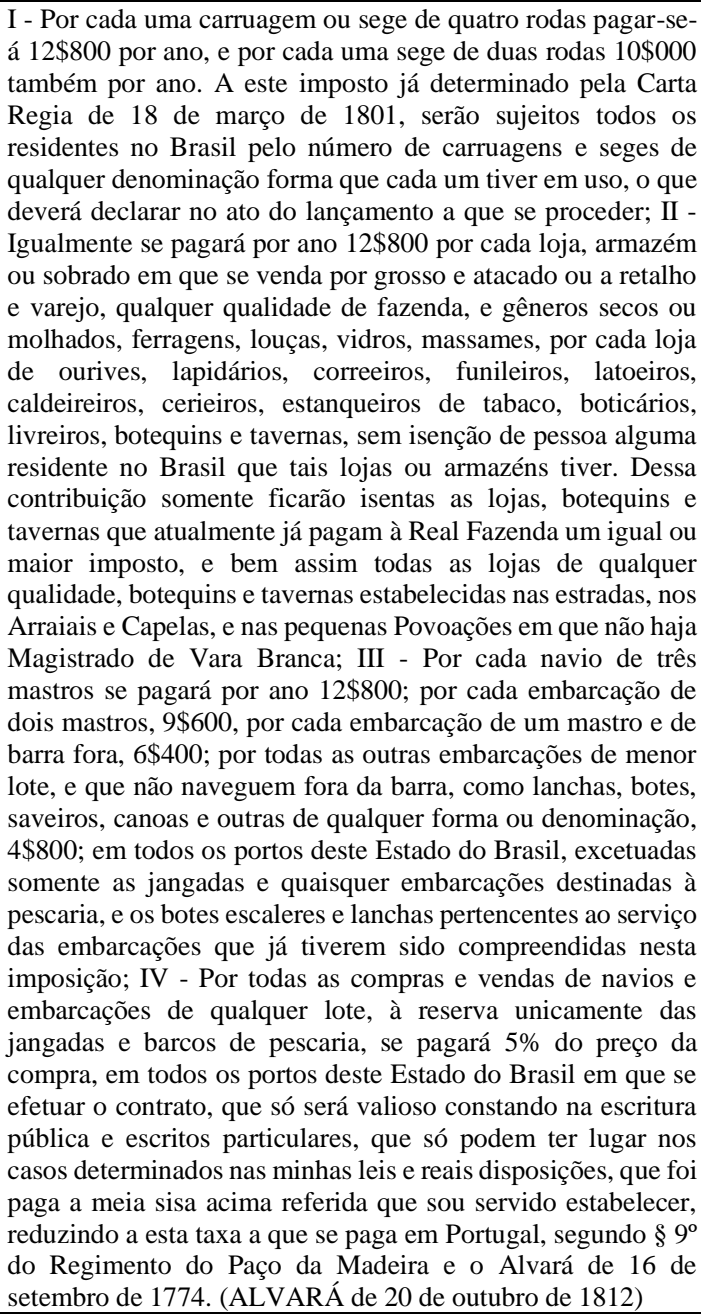 \\
\hline $\begin{array}{l}\text { Joias do } \\
\text { Cruzeiro }\end{array}$ & $\begin{array}{l}\text { Decreto de } 01 \text { de } \\
\text { dezembro de } 1822\end{array}$ & RJ & $\begin{array}{l}\text { É a obrigação que tem todos os agraciados de darem uma joia } \\
\text { para manutenção da Caixa de Piedade. }\end{array}$ \\
\hline $\begin{array}{l}\text { Madeiras de } \\
\text { Construção } \\
\text { Naval }\end{array}$ & Consta pela Marinha & AL & - \\
\hline $\begin{array}{l}\text { Multas da } \\
\text { Conservatória } \\
\text { das Matas }\end{array}$ & $\begin{array}{l}\text { Carta Regia de } 11 \text { de junho } \\
\text { de } 1799\end{array}$ & AL & - \\
\hline $\begin{array}{l}\text { Propina dos } \\
\text { Empregados de } \\
\text { Fazenda (RJ) / } \\
\text { Propina de } 3 \%\end{array}$ & $\begin{array}{l}\text { Portaria de } 03 \text { de agosto de } \\
1685\end{array}$ & RJ, SP & RJ - A quota é arbitrária. \\
\hline
\end{tabular}

30 De acordo com o documento disponível para consulta no Relatório do Ministério da Fazenda lê-se: " $12 \$ 800$ réis anuais por cada Carruagem, Loja e Navio de 3 mastros; $10 \$ 000$ réis por cada Sege; $9 \$ 600$ réis por Navio de 2 mastros; $6 \$ 400$ réis por Barco de 1 mastro de Barra fora; $4 \$ 800$ réis pelos de menor lote idem, e $5 \%$ nas compras e vendas das embarcações". Deste modo, optamos por reproduzir as informações disponíveis no Alvará de 20 de outubro de 1812. 


\begin{tabular}{|c|c|c|c|}
\hline $\begin{array}{lr}\text { para os } \\
\text { Empregados da } \\
\text { Fazenda (SP) }\end{array}$ & & & \\
\hline \begin{tabular}{ll|} 
Propina dos \\
Expostos
\end{tabular} & $\begin{array}{l}\text { Alvará de } 08 \text { de outubro de } \\
1778\end{array}$ & $\mathrm{RJ}$ & A quota é arbitrária. \\
\hline $\begin{array}{lr}\text { Propina } & \text { para } \\
\text { Munição } & \text { de } \\
\text { Guerra } & / \\
\text { Propina de } & 4 \% \\
\text { para a Munição } \\
\text { de Guerra } \\
\text { SPE) }\end{array}$ & $\begin{array}{l}\text { Ordem de } 27 \text { de outubro } \\
\text { de } 1681 \text {; Carta Regia de } 13 \\
\text { de agosto de } 1687 \text { (PE / } \\
\text { RN) }\end{array}$ & $\begin{array}{l}\text { RJ, ES, BA, } \\
\mathrm{PE}, \mathrm{PB}, \mathrm{RN} \\
\quad \mathrm{SP}\end{array}$ & $\begin{array}{l}\text { RJ - A quota é arbitrária, ou igual à que percebia o Presidente } \\
\text { da Junta; ES - 1\%; BA - Igual à que se arbitra ao Governador } \\
\text { e Empregados da Fazenda; PE - A quota é a denominação na } \\
\text { renda. }\end{array}$ \\
\hline $\begin{array}{l}\text { Próprios } \\
\text { Nacionais }\end{array}$ & $\begin{array}{l}\text { Estabelecidos por diversas } \\
\text { ordens; Ordenação da } \\
\text { Junta (PB); Alvará de } 25 \\
\text { de fevereiro de } 1761 \text { (PI); } \\
\text { Alvará de } 14 \text { de janeiro de } \\
1807 \text { (MA) }\end{array}$ & $\begin{array}{l}\text { RJ, ES, BA, } \\
\text { PE, PB, PI, } \\
\text { MA; PA, SC, } \\
\text { RS, GO, MT }\end{array}$ & $\begin{array}{l}\text { RJ - Consiste no arrendamento de } 114 \text { Barracas; rendimento } \\
\text { de } 576 \text { ações no Banco e Foros de Marinha; ES - Procede de } \\
\text { Fóros de Terras; PB - } 30 \text { réis que pagam por dia os marchantes } \\
\text { do rendimento do Cepo dos açougues; PI - Procede do redito } \\
\text { das fazendas do Canindé, Piauí e Nazaré; MA - Rendimento } \\
\text { da fazenda de N. S. de Nazaré, a de pastos bons, e as } \\
\text { denominadas S. Bernardo, e da Tipografia Nacional; PA - } \\
\text { Rendimento do pesqueiro da Ilha Joannes, (Provisão de } 12 \text { de } \\
\text { março de } 1691 \text { ); Dita da Vila Franca, (Provisão de } 12 \text { de julho } \\
\text { de } 1783 \text { ); das fazendas de Arary e S. Lourenço, (Aviso da } \\
\text { Marinha de } 24 \text { de março de } 1794 \text { ); do Cacoal de Vila Franca, } \\
\text { (Carta Regia de } 12 \text { de maio de } 1798 \text { ); da fazenda de S. Antonio } \\
\text { de Chaves, (Provisão de } 17 \text { de agosto de } 1806 \text { ); da Serraria de } \\
\text { Monte Alegre, (Portaria de } 27 \text { de junho de 1799); do Viveiro } \\
\text { de Especiaria, (Carta Regia de } 6 \text { de junho de } 1809 \text { ); RS - } \\
\text { Procede do rendimento do rincão do Rio Pardo, do Saican, do } \\
\text { Assougue, que foi dos povos Guaranis, e do Potreiro sito } \\
\text { aquém de Azenha; MT - Reditos das fazendas de gado vacum } \\
\text { e cavalar da Caisara, Miranda e Casalvasco, de onde se tiram } \\
\text { anualmente certas porções para pagamento das dívidas } \\
\text { atrasadas; e fornecimento dos hospitais e tropas; e da renda de } \\
\text { uma olaria. }\end{array}$ \\
\hline $\begin{array}{l}\text { Selo das Mercês } \\
\text { ou Imperial }\end{array}$ & $\begin{array}{l}\text { Alvará de } 27 \text { de abril de } \\
\text { 1802; e Decreto de } 24 \text { de } \\
\text { janeiro de } 1804\end{array}$ & RJ & - \\
\hline $\begin{array}{l}\text { Selo ou Taxa do } \\
\text { Papel }\end{array}$ & $\begin{array}{l}\text { Alvará de } 17 \text { de junho de } \\
1809\end{array}$ & $\begin{array}{l}\text { RJ, ES, BA, } \\
\text { SE, AL, PE, } \\
\text { PB, RN, CE, } \\
\text { PI, MA, PA, } \\
\text { SP, SC, RS, } \\
\text { MG, GO, MT }\end{array}$ & - \\
\hline $\begin{array}{l}\text { Subsídio } \\
\text { Nacional }\end{array}$ & $\begin{array}{l}\text { Carta Regia de } 31 \text { de } \\
\text { março de } 1693\end{array}$ & PI, MA & $\begin{array}{l}\text { MA - } 100 \text { réis por cada atanado que se exporta; } 50 \text { réis em } \\
\text { couro; } 50 \text { réis em sola; } 50 \text { réis em canada de aguardente } \\
\text { denominada Gerebita; } 3 \$ 000 \text { réis por Engenho de molinete; } \\
1 \$ 000 \text { réis por escravo que se arremata em hasta pública; } 1 \$ \\
\text { réis em libra de carne verde; } 200 \text { réis em rolo de pano; além de } \\
100 \text { réis mais se for embarcado para fora da cidade. }\end{array}$ \\
\hline $\begin{array}{l}\text { Subsídio } \\
\text { Voluntário }\end{array}$ & $\begin{array}{l}\text { Carta Regia de } 23 \text { de } \\
\text { outubro de } 1646 \text { (ES); } \\
\text { Carta Regia de } 16 \text { de } \\
\text { dezembro de } 1775(\mathrm{MG}) ; \\
\text { Aviso de } 24 \text { de abril de } \\
1795 \text { (MT) }\end{array}$ & ES, MG, MT & $\begin{array}{l}\text { ES - } 8 \$ \text { réis em Pipa de aguardente estrangeira; } 4 \$ \text { réis de } \\
\text { Vinho; } 80 \text { réis em alqueire de sal por importação e por } \\
\text { exportação; } 100 \text { réis em arroba de fio de algodão; } 2 \text { réis em } \\
\text { vara de pano de algodão; } 20 \text { réis em arroba de açúcar; } 40 \text { réis } \\
\text { em cada rolo de algodão; MG - } 4 \$ 800 \text { réis por escravo que } \\
\text { entra pela primeira vez na Província; } 2 \$ 400 \text { réis por besta } \\
\text { idem; } 1 \$ 200 \text { réis por cavalo idem; } 300 \text { réis por barril de vinho; } \\
\text { MT - Consiste na sexta parte da renda das Entradas das } \\
\text { mercadorias importadas nesta Província. }\end{array}$ \\
\hline $\begin{array}{l}\text { Terças Partes } \\
\text { das Câmaras }\end{array}$ & $\begin{array}{l}\text { Lei de } 22 \text { de dezembro de } \\
1761 \text { e } 11 \text { de outubro de } \\
1766 ; \text { Carta Regia de } 02 \text { de } \\
\text { novembro de } 1787\end{array}$ & PA & $\begin{array}{l}\text { Prestações que diversas Câmaras colocam anualmente para as } \\
\text { despesas públicas. }\end{array}$ \\
\hline
\end{tabular}

Fonte: (Relatório do Ministério da Fazenda, 1828)

Finda a apresentação e classificação das 125 fontes tributárias existente no Brasil no ano de 1828, é possível constatar que a maior parte dos tributos incidia sobre a produção, venda, consumo e circulação - interna e externa - de mercadorias e escravos. Deste modo, por mais que neste período tenha ocorrido a preocupação em criar impostos incidentes 
sobre a propriedade e a renda, a predominância tributária ainda seguia o modelo instaurado no Brasil Colônia.

Contudo, os Quadros 28, 29, 30, 31, 32 e 33 nada podem afirmar acerca da representatividade financeira de cada uma das rendas tributárias. Por intermédio deles foi possível analisar a estrutura tributária do país existente em fins da década de 1820, mas eles não esclarecem sobre a capacidade que cada uma das fontes fiscais possuía na arrecadação de recursos.

A fim de preenchermos esta lacuna, apresentaremos a seguir o balanço da Província de São Paulo para o ano de 1827. Por intermédio desta informação procuramos compreender a relevância fiscal de cada uma das rendas existentes na Província paulista no dito ano. A escolha pelo ano de 1827 ocorreu devido ao fato de não localizarmos nos Relatórios do Ministério da Fazenda o balanço para o ano de 1828. Ademais, procuramos fazer o levantamento do documento mais próximo possível do ano de 1828 - ano base dos Quadros sumarizados acima.

Além disso, necessitamos esclarecer quanto a escolha pela Província de São Paulo. De acordo com os dados apresentados no decorrer desta pesquisa, o Estado de São Paulo se caracteriza no século XXI como o maior arrecadador de recursos fiscais do Brasil, por intermédio do ICMS. No ano de 1827 a dita Província ainda não figurava entre as mais ilustres “joias do Tesouro" brasileiro, como veremos adiante por meio da apresentação dos orçamentos de todas as Províncias para o ano de 1830. Foi no decorrer do Segundo Reinado que São Paulo construiu e estruturou o posto de Província mais rica do país. Deste modo, tirar uma "radiografia" da Província antes deste processo é fundamental para que possamos compreender as transformações ocorridas nas décadas seguintes, bem como entender de que maneira a fiscalidade foi influenciada pela estrutura até então vigente e se delineou a partir deste momento.

Como já afirmado, o Quadro 34 foi elaborado de acordo com as informações disponíveis no balanço da Província de São Paulo do ano de 1827. Ademais, procuramos organizar as fontes tributárias levando em consideração a capacidade arrecadatória dos tributos a fim de entendermos quais eram as principais fontes de receita fiscal. Contudo, precisamos alertar o leitor que alguns tributos listados no balanço não estão relacionados nos Quadros acima apresentados. Também há casos nos quais alguns dos impostos elencados acima 
não constarem no balanço de São Paulo. Nestas situações, optamos por manter a nomenclatura tributária e não atribuir valores na coluna Arrecadado em 1827.

\section{Quadro 34 - Receita da Província de São Paulo, (1827)}

\begin{tabular}{|c|c|c|c|}
\hline Tributo & $\begin{array}{l}\text { Lei da sua } \\
\text { fundação }\end{array}$ & Quotização (\%, moeda corrente e/ou base de incidência) & $\begin{array}{c}\text { Arrecadado } \\
\text { em } 1827\end{array}$ \\
\hline $\begin{array}{l}\text { Dízimos / Dízimos de } \\
\text { Miunças, do Açúcar, } \\
\text { Café e Gado }\end{array}$ & $\begin{array}{l}\text { Carta Regia de } 18 \\
\text { de março de } 1715\end{array}$ & - & $78: 689 \$ 599$ \\
\hline $\begin{array}{llr}\text { Contribuição } & \\
\text { Literária } & & \text { da } \\
\text { Marinha } & \text { e } & \text { Portos } \\
\text { Secos } & & \end{array}$ & $\begin{array}{l}\text { Aviso de } 20 \text { de } \\
\text { julho de } 1801\end{array}$ & $\begin{array}{l}\text { Açúcar, arroba - } 40 \text { réis; Café - } 80 \text { réis; Fumo - } 80 \text { réis; } \\
\text { Toucinho e Banha - } 40 \text { réis; Goma - } 50 \text { réis; Dita por alqueire } \\
\text { - } 100 \text { réis; Algodão em rama, arroba - } 80 \text { réis; Dito em pano, } \\
\text { vara - } 3 \text { réis; Arroz pilado - } 20 \text { réis; Dito em casca, alqueire } \\
\text { - } 20 \text { réis; Dito sem casca, dito - } 40 \text { réis; Feijão, dito - } 30 \text { réis; } \\
\text { Milho, dito - } 10 \text { réis; Congonha, dita - } 80 \text { réis; } 240 \text { réis por } \\
\text { cabeça de gado e porco exportado para o Rio de Janeiro, e } \\
\text { que não tenha pago o Novo Imposto em Sorocaba. } \\
\text { Semelhantemente, } 160 \text { réis por cada potro ou besta; e sendo } \\
\text { para outras Províncias cada potro } 200 \text { réis e cada besta } 320 \\
\text { réis. }\end{array}$ & $69: 926 \$ 705$ \\
\hline $\begin{array}{l}\text { Produto das } \\
\text { Chapinhas de Cobre } \\
\text { Cunhadas }\end{array}$ & - & 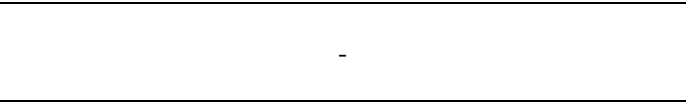 & $42: 745 \$ 880$ \\
\hline Passagens dos Rios & Ord. do Livro $2^{\circ}$ & $\begin{array}{l}\text { Cobra-se nas seguintes Passagens: do Porto do Meira, } \\
\text { Boqueira e Jagary; Registro de Curitiba, Parnapanema, } \\
\text { Apiahy, Itapetininga e Jaguary; Caminho de Goiás, } \\
\text { Pindamonhangaba e Picacuama, a saber: por pessoa, } 40 \text { réis; } \\
\text { por animal, } 80 \text { réis; de cada porco, carneiro ou cabra, } 20 \text { réis. } \\
\text { Do Cubatão para Santos e vice-versa: por pessoa, } 120 \text { réis; } \\
\text { por arroba de qualquer gênero (exceto feijão, farinha, milho, } \\
\text { toucinho, que se paga } 10 \text { réis), } 20 \text { réis; por animal cavalar, } \\
240 \text { réis; dito vacum, } 240 \text { réis; dito morto, ou cria, } 120 \text { réis. }\end{array}$ & $24: 058 \$ 187$ \\
\hline $\begin{array}{l}\text { Meios Direitos de } \\
\text { Animais } \\
\text { Denominados Casa } \\
\text { Doada }\end{array}$ & $\begin{array}{l}\text { Pertenciam a } \\
\text { Thomé Joaquim, } \\
\text { por Alvará de } 18 \text { de } \\
\text { fevereiro de } 1760 ; \\
\text { e reverteram para a } \\
\text { massa Geral das } \\
\text { Rendas por } \\
\text { Provisão de } 05 \text { de } \\
\text { setembro de } 1808 \\
\end{array}$ & $\begin{array}{l}\text { As cotas são as que constam do artigo retro Meios Direitos } \\
\text { e Direitos inteiros de Animais, com o único aumento de } 240 \\
\text { réis por cada besta muar. }\end{array}$ & $22: 208 \$ 290$ \\
\hline Alfândega de Santos & - & - & $21: 829 \$ 142$ \\
\hline Sisa dos Bens de Raiz & $\begin{array}{l}\text { Alvará de } 03 \text { de } \\
\text { junho de } 1809\end{array}$ & $\begin{array}{l}10 \% \text { do valor ou preço das compras e vendas dos Bens de } \\
\text { Raiz }\end{array}$ & $20: 125 \$ 562$ \\
\hline $\begin{array}{llr}\text { Meios Direitos e } \\
\text { Direitos Inteiros de } \\
\text { Animais }\end{array}$ & $\begin{array}{l}\text { Portaria de } 16 \text { de } \\
\text { outubro de } 1805\end{array}$ & $\begin{array}{l}\text { Consiste na Entrada dos animais que vem do Sul pelo } \\
\text { Registro de Curitiba, a saber: } 1 / 2 \text { direitos - } 1 \$ 250 \text { réis por } \\
\text { besta muar ou burro; } 1 \$ 000 \text { réis por cavalo e } \$ 480 \text { réis por } \\
\text { égua, que produzem as fazendas de São Pedro até a Serra do } \\
\text { Viamão e entram no dito Registro. Direitos inteiros sendo os } \\
\text { ditos animais produzidos nesta Província até o mesmo } \\
\text { Registro. }\end{array}$ & $20: 066 \$ 180$ \\
\hline Novo Imposto & $\begin{array}{l}\text { Carta Regia de } 16 \\
\text { de dezembro de } \\
1775\end{array}$ & $\begin{array}{l}6 \$ 400 \text { réis por Tabernas e Botequins, e nas vilas marítimas } \\
\text { recai em diversos gêneros de importação e exportação, } \\
\text { conforme as Posturas das Câmaras respectivas; e no } \\
\text { Regimento de Sorocaba se percebe } 320 \text { réis por besta, } 200 \\
\text { réis por cavalo e } 100 \text { réis por cabeça de gado vacum. }\end{array}$ & $18: 539 \$ 981$ \\
\hline $\begin{array}{l}\text { Contribuição } \\
\text { Voluntária para a } \\
\text { Fatura da Estrada } \\
\text { de Santos e Lorena / } \\
\text { Contribuição de } 80 \\
\text { réis por Cabeça de } \\
\text { Gado }\end{array}$ & $\begin{array}{l}\text { Aviso da Marinha } \\
\text { de } 04 \text { de novembro } \\
\text { de } 1799 ; \text { e reduzida } \\
\text { pela Lei de } 20 \text { de } \\
\text { setembro de } 1828 ; \\
\text { Portaria de } 18 \text { de } \\
\text { novembro de } 1801 \\
\end{array}$ & $\begin{array}{l}\text { Percebe-se o seguinte: } 120 \text { réis por animal de transporte; } 120 \\
\text { réis por porco; } 240 \text { réis em rês que descer ou subir a Serra } \\
\text { pela estrada referida; } 80 \text { réis por cada cabeça de gado vacum } \\
\text { que passe pela Vila de Lorena. }\end{array}$ & $17: 521 \$ 414$ \\
\hline $\begin{array}{l}\text { Imposição de } 5 \text { réis } \\
\text { em libra de Carne } \\
\text { Verde / Carne Verde } \\
\text { de Vaca }\end{array}$ & $\begin{array}{l}\text { Alvará de } 03 \text { de } \\
\text { junho de } 1809\end{array}$ & - & $13: 259 \$ 068$ \\
\hline
\end{tabular}




\begin{tabular}{|c|c|c|c|}
\hline $\begin{array}{l}\text { Imposto para Fundo } \\
\text { Nacional do Banco }\end{array}$ & $\begin{array}{l}\text { Alvará de } 20 \text { de } \\
\text { outubro de } 1812\end{array}$ & Ver Quadro 33 & $10: 887 \$ 187$ \\
\hline Subsídio Literário & $\begin{array}{l}\text { Lei de } 10 \text { de } \\
\text { novembro de } 1772\end{array}$ & $\begin{array}{l}3 \$ 600 \text { réis por pipa de aguardente da terra; e } 320 \text { réis por } \\
\text { cada rês que se corta. }\end{array}$ & $9: 517 \$ 411$ \\
\hline $\begin{array}{lr}\text { Propinas / } & \text { Propina } \\
\text { de } 1 \% & \text { dos } \\
\text { Contratos; } & \text { Propina } \\
\text { de } 3 \% \text { para } & \text { os } \\
\text { Empregados } & \text { da } \\
\text { Fazenda; Propina de } \\
\text { 4\% para a Munição } \\
\text { de Guerra }\end{array}$ & - & $\begin{array}{l}\text { Deduz-se } 8 \% \text { : } 1 \% \text { para a obra pia, } 3 \% \text { para os empregados } \\
\text { da Junta e } 4 \% \text { para munição de guerra. }\end{array}$ & $8: 317 \$ 740$ \\
\hline $\begin{array}{l}\text { Selo ou Taxa do } \\
\text { Papel / Taxa do Selo } \\
\text { ou Causa Pública }\end{array}$ & $\begin{array}{l}\text { Alvará de } 17 \text { de } \\
\text { junho de } 1809\end{array}$ & - & $7: 135 \$ 510$ \\
\hline $\begin{array}{lr}\text { Contribuição } & \text { para a } \\
\text { Conquista } & \text { de } \\
\text { Garapuava } & / \\
\text { Rendimento } & \text { da } \\
\text { Contribuição } & \text { para a } \\
\text { Povoação } & \text { de } \\
\text { Guarapuaba } & \\
\end{array}$ & $\begin{array}{l}\text { Carta Regia de } 01 \\
\text { de abril de } 1809\end{array}$ & $\begin{array}{l}\text { De cada besta muar criada até a Vila de Sorocaba, } 875 \text { réis; } \\
\text { de cada cavalo, } 750 \text { réis; de cada cabeça de gado vacum, } 240 \\
\text { réis. Porém, sendo criados no Sul, Vacaria e Lages, } \\
\text { arrecada-se de cada uma } 160 \text { réis, e cada cavalo } 220 \text { réis. }\end{array}$ & $6: 148 \$ 415$ \\
\hline $\begin{array}{l}\text { Décima dos Prédios } \\
\text { Urbanos }\end{array}$ & $\begin{array}{l}\text { Alvará de } 27 \text { de } \\
\text { junho de } 1808\end{array}$ & $\begin{array}{l}9 \% \text { do rendimento líquido anual; e } 10 \% \text { dos terrenos } \\
\text { aforados. }\end{array}$ & $5: 110 \$ 307$ \\
\hline $\begin{array}{l}\text { Entradas para } \\
\text { Minas }\end{array}$ & - & - & $3: 831 \$ 726$ \\
\hline Direitos do Correio & $\begin{array}{l}\text { Alvará de } 20 \text { de } \\
\text { janeiro de } 1798\end{array}$ & - & $3: 458 \$ 490$ \\
\hline \begin{tabular}{ll|} 
Emolumentos & da \\
Secretaria & do \\
Governo & \\
\end{tabular} & $\begin{array}{l}\text { Lei de } 20 \text { de } \\
\text { outubro de } 1823\end{array}$ & Consta do respectivo Regimento. & $1: 884 \$ 720$ \\
\hline \begin{tabular}{ll|} 
Meia Sisa dos \\
Escravos Ladinos
\end{tabular} & $\begin{array}{l}\text { Alvará de } 03 \text { de } \\
\text { junho de } 1809\end{array}$ & $5 \%$ deduzidos das compras e vendas dos escravos ladinos. & $1: 523 \$ 842$ \\
\hline Donativos de Ofícios & $\begin{array}{l}\text { Decreto de } 18 \text { de } \\
\text { maio de } 1722\end{array}$ & - & $1: 460 \$ 467$ \\
\hline $\begin{array}{l}\text { Novos Direitos de } \\
\text { Ofícios }\end{array}$ & $\begin{array}{l}\text { Alvará de } 11 \text { de } \\
\text { abril de } 1661\end{array}$ & - & $488 \$ 605$ \\
\hline $\begin{array}{lr}\text { Rendimentos dos } \\
\text { Bens dos Ex Jesuítas } \\
\end{array}$ & - & - & $280 \$ 413$ \\
\hline Chancelaria & - & - & $28 \$ 070$ \\
\hline Dízima das Madeiras & $\begin{array}{l}\text { Portaria de } 5 \text { de } \\
\text { março de } 1802\end{array}$ & $\begin{array}{l}\text { Deduz-se das madeiras produzidas nas Vilas de Paranaguá e } \\
\text { Antonina. }\end{array}$ & $9 \$ 360$ \\
\hline $\begin{array}{l}\text { Décima ou Selo dos } \\
\text { Legados e Heranças }\end{array}$ & $\begin{array}{l}\text { Alvará de } 17 \text { de } \\
\text { junho de } 1809\end{array}$ & $\begin{array}{l}10 \% \text { da Herança ou Legado líquido e a } 5^{\mathrm{a}} \text { parte do } \\
\text { Abintestado, fora do } 2^{\mathrm{o}} \text { grau. }\end{array}$ & - \\
\hline $\begin{array}{l}\text { Terças partes dos } \\
\text { Ofícios }\end{array}$ & $\begin{array}{l}\text { Decreto de } 18 \text { de } \\
\text { maio de } 1722\end{array}$ & - & - \\
\hline $\begin{array}{l}\text { Direitos de } 15 \% \text { de } \\
\text { Importação }\end{array}$ & \begin{tabular}{|l} 
Lei de 24 de \\
setembro de 1828 \\
\end{tabular} & - & - \\
\hline $\begin{array}{l}\text { Direitos de } 2 \% \text { da } \\
\text { Exportação }\end{array}$ & $\begin{array}{l}\text { Alvará de } 25 \text { de } \\
\text { abril de } 1818\end{array}$ & - & - \\
\hline $\begin{array}{l}\text { Ancoragem dos } \\
\text { Navios Estrangeiros }\end{array}$ & $\begin{array}{l}\text { Decreto de } 15 \text { de } \\
\text { março de } 1810\end{array}$ & $1 \$ 000$ réis diários que pagam as embarcações estrangeiras. & - \\
\hline $\begin{array}{l}\text { Contribuição } \\
\text { Municipal da Cidade } \\
\text { de São Paulo / } \\
\text { Consignação } \\
\text { Municipal da Cidade }\end{array}$ & $\begin{array}{l}\text { Estabelecida em } \\
1791\end{array}$ & $\begin{array}{l}\text { Consiste em } 105 \$ 000 \text { réis anuais para pagar o ordenado do } \\
\text { Ouvidor de São Paulo }\end{array}$ & - \\
\hline $\begin{array}{l}\text { Rendimento } \\
\text { Extraordinário }\end{array}$ & - & - & $7: 644 \$ 603$ \\
\hline Total & - & - & 416:696\$874 $4^{31}$ \\
\hline
\end{tabular}

${ }^{31} \mathrm{O}$ documento original possui como somatório o valor de 417:000\$177. Mesmo sendo ínfima a diferença, optamos por manter o resultado total da soma correta da coluna. 
De acordo com o observado no Quadro 34, é possível concluir ser o dízimo o principal imposto da Província de São Paulo, com um montante arrecadatório de 78:689\$599, ou seja, quase $19 \%$ do total recolhido, considerando-se as rendas extraordinárias.

Acerca da metodologia de arrecadação do dízimo, essa ainda era regida pela Carta Regia de 18 de março de 1715. Tal situação perdurou até 1829, quando ocorreu a determinação em fazer-se cumprir o estabelecido no Decreto de 16 de abril de 1821:

Desde o período colonial até 1829 , o dízimo foi cobrado pelos contratantes que arrematavam a cobrança desta taxa. Neste ano determinava-se a execução do decreto de 16 de abril de 1821, que mandava cobrar nos portos de embarque o dízimo do açúcar, algodão em rama, café, arroz, trigo e fumo e que por isso não deseja contratado ou arrematado nesta Província o dízimo dos referidos gêneros, pondo-se deste modo um termo ao fraudulento e intolerável uso das guias passadas por contratadores, ficando a cobrança dos dízimos a cargo da Junta da Fazenda. (PETRONE, 1968, p. 24)

Sobre os gêneros que mais contribuíram para a arrecadação do dízimo, e outros impostos na Província de São Paulo, o açúcar se destaca. As terras paulistas eram produtoras de açúcar, sendo essa a principal mercadoria produzida e comercializada no período que nos ocupa:

O açúcar e a aguardente sempre constituíram produtos dos mais taxados no Brasil, inclusive em São Paulo. A cultura da cana-de-açúcar em São Paulo floresceu no período que vai do início do governo do Morgado de Matheus (1765) até 1851, quando a exportação de café pelo porto de Santos sobrepuja em volume a de açúcar. A população, principalmente os senhores de engenho e os comerciantes, sempre se queixaram contra as taxas que recaíam sobre a aguardente e o açúcar, encarecendo-os e diminuindo o lucro. Além das taxas ligadas às vias de comunicação, tais como as passagens, o donativo voluntário criado por Melo Castro e Mendonça para melhoramentos na estrada de Santos, o contrato real de Cubatão etc., havia outras taxas a serem pagas sobre o açúcar e a aguardente. O dízimo é, sem dúvida, o principal imposto que recaía sobre o açúcar; recaía, aliás, sobre todos os produtos da agricultura, da pecuária e da pesca do Brasil. (PETRONE, 1968, pp. 23-24)

Deste modo, assim como nas Províncias do Nordeste no Período Colonial, temos a presença do açúcar e do dízimo na Província de São Paulo em fins de 1820. Todavia, não nos enganemos, pois nesta ocasião São Paulo ainda não figurava entre as mais ricas localidades do país, estes postos eram ocupados por Rio de Janeiro, Bahia e Pernambuco, conforme demonstrado no Quadro 35: 


\section{Quadro 35 - Quadro Geral do Orcamento da Receita do Tesouro Nacional em todo o Império - $1^{\circ}$ Semestre de 1830 e Ano Financeiro de $1^{\circ}$ de julho de 1830 a 30 de junho de 1831}

\begin{tabular}{|c|c|c|c|}
\hline Província & Receita Ordinária & Receita Extraordinária & Total \\
\hline Rio de Janeiro & $8.665: 622 \$ 500$ & $3.354: 450 \$ 000$ & $12.020: 072 \$ 500$ \\
\hline Bahia & $2.756: 538 \$ 891$ & 543:861\$999 & $3.300: 400 \$ 890$ \\
\hline Pernambuco & $1.683: 543 \$ 735$ & $16: 825 \$ 168$ & $1.700: 368 \$ 903$ \\
\hline Maranhão & $949: 922 \$ 845$ & $360 \$ 000$ & $950: 282 \$ 845$ \\
\hline Rio Grande do Sul & $823: 389 \$ 982$ & $30: 086 \$ 237$ & $853: 476 \$ 219$ \\
\hline Minas Gerais & $594: 450 \$ 000$ & 27:000\$000 & $621: 450 \$ 000$ \\
\hline Pará & $509: 450 \$ 229$ & $3: 537 \$ 562$ & $512: 987 \$ 791$ \\
\hline São Paulo & $454: 554 \$ 000$ & $2: 277 \$ 000$ & $456: 831 \$ 000$ \\
\hline Alagoas & 223:908\$683 & $592 \$ 249$ & $224: 500 \$ 932$ \\
\hline Piauí & $176: 076 \$ 402$ & $300 \$ 000$ & $176: 376 \$ 402$ \\
\hline Paraíba & $165: 852 \$ 312$ & $600 \$ 000$ & $166: 452 \$ 312$ \\
\hline Ceará & $155: 090 \$ 826$ & $6: 948 \$ 810$ & $162: 039 \$ 636$ \\
\hline Sergipe & $114: 168 \$ 876$ & - & $114: 168 \$ 876$ \\
\hline Goiás & $107: 461 \$ 000$ & $772 \$ 500$ & $108: 233 \$ 500$ \\
\hline Espírito Santo & $87: 583 \$ 413$ & - & $87: 583 \$ 413$ \\
\hline Mato Grosso & $84: 976 \$ 209$ & $38: 676 \$ 000$ & $123: 652 \$ 209$ \\
\hline Santa Catarina & $46: 775 \$ 244$ & $2: 060 \$ 001$ & $48: 835 \$ 245$ \\
\hline Rio Grande do Norte & $44: 956 \$ 921$ & $450 \$ 000$ & $45: 406 \$ 921$ \\
\hline Total & $17.644: 322 \$ 068$ & 4.028:797\$526 & 21.673:119\$594 \\
\hline
\end{tabular}

Quanto à organização do Quadro 35, efetuamos a classificação das Províncias mais significativas de acordo com os números apresentados na receita ordinária. Observamos que São Paulo figura na oitava posição dentre as 18 localidades existentes no período.

Sabemos das dificuldades e limitações para a pesquisa quanto ao uso do orçamento e não utilização dos balanços financeiros. Contudo, na ausência deste documento, cremos ser uma alternativa viável a apresentação das cifras que se esperava arrecadar, visto que tal expectativa ao menos nos oferece um entendimento acerca da representatividade econômica e fiscal de cada uma das Províncias brasileiras no período que estamos analisando.

Desta maneira, podemos compreender que mesmo nas Províncias menos significativas financeiramente, como no caso de São Paulo no período que nos ocupa, a importância arrecadatória por meio dos tributos incidentes sobre os gêneros, em especial os dízimos, fazia-se sentir e representava a mais importante ferramenta de recolhimento financeiro.

Dentre as justificativas para a manutenção desta sistemática fiscal é possível enaltecer o fato de a população, grosso modo, não sentir com tanta nitidez o peso das mãos do físco. 
Tal peso não podia ser ignorado quando tratamos da tributação que incidia diretamente sobre a propriedade e a renda. Além disso, havia no período um intenso conflito político no Brasil, inúmeras revoltas populares eclodiram em todas as regiões do país. Optar por um modelo tributário facilmente percebido pela população não seria uma estratégia assertiva e segura. Era mais prudente dar continuidade à sistemática adotada desde o início da colonização, a tributação indireta incidente sobre o consumo.

O Primeiro Reinado representou um período desafiador para os dirigentes e para a Nação. Havia a necessidade em entender a nova realidade vivenciada, bem como a aceitação e adaptação das deliberações advindas do Rio de Janeiro. Parte do território não reconhecia na figura de D. Pedro I o representante do governo. Em contrapartida, outra parcela defendia a legitimidade e permanência do Imperador no poder. Em 07 de abril de 1831 D. Pedro I, cedendo às pressões e procurando defender o trono da filha em Portugal, voltou atrás em sua decisão, estava findo o "dia do fico". Passados nove anos de sua permanência no Brasil, o Imperador retornou a Portugal e deixou como sucessor seu filho, que contava com somente cinco anos de idade.

Deste modo, o Período Joanino e o Primeiro Reinado expressam um importante momento para se repensar as estruturas brasileiras e iniciar algumas reformas administrativas necessárias. Todavia, foi o período subsequente que testemunhou importantes eventos e transformações na estrutura econômica, fiscal e política do Brasil.

\section{A Construção do Estado Nacional e os Direitos de Saída}

O Período Regencial foi palco de importantes alterações na estrutura política, administrativa e fiscal das Províncias. Através das medidas adotadas as autonomias locais se fortaleceram, sendo-lhes possível legislar em causa própria visando seus interesses e progressos particulares.

Compreender as motivações e ditames que nortearam tais decisões necessariamente nos impeli a revisitar a vasta discussão acerca de qual seria a constituição econômica e política mais apropriada para o Brasil. 
Inúmeros foram os debates ocorridos no Oitocentos acerca da centralização versus descentralização das autonomias políticas e financeiras provinciais. Se, por um lado, defendia-se a preservação de um Governo Geral forte e atuante, por outro, acreditava-se que o território brasileiro só poderia permanecer unido se maiores poderes fossem dados às Províncias.

Neste sentido, alegava-se que o Governo Geral não possuía competências para chegar até as extremidades, as localidades mais longínquas, ficando as necessidades destas à margem do que seria adequado para o seu desenvolvimento. A discussão iniciada na década de 1820 referente ao melhor modelo a ser empregado em terras brasileiras, e a defesa de uma maior liberdade às Províncias, inicia no Período Regencial seus primeiros passos concretos.

Ademais, não devemos nos esquecer que no ano de 1831, com a abdicação de D. Pedro I, chega ao poder e comando do Império uma classe política formada por brasileiros. Eram estes, e não mais os portugueses, que estavam na condução da Nação. Deste modo, coube à elite brasileira discutir, reivindicar e lutar por seus interesses. Nas palavras de Ivo Coser:

O novo Estado, portanto, surge de uma revolução sem revolução, conformado por elites políticas portadoras dos ideais da civilização e com a missão auto atribuída de forjar, ao longo do tempo, uma nação. Essa solução aborta uma revolução nacional-libertadora, que germinava desde as últimas décadas do século XVIII, mas não retira de cena nem seus personagens nem os princípios liberais que os animavam. O confronto entre elas, inclusive militar, dominará a cena política das três primeiras décadas do novo Estado, opondo dois princípios em torno do que deveria ser a concepção da Federação: o da centralização e o da descentralização, que estarão destinados, em nossa história política, a um movimento de gangorra, ora prevalecendo o primeiro, ora o segundo. (COSER, 2008, p. 10)

Os ideais conservadores eram representados pelos defensores da centralização do território e da tomada de decisão por parte de um governo central forte e atuante. De acordo com seus representantes, a unidade do país só poderia ser mantida mediante este modelo de governo.

Por outro lado, os princípios liberais pregavam a sustentação de uma maior autonomia administrativa, econômica, financeira e política para as localidades, as 18 Províncias que compunham o vasto território nacional. Sem este movimento, de acordo com essa corrente, o desenvolvimento da Nação como um todo jamais seria alcançado. 
Com o intuito de compreendermos detalhadamente as características destas duas linhas de pensamento, passemos à discussão acerca dos principais pontos debatidos e defendidos por cada uma.

\section{Os ideais centralizadores versus descentralizadores}

Os debates iniciados em solos brasileiros acerca da centralização ou descentralização política e econômica do país deram seus primeiros passos logo após a Proclamação da Independência. Deste modo, os dirigentes políticos brasileiros e a elite passaram uma década discutindo a questão até que as primeiras medidas em direção a um modelo de governo mais voltado à descentralização e maior autonomia às Províncias dessem início, no ano de 1832.

A principal diferença entre as correntes de pensamento reside no fato de como o Estado Nacional deveria ser alicerçado. Em linhas gerais, os centralizadores preconizavam a formação e fortalecimento do poder de cima para baixo, as diretrizes deveriam partir de um centro comum a todos. Este movimento, na visão dos descentralizadores, deveria ocorrer de maneira inversa.

De acordo com os centralizadores seria impossível a constituição do Estado Nacional mediante um poder central fraco e ausente. Somente um centro, dinâmico e atuante, seria capaz de promover o equilíbrio ente os interesses locais, evitar uma competição desenfreada entre as Províncias, com o predomínio das mais fortes sobre as mais fracas. Os defensores do federalismo argumentavam que seria exatamente a partir do fortalecimento das necessidades, interesses e realidades locais que o todo, o Estado Nacional, se tornaria mais forte e robusto.

A polêmica entre federalistas e centralizadores acerca da ideia de federação começa a partir das possíveis consequências desses traços. Para os centralizadores, a ausência de um poder central abre a possibilidade de que as províncias mais fortes controlem as mais fracas. A análise sobre tal preocupação ganha toda a sua dimensão histórico-política quando observamos uma outra dimensão da ideia de federação, qual seja, a rivalidade entre as províncias. Para a corrente federalista, ela revela-se como um aspecto positivo. Assim, queremos assinalar que a partir do debate entre federalistas e centralizadores podemos compreender a maneira pela qual essas correntes entendem a formação do interesse nacional. Os centralizadores rejeitam a noção de que o interesse da nação seja formado a partir do conflito entre os interesses provinciais; da soma aleatória destes, buscando se afirmar, emerge o conflito. Os centralizadores 
recuam e temem a ideia de que o Estado-nação seja o resultado do conflito de interesses provinciais, centrados na sua dinâmica local e provincial. A construção do Estado-nação requer, para os centralizadores, que ele não seja o resultado de um conflito, mas de uma ação intencional levada a cabo por um centro comum. (COSER, 2008, p. 108)

Destarte, a fim de melhor compreendermos as principais características de cada uma das propostas debatidas, apresentaremos separadamente suas ideias. Comecemos pela vertente centralizadora.

\section{Centralização}

Manter a unidade econômica, política e territorial era a bandeira defendida pelos centralizadores. De acordo com seus representantes, tais objetivos estariam seriamente comprometidos se ocorresse a instauração em solos brasileiros de um fortalecimento das localidades e uma maior rivalidade entre elas.

No argumento centralizador, o pacto entre as unidades que compõem a União deve estar organizado a partir de valores que neguem a dinâmica da competição entre as províncias. Para os centralizadores, o "centro comum" deve agir movido por uma ideia de nação formada por partes harmônicas, e a construção do Estado-nação iria exigir que os atores políticos transcendessem o interesse provincial, introduzissem valores que não estavam presentes na esfera provincial. Sem que isso ocorresse, tais interesses provinciais não chegariam a alcançar situações de paz entre as províncias. Para os centralizadores, do egoísmo auto referido delas emergiria a competição, e esta, de maneira alguma, vem a ser uma baliza segura para a construção do Estado-nação. (COSER, 2008, p. 106)

Conforme esta linha de raciocínio, somente o governo central poderia construir, gerir e administrar o Estado Nacional de maneira harmônica e visando o bem comum de todas as localidades. Apenas sob um prisma mais amplo é que se poderia chegar a uma conciliação de conflitos entre as Províncias, conciliação esta que trataria todas e todos de modo equânime, sem a subjugação dos mais fracos e distantes.

Ademais, o território nacional não deveria ser entendido como um espaço no qual seria permitida a competição desenfreada entre as diversas regiões. Diante desta realidade, seria incitada uma luta particular e egoísta dos interesses locais que comprometeria o crescimento e desenvolvimento do Império como um todo. A esfera macro, e não a micro, deveria ser considerada nesta questão.

O pensamento centralizador estabelecia que o pacto federativo não deveria ser pensado como o espaço pacífico para a competição entre os interesses 
provinciais, mas o lugar a partir do qual se impõe a "prosperidade geral". (COSER, 2008, p. 27)

Não obstante, a partir de uma perspectiva na qual os interesses locais ganhariam força e destaque, o que poderia vir a ocorrer? O fortalecimento das autonomias locais e maior poder de decisão de suas elites aceitaria a eterna e permanente submissão a um poder central? Estaria a unidade do território nacional comprometida? De acordo com os representantes da centralização, este cenário era verossímil.

$\mathrm{O}$ argumento centralizador conferia grande destaque ao exemplo da América hispânica. Para os centralizadores, os eventos que estariam ocorrendo nas antigas colônias espanholas serviam como parâmetro do que viria a acontecer caso o Brasil adotasse o federalismo. (COSER, 2008, p. 57)

Deste modo, verificamos que além das preocupações acerca da harmonia e prosperidade interna, também estava em pauta a hesitação sobre a impossibilidade da manutenção do território nacional no caso do deslocamento do poder decisório do centro para as periferias, as Províncias. Para os conservadores, os ideais federalistas não conduziriam o Brasil à construção do Estado Nacional, mas antes à deterioração do país, ocorrendo o mesmo que procedia na América espanhola. Analisemos os argumentos defendidos pelos oponentes da centralização.

\section{Descentralização}

De acordo com aqueles que defendiam o fortalecimento das autonomias locais, era pouco crível que em um país de dimensões territoriais tão vastas como o Brasil o poder central enxergasse as necessidades regionais e chegasse às extremidades. Não devemos perder de vista que estamos tratando de debates ocorridos no início do século XIX, sendo, no período, o transporte terrestre por meio de muares o principal meio de locomoção do território.

Além disso, em um Império no qual cada localidade possui suas particularidades, especificidades e necessidades, como conciliar interesses tão múltiplos e divergentes? O Brasil, em essência, era constituído pelas inúmeras facetas de um mesmo mosaico. Facetas estas profundamente particulares e únicas, mas, paralelamente, partes que compunham um todo. 
Desta maneira, para a corrente que defendia o fortalecimento das esferas de poder local, não seria possível a construção do Estado Nacional se as necessidades das Províncias fossem colocadas em segundo plano.

Podemos delinear o seguinte conteúdo na ideia de federação: o Estado é melhor administrado quando os interesses provinciais estão em primeiro plano. Para a corrente federalista, as províncias deveriam dispor do controle sobre a segurança, a administração e a prosperidade material. A dimensão privada se projeta sobre a esfera pública não na sua dimensão patrimonial, mas como precedência do interesse provincial como mola fundamental na montagem do Estado. (COSER, 2008, p. 43)

Sendo assim, de acordo com os federalistas, seria exatamente por meio do fortalecimento dos interesses das partes que o todo possuiria estruturas sólidas e prósperas. O desenvolvimento do Estado Nacional seria proporcionado pela salutar disputa entre as localidades.

Cada província irá considerar o pacto constitucional útil porque neste lhes será dada toda a liberdade para buscarem seus interesses particulares/provinciais, e a nação e o Estado-nação correspondente irá emergir do livre jogo desses interesses. (COSER, 2008, p. 46)

Ademais, para que esta saudável competição pudesse ocorrer, era necessária a instalação e atuação de um poder local forte e atuante. As Províncias necessitavam de todo um aparato administrativo para que suas elites se fizessem representar e discutir o bem comum da localidade, seus interesses e necessidades. É neste contexto que surge a defesa da criação das Assembleias Legislativas Provinciais.

A ideia de federação envolve um arranjo constitucional em que os interesses provinciais disponham de liberdade para agir. Somente um poder político que esteja próximo e sofra a influência destes interesses provinciais poderia moldar as leis nacionais; daí a importância da Assembleia Provincial como um poder gerado e próximo às necessidades locais. É a partir desse poder que a ação do Estado ganha sentido. (COSER, 2008, p. 49)

Deste modo, estavam dadas as balizas dos principais argumentos daqueles que defendiam a construção do Estado Nacional mediante o fortalecimento do poder local. De acordo com a sustentação de suas ideias, os interesses das elites locais deveriam ser a nota a reger a ópera imperial. Por meio da liberdade de ação e da sadia concorrência entre as Províncias seria possível ao Brasil conciliar e consolidar os múltiplos interesses que compunham as peças do mosaico. 
Entretanto, os liberais não eram céticos quanto ao fato de tais disputas poderem ocasionar sérios resultados deletérios às localidades menos aptas à competição. Todavia, na visão destes senhores, esta era a consequência natural a ser enfrentada para que o progresso geral pudesse ser alcançado:

No conceito de federação estava presente a ideia de um desenvolvimento desigual entre as províncias, e tal consequência era inevitável. O mal de um desenvolvimento desigual era preço a ser pago por um bem maior: 0 progresso advindo da competição. (COSER, 2008, p. 121)

Evidenciadas estas considerações, por meio desta breve explanação procuramos apresentar as principais características das discussões ocorridas nas décadas de 1820 e 1830 acerca de como deveria se dar a estruturação do Estado Nacional. Não obstante, também objetivamos expor as possíveis sequelas nocivas advindas de cada uma das vertentes discutidas e defendidas.

A partir deste momento nos ocuparemos em analisar os principais acontecimentos da década de 1830. Nosso foco irá se concentrar na construção das medidas adotadas no campo financeiro e fiscal. Novamente enaltecemos que não estamos diminuindo e muito menos negligenciando fatos importantes da nossa história. Contudo, necessitamos enfatizar que a proposta deste capítulo consiste em relatar a história econômica brasileira sob a ótica fiscal, este norte deve ser mantido.

\section{O fortalecimento das autonomias locais na década de 1830}

O início da década de 1830 foi marcado por profundas crises políticas e econômicas. Se, por um lado, o Brasil vivenciou a abdicação de seu Imperador e chegada ao poder das elites brasileiras ávidas em governar em prol de seus interesses. Por outro, a situação financeira do Tesouro era precária, situação essa já evidenciada nas linhas anteriores deste estudo.

As constantes utilizações de recursos provenientes das receitas extraordinárias e tomada de empréstimos no exterior, principalmente em instituições financeiras inglesas, aparentemente colocaram em xeque a possibilidade de implantação dos ideais conservadores que preconizavam o fortalecimento do poder e atuação do governo central. Como gerir o país uma vez que não havia recursos nos cofres públicos? Na análise de Furtado, 
O governo central, que enfrenta extraordinária escassez de recursos financeiros, vê sua autoridade reduzir-se por todo o país, numa fase em que as dificuldades econômicas criavam um clima de insatisfação em praticamente todas as regiões. (...) As inúmeras rebeliões armadas do Norte e a prolongada guerra civil do extremo sul são o reflexo desse processo de empobrecimento e dificuldades. (FURTADO, 2007, pp. 146-147)

Desta maneira, o somatório de um governo central endividado e empobrecido com o movimento político e econômico de desenvolvimento dos interesses das elites locais, elites estas que em parte estavam no comando do Império, estruturou as bases necessárias para a descentralização vivenciada na década de 1830 .

Dentre as medidas financeiras e fiscais, havia por parte dos dirigentes do Império a preocupação em promover a separação das receitas tributárias entre as rendas geral e provincial. De acordo com os defensores do federalismo, o fortalecimento das autonomias locais não seria possível mediante a ausência de renda própria das Províncias.

No entanto, não devemos nos esquecer que no período em pauta o recolhimento tributário era promovido nos órgãos fazendários localizados nas Províncias. Somado a este fato, não havia a diferenciação entre os cofres que deveriam promover o recolhimento dos recursos do Império e os recursos provinciais. O observado era a destinação quase integral das receitas fiscais para o suprimento das despesas da Província. Somente o excedente financeiro, quando houvesse, deveria ser direcionado ao Rio de Janeiro. Raras eram as ocasiões nas quais as Províncias enviavam as sobras fiscais, pois, de acordo com o que se alegava, não havia sobras.

Assim que assumiram o comando do país, os representantes do governo iniciaram as discussões acerca da separação das rendas fiscais ente o Império e as Províncias:

Em maio de 1831 entrava em questão a emenda que discriminava as rendas provinciais das rendas do governo central, e marcava a contribuição que cada província deveria concorrer às despesas gerais da nação. A discussão possui importância porque nela é mobilizada a ideia de federação. (...), o estabelecimento da distinção não implicava o separatismo, porque as províncias não estariam separadas do Império. A emenda marcaria a distinção entre o que era geral, pertencia ao poder central, e o que dizia respeito exclusivamente à província. Isso se fazia necessário porque os "interesses particulares das províncias" eram distintos dos interesses "gerais do Império". (COSER, 2008, pp. 115-116)

Conforme podemos observar, a separação das rendas em geral e provincial caracterizava um movimento positivo não somente para as Províncias, uma vez que também estavam em pauta os interesses do Império e a discriminação de sua fonte de recursos. Por meio 
da Lei Orçamentária do ano de 1832 ocorreu a separação das rendas em geral e provincial.

Vejamos como se deu a repartição dos recursos fiscais:

Lei de 24 de outubro de 1832 - Orça a receita, e fixa a despesa para o ano financeiro de 1833-1834.

Art. 1 - As despesas públicas, que até agora tem estado a cargo do Tesouro Nacional, ficam divididas em - Despesa Geral - e - Despesa Provincial.

Art. 78 - Pertencem à Receita Geral:

$\S 1^{\circ}$ - Direitos, que se arrecadam na Alfândega, por importação, exportação, baldeação e reexportação; e emolumentos, que se cobram nas mesmas Alfândegas, de ofícios, que passarão para a Fazenda Pública.

$\S 2^{\circ}$ - Meio por cento de assinados das Alfândegas.

$\S 3^{\circ}$ - Armazenagem, ancoragem e faróis.

$\S 4^{\circ}$ - Contribuição da Junta do Comércio sobre volumes, e embarcações, inclusive os das nações, com quem não há tratados, e imposto denominado de Banco sobre as que navegam de barra fora, inclusive as estrangeiras, com cujas nações existam tratados.

$\S 5^{\circ}$ - O imposto de quinze por cento das embarcações estrangeiras, que passam a ser nacionais, e o de cinco por cento da venda das nacionais.

$\S 6^{\circ}$ - Direitos de vinte e cinco por cento do ouro.

$\S 7^{\circ}$ - Sisa da venda dos bens de raiz.

$\S 8^{\circ}$ - Porte de Correios de mar e terra.

$\S 9^{\circ}$ - Impostos para a Caixa de Amortização da dívida pública.

$\S 10^{\circ}$ - Dízimos do açúcar, algodão, café, tabaco, e fumo, e a contribuição das sacas de algodão.

$\S 11^{\circ}$ - Dízimos do gado vacum e cavalar; vinte por cento dos couros do Rio Grande do Sul, e os quarenta por cento na aguardente de consumo na Bahia para resgate das cédulas, na forma do Art. setenta e seis.

$\S 12^{\circ}$ - Selo das Mercês, Dízima da Chancelaria, novos e velhos direitos das Graças e Títulos expedidos pelo Poder executivo e Tribunais; e emolumentos, que se cobram no Tribunal Supremo da Justiça.

$\S 13^{\circ}$ - Chancelaria da Imperial Ordem do Cruzeiro, e das três Ordens Militares, Mestrado, e três quartos das Tenças.

$\S 14^{\circ}$ - Meios soldos das Patentes Militares, e contribuição do Monte Pio.

$\S 15^{\circ}$ - Matrículas dos Cursos Jurídicos, e Academias.

$\S 16^{\circ}$ - Rendimentos das Casas da Moeda.

$\S 17^{\circ}$ - Venda do pau brasil, e dos Próprios Nacionais.

$\S 18^{\circ}$ - Renda diamantina, e foros de terrenos da Marinha.

$\S 19^{\circ}$ - Bens de defuntos e ausentes, cobrança da dívida ativa, e da Bula Cruzada.

$\S 20^{\circ}$ - Emissão de apólices, juros das apólices dos empréstimos estrangeiros.

$\S 21^{\circ}$ - Rendas eventuais, e não classificadas, que provém dos Arsenais do Exército e da Marinha, e da venda de vasos de guerra, limpa das Alfândegas, rendimentos da Fábrica de Pólvora, da Tipografia Nacional, reposições, e emolumentos que se cobram pelas Intendências de Marinha dos Ofícios, que passaram à Fazenda Pública.

$\S 22^{\circ}$ - Os soldos e sobras da receita geral, e provincial.

Art. 80 - As rendas gerais serão escrituradas em livro à parte, e arrecadadas uniformemente em todo o Império, segundo os Regulamentos ora existentes, ou que forem de novo organizados pelo Ministro da Fazenda. O 
seu produto será recolhido em cofre distinto, e distribuído segundo as disposições do mesmo Ministro em Tribunal, e na conformidade da presente Lei.

Art. 81 - A receita e despesa geral continuará a ser fixada pela Assembleia Geral sobre o orçamento do Ministro da Fazenda.

Art. 82 - Às Províncias, cujas rendas não chegarem para a sua despesa provincial, serão socorridas pelo cofre da receita geral da respectiva Província, independente da Ordem do Ministro e Presidente do Tesouro Nacional; e por consignações destinadas por ele, quando não haja fundos no cofre da receita geral da mesma Província.

Título V - Receita Provincial - Capítulo Único

Art. 83 - Pertencem à receita provincial todos impostos ora existentes não compreendidos na receita geral. (LEI de 24 de outubro de 1832)

Por meio da análise desta Lei Orçamentária, podemos averiguar que a principais fontes de recursos ficais foram destinadas aos cofres do Império. As rendas exteriores, representadas pelos tributos alfandegários, constituíam a mais importante ferramenta de recolhimento fiscal no período. Não houve por parte do Congresso sequer a preocupação em promover a divisão de tais recursos entre a renda geral e provincial. Além disso, os dízimos incidentes sobre os principais gêneros comercializados receberam a mesma destinação que as receitas alfandegárias.

Deste modo, podemos afirmar que, em essência, a Lei Orçamentária de 1832 não promoveu uma melhora na situação fiscal do Brasil como um todo. Ao contrário, o que ocorreu foi tão somente a transferência e concentração dos recursos fiscais para os cofres da renda geral. Se, antes de 1832, havia a especificação em enviar as sobras provinciais para os cofres do Império, o que constatamos neste momento é um movimento pendular, no qual, por meio do Art. 82, ficou determinado que o cofre geral localizado na respectiva Província seria obrigado a socorrer o cofre provincial em caso de necessidade.

Sendo assim, tanto as principais fontes de recursos ficaram concentradas nas mãos do Império quanto a alternância de postura neste emblemático tabuleiro fiscal. De receptora das sobras fiscais, quando houvesse, a renda geral passou a provedora de recursos, quando necessário e solicitado. Diante deste fato fica o questionamento: seriam mesmo os ideais descentralizadores que estavam ditando as regras deste intricado jogo de xadrez?

Mediante tais reflexões, podemos constatar que na realidade eram os princípios de fortalecimento do poder central que estavam sendo regidos quando da separação das 
rendas em geral e provincial. Lembremo-nos da situação financeira do Império em fins de 1820 e início de 1830: déficits constantes e escassez de recursos.

Contudo, a atmosfera política não era a mesma observada quando da formulação da Constituição de 1824. Paralelamente, não havia no comando do Brasil um Imperador que pudesse exercer o seu Poder Moderador. Isto posto, seria de se esperar que as elites locais também efetuassem os seus estratégicos movimentos enxadristas.

No que se refere ao federalismo, a Constituição de 1824 era excessivamente centralizadora para um país tão vasto e com tantos interesses conflitantes. A reação já se materializara em 1824 em uma revolta que abrangeu várias províncias do Norte, sob a liderança de Pernambuco. Todas as províncias desejavam maior autonomia. Alguns porta-vozes desses interesses iam ao extremo de propor um federalismo republicano. (...) A Constituição foi reformada em 1834 por uma Ato Adicional votado pela Câmara, que recebera para isso mandato especial dos eleitores. Foi a única reforma constitucional feita durante o Império. O Ato Adicional concedeu às províncias Assembleias e orçamentos próprios e deu a seus presidentes poderes de nomeação e transferência de funcionários públicos, mesmo quando pertencentes ao governo geral. $\mathrm{O}$ novo sistema só não era plenamente federal porque os presidentes continuavam a ser indicados pelo governo central. (CARVALHO, 2012, pp. 89-90)

Portanto, por meio da promulgação do Ato Adicional de 1834 as localidades provinciais passam a adquirir a tão ambicionada autonomia. São estes os primeiros passos necessários para a elaboração de seus orçamentos e criação de suas respectivas fontes de recursos financeiros. Além disso, por mais que não tenha se concretizado, não podemos deixar de expor a tentativa das elites provinciais em reverter o estabelecido na Lei Orçamentária de 1832, quando da divisão das rendas em geral e provincial. Por meio de discussões no Legislativo, buscou-se promover a concentração das rendas tributárias nas mãos das Províncias, devendo estas contribuir com uma cota fixa para a renda geral:

Na sessão de 3 de julho de 1834, estava em discussão a seguinte proposta: as Assembleias Provinciais ficavam encarregadas de todos os impostos, cabendo repassar um percentual à nação, como maneira de sustentar a União. Para realizar tal contribuição, as províncias teriam ampla liberdade na criação de impostos; o poder central não poderia coibir a criação de impostos pela província, já que esta tinha para com a nação apenas a obrigação de contribuir com um percentual fixo para as suas despesas. (COSER, 2008, p. 109)

Bem sabemos que tais medidas não foram colocadas em prática. Contudo, este fato não poderia nos passar despercebido, pois ele ilustra a disputa de forças existente no período 
entre as correntes centralizadoras e descentralizadoras. Observemos adiante o estabelecido no Ato Adicional de 1834:

Lei $\mathrm{n}^{\circ} 16$, de 12 de agosto de 1834

Art. 1 - O direito reconhecido e garantido pelo art. 71 da Constituição será exercitado pelas Assembleias, que, substituindo os Conselhos Gerais, se estabelecerão em todas as Províncias com o título de Assembleias Legislativas Provinciais.

Art. 10 - Compete às mesmas Assembleias legislar:

$\S 4^{\circ}$ - Sobre a polícia e economia municipal, precedendo propostas das Câmaras.

$\S 5^{\circ}$ - Sobre a fixação das despesas municipais e provinciais, e os impostos por elas necessários, com tanto que estes não prejudiquem as imposições gerais do Estado. As Câmaras poderão propor os meios de ocorrer às despesas dos seus municípios.

$\S 6^{\circ}$ - Sobre repartição de contribuição direta pelos municípios da Província, e sobre a fiscalização do emprego das rendas públicas provinciais e municipais, e das contas da sua receita e despesa. As despesas provinciais serão fixadas sobre orçamento do Presidente da Província, e as municipais sobre orçamento das respectivas Câmaras. (LEI n ${ }^{\circ} 16$, de 12 de agosto de 1834)

Destarte, estavam dadas as diretrizes para o estabelecimento e funcionamento das Assembleias Legislativas a fim de que cada Província pudesse conduzir da maneira que lhe conviesse seus interesses locais. Por meio da atuação das Assembleias os assuntos fiscais ganharam um importante porta voz, uma vez que entrava em vigor o órgão responsável pela elaboração das receitas e despesas. Além disso, as Assembleias eram possuidoras de ampla autonomia para criar os impostos que seriam mais adequados, de acordo com a realidade econômica e fiscal provincial.

Não obstante, também coube às Assembleias um importante papel na discussão acerca das divisões de renda estabelecidas na Lei Orçamentária do ano de 1832. Como já mencionado, as principais fontes de recursos foram direcionadas para a receita imperial. No entanto, na Lei Orçamentária Geral de 1835 ocorreu o compartilhamento da receita fiscal proveniente dos dízimos incidentes sobre as principais mercadorias exportadas entre a renda geral e a renda provincial.

Lei n ${ }^{\circ} 99$, de 31 de outubro de 1835 - Orçando a receita e fixando a despesa para o ano de 1836 a 1837.

Art. 9 - Do $1^{\circ}$ de Julho de 1836 em diante serão arrecadados e pela maneira abaixo especificada as seguintes imposições: 
$\S 6^{\circ}$ Os dois por cento de exportação de produção brasileira, ficam elevados a sete por cento, abatidos os cinco adicionais no que pagarem de dízimo aqueles gêneros que os pagavam na exportação para fora do Império, cessando qualquer outra imposição sobre a mesma exportação; ficando o resto da quota dos dízimos pertencendo à renda das respectivas Províncias. Esta disposição não compreende os couros do Rio Grande do Sul, que continuarão a pagar os vinte por cento. (LEI n ${ }^{\circ}$ 99, de 31 de outubro de 1835)

Deste modo, por meio da criação das Assembleias Legislativas, no ano de 1834, e do compartilhamento da receita dos dízimos, em 1835, estavam estabelecidos importantes instrumentais para a estruturação da autonomia financeira local. As Províncias agroexportadoras em muito iriam se beneficiar nas décadas seguintes destas características, em especial aquelas que se consolidaram como importantes produtoras e exportadoras de café.

De acordo com os representantes do liberalismo, estes foram importantes passos dados. No entanto, esta análise não levava em consideração a situação das Províncias que não teriam condições de tirar proveitos destas medidas.

Segundo o deputado mineiro, a manutenção do Ato Adicional justificavase porque nas províncias mais civilizadas a descentralização não implicava conflitos com o poder central. Teófilo Ottoni defende o Ato Adicional a partir dos interesses das províncias mais civilizadas. O Ato permitia que elas buscassem seus objetivos sem ferir a unidade nacional. Porém, seu argumento silencia quanto às regiões menos civilizadas. Seu silêncio é coerente com a ideia de federalismo. Nesse arranjo constitucional, a solidariedade entre as partes nasce das vantagens que cada província obtém do pacto. Do ponto de vista das províncias mais civilizadas, para algumas - aquelas que na competição interna são as mais aquinhoadas - a descentralização cumpre plenamente sua finalidade. (COSER, 2008, p. 249)

Tal ponto de vista acerca das vantagens que pudessem ser advindas das autonomias financeiras locais, e deste novo rearranjo institucional e fiscal, também era compartilhado por representantes da corrente conservadora. Na visão do Visconde do Uruguai era impossível conciliar os múltiplos interesses existentes.

No seu relatório de presidente de província de 1838, Uruguai percebia que o café despontava como a principal atividade econômica do país. Entretanto, no excerto anterior, Uruguai não mencionava que a partir dos interesses da província do Rio de Janeiro pudessem ser construídos laços entre as diversas partes do Império. Ao contrário, negava explicitamente que deles pudesse ser feita uma política capaz de unir a nação. Devemos ponderar que, para Uruguai, os interesses de uma província marcada pela produção cafeicultora não eram os mesmos daqueles de uma província voltada para a produção de carne (como a do Rio Grande do Sul) ou com partes direcionadas para o abastecimento do mercado interno (como o sul 
de Minas); ou ainda de províncias pouco habitadas, como as do centro-sul ou mesmo a do Rio Negro. Entre elas não existe, no plano do interesse, um elemento comum. (COSER, 2008, pp. 248-249)

Sendo assim, a formação e consolidação das autonomias locais no período em pauta em muito favoreceu as localidades que tinham condições de fazer parte deste novo rearranjo institucional.

Voltando à analogia do jogo de xadrez, mas passando neste momento a analisar os movimentos a partir das peças do tabuleiro e não mais das estratégias em disputa, "rei, rainha, bispos, cavalos e torres" - representados em especial pelos cafeicultores localizados no Rio de Janeiro, Minas Gerais e, principalmente, São Paulo no decorrer das décadas seguintes - muito tinham a comemorar, pois seus interesses estavam defendidos e garantidos. Às demais Províncias restava o ato em se sacrificar em prol da vitória do "rei".

Desta maneira, procuramos apresentar as principais medidas adotadas no Período Regencial que viriam a favorecer as Províncias agroexportadoras. De posse das informações apresentadas até o momento, temos condições de analisar a realidade vivenciada pela Província paulista quando da separação das rendas em geral e provincial, criação da Assembleia Legislativa e compartilhamento da receita do dízimo, bem como averiguar de que modo o café beneficiou e influenciou o desenvolvimento da economia e fiscalidade de São Paulo no decorrer do século XIX.

\section{A Província de São Paulo}

Em meados da década de 1830 o território paulista ainda não figurava como a Província mais próspera do Império. Neste momento, o que se observava na região era uma mescla de atividades econômicas e sociais. Em algumas partes a cultura cafeeira avançava, trazendo consigo a promessa do desenvolvimento econômico; em outras, a tradicional cultura canavieira absorvia grande parte dos recursos; e em todas, com maior ou menor intensidade, havia a lavoura dedicada à produção de gêneros de subsistência, assim como a criação de gado e pequenos animais.

No ano de 1836, por meio de um estudo encomendado pelo então Presidente da Província, Rafael Tobias de Aguiar, o marechal Daniel Pedro Müller efetuou um levantamento acerca das principais características econômicas e demográficas do território paulista. 
No tocante aos assuntos econômicos, era grande a importância da chamada indústria agrícola na produção provincial. Conforme demonstrado no Quadro 36, dentre os produtos mais comuns, destacam-se o açúcar, o café, o arroz, o feijão, a aguardente e o milho. Ao lado destes, outros 22 gêneros ou produtos foram localizados, dentre os quais podemos citar o toucinho, a erva-mate ${ }^{32}$ e a batata, além de alguns produtos manufaturados, tais como os tecidos de algodão, as telhas de barro, a rapadura, o carvão e a marmelada.

Quadro 36 - Produção Total da Província de São Paulo, (1836)

\begin{tabular}{|l|r|l|l|r|l|}
\hline \multicolumn{1}{|c|}{ Produto } & \multicolumn{2}{c|}{ Quantidade } & \multicolumn{2}{c|}{ Produto } & \multicolumn{2}{c|}{ Quantidade } \\
\hline Café & 588.136 & arrobas & Rapaduras & 46.300 & unidades \\
\hline Açúcar & 563.108 & arrobas & Pano de algodão & 600 & varas \\
\hline Aguardente & 46.728 & canadas & Chá & 1.970 & libras \\
\hline Arroz & 341.220 & alqueires & Telhas & 32.000 & unidades \\
\hline Farinha de mandioca & 79.765 & alqueires & Marmelada & 92 & arrobas \\
\hline Feijão & 237.116 & alqueires & Batatas & 2.451 & alqueires \\
\hline Milho & 3.870 .020 & alqueires & Farinha de milho & 26 & alqueires \\
\hline Azeite de amendoim & 666 & medidas & Trigo & 10 & unidades \\
\hline Fumo & 11.773 & arrobas & Cabras & 485.881 & arrobas \\
\hline Algodão em rama & 9.282 & arrobas & Erva Mate & 1.623 & unidades \\
\hline Cal & $1.232,50$ & moios & Vigas & 2.480 & unidades \\
\hline Taboados & 2.087 & dúzias & Embé & 100 & unidades \\
\hline Peixe seco & 4.060 & arrobas & Canoas & 310 & unidades \\
\hline Porcos & 69.158 & unidades & Chapéus & 198 & dúzias \\
\hline Gado cavalar & 11.400 & unidades & Esteiras & 40 & arrobas \\
\hline Gado muar & 2.268 & unidades & Embaúva & 70 & medidas \\
\hline Gado vaccum & 35.573 & unidades & Carvão & 110 & dúzias \\
\hline Gado lanígero & 5.799 & unidades & Ripas & & \\
\hline Toucinho & 12.990 & arrobas & & Fonte: (MÜLLER, 1978, p. 129) & Valor total 4.766:918\$493 \\
\hline
\end{tabular}

Sobre as finanças paulistas, dada a recente criação da Assembleia Legislativa, o marechal limitou-se a apresentar os números referentes ao ano financeiro 1835-1836, além de descrever quais eram os impostos arrecadados pelas repartições provinciais e de que maneira era feito o recolhimento.

\footnotetext{
32 No período em pauta a região que atualmente constitui o Estado do Paraná compunha o território da Província de São Paulo, a separação dos territórios ocorreu somente no ano de 1853. Deste modo, natural a erva-mate figurar entre os principais gêneros agrícolas produzidos nas terras paulistas.
} 
Segundo o registro de Müller, eram recolhidos pelas autoridades da Província um total de dezesseis impostos provinciais; além de mais quatro pertencentes à renda geral do Império, de forma a fazer parte da receita provincial paulista as seguintes imposições ${ }^{33}$ :

- Novos e velhos direitos: instituído em 1832, era recolhido sobre as Provisões, Diplomas e Papéis Forenses, sendo isentos de tal cobrança os funcionários das Tesourarias, Alfândegas, Mesas de Rendas, professores públicos, professores de cursos jurídicos, juízes de direito e juízes municipais, além dos empregados militares e da Marinha. Cobrado pelos Coletores.

- Novos impostos: criado como forma de financiar a reconstrução da alfândega de Lisboa depois do terremoto de 1755, acabou sendo utilizado para pagamento de oficiais de $2^{\mathrm{a}}$ linha e posteriormente para obras públicas. Era proveniente de várias cobranças: imposição de $6 \$ 400$ réis aos armazéns da cidade e vilas de serra acima, dos gêneros miúdos que passam no Cubatão para a vila de Santos; cobrança de $4 \$ 000$ das tabernas da mesma vila; cobrança de $\$ 320$ por uma besta, $\$ 200$ por um cavalo e $\$ 100$ por uma cabeça de gado vacum que passam no registro de Sorocaba. Cobrado por coletores.

- Subsídio literário: estabelecido em 1772 em benefício da instrução pública. Cobrança de $\$ 820$ de toda e qualquer rês morta e comercializada. Cobrado por coletores.

- Carne verde: imposição instituída em 1809 e modificada em 1835, previa a cobrança de $1 \$ 600$ de toda rês morta e comercializada. Cobrada por coletores.

- Dízimos: cobrança sobre os gêneros exportados para fora da província, sendo a alíquota de $10 \%$ aplicada sobre os gêneros agrícolas e a de 5\% aplicada sobre os gêneros manufaturados; com exceção dos dízimos sobre açúcar, café, algodão, tabaco e fumo, além do gado vacum e cavalar, quando estes fossem exportados para fora do Império. Cobrados nas alfândegas em Santos e Paranaguá, e por coletores nas demais partes da Província.

- Décima dos prédios urbanos: cobrado desde 1808/1809 nas vilas com cem casas ou mais. Cobrada por coletores.

- Décima dos legados e heranças: cobrança imposta em 1809; consistia em cobrar $10 \%$ do valor dos bens deixados a herdeiros que não fossem ascendentes ou descendentes e da quinta parte de toda a herança abintestada sendo parente até segundo grau. Cobrada por coletores.

- Direitos do Rio Negro: cobrança instituída em 1747, consistindo em pagar $2 \$ 500$ por cada burro ou besta; $2 \$ 000$ por cada cavalo e $\$ 960$ réis por cada égua que se criam além dos limites da província até o Registro. Cobrado pelos coletores.

- 20\% da aguardente de consumo: cobrança instituída em 1835, sobre o consumo de qualquer aguardente - nacional ou estrangeira. Cobrado pelos coletores.

\footnotetext{
${ }^{33}$ Notamos algumas diferenças entre o levantamento efetuado por Müller e os dados apresentados no “Quadro 34 - Receita da Província de São Paulo" para o ano de 1827. No entanto, em ambos os casos, optamos por manter a fidelidade apresentada nas fontes documentais.
} 
- Meia sisa dos escravos ladinos: pagamento de 5\% do preço de venda do escravo. Quando a negociação envolvia a troca de um escravo por outro, a cobrança recaía apenas sobre os valores em espécie que porventura fizessem parte da negociação. Cobrado pelos coletores.

- Foros e arrendamentos: pagamento de algum foro, ou aluguel dos bens de raiz pertencentes à Fazenda Pública. Cobrado pelos coletores.

- Emolumentos da secretaria: cobrança de $1 \$ 920$ réis do registro das patentes de confirmação e decretos, além de $\$ 960$ réis do registro das provisões e portarias das secretarias de estado, e mesmo valor de quaisquer certidões. Cobrados nas competentes repartições.

- Tipografia: cobrança pelas folhas remetidas às Câmaras e pela impressão de obras de particulares. Cobrada pelos administradores.

- Despachos de embarcações: taxas que pagam os passaportes das embarcações, tanto nacionais como estrangeiras. Cobrados pela Secretaria do Governo.

- Prisão com trabalho: produto do trabalho ou de produtos produzidos pelos presos. Cobrança feita com base nos registros do Administrador.

- Contribuição para Guarapuava: criada em 1809 para custear as despesas com a expedição e conquista dos campos de Guarapuava. Arrecadada por meio de taxas diversas sobre animais: $\$ 875$ por cada muar arreado desde Curitiba até Sorocaba; $\$ 750$ por cada cavalo e $\$ 240$ por cada cabeça de gado vacum. Se criadas no Sul, Serra de Vacaria, e Lages, era cobrado $\$ 160$ por cada besta e $\$ 220$ por cada cavalo. Cobrada pelo coletor da vila de Sorocaba. (MÜLLER, 1978, pp. 212-213)

Acerca da representatividade arrecadatória de cada uma das fontes tributárias, o marechal apresentou o Balanço da Receita Provincial para o ano financeiro de1835-1836. Segundo Müller:

Na receita estavam incluídas as cobranças dos últimos anos, de 1833 a 1834. Na rubrica passagens dos rios estavam incluídas as dívidas atrasadas, já abolidas na data da publicação pela lei provincial de março de 1836; a rubrica imposto para o Banco era referente a atrasados de exercícios anteriores; e a receita eventual era proveniente da lei de 11 de abril de 1835. (MÜLLER, 1978, p. 215)

As receitas recolhidas no ano 1835-1836, apresentadas por Müller, foram sumarizadas no

Quadro 37.

Quadro 37 - Resumo do Balanco da Receita de São Paulo, (1835-1836)

\begin{tabular}{|l|c|c|}
\hline \multicolumn{1}{|c|}{ Receita } & Valor & $\%$ \\
\hline Animais do Rio Negro & $81: 869 \$ 950$ & $28,00 \%$ \\
\hline Dízimos & $31: 351 \$ 648$ & $10,70 \%$ \\
\hline Décima dos legados & $28: 010 \$ 910$ & $9,60 \%$ \\
\hline Novo imposto e dos animais em Sorocaba & $22: 074 \$ 216$ & $7,50 \%$ \\
\hline Décima dos prédios urbanos & $19: 053 \$ 703$ & $6,50 \%$ \\
\hline Carne verde e subsídio literário & $19: 170 \$ 442$ & $6,50 \%$ \\
\hline Meia sisa dos escravos & $16: 475 \$ 977$ & $5,60 \%$ \\
\hline
\end{tabular}




\begin{tabular}{|l|c|c|} 
Contribuição de Guarapuava & $9: 595 \$ 140$ & $3,30 \%$ \\
\hline 20\% da aguardente & $9: 331 \$ 440$ & $3,20 \%$ \\
\hline Passagens e rios & $7: 476 \$ 635$ & $2,60 \%$ \\
\hline Imposto para o Banco & $1: 926 \$ 921$ & $0,70 \%$ \\
\hline Multas a mestres de barcos & $1: 816 \$ 282$ & $0,60 \%$ \\
\hline Dita não classificada & $1: 495 \$ 069$ & $0,50 \%$ \\
\hline Novos e velhos direitos & $1: 251 \$ 066$ & $0,40 \%$ \\
\hline Foros e arrendamentos & $778 \$ 354$ & $0,30 \%$ \\
\hline Despachos de embarcações & $551 \$ 990$ & $0,20 \%$ \\
\hline Tipografia & $690 \$ 250$ & $0,20 \%$ \\
\hline Emolumentos da secretaria & $154 \$ 120$ & $0,10 \%$ \\
\hline Selo & $212 \$ 856$ & $0,10 \%$ \\
\hline Casa de prisão com trabalho & $225 \$ 699$ & $0,10 \%$ \\
\hline Aldeamento de Guarapuava & $249 \$ 960$ & $0,10 \%$ \\
\hline Casas de leilão & $40 \$ 000$ & $0,00 \%$ \\
\hline Receita eventual & $38: 898 \$ 731$ & $13,30 \%$ \\
\hline Total & $292: 701 \$ 359$ & $100,00 \%$ \\
\hline
\end{tabular}

Optamos por efetuar a organização do Quadro 37 de acordo com a representatividade arrecadatória do tributo. Sendo assim, verificamos que após a separação das rendas em geral e provincial, os dízimos passaram a figurar como a segunda principal ferramenta de recolhimento da Província, e não mais a primeira, conforme ilustrado nas arrecadações do ano de 1827 (Quadro 34).

Ademais, devemos evidenciar e relembrar o fato de, no ano de 1821, por meio de Decreto estabelecido por D. João VI, ficou determinado que os dízimos deixariam de ser arrecadados nas localidades produtoras e passariam a ser recolhidos nas entradas das vilas, nas Alfândegas, nos Portos Secos e nos Registros. Acompanhamos os desafios e percalços acerca desta determinação e verificamos que tal diretriz passou a ser cumprida na Província de São Paulo no ano de 1829.

A consciência deste fato é de suma importância para analisarmos o desenvolvimento do dízimo no território paulista no decorrer do Segundo Reinado. Deixando de ser recolhido na localidade produtora, o dízimo passou a tributar, principalmente, as mercadorias que eram enviadas para outras Províncias, bem como os produtos exportados para fora do Império.

Isto posto, passemos à análise das Leis Orçamentárias paulistas. Por meio destes documentos é possível verificar a expectativa arrecadatória com os dízimos, posteriormente denominados direitos de saída, no decorrer de quase seis décadas, 1835 a 
1889. Paralelamente, também se torna possível traçar um comportamento de longo prazo acerca das relações existentes entre esta fonte tributária e a realidade econômica vivenciada pela Província de São Paulo no período que no momento nos ocupa ${ }^{34}$.

\section{As Leis Orçamentárias paulistas}

Por meio do estudo das Leis Orçamentárias, disponibilizadas no Acervo Histórico da Assembleia Legislativa do Estado de São Paulo, é possível observar a representatividade que os dízimos, posteriormente denominados direitos de saída, passaram a adquirir na receita orçada paulista ao longo das décadas.

O estudo a ser apresentado nas páginas vindouras foi estruturado de acordo com a seleção de algumas Leis Orçamentárias distribuídas ao longo do período, entre 1835 a 1889. Em um primeiro momento foram selecionadas a primeira e a última Leis Orçamentárias, em seguida, selecionamos leis intermediárias referentes ao ano inicial de cada década, o que resultou nas leis orçamentárias dos anos de 1835, 1840, 1850, 1860, 1870, 1880 e 1889. A única exceção foi para o ano de 1860, pois dada a ausência da Lei para este ano foi selecionado o documento do ano seguinte, 1861. Ademais, também foram elaboradas tabelas destacando apenas os valores referentes aos dízimos para todo o período analisado.

Desta forma, a Tabela 1 traz uma síntese do valor total das receitas orçadas, cuja observação nos permite verificar que houve uma significativa elevação em termos do total orçado pela Província, o que certamente se vincula ao próprio desenvolvimento econômico paulista observado no período. Os valores são apresentados também em libras esterlinas. Tal procedimento é necessário pois no período 1835-1889 houve considerável variação do poder aquisitivo da moeda nacional, em especial durante a Guerra do Paraguai, 1864 a 1870, e durante o socorro às vítimas da seca de 1878. Nessas ocasiões,

\footnotetext{
${ }^{34}$ Temos ciência que a utilização dos Balanços seria o mais adequado para a avaliação do recolhimento tributário. Contudo, na falta destes documentos, e procurando compreender os movimentos fiscais no período imperial, optamos pela utilização dos Orçamentos provinciais paulistas. Cremos ser esta fonte documental uma valiosa ferramenta a fim de, se não preencher as lacunas que se apresentam, ao menos iluminar os caminhos a serem percorridos. Ademais, de acordo com a expectativa arrecadatória de cada tributo existente no período, é possível apreender os movimentos econômicos e averiguar de que maneira esta temática influenciava a questão fiscal.
} 
a política monetária expansionista financiou os déficits do governo, fazendo crescer os níveis de inflação e alterando o poder aquisitivo externo da moeda nacional ${ }^{35}$.

Observando os valores em libras esterlinas, a receita paulista passa de $£ 39.846$ - valor orçado em 1835 - para $£ 557.699$ - valor orçado em 1889. Em termos percentuais, isso significa um aumento de quase $1.300 \%$. Em boa medida, essa evolução constitui consequência natural do desenvolvimento econômico da Província paulista nesse momento. A produção açucareira e depois a cultura cafeeira desenvolveram-se rapidamente, em especial o chamado complexo cafeeiro, característico da segunda metade do século. Por meio de tal expansão, torna-se viável o entendimento da representatividade que os direitos de saída passam a obter nos valores orçados.

\section{Tabela 1 - Evolucão da Receita Provincial Orçada. São Paulo, (1835-1889)}

\begin{tabular}{cccc}
\hline Ano & $\begin{array}{c}\text { Receita Orçada } \\
\text { (valores nominais) }\end{array}$ & $\begin{array}{c}\text { Receita Orçada } \\
\text { (valores em libras esterlinas) }\end{array}$ & $\begin{array}{c}\text { Variação \% em relação ao } \\
\text { período anterior } \\
\text { (em libras esterlinas) }\end{array}$ \\
\hline 1835 & $243: 700 \$ 000$ & 39.846 & - \\
1840 & $365: 648 \$ 000$ & 47.241 & $18,56 \%$ \\
1850 & $486: 450 \$ 000$ & 58.278 & $23,36 \%$ \\
1861 & $1.116: 513 \$ 590$ & 118.905 & $104,03 \%$ \\
1870 & $2.430: 000 \$ 000$ & 224.356 & $88,69 \%$ \\
1880 & $3.732: 371 \$ 176$ & 346.553 & $54,47 \%$ \\
1889 & $5.061: 120 \$ 000$ & 557.699 & $60,93 \%$ \\
\hline \multicolumn{4}{c}{ Fonte: (ALESP, Lei Orçamentária de São Paulo) } \\
\hline
\end{tabular}

Conforme ilustrado na Tabela 2, é possível constatar que $28 \%$ da receita orçada era proveniente da expectativa de arrecadação com as rendas das estradas, sendo os $72 \%$ restantes advindos dos demais impostos, com destaque para os valores orçados correspondentes aos dízimos e pela cobrança sobre a passagem dos animais no registro do Rio Negro. Excluindo-se dos cálculos a receita proveniente das estradas, o primeiro representa pouco mais de $14 \%$ da receita orçada e o segundo aproximadamente $38 \%$.

\footnotetext{
${ }^{35}$ Optamos por utilizar a taxa de câmbio indicada no texto "Brasil: breves comentários sobre algumas séries referente à taxa de câmbio". Nele os autores indicam a série de taxa de câmbio implícita na praça do Rio de Janeiro, publicada no terceiro volume da série de estatísticas retrospectivas do IBGE. (Cf. NOZOE et alii, 2004).
} 


\section{Tabela 2 - Lei Orcamentária no 17, de 11 de abril de 1835}

(Ano financeiro de $1^{\circ}$ de julho de 1835 a 30 de junho de 1836)

\begin{tabular}{lr}
\hline \multicolumn{1}{c}{ Receitas } & $25: 000 \$ 000$ \\
\hline $1^{\circ}$ - Importância dos Dízimos & $5: 400 \$ 000$ \\
$2^{\circ}$ - Dita da imposição de 20 por cento no consumo das aguardentes de produção brasileira & $19: 600 \$ 000$ \\
$3^{\circ}$ - Dita do novo imposto, ou subsídio voluntário & $13: 400 \$ 000$ \\
$4^{\circ}$ - Dita da decima dos prédios urbanos & $600 \$ 000$ \\
$5^{\circ}$ - Dita de foros, e arrendamentos de próprios nacionais & $14: 000 \$ 000$ \\
$6^{\circ}$ - Dita do imposto de $1 \$ 600$ rs por cada rês que se corta, na forma da lei provincial respectiva, e do de 320rs & $9: 000 \$ 000$ \\
de subsídio literário & $5: 400 \$ 000$ \\
$7^{\circ}$ - Dita da meia sisa da venda de quaisquer escravos & $2: 000 \$ 000$ \\
$8^{\circ}$ - Dita da decima dos legados, e heranças & $100 \$ 000$ \\
$9^{\circ}$ - Dita dos novos e velhos direitos dos títulos expedidos pelas autoridades provinciais, inclusive a taxa que por \\
este título pagão as fianças criminais, a qual fica substituída pela taxa de 2 por cento da avaliação delas \\
$10^{\circ}$ - Dita de emolumentos do Secretário do Governo & $400 \$ 00$ \\
$11^{\circ}$ - Dita dos despachos das embarcações & $5: 000 \$ 000$ \\
$12^{\circ}$ - Dita da contribuição para Guarapuava & $66: 000 \$ 000$ \\
$13^{\circ}$ - Dita dos animais no Registro do Rio Negro & $400 \$ 00$ \\
$14^{\circ}$ - Dita do produto das multas sobre o Mestre de barcos & $9: 200 \$ 00$ \\
$15^{\circ}$ - Dita das passagens de rios & $\mathbf{1 7 5 : 5 0 0 \$ 0 0 0}$ \\
\hline Soma & $\mathbf{6 8 : 2 0 0} \$ \mathbf{0 0}$ \\
\hline Renda das Estradas & $\mathbf{2 4 3 : 7 0 0 \$ 0 0 0}$ \\
\hline Soma total &
\end{tabular}

Com o objetivo de demonstrar o avanço dos dízimos no período que compreende 1835 a 1839, anos intermediários entre a primeira e a segunda Leis Orçamentárias coletadas, a Tabela 3 apresenta a expectativa arrecadatória com este tributo na segunda metade dos 1830. No período de 05 anos ocorreu uma variação de quase $255 \%$ no valor orçado dos dízimos, saltando de $£ 04.088$ - valor orçado em 1835 - para $£ 14.487$ - valor orçado em 1839.

$\underline{\text { Tabela } 3 \text { - Evolução dos Direitos de Saída. São Paulo, (1835-1839) }}$

\begin{tabular}{cccc}
\hline Lei & $\begin{array}{c}\text { Dízimos - Direitos de Saída } \\
\text { Receita Orçada } \\
\text { (valores nominais) }\end{array}$ & $\begin{array}{c}\text { Dízimos - Direitos de Saída } \\
\text { Receita Orçada } \\
\text { (valores em libras esterlinas) }\end{array}$ & $\begin{array}{c}\text { Variação \% em relação } \\
\text { ao período anterior } \\
\text { (em libras esterlinas) }\end{array}$ \\
\hline $\mathrm{N}^{\mathrm{o}} 17$, de 11/04/1835 & $25: 000 \$ 000$ & 4.088 & - \\
$\mathrm{N}^{\mathrm{o}} 40$, de 18/03/1836 & $25: 000 \$ 000$ & 4.004 & $-2,05 \%$ \\
$\mathrm{~N}^{\mathrm{o}} 14$, de 10/03/1837 & $60: 000 \$ 000$ & 7.392 & $84,62 \%$ \\
$\mathrm{~N}^{\mathrm{o}} 22$, de 30/03/1838 & $80: 000 \$ 000$ & 9.351 & $26,50 \%$ \\
$\mathrm{~N}^{\mathrm{o}} 11$, de $23 / 03 / 1839$ & $110: 000 \$ 000$ & 14.487 & $54,92 \%$ \\
\hline
\end{tabular}

Procurando compreender os movimentos existentes entre a expectativa arrecadatória com os dízimos, suas alíquotas e demais determinações estabelecidas em leis, somaremos às análises as deliberações acerca da taxa, base de cálculo e fato gerador do imposto. Para tanto, nos utilizaremos do rico e minucioso trabalho elaborado por Viviane Tessitore. A autora, em sua pesquisa sobre As Fontes de Riqueza Pública - Tributos e Administração 
Tributária na Província de São Paulo, (1832-1892), efetua o levantamento acerca do histórico e características fiscais dos impostos recolhidos em terras paulistas. Deste modo, a abordagem descritiva de Tessitore em muito vem a contribuir com nossa pesquisa quantitativa acerca da importância dos dízimos/direitos de saída paulistas.

O regulamento de 25 de junho de 1836 fixou a seguinte tabela:

- $3 \%$ sobre o valor do café serra de Santos acima;

- 4\% sobre o valor do café serra de Santos abaixo;

- 5\% sobre o valor do açúcar, algodão, tabaco, fumo, gado bovino e cavalos;

- 5\% sobre o valor de qualquer produto de lavoura e criação havido na Província manufaturado;

- $10 \%$ sobre o valor de qualquer produto de lavoura e criação havido na Província não manufaturado.

Seriam considerados produtos havidos na Província os que apresentassem, em 24 horas após sua chegada, guias qualificadas comprovadora de outra origem, para serem verificadas no momento de sua saída de São Paulo. A base para a cobrança seria a qualidade e o preço corrente do gênero, estabelecido por dois corretores ou negociantes de reconhecida probidade.

Em aditamento ao regulamento de 25 de junho de 1836, o regulamento de 1 de julho de 1837 estabelecia:

- 5\% sobre o valor do café, açúcar, algodão, tabaco, fumo, gado bovino e cavalar e qualquer produto de lavoura ou criação manufaturados (incluídos nos $7 \%$ do imposto geral, se os gêneros saíssem do Império);

- $10 \%$ sobre o valor de qualquer produto de lavoura e criação havido na Província não manufaturados (5\% se saísse fora do Império). Buscava-se, assim, fazer cessar o "muito clamor" dos exportadores contra a elevação ao dobro da taxa sobre o açúcar e o café, solucionando dúvidas e prevenindo fraudes.

O regulamento de 1 de junho de 1838 determinou que, para o pagamento do imposto, o café fosse dividido em bom (média do preço do de $1^{\mathrm{a}}$ e $2^{\mathrm{a}}$ categoria) e escolha. (TESSITORE, 1995, p. 154)

Seguindo as análises, por meio da Tabela 4 pode-se observar detalhadamente a Lei Orçamentária de 1840. Nesta lei ocorre a alteração de nomenclatura do imposto, os antigos dízimos passam a ser classificados como direitos de saída. Se comparada à Lei Orçamentária de 1835 - e considerando-se para isso os valores em libras esterlinas - o total da receita orçada para o exercício financeiro de 1840-1841 elevou-se $18,57 \%$. Os direitos de saída e o direito dos animais que passam pelo Rio Negro continuaram a constituir as principais fontes da receita orçada. Todavia, em comparação com o orçamento de 1835, os direitos de saída passaram de uma participação de pouco mais de 14\% para aproximadamente 35\% neste momento. Desta forma, é possível constatar que no período de meia década os direitos de saída passam a ter maior importância dentre as 
fontes de renda orçada, tomando o lugar de vanguarda que antes era atribuído aos direitos de passagem de animais pelo Rio Negro.

A representatividade crescente que os direitos de saída passam a assumir no orçamento provincial a partir desta Lei Orçamentária será mantida e até elevada nas leis vindouras, sendo esse o resultado da importância, também crescente, do café na economia paulista.

Tabela 4 - Lei Orcamentária $\mathbf{n}^{\circ} 17$, de 26 de marco de 1840 (Ano financeiro de $1^{\circ}$ de julho de 1840 a 30 de junho de 1841)

\begin{tabular}{lr}
\hline \multicolumn{1}{c}{ Receitas } & $100: 000 \$ 00$ \\
\hline $1^{\circ}$ - Direitos de saída da Província denominados dízimos & $16: 000 \$ 000$ \\
$2^{\circ}$ - Imposto sobre as aguardentes nacionais e estrangeiras & $10: 000 \$ 000$ \\
$3^{\circ}$ - Dito sobre os armazéns, tabernas e botequins de serra acima & $8: 000 \$ 000$ \\
$4^{\circ}$ - Novo imposto sobre os animais em Sorocaba & $6: 200 \$ 000$ \\
$5^{\circ}$ - Contribuição para Guarapuava & $15: 000 \$ 000$ \\
$6^{\circ}$ - Imposto de $\$ 600$ rs das reses que se cortam e 320 rs de subsídio literário & $15: 000 \$ 000$ \\
$7^{\circ}$ - Meia sisa da venda de escravos & $8: 000 \$ 000$ \\
$8^{\circ}$ - Décima dos legados e heranças & $2: 000 \$ 000$ \\
$9^{\circ}$ - Novos e velhos direitos provinciais & $80: 738 \$ 000$ \\
$10^{\circ}$ - Direitos dos animais que passam pelo Rio Negro & $150 \$ 000$ \\
$11^{\circ}$ - Emolumentos do lugar de secretário do Governo & $400 \$ 000$ \\
$12^{\circ}$ - Despacho das embarcações & $200 \$ 000$ \\
$13^{\circ}$ - Imposto sobre as casas de leilão e modas & $24: 800 \$ 000$ \\
$14^{\circ}$ - Cobrança da metade da dívida ativa provincial anterior ao 1 de julho de 1836, e toda dívida ativa dessa & $160 \$ 000$ \\
data em diante & $4: 000 \$ 000$ \\
$15^{\circ}$ - Tipografia provincial & $200 \$ 00$ \\
$16^{\circ}$ - Juros das apólices compradas por conta do cofre provincial vencidos no corrente ano & $\mathbf{2 9 0 : 8 4 8 \$ 0 0 0}$ \\
$17^{\circ}$ - Renda eventual, multa sobre os contribuintes morosos e prêmio dos depósitos públicos & $\mathbf{7 4 : 8 0 0 \$ 0 0 0}$ \\
\hline Soma & $\mathbf{3 6 5 : 6 4 8 \$ 0 0 0}$ \\
\hline Renda das Estradas & Fonte: (ALESP, Lei Orçamentária de São Paulo)
\end{tabular}

A demonstração da trajetória ascendente dos valores orçados dos direitos de saída, no decorrer da década de 1840, encontra-se na Tabela 5. Analisando-se as cifras apresentadas, é possível perceber que o comportamento dos antigos dízimos na receita orçada no período 1840-1849 apresenta uma tendência crescente, alcançando tal variação, se calculada com base nos valores em libras esterlinas, quase $27 \%$. Em valores nominais a elevação é ainda mais significativa, alcançando os $52 \%$.

Tabela 5 - Evolucão dos Direitos de Saída. São Paulo, (1840-1849)

\begin{tabular}{|c|c|c|c|}
\hline Lei & $\begin{array}{c}\text { Dízimos - Direitos de Saída } \\
\text { Receita Orçada } \\
\text { (valores nominais) }\end{array}$ & $\begin{array}{c}\text { Dízimos - Direitos de Saída } \\
\text { Receita Orçada } \\
\text { (valores em libras esterlinas) }\end{array}$ & $\begin{array}{c}\text { Variação \% em relação } \\
\text { ao período anterior } \\
\text { (em libras esterlinas })\end{array}$ \\
\hline $\mathrm{N}^{\mathrm{o}} 17$, de $26 / 03 / 1840$ & $100: 000 \$ 000$ & 12.920 & $-10,82 \%$ \\
\hline $\mathrm{N}^{\mathrm{o}} 25$, de $23 / 03 / 1841$ & $140: 000 \$ 000$ & 17.681 & $36,85 \%$ \\
\hline $\mathrm{N}^{\mathrm{o}} 40$, de $23 / 03 / 1844$ & $130: 000 \$ 000$ & 13.650 & $-22,80 \%$ \\
\hline $\mathrm{N}^{\mathrm{o}} 10$, de $19 / 02 / 1845$ & $104: 000 \$ 000$ & 11.024 & $-19,24 \%$ \\
\hline $\mathrm{N}^{\mathrm{o}} 35$, de $16 / 03 / 1846$ & $115: 000 \$ 000$ & 12.903 & $17,04 \%$ \\
\hline
\end{tabular}


Retomando as considerações de Tessitore, no período em pauta observamos as seguintes deliberações acerca dos direitos de saída:

A lei $\mathrm{n}^{\circ} 2$, de 19 de fevereiro de 1840 , reeditou a tabela, dirimindo as dúvidas ainda existentes:

- $10 \%$ sobre os gêneros não manufaturados exportados da Província de São Paulo para outras Províncias do Império;

- 5\% sobre as madeiras lavradas ou não, a aguardente e outros gêneros manufaturados exportados da Província de São Paulo para outras Províncias do Império.

A lei $\mathrm{n}^{\mathrm{o}} 2$, de 19 de fevereiro de 1840 , colocou claramente que estavam isentos os gêneros exportados para fora do Império. O Presidente da Província afirmava, em seu Relatório de 15 de fevereiro de 1855, que essa medida teve como objetivo estimular o comércio exterior da Província, mas o que se conseguiu foi a diminuição tremenda da receita, pois "o preço dos gêneros no mercado de Santos está sujeito a leis econômicas, que não podem ser contrariadas ou combatidas por uma só medida fiscal".

A lei $\mathrm{n}^{\circ} 17$, de 26 de março de 1840 , determinava que continuassem os descontos das conduções no valor do imposto, como de costume, para que não fossem prejudicados os produtores que morassem mais distantes dos portos. Entretanto, a lei $n^{\circ} 30$, de 3 de abril de 1866 determinou que não se concedesse mais descontos dos importes e das conduções.

A lei ${ }^{\circ} 10$, de 19 de fevereiro de 1845, no seu art. 13, reduziu as taxas de $5 \%$ para $4 \%$ e de $10 \%$ para $8 \%$ [Vide determinações da lei $n^{\circ} 2$, de 19 de fevereiro de 1840, especificada acima - C.S.].

Em ofício ao Inspetor do Tesouro Provincial, de 5 de junho de 1848, o Presidente da Província determinava que o preço do café que serviria de base para a cobrança dos direitos de saída fosse \$200 menor que o da Mesa de Rendas do Rio de Janeiro. Atendia, assim, à representação de vários fazendeiros da Vila do Bananal, na qual ponderavam que o café paulista seria inferior ao carioca, não tendo dado resultado a medida anterior do Governo para diminuir seus prejuízos. (TESSITORE, 1995, pp. 154-157)

Como mencionado anteriormente, com o passar dos anos a evolução da expectativa de arrecadação paulista continua sua trajetória crescente. Comparando-se os valores orçados de 1840 com aqueles presentes na Lei Orçamentária de 1850, é possível perceber que em libras esterlinas a receita orçada cresceu cerca de $23 \%$. Em valores nominais, as diversas fontes de renda são apresentadas na Tabela 6. 
$\underline{\text { Tabela } 6 \text { - Lei Orcamentária } n^{0} 24 \text {, de } 02 \text { de julho de } 1850}$

(Ano financeiro de $1^{\circ}$ de julho de 1850 a 30 de junho de 1851)

\begin{tabular}{lr}
\hline & Receitas \\
\hline $1^{\circ}$ - Direitos de saída sobre os gêneros da Província & $150: 000 \$ 000$ \\
$2^{\circ}$ - Novos e velhos direitos provinciais & $1: 000 \$ 000$ \\
$3^{\circ}$ - Décima de legados e heranças & $30: 000 \$ 000$ \\
$4^{\circ}$ - Décima urbana dos prédios dos conventos de frades & $700 \$ 000$ \\
$5^{\circ}$ - Direitos dos animais nos registros do Rio Negro e Guarapuava & $80: 000 \$ 000$ \\
$6^{\circ}$ - Novo imposto dos animais em Sorocaba & $9: 000 \$ 000$ \\
$7^{\circ}$ - Contribuição para Guarapuava & $7: 000 \$ 000$ \\
$8^{\circ}$ - Emolumentos da secretaria do Governo & $600 \$ 000$ \\
$9^{\circ}$ - Despachos de embarcações & $900 \$ 000$ \\
$10^{\circ}$ - Imposto sobre casas de leilão e modas & $100 \$ 000$ \\
$11^{\circ}$ - Cobrança da dívida ativa provincial & $12: 000 \$ 00$ \\
$12^{\circ}$ - Tipografia do Governo & $150 \$ 000$ \\
$13^{\circ}$ - Imposto de $1 \$ 600$ sobre as rezes, e 320 de subsídio literário & $23: 000 \$ 000$ \\
$14^{\circ}$ - Imposto sobre as aguardentes nacional e estrangeira & $18: 000 \$ 000$ \\
$15^{\circ}$ - Receita eventual & $4: 000 \$ 000$ \\
$16^{\circ}$ - Juros das apólices da dívida pública & $10: 500 \$ 000$ \\
$17^{\circ}$ - Meia sisa de escravos & $18: 000 \$ 000$ \\
\hline Soma & $\mathbf{3 6 4 : 9 5 0 \$ 0 0 0}$ \\
\hline Renda das Estradas & $\mathbf{1 2 1 : 5 0 0 \$ 0 0 0}$ \\
\hline Soma total & $\mathbf{4 8 6 : 4 5 0 \$ 0 0 0}$ \\
\hline
\end{tabular}

Os direitos de saída e os direitos dos animais nos registros do Rio Negro, e agora também Guarapuava, permaneceram como as principais fontes de renda da Província, representando esses, se somados, $63 \%$ da receita orçada total.

Fazendo uma análise retrospectiva, num período de quinze anos o valor orçado dos direitos de saída saltou, em termos nominais, de 25:000\$000 para 150:000\$000 mil-réis, uma elevação calculada em 500\%. Em 1835, tais impostos representavam aproximadamente $14 \%$ da receita orçada, excluindo-se dos cálculos a renda das estradas. No ano de 1850, essas fontes de renda já representavam $41 \%$ do orçamento. Em síntese, no período de uma década e meia, apenas um imposto passou a representar quase a metade da receita orçada, se descontada a renda das estradas.

Procurando entender este movimento, e relacionando-o com a realidade econômica da Província, constatamos que "a partir de 1846-1847, a exportação do açúcar tende a diminuir e a do café a aumentar (...) Depois de 1850-1851, temos uma exportação do café sempre maior que a do açúcar”. (PETRONE, 1968, p. 162) Contudo, em libras esterlinas, em 1831 o valor exportado de café já ultrapassa o de açúcar, mantendo-se, a partir daí, o café como principal produto na pauta de exportações do Império. Tais aspectos econômicos nos auxiliam no entendimento da crescente importância dos direitos de saída para as receitas provinciais. 
Desta maneira, a Tabela 7 apresenta a evolução dos valores orçados relativos aos direitos de saída, nos anos de 1850. Como pode ser observado, nesta década o aumento da participação dos direitos de saída na receita orçada é significativo, apresentando uma variação - em termos nominais, - de aproximadamente $127 \%$ no período de dez anos. Considerando tal comportamento nos valores em libras esterlinas, o crescimento é de aproximadamente $97 \%$.

Tabela 7 - Evolução dos Direitos de Saída. São Paulo, (1850-1859)

\begin{tabular}{|c|c|c|c|}
\hline Lei & $\begin{array}{c}\text { Dízimos - Direitos de Saída } \\
\text { Receita Orçada } \\
\text { (valores nominais) }\end{array}$ & $\begin{array}{l}\text { Dízimos - Direitos de Saída } \\
\text { Receita Orçada } \\
\text { (valores em libras esterlinas) }\end{array}$ & $\begin{array}{l}\text { Variação \% em relação } \\
\text { ao período anterior } \\
\text { (em libras esterlinas })\end{array}$ \\
\hline $\mathrm{N}^{\mathrm{o}} 24$, de $02 / 07 / 1850$ & $150: 000 \$ 000$ & 17.971 & $9,68 \%$ \\
\hline $\mathrm{N}^{\mathrm{o}} 10$, de $07 / 05 / 1851$ & $160: 000 \$ 000$ & 19.408 & $8,00 \%$ \\
\hline $\mathrm{N}^{\mathrm{o}} 14$, de $19 / 07 / 1852$ & $180: 000 \$ 000$ & 20.574 & $6,01 \%$ \\
\hline $\mathrm{N}^{\mathrm{o}} 18$, de $02 / 05 / 1853$ & $195: 000 \$ 000$ & 23.145 & $12,50 \%$ \\
\hline $\mathrm{N}^{\mathrm{o}} 30$, de $10 / 05 / 1854$ & 200:000\$000 & 23.020 & $-0,54 \%$ \\
\hline $\mathrm{N}^{\mathrm{o}} 31$, de $25 / 04 / 1855$ & 280:000\$000 & 32.143 & $39,63 \%$ \\
\hline $\mathrm{N}^{\mathrm{o}} 31$, de $07 / 05 / 1856$ & $320: 000 \$ 000$ & 36.735 & $14,29 \%$ \\
\hline $\mathrm{N}^{\mathrm{o}} 47$, de $07 / 05 / 1857$ & $360: 000 \$ 000$ & 39.885 & $8,57 \%$ \\
\hline $\mathrm{N}^{\mathrm{o}} 39$, de $04 / 05 / 1858$ & 400:000\$000 & 42.508 & $6,58 \%$ \\
\hline $\mathrm{N}^{\mathrm{o}} 27$, de $11 / 05 / 1859$ & 340:000\$000 & 35.494 & $-16,50 \%$ \\
\hline
\end{tabular}

Seguindo nossas análises, consideraremos agora a Lei Orçamentária de 1861. Com base na Tabela 8 , podemos observar que os direitos de saída continuam representando a principal expectativa de arrecadação da Província, agora compondo $48 \%$ da receita orçada. Contudo, imprescindível salientar que se em 1850 esperava-se arrecadar 150:000\$000 com essa fonte de recursos, a Lei Orçamentária de 1861 prevê uma arrecadação na ordem de 400:000\$000, ou seja, um acréscimo em valores nominais calculado em $167 \%$ com relação ao período anterior; e de $1.500 \%$ se comparado com o valor orçado em 1835. Ademais, no ano de 1853 a Província de São Paulo perdeu parte de seu território. Deste modo, esta alteração também foi sentida nas fontes de receitas fiscais, uma vez que os direitos dos animais nos registros do Rio Negro e Guarapuava passaram a compor a fonte tributária da nascente Província do Paraná.

Tabela 8 - Lei Orcamentária $n^{0} 16$, de 03 de agosto de 1861 (Ano financeiro de $1^{\circ}$ de julho de 1861 a 30 de junho de 1862)

\begin{tabular}{lr}
\hline & Receitas \\
\hline $1^{\circ}$ - Direitos de saída & $400: 000 \$ 000$ \\
$2^{\circ}-$ Meia sisa de escravos & $61: 549 \$ 093$ \\
$3^{\circ}$ - Novos e velhos direitos & $2: 537 \$ 672$ \\
$4^{\circ}$ - Decima de legados e heranças & $147: 000 \$ 000$ \\
$5^{\circ}$ - Ditas de casas de conventos de frades & $1: 569 \$ 194$
\end{tabular}


Durante a década de 1860 os direitos de saída continuaram a mostrar trajetória ascendente. Algumas variações negativas são observadas no período, mas de modo geral a tendência é claramente crescente. A Tabela 9 demonstra tal evolução, tanto em valores nominais como em libras esterlinas. Em valores nominais, os montantes orçados ascenderam cerca de $75 \%$; em libras esterlinas os totais orçados se elevaram em quase $29 \%$.

Tabela 9 - Evolucão dos Direitos de Saída. São Paulo, (1861-1869)

\begin{tabular}{|c|c|c|c|}
\hline Lei & $\begin{array}{c}\text { Dízimos - Direitos de Saída } \\
\text { Receita Orçada } \\
\text { (valores nominais) } \\
\end{array}$ & $\begin{array}{c}\text { Dízimos - Direitos de Saída } \\
\text { Receita Orçada } \\
\text { (valores em libras esterlinas) }\end{array}$ & $\begin{array}{c}\text { Variação \% em relação } \\
\text { ao período anterior } \\
\text { (em libras esterlinas) }\end{array}$ \\
\hline $\mathrm{N}^{\circ} 16$, de $03 / 08 / 1861$ & 400:000\$000 & 42.599 & $20,02 \%$ \\
\hline $\mathrm{N}^{\circ} 08$, de $19 / 05 / 1862$ & 450:000\$000 & 49.315 & $15,77 \%$ \\
\hline $\mathrm{N}^{\circ} 16$, de $21 / 04 / 1863$ & 450:000\$000 & 51.090 & $3,60 \%$ \\
\hline $\mathrm{N}^{\circ} 30$, de $26 / 04 / 1864$ & 540:000\$000 & 60.228 & $17,89 \%$ \\
\hline $\mathrm{N}^{\circ} 77$, de $24 / 04 / 1865$ & $544: 489 \$ 000$ & 56.747 & $-5,78 \%$ \\
\hline $\mathrm{N}^{\circ} 54$, de $20 / 04 / 1866$ & 650:000\$000 & 65.268 & $15,02 \%$ \\
\hline $\mathrm{N}^{\circ} 16$, de $10 / 07 / 1867$ & 650:000\$000 & 60.782 & $-6,87 \%$ \\
\hline $\mathrm{N}^{\circ} 57$, de $18 / 04 / 1868$ & 700:000\$000 & 48.658 & $-19,95 \%$ \\
\hline $\mathrm{N}^{\mathrm{o}} 29$, de $07 / 07 / 1869$ & 700:000\$000 & 54.898 & $12,82 \%$ \\
\hline
\end{tabular}

Novamente utilizando-nos das contribuições dos estudos de Tessitore, analisemos as deliberações direcionadas aos direitos de saída na década de 1860:

A lei $\mathrm{n}^{\circ} 30$, de 3 de abril de 1866, fixou uma nova tabela para o imposto: - 7,5\% sobre o valor dos gêneros não manufaturados;

- 3,5\% sobre o valor dos gêneros manufaturados de produção ou exportação da Província;

- $6 \%$ sobre o valor do algodão em rama;

- $3 \%$ sobre o valor do algodão manufaturado;

- 4\% sobre o valor dos gêneros que fossem exportados dos Portos da Província para o exterior, taxa confirmada pela lei $\mathrm{n}^{\circ} 16$, de 10 de junho de 1867, art. 14.

A lei $\mathrm{n}^{\circ} 57$, de 18 de abril de 1868 , restabeleceu as taxas fixadas pela lei $\mathrm{n}^{\circ}$ 10, de 19 de fevereiro de 1845 , no seu art. 13: 
- $4 \%$ sobre o dos gêneros de produção e exportação da Província manufaturados;

- $8 \%$ sobre o valor dos não manufaturados.

O regulamento $\mathrm{n}^{\circ}$ 9, de 22 de abril de 1868, para os direitos de saída cobrados pela Mesa de Rendas de Santos, manteve as disposições anteriores ainda em vigor, e determinou que o valor dos gêneros fosse estabelecido em pauta semanal.

A lei no 29 , de 7 de julho de 1869, art. 48, fixou a taxa do imposto em:

- 3\% sobre o valor dos gêneros de exportação da Província, qualquer que fosse sua natureza ou qualidade, sem desconto de condução;

- taxa elevada a 4\% pelo art. 48 da lei $\mathrm{n}^{\circ}$ 93, de 21 de abril de 1870. (TESSITORE, 1995, pp. 154-155)

Na Lei Orçamentária referente ao ano financeiro de 1870-1871, demonstrada na Tabela 10, é possível observar que, se comparado à Lei Orçamentária de 1861, o valor estimado da receita paulista deu novo salto, passando de $£ 118.905$ para $£ 224.356$, numa elevação calculada em aproximadamente $88 \%$.

A principal fonte de renda continua a ser os chamados direitos de saída, sendo os valores orçados substancialmente mais elevados do que no período anterior. Em termos nominais, os direitos de saída alcançaram a cifra de 1.720:000\$000 mil-réis, representando consideráveis $83 \%$ da receita orçada. Novamente, se compararmos a evolução deste imposto desde o início do período, em 1835, vemos uma elevação de $6.780 \%$ no decorrer de 35 anos. Quando comparado ao valor informado na Lei Orçamentária de 1861, também se nota um aumento substancial, na ordem de $330 \%$.

Tabela 10 - Lei Orcamentária n $\mathrm{n}^{\circ}$ 93, de 21 de abril de 1870

(Ano financeiro de $1^{\circ}$ de julho de 1870 a 30 de junho de 1871)

\begin{tabular}{|c|c|}
\hline \multicolumn{2}{|c|}{ Receitas } \\
\hline $1^{\circ}$ - Direitos de saídas dos gêneros da Província & 1.720:000\$000 \\
\hline $2^{\circ}$ - Meia sisa de escravos & 170:000\$000 \\
\hline $3^{\circ}$ - Decima de legados e heranças & $80: 000 \$ 000$ \\
\hline $4^{\circ}$ - Decimas de casas de Conventos & 2:000\$000 \\
\hline $5^{\circ}$ - Novo imposto de animais em Sorocaba & 17:000\$000 \\
\hline $6^{\circ}$ - Despacho de embarcações & $1: 500 \$ 000$ \\
\hline $7^{0}$ - Imposto sobre casas de modas e leilões & $800 \$ 000$ \\
\hline $8^{\circ}$ - Imposto sobre seges e mais veículos & $1: 200 \$ 000$ \\
\hline $9^{\circ}$ - Cobrança da dívida ativa & $5: 000 \$ 000$ \\
\hline $10^{\circ}$ - Imposto sobre escravos saídos por mar & 2:000\$000 \\
\hline $11^{\circ}$ - Rendimento da ponte de embarque & 40:000\$000 \\
\hline $12^{\circ}$ - Rendimento da Casa de Correção & $10: 000 \$ 000$ \\
\hline $13^{\circ}-$ Emolumentos & $10: 000 \$ 000$ \\
\hline $14^{\circ}$ - Imposto de escravo que não pagarão meia sisa & $500 \$ 000$ \\
\hline $15^{\circ}$ - Imposto sobre escravos de Conventos & $500 \$ 000$ \\
\hline $16^{\circ}$ - Indenização e multas & $4: 500 \$ 000$ \\
\hline $17^{\circ}$ - Eventual & $5: 000 \$ 000$ \\
\hline $18^{\circ}$ - Taxa das Barreiras & $360: 000 \$ 000$ \\
\hline Soma & 2.430:000\$000 \\
\hline
\end{tabular}


A representatividade de $83 \%$ dos direitos de saída no cômputo total sem dúvida constitui uma exceção considerando-se os valores encontrados nas demais Leis Orçamentárias. Uma hipótese para este fato seria o aumento na produção e exportação do café possibilitado pelo avanço da ferrovia. Com o início das operações da linha "SantosJundiaí", em 1867, o transporte e escoamento do café pelo porto de Santos foi consideravelmente facilitado. Além disso, adiante será possível constatar que no ano de 1868 a quantia arrecadada com os direitos de saída representou quase o dobro do valor que se esperava recolher. É possível que este número tenha exercido influência sobre as Leis Orçamentárias seguintes.

Prosseguindo, a Tabela 11 ilustra a evolução dos valores orçados relativos aos direitos de saída nos anos de 1870.

Tabela 11 - Evolucão dos Direitos de Saída. São Paulo, (1870-1877)

\begin{tabular}{|c|c|c|c|}
\hline Lei & $\begin{array}{c}\text { Dízimos - Direitos de Saída } \\
\text { Receita Orçada } \\
\text { (valores nominais) } \\
\end{array}$ & $\begin{array}{c}\text { Dízimos - Direitos de Saída } \\
\text { Receita Orçada } \\
\text { (valores em libras } \\
\text { esterlinas) } \\
\end{array}$ & $\begin{array}{c}\text { Variação \% em } \\
\text { relação ao período } \\
\text { anterior } \\
\text { (em libras esterlinas) }\end{array}$ \\
\hline $\mathrm{N}^{\mathrm{o}} 93$, de $21 / 04 / 1870$ & 1.720:000\$000 & 158.803 & $189,27 \%$ \\
\hline $\mathrm{N}^{\mathrm{o}} 45$, de $01 / 04 / 1871$ & $760: 000 \$ 000$ & 76.076 & $-52,09 \%$ \\
\hline $\mathrm{N}^{\mathrm{o}} 73$, de $26 / 04 / 1872$ & $940: 783 \$ 000$ & 98.029 & $28,86 \%$ \\
\hline $\mathrm{N}^{\mathrm{o}} 91$, de $25 / 04 / 1873$ & $1.160: 649 \$ 000$ & 121.229 & $23,67 \%$ \\
\hline $\mathrm{N}^{\mathrm{o}} 52$, de $24 / 04 / 1874$ & $1.892: 768 \$ 431$ & 203.283 & $67,69 \%$ \\
\hline $\mathrm{N}^{\mathrm{o}} 10$, de $07 / 07 / 1875$ & $1.237: 620 \$ 000$ & 142.419 & $-29,94 \%$ \\
\hline No 89, de $13 / 04 / 1876$ & $1.434: 848 \$ 000$ & 152.239 & $6,90 \%$ \\
\hline $\mathrm{N}^{\mathrm{o}} 22$, de $05 / 05 / 1877$ & $1.465: 368 \$ 000$ & 150.557 & $-1,10 \%$ \\
\hline
\end{tabular}

Na década de 1870, as seguintes deliberações legais são observadas:

Pela lei $\mathrm{n}^{\circ} 45$, de 1 de abril de 1871 , reduziu a taxa sobre o algodão a $2 \%$, elevada a $4 \%$ pela lei $\mathrm{n}^{\circ} 91$, de 5 de maio de 1873 .

$\mathrm{O}$ art. 1 das disposições permanentes da lei $\mathrm{n}^{\circ}$ 52, de 24 de abril de 1874 , reduziu a $2 \%$ a taxa sobre o arroz pilado, elevada novamente a $4 \%$ pelo art. 6 das disposições permanentes da lei $\mathrm{n}^{\circ} 156$, de 29 de abril de 1880 , reduzida ainda uma vez a $2 \%$ pelo art. 37 da lei $n^{\circ} 86-\mathrm{A}$, de 25 de junho de 1881. Sua taxa foi igualada à do café pelo art. 11 da lei $\mathrm{n}^{\circ} 55$, de 22 de março de 1888.

$\mathrm{O}$ art. 4 das disposições permanentes da lei $\mathrm{n}^{\circ} 22$, de 5 de maio de 1877 , aumentou a taxa sobre o café para $4,5 \%$, reduzida aos $4 \%$ anteriores pela lei $\mathrm{n}^{\circ} 10$, de 30 de março de 1878, mantida em 1881.

O café que os lavradores da Província remetessem à Exposição de Paris, por intermédio de sua Comissão em Campinas foi isento dos direitos pela 
lei $\mathrm{n}^{\circ} 10$, de 30 de março de 1878 , devendo ser restituída a quantia já arrecadada. (TESSITORE, 1995, pp. 155-157)

A esta altura das análises e discussões acerca da importância e representatividade dos direitos de saída para os cofres provinciais, devemos evidenciar um importante movimento político vivenciado no período. No início da década de 1880 novas discussões relacionadas às repartições das rendas em geral e provincial fizeram-se sentir em solos brasileiros. Deste modo, 50 anos após o início destas questões, 1831, o Governo Imperial intentou intervir na arrecadação das cifras relativas aos direitos de saída. O Império, sob a alegação acerca dos riscos que estes impostos ofereciam à integridade do território, objetivou retirar das Províncias a competência tributária desta receita:

A importância dos direitos de saída fez, inclusive, com que o Governo Imperial oscilasse entre o reconhecimento da competência provincial para cobrá-lo e a contestação de sua constitucionalidade. A Comissão que, em 1881, reviu a classificação das rendas gerais, provinciais e municipais, por exemplo, julgou-os muito elevados e danosos, tanto economicamente, quanto politicamente, relacionando-os, como já o fizera com os impostos de importação, a riscos para a integridade do Estado e a unidade nacional. (TESSITORE, 1995, p. 153)

Para a felicidade e prosperidade de São Paulo, tais medidas não foram colocadas em prática. Os cofres provinciais poderiam continuar a contar com sua preciosa fonte de renda advinda dos direitos de saída. Deste modo, passemos aos dados apresentados na Tabela 12 referentes à Lei Orçamentária para o ano de 1880.

É possível observar que a Lei Orçamentária de 1880 estimou uma receita de 3.732:371\$176 mil-réis, uma elevação de aproximadamente 54\% em relação ao orçamento de 1870. Se considerarmos os valores em libras esterlinas, o aumento alcança porcentagem semelhante, calculada em aproximadamente $54,5 \%$.

$\underline{\text { Tabela } 12 \text { - Lei Orcamentária } \mathrm{n}^{0} \mathbf{1 5 6} \text {, de } 29 \text { de abril de } 1880}$

(Ano financeiro de $1^{\circ}$ de julho de 1880 a 30 de junho de 1881)

\begin{tabular}{lr}
\hline & Receitas \\
\hline $1^{\circ}$ - Direitos de saída & $1.700: 000 \$ 000$ \\
$2^{\circ}-$ Meia sisa de escravos & $200: 000 \$ 000$ \\
$3^{\circ}$ - Decima de legados e heranças & $236.082 \$ 537$ \\
$4^{\circ}-$ Decima de uso frutos & $47: 216 \$ 500$ \\
$5^{\circ}-$ Decima de casa de Conventos & $3: 248 \$ 264$ \\
$6^{\circ}-$ Novo imposto de animais & $5: 671 \$ 853$ \\
$7^{\circ}-$ Despacho de embarcações & $3: 853 \$ 050$ \\
$8^{\circ}-$ Rendimento da ponte de embarque & $69: 925 \$ 338$ \\
$9^{\circ}-$ Rendimento da penitenciária & $13: 611 \$ 248$ \\
$10^{\circ}$ - Emolumentos & $20: 000 \$ 000$ \\
$11^{\circ}$ - Indenizações e multas & $65: 161 \$ 944$ \\
$12^{\circ}-$ Eventuais & $5: 365 \$ 319$ \\
$13^{\circ}-$ Taxa das Barreiras & $98: 609 \$ 000$ \\
$14^{\circ}-$ Imposto de trânsito & $800: 000 \$ 000$
\end{tabular}


Como vinha sendo feito anteriormente, a Tabela 13 expõe os valores orçados dos direitos de saída para a década de 1880, sendo possível verificar uma elevação de quase $60 \%$ nos valores orçados em libra esterlina.

Tabela 13 - Evolucão dos Direitos de Saída. São Paulo, (1880-1889)

\begin{tabular}{|c|c|c|c|}
\hline Lei & $\begin{array}{c}\text { Dízimos - Direitos de Saída } \\
\text { Receita Orçada } \\
\text { (valores nominais) }\end{array}$ & $\begin{array}{c}\text { Dízimos - Direitos de Saída } \\
\text { Receita Orçada } \\
\text { (valores em libras esterlinas) }\end{array}$ & $\begin{array}{c}\text { Variação \% em relação } \\
\text { ao período anterior } \\
\text { (em libras esterlinas })\end{array}$ \\
\hline $\mathrm{N}^{\mathrm{o}} 156$, de $29 / 04 / 1880$ & $1.700: 000 \$ 000$ & 157.846 & $4,84 \%$ \\
\hline $\mathrm{N}^{\circ} 59$, de $25 / 04 / 1884$ & $1.665: 000 \$ 000$ & 143.522 & $-9,07 \%$ \\
\hline $\mathrm{N}^{\circ} 94$, de $20 / 04 / 1885$ & $1.850: 000 \$ 000$ & 143.211 & $-0,22 \%$ \\
\hline $\mathrm{N}^{\mathrm{o}} 124$, de $28 / 05 / 1886$ & 2.100:000\$000 & 163.373 & $14,08 \%$ \\
\hline $\mathrm{N}^{\circ} 95$, de $11 / 04 / 1887$ & $2.030: 000 \$ 000$ & 189.791 & $16,17 \%$ \\
\hline $\mathrm{N}^{\circ} 55$, de $22 / 03 / 1888$ & $2.418: 000 \$ 000$ & 254.392 & $34,04 \%$ \\
\hline $\mathrm{N}^{\mathrm{o}} 107$, de $09 / 04 / 1889$ & 2.300:000\$000 & 253.444 & $-0,37 \%$ \\
\hline
\end{tabular}

Retornando às determinações legais referentes aos direitos de saída, temos:

O café exportado em sacos de algodão da Província pagaria 3\%, conforme o art. 53 da lei $\mathrm{n}^{\circ} 59$, de 25 de abril de 1884 , disposição mantida pela lei $\mathrm{n}^{\circ}$ 94, de 20 de abril de 1885, art. 53.

O Governo Provincial estabeleceu, pela portaria $\mathrm{n}^{\circ} 231$, de 4 de junho de 1884 , uma tabela com taxas fixas - que variavam de $\$ 005$ a $9 \$ 600$ - para cobrança dos direitos de saída na Agência do Taboão da Coletoria de Cunha, conforme autorização dada pelo art. 61 da lei $n^{\circ} 59$, de 25 de abril de 1884. Essas disposições foram mantidas pelo art. 25 da lei $\mathrm{n}^{\circ}$ 94, de 20 de abril de 1885 .

$\mathrm{O}$ art. 12 das disposições permanentes da lei ${ }^{\circ}$ 107, de 9 de abril de 1889 , reduziu a $2 \%$ a taxa sobre os couros curtidos. (TESSITORE, 1995, p. 155)

Finalmente, chegamos ao estudo do último orçamento do Período Imperial. Com base nas informações apresentadas na Tabela 14, observamos que se comparada à Lei Orçamentária anterior houve um reajuste, em valores nominais da receita orçada, na

\footnotetext{
36 Valor replicado da lei orçamentária, o somatório não é exatamente igual por dificuldades em se transcrever os valores das demais rubricas.
} 
ordem de quase 36\%. Em libras esterlinas esse reajuste alcança aproximadamente $60 \%$. A razão para esse discrepante comportamento reside na valorização cambial sofrida pelo mil-réis frente a libra esterlina durante a década de 1880, sendo objetivo do Império a volta da paridade ideal estabelecida por lei no final da década de 1840, equivalente a uma taxa de câmbio de 26 pence/por mil-réis.

Tabela 14 - Lei Orcamentária no 107, de 09 de abril de 1889

(Ano financeiro de $1^{\circ}$ de julho de 1889 a 30 de junho de 1890)

\begin{tabular}{lr}
\hline & Receitas \\
\hline $1^{\circ}$ - Direitos de saída & $2.300: 000 \$ 000$ \\
$2^{\circ}$ - Taxa da ponte de embarque em Santos & $108: 300 \$ 000$ \\
$3^{\circ}$ - Despacho de embarcações & $13: 200 \$ 000$ \\
$4^{\circ}$ - Decima de legados e heranças & $215: 750 \$ 000$ \\
$5^{\circ}$ - Decima de uso-fruto & $15: 000 \$ 000$ \\
$6^{\circ}$ - Imposto de animais em Itararé e Sorocaba & $31: 280 \$ 000$ \\
$7^{\circ}-$ Taxa das barreiras & $16: 000 \$ 000$ \\
$8^{\circ}$ - Imposto de transporte ou de trânsito & $1.300: 000 \$ 000$ \\
$9^{\circ}$ - Dito sobre casas de leilão & $3: 220 \$ 000$ \\
$10^{\circ}$ - Dito sobre casas de modas & $1: 600 \$ 000$ \\
$11^{\circ}$ - Dito sobre seges e outros veículos & $4: 570 \$ 000$ \\
$12^{\circ}$ - Dito sobre capitalistas & $15: 000 \$ 000$ \\
$13^{\circ}$ - Dito sobre vendedores de bilhetes de loterias estranhas às da Província & $5: 200 \$ 000$ \\
$14^{\circ}$ - Dito Predial & $350: 000 \$ 000$ \\
$15^{\circ}$ - Dito sobre companhias equestres & $6: 000 \$ 000$ \\
$16^{\circ}$ - Emolumentos & $16: 200 \$ 000$ \\
$17^{\circ}$ - Novos direitos por diversas mercês & $19: 000 \$ 000$ \\
$18^{\circ}$ - Cobrança da dívida ativa & $70: 000 \$ 000$ \\
$19^{\circ}$ - Taxa adicional & $400: 000 \$ 000$ \\
$20^{\circ}$ - Indenizações & $58: 200 \$ 000$ \\
$21^{\circ}$ - Receita eventual, compreendendo as multas por infração de lei ou regulamento, e os dividendos das & $101: 200 \$ 000$ \\
ações da companhia Ituana & - \\
$22^{\circ}$ - Selo das patentes de oficiais da guarda nacional, arrecadado pela Fazenda Geral & $11: 400 \$ 000$ \\
$23^{\circ}$ - Rendimento dos estabelecimentos provinciais & $\mathbf{5 . 0 6 1 : 1 2 0 \$ 0 0 0}$ \\
\hline Soma & Fonte: (ALESP, Lei Orçamentária de São Paulo)
\end{tabular}

Deste modo, procuramos demonstrar o crescimento da representatividade dos direitos de saída no cômputo da receita provincial orçada em São Paulo. A fim de sumarizar os resultados alcançados com a análise das Leis Orçamentárias, elaboramos a Tabela 15.

Tabela 15 - Participação dos Direitos de Saída na Receita Orçada. $\underline{\text { São Paulo, (1835-1889) }}$

\begin{tabular}{cc}
\hline Ano & Participação na receita orçada \\
\hline 1835 & $14 \%$ \\
1840 & $35 \%$ \\
1850 & $41 \%$ \\
1861 & $48 \%$ \\
1870 & $83 \%$ \\
1880 & $46 \%$ \\
1889 & $45 \%$ \\
\hline Fonte: (ALESP, Lei Orçamentária de São Paulo)
\end{tabular}


Conforme evidenciado na Tabela 15, na Lei Orçamentária de 1835 os dízimos/direitos de saída respondiam por $14 \%$ do total orçado, desconsiderando-se os valores relativos à renda das estradas. Esses percentuais apresentam uma clara tendência de crescimento, exibindo um pico de $83 \%$ na Lei Orçamentária de 1870. Em libras esterlinas, a evolução da receita orçamentária total foi calculada em $1.300 \%$, se comparados os valores da receita total orçada - em libras esterlinas - entre 1835 e 1889. Todavia, o crescimento dos valores orçados relativos aos dízimos/direitos de saída - novamente convertidos em libras esterlinas - alcançou uma impressionante porcentagem de $6.000 \%$, conforme podemos observar no Gráfico 14.

\section{Gráfico 14 - Evolucão dos Direitos de Saída. São Paulo, (1835-1889)} (valores em libras esterlinas)

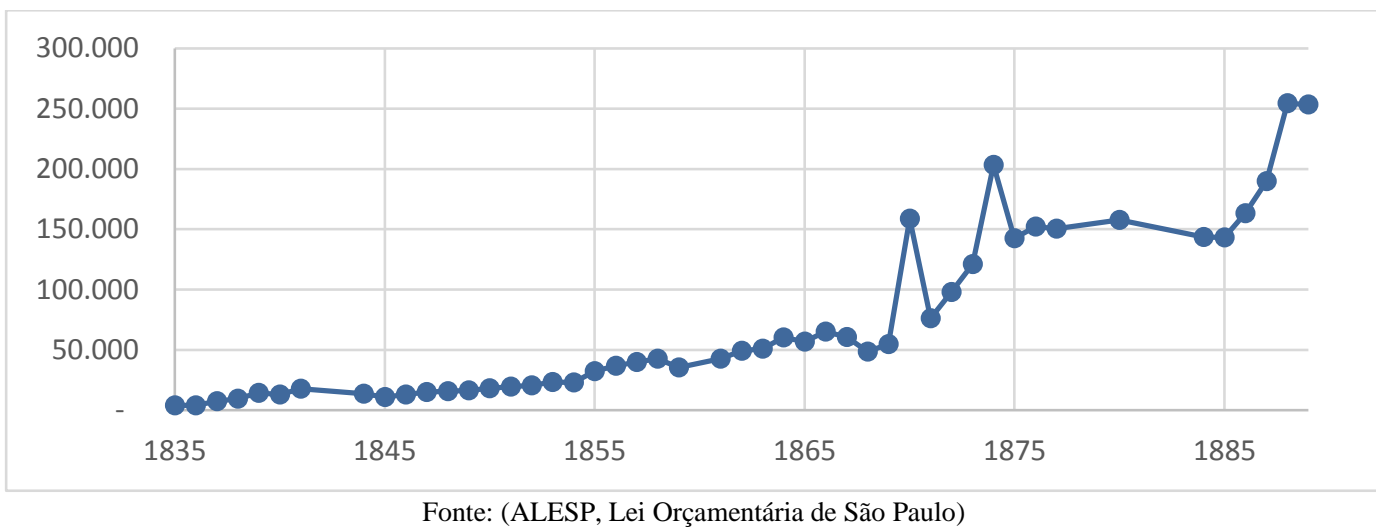

Lamentavelmente, as pesquisas localizaram poucos dados relacionados aos valores efetivamente arrecadados com os direitos de saída na Província de São Paulo. Os poucos informes encontrados foram compilados e apresentados na Tabela 16.

$\underline{\text { Tabela } 16 \text { - Os Direitos de Saída na São Paulo Imperial: Orcado versus Realizado }}$

\begin{tabular}{cccc}
\hline Ano & $\begin{array}{c}\text { Dízimos - Direitos de Saída } \\
\text { Receita Orçada } \\
\text { (valores nominais) }\end{array}$ & $\begin{array}{c}\text { Dízimos - Direitos de Saída } \\
\text { Receita Realizada } \\
\text { (valores nominais) }\end{array}$ & $\begin{array}{c}\text { Dízimos - Direitos de Saída } \\
\text { Receita Realizada } \\
\text { (em libras esterlinas) }\end{array}$ \\
\hline 1862 & $450: 000 \$ 000$ & $536: 822 \$ 689$ & 58.830 \\
1863 & $450: 000 \$ 000$ & $381: 888 \$ 447$ & 43.357 \\
1864 & $540: 000 \$ 000$ & $595: 437 \$ 500$ & 66.411 \\
1866 & $650: 000 \$ 000$ & $631: 939 \$ 859$ & 63.454 \\
1868 & $700: 000 \$ 000$ & $1.136: 010 \$ 089$ & 78.966 \\
1870 & $1.720: 000 \$ 000$ & $811: 000 \$ 000$ & 74.878 \\
1877 & $1.465: 368 \$ 000$ & $1.791: 542: 338$ & 184.069 \\
1879 & - & $2.485: 820 \$ 315$ & 221.968 \\
\hline \multicolumn{4}{c}{}
\end{tabular}


Observando os dados apresentados, percebe-se que os impressionantes percentuais orçados em 1870 de fato não se concretizaram. Neste ano, a arrecadação com os dízimos/direitos de saída alcançou a metade do que se esperava recolher. No entanto, ao analisarmos o período anterior, 1868, constatamos que os cofres provinciais recolheram um montante $62 \%$ superior ao esperado. E, mais relevante que isso, é a percepção de que, mesmo considerando-se somente os valores realizados, a evolução da arrecadação com os direitos de saída foi significativa, passando de 58.830 libras esterlinas, em 1862, para 221.968 libras esterlinas, em 1879; um crescimento calculado em aproximadamente $277 \%$.

Por meio das análises, apontamentos e considerações efetuadas no decorrer deste tópico, procuramos evidenciar e quantificar a crescente trajetória que os dízimos/direitos de saída adquiriram nas finanças paulistas. Neste sentido, tal movimento tributário em muito foi beneficiado pela expansão cafeeira.

As finanças provinciais passaram por uma progressiva melhoria entre 1870 e 1880, com um aumento de receita proveniente, sobretudo, do café. Foram o café e os tributos a ele vinculados as notas dominantes na legislação, nos relatórios, na vida econômica e fazendária paulista das duas últimas décadas do Império. De sua boa ou má situação, dependeram a prosperidade ou as dificuldades da Administração Provincial. (TESSITORE, 1995. p. 78)

Destarte, a realidade vivenciada por São Paulo no decorrer do Segundo Reinado em muito contribuiu para a sua ascensão econômica, fiscal e, consequentemente, política no rearranjo institucional vivenciado pelas Províncias no período que nos ocupa.

Com a Proclamação da República uma importante medida fiscal foi adotada em prol dos nascentes Estados. Os direitos de saída, rebatizados direitos de exportação dos gêneros e mercadorias de produção do Estado, deixaram de ser compartilhados entre a União e os Estados. Deste modo, o direito de arrecadar esta preciosa fonte de recursos fiscais passou a ser integralmente dos governos locais.

Este imposto consolidou-se como o principal mecanismo de recolhimento fiscal dos Estados. Paralelamente, de acordo com a análise de Love, em muito contribuiu para o aumento das disparidades entre as distintas regiões brasileiras. Estavam dadas as diretrizes a serem seguidas na recém constituída República: 
republicano de 1870: "Centralización, desmembramento, descentralización, unidad". La carta garantizaba una mayor difusión de la autoridad que la de Argentina (1853, revisada en 1860) y la de México (1857 y 1917), las otras dos grandes repúblicas federales de Latino-américa. Estos dos países imponían mayores restricciones a los estados (o provincias) que Brasil, sobre todo al no permitir que sus unidades impusieran impuestos de exportación a los bienes que se movían entre los estados. En Brasil, los impuestos a los produtos enviados fuera del estado (incluyendo las exportaciones) eran la principal fuente de ingressos para los miembros de la federación. [...], la Contitución brasileña de 1891 permitía un alto grado de descentralización. Sin embargo, no llegó a elaborar disposiciones adecuadas para los estados más pobres. Así, como la principal fuente de ingresos para los estados durante la Vieja República era el impuesto de exportación, también el principal surtidor de ingressos para el gobierno federal fueron los impuestos de importación. En la Asamblea constituyente, los diputados de los estados deprimidos del noreste argumentaron a favor de una cuota de ingresos de importación, afirmando que ni las recaudaciones de exportación ni los impuestos sobre la propriedade proporcionarían suficientes fondos para el manejo de sus gobiernos. [...] Así el federalismo incorporado em la Constitución de 1891 era decididamente una associación de miembros desiguales. Ciertos poderes fiscales reservados a los estados, em especial el derecho de gravar las exportaciones y más tarde el de gravar el consumo, volvieron poderosos a los estados ricos, y a los pobres, débeis y dependientes del gobierno federal. (LOVE, 1993, pp. 186-187)

No tocante às questões fiscais, não observamos alterações quanto às principais fontes de receita tributária. O imposto de importação, mais importante fonte de recurso financeiro na época, continuou concentrado no cofre da União. Os governos estaduais passaram a obter total direito sobre as rendas oriundas da tributação sobre a circulação de mercadorias exportadas entre as Províncias e para fora do país. Contudo, averiguamos que ainda era a tributação sobre a circulação e consumo de gêneros e mercadorias a mais valiosa geradora de recursos financeiros para o Erário.

Sendo assim, em 1889, passados quase 400 anos de história, os governantes davam continuidade ao modelo fiscal adotado desde o início da colonização. Observamos que no decorrer dos séculos a estrutura tributária brasileira continuou com as mesmas diretrizes estabelecidas inicialmente. E, somamos a esta constatação, as múltiplas transformações sofridas pelo dízimo.

Nos séculos XVI e XVII a principal ferramenta de recolhimento fiscal era caracterizada pelos dízimos, através da tributação sobre a produção de gêneros primários, principalmente aqueles destinados aos mercados europeus. Desta maneira, os dízimos incidentes sobre as mercadorias exportadas constituíram a "joia da Coroa" nos dois primeiros séculos de nossa história fiscal.

No período subsequente, com a descoberta de ouro e pedras preciosas, o Brasil passou a testemunhar a tributação interna em seu território. Excluindo-se deste debate os impostos 
sobre a produção mineratória, as principais ferramentas tributárias do período foram representadas pela incidência fiscal que recaía sobre a circulação de pessoas, animais e mercadorias, sob a nomenclatura passagens e entradas, respectivamente. Somado a estes impostos, os dízimos ainda figuravam como um precioso fornecedor de receitas fiscais. No entanto, no século XVIII, eles passaram a recair também sobre a produção de gêneros e mercadorias destinada ao mercado consumidor interno.

No início do século XIX, D. João VI, preocupado com a situação fiscal brasileira, procurou dirimir os lucros, assim como os abusos cometidos pelos Contratadores. Por meio do Decreto de 16 de abril de 1821 determinou que os dízimos deveriam deixar de ser recolhidos nas localidades produtoras e passar a ser coletados em postos específicos, entradas das vilas, Alfândegas, Portos Secos e Registros. Desta maneira, possivelmente influenciado pela estrutura das Barreiras e Registros, D. João VI deu uma nova característica aos antigos dízimos. De imposto incidente sobre a produção, os dízimos passaram a recair sobre a circulação de mercadorias.

Por meio da pesquisa empírica realizada nas fontes documentais da Província de São Paulo, verificamos que no ano de 1840 os antigos dízimos passaram a ser classificados como direitos de saída. Após a Proclamação da República esta fonte tributária passou a ser especificada como direitos de exportação dos gêneros e mercadorias de produção do Estado.

Isto posto, procuramos evidenciar que não somente o modelo tributário brasileiro permaneceu o mesmo após quatro séculos de história econômica e fiscal, qual seja, a tributação sobre o consumo. Adicionamos a este fato uma importante comprovação: os dízimos figuraram em todo período analisado com uma das mais importantes ferramentas de recolhimento fiscal em solos brasileiros. Sendo assim, século após século, e a cada momento com uma nova denominação, os dízimos/direitos de saídal direitos de exportação dos gêneros e mercadorias de produção do Estado sempre estiveram presentes, "dizimando" a produção, a circulação e o consumo. 


\section{Capítulo 4}

\section{Raízes da Tributação Sobre o Consumo}

A base de incidência Bens e Serviços é constituída por três tributos federais, um estadual e um municipal. Os tributos federais são compostos pelo Imposto sobre Produtos Industrializados - IPI -, pela Contribuição para o Programa de Integração Social e o Programa de Formação do Patrimônio do Servidor Público - PIS/PASEP - e a Contribuição para o Financiamento da Seguridade Social - COFINS. O Imposto sobre Operações Relativas à Circulação de Mercadorias e sobre Prestação de Serviços de Transporte Interestadual, Intermunicipal e de Comunicação - ICMS - compõe a competência tributária estadual; e o Imposto sobre Serviços de Qualquer Natureza - ISS - constitui uma importante fonte de recursos para os cofres municipais.

No primeiro capítulo procuramos ilustrar a importância arrecadatória que tais fontes tributárias exercem perante as finanças públicas. No segundo e terceiro capítulos apresentamos o contexto histórico, econômico e fiscal que conduziu ao modelo tributário atual, qual seja, a intensa concentração de recolhimento fiscal incidente sobre o consumo. Neste capítulo, temos como objetivo traçar as raízes dos cinco tributos que compõem a base de incidência Bens e Serviços. Para tanto, serão analisadas as fontes legais quando da criação de cada tributo, bem como suas bases de incidência e, quando o caso, qual tributo está sendo substituído.

De acordo com os recortes efetuados no decorrer do trabalho, procuramos apresentar as características fiscais das localidades mais expressivas economicamente de cada período de nossa história. Deste modo, no Período Colonial concentramos nossa atenção no Nordeste açucareiro e, posteriormente, na região da mineração. Verificamos que as práticas tributárias destas regiões exerceram influências e deixaram suas heranças para os futuros polos econômicos e políticos do país.

Com o advento da mineração, o Rio de Janeiro, e sua Alfândega, passou a ganhar representatividade no cenário nacional. Representatividade esta que foi fortalecida com a vinda da Corte no início do século XIX. Sendo assim, o terceiro capítulo procurou entender estes movimentos e analisar de que maneira a fiscalidade se estruturou diante desta nova conjuntura. Tal estrutura fiscal, reiteramos, possui bases nos modelos 
tributários adotados anteriormente. O Período Regencial e o Segundo Reinado testemunharam as transformações promovidas pelo avanço do complexo cafeeiro. Nesta nova realidade, São Paulo se consolidou como a Província mais próspera da Nação. Este contexto nos levou a analisar a configuração fiscal paulista no Oitocentos, bem como verificar a importância que os antigos dízimos, posteriormente denominados direitos de saída, adquiriram no decorrer das décadas.

Deste modo, fica o questionamento: teriam os dízimos deixado suas raízes na atual tributação brasileira, ou o ano de 1934, com o advento do $I V C$, representou uma ruptura com o modelo até então praticado? E o que poderíamos afirmar sobre os demais impostos e contribuições que constituem atualmente a base tributária incidente sobre o consumo? Estaria nossa estrutura fiscal ainda convivendo com impostos coloniais herdados período após período? Para respondermos tais inquietação analisaremos a legislação fiscal do Brasil no período do Império e da República, bem como os documentos do Estado de São Paulo. A justificativa para esta análise, como já o afirmamos, se baseia na expressividade econômica e fiscal exercida pelo território paulista até os dias atuais.

Após esta breve consideração, esclarecemos que a estrutura deste capítulo se dará da seguinte maneira: Iniciaremos as pesquisas com os tributos que compõem a receita federal. Posteriormente, estudaremos o ICMS para tão somente analisarmos o ISS.

\section{Tributos Federais: IPI, PIS/PASEP e COFINS}

\section{Imposto sobre Produtos Industrializados - IPI}

O Imposto sobre Produtos Industrializados foi instituído no Brasil no ano de 1964, por meio da Lei ${ }^{\circ}$ 4.502, de 30 de novembro de 1964.

Dentre as características do imposto está a seletividade, a não cumulatividade e a não incidência do imposto sobre produtos destinados ao exterior. Desta maneira, ao estabelecer que o imposto seja seletivo, tem-se como objetivo tributar as mercadorias de acordo com sua essencialidade. Produtos dito essenciais possuem alíquotas inferiores dos 
produtos considerados supérfluos ${ }^{37}$. Como intuito, esta medida procura exercer a função extrafiscal por meio de critérios que busquem adotar a "justiça tributária" ao atribuir maiores alíquotas aos produtos supérfluos, pois seu mercado consumidor, a priori, estaria entre os cidadãos de maior poder aquisitivo. Paralelamente, este imposto também tem como objetivo inibir o consumo de produtos considerados nocivos à saúde, como bebidas e cigarros, por exemplo. Neste caso, as alíquotas atribuídas a tais mercadorias são superiores às demais.

Por intermédio da não cumulatividade busca-se coibir a incidência do imposto sobre imposto, fato este que implica em altos custos tributários no decorrer da cadeia produtiva e promove intensas distorções no preço final da mercadoria.

Ao determinar a não incidência do IPI sobre as mercadorias destinadas ao exterior, temse como objetivo proteger a indústria nacional. Mediante esta medida procura-se estimular a competitividade dos produtos brasileiros no mercado internacional ${ }^{38}$. A lógica econômica e tributária intrínseca a esta prática advoga que um país não deve "exportar impostos" a outras nações.

Outro ponto importante a ser evidenciado refere-se ao caráter indireto do imposto, mesmo sendo ele um tributo que incide diretamente sobre a produção. Nas palavras de Regina Helena Costa:

O IPI é considerado um imposto indireto, assim entendido aquele cujo ônus financeiro não é suportado pelo contribuinte de jure, mas sim pelo contribuinte de facto, ou o consumidor final. (COSTA, 2016, p. 373)

Contudo, ledo engano supor que o IPI nasceu no ano de 1964. A Lei nº 4.502/64 procurou estabelecer novas diretrizes sobre o fato gerador e a base de incidência do então Imposto de Consumo, ao determinar o recaimento tributário sobre os produtos industrializados.

Lei ${ }^{\circ} 4.502$, de 30 de novembro de 1964 - Dispõe sobre o Imposto de Consumo e reorganiza a Diretoria de Rendas Internas.

Art. 2 - Constitui fato gerador do imposto:

I - Quanto aos produtos de procedência estrangeira, o respectivo desembaraço aduaneiro;

\footnotetext{
${ }^{37}$ As alíquotas são estabelecidas de acordo com a essencialidade do produto e especificadas na Tabela de Incidência do Imposto sobre Produto Industrializado - TIPI. O órgão responsável pela elaboração da TIPI é a Receita Federal do Brasil;

${ }^{38}$ No decorrer das próximas páginas veremos que, na realidade, o precursor do IPI foi instituído com o intuito de substituir a receita fiscal federal proveniente do Imposto de Exportação.
} 
II - Quanto aos de produção nacional, a saída do respectivo estabelecimento produtor.

$\S 1^{\circ}$ Quando a industrialização se der no próprio local de consumo ou de utilização do produto, fora do estabelecimento produtor, o fato gerador considerar-se-á ocorrido no momento em que ficar concluída a operação industrial;

$\S 2^{\circ} \mathrm{O}$ imposto é devido sejam quais forem as finalidades a que se destine o produto ou a título jurídico que se faça a importação ou de que decorra a saída do estabelecimento coprodutor;

Art. 3 - Considera-se estabelecimento produtor todo aquele que industrializar produtos sujeitos ao imposto;

Parágrafo único - Para os efeitos deste artigo considera-se industrialização qualquer operação de que resulte alteração da natureza, funcionamento, utilização, acabamento ou apresentação do produto. (LEI n ${ }^{\circ} 4.502$, de 30 de novembro de 1964)

Deste modo, ao dispor sobre o Imposto de Consumo, a Lei $n^{\circ} 4.502 / 64$ está tratando de um imposto que passou a figurar entre as rendas ordinárias federais em fins do século XIX. A Lei $\mathrm{n}^{\mathrm{o}} 25$, de 30 de dezembro de 1891, estabelece ${ }^{39}$ :

Lei $\mathrm{n}^{\circ} 25$, de 30 de dezembro de 1891 - Orça a receita geral da República dos Estados Unidos do Brasil para o exercício de 1892 e dá outras providências.

\section{Receita Geral}

Art. 1 - A receita geral da República dos Estados Unidos do Brasil é orçada na quantia de 207.992:120\$ e será realizada com o produto do que for arrecadado dentro do exercício da presente lei, sob os títulos abaixo assinados:

\section{Receita Ordinária}

Importação - Expediente dos gêneros livres de direitos de consumo; Expediente das capatazias; Armazenagem; Despacho Marítimo; Imposto de faróis; Imposto de doca; Adicionais: $50 \%$ adicionais sobre os direitos de importação para consumo, menos bacalhau e outros peixes secos, carne de charque, feijão, milho, arroz e vinagre comum ou de cozinha, sendo $60 \%$ a taxa adicional sobre vinhos, cerveja, bebidas alcoólicas, algodão e artefatos de algodão, lã e artefatos de lã, linho e artefatos de linho, seda e artefatos de seda; $10 \%$ adicionais sobre expedientes dos gêneros livres de direitos de consumo, das capatazias, armazenagem, imposto de faróis e de doca.

Exportação - Direitos de 2,5\% da pólvora fabricada por conta do Governo e dos metais preciosos em pó, pinha, barra ou em obra. Direitos de 1,5\% do ouro em barra, fundido na Casa da Moeda.

\footnotetext{
${ }^{39}$ Optamos por reproduzir a Lei integralmente a fim de elencarmos todas as fontes de renda ordinária presentes no período e não somente o Imposto de Consumo. Temos ciência que este não é o objeto de estudo deste tópico, no entanto, conhecer a conjuntura fiscal em seu contexto amplo nos auxilia no entendimento da construção histórica da fiscalidade brasileira.
} 
Interior - Juros das ações das estradas de ferro da Bahia e Pernambuco; Renda da Estrada de Ferro Central do Brasil; Renda das Estradas de ferro custeadas pelo Estado; Renda do Correio Geral; Renda dos Telégrafos Elétricos; Renda da Casa da Moeda; Renda da Imprensa Nacional e Diário Oficial; Renda da Fábrica da Pólvora; Renda da Fábrica de Ferro de Ipanema; Renda dos Arsenais; Renda da Casa de Correção; Renda do Ginásio Nacional; Renda do Instituto dos Surdos Mudos; Renda do Instituto Nacional de Música; Renda das matrículas dos estabelecimentos de instrução superior; Renda dos próprios nacionais; Foros de terrenos e de marinhas, exceto os do Distrito Federal, e produto da renda de posses ou domínios úteis dos terrenos de marinhas, nos termos da legislação em vigor; Laudêmios, não compreendidos os das vendas de terrenos de marinhas no Distrito Federal; Prêmios de depósitos públicos; Selo do papel, aumentadas as taxas com $10 \%$ e cobrada a taxa de $\$ 200$ por $100 \$$ sobre as ações ao portador dos bancos e sociedades anônimas, bem como sobre debêntures ou obrigações ao portador, $1,5 \%$ sobre os dividendos dos bancos, companhias e sociedades anônimas; Imposto de transporte; Imposto sobre o subsídio e vencimentos, elevado a $10 \%$ a imposto sobre o subsídio de deputados e senadores; Cobrança da dívida ativa; Imposto sobre transmissão de propriedade na Capital Federal, aumentadas de $10 \%$ as respectivas taxas.

Consumo - 50 réis por 250 gramas ou fração de 250 gramas de fumo em bruto que for consumido; 20 réis por 50 gramas ou fração de 50 gramas de fumo picado, desfiado ou migado, idem; 20 réis por 20 gramas ou fração de 20 gramas de fumo charutos, idem; 10 réis por 20 gramas ou fração de 20 gramas de cigarros, idem; 10 réis por 30 gramas ou fração de 30 gramas de rapé, tabaco ou caco. Estas taxas serão cobradas em estampilhas. (LEI $\mathrm{n}^{\circ} 25$, de 30 de dezembro de 1891)

Notamos que inicialmente o Imposto de Consumo recaiu somente sobre o fumo. Além disso, ao analisarmos a Constituição Federal do ano de 1891, promulgada em 24 de fevereiro do dito ano, não encontramos menção alguma acerca do Imposto de Consumo. $\mathrm{Na}$ Carta Magna figuram as seguintes rendas da União:

Art. 7 - É da competência exclusiva da União decretar:

$1^{\circ}$ ) Imposto sobre a importação de procedência estrangeira;

$2^{\circ}$ ) Direitos de entrada, saída e estadia de navios, sendo livre o comércio de cabotagem às mercadorias nacionais, bem como às estrangeiras que já tenham pago imposto de importação;

$3^{\circ}$ ) Taxas de selo, salvo a restrição do art. $9, \S 1^{\circ}, n^{\circ} \mathrm{I}$;

$4^{\circ}$ ) Taxa dos correios e telégrafos federais. (CONSTITUIÇÃO FEDERAL de 1891)

Procurando efetuar um minucioso levantamento acerca do Imposto de Consumo, Machado divulgou no ano de 1922 um rico trabalho acerca da conjuntura econômica e política do período. Paralelamente, também efetuou importantes contribuições sobre as disposições legais posteriores ao ano de 1891. No tocante à importância que este mecanismo arrecadatório passou a constituir para as finanças públicas, o autor esclarece: 
Em 1898, o preclaro Ministro Murtinho dizia desses impostos (...) como a melhor prova do valor deles no equilíbrio orçamentário: "É sabido que a decretação desses impostos (de consumo) foi inspirada ao poder legislativo pela imperiosa necessidade de compensar a insuficiência das fontes de renda da União e a consequente depressão de sua receita originadas pela partilha constitucional que transferiu para os Estados entre outros, o imposto de exportação. Era indispensável dotar a União com o numerário preciso para equilibrar o seu orçamento e principalmente para habilitá-la a satisfazer os encargos das dívidas externa e interna sob sua exclusiva responsabilidade e o único meio de conseguir esse escopo não podia ser senão o de pedir ao patriotismo dos contribuintes mais esse sacrifício em prol da comunhão nacional e dos bons créditos da República". (MACHADO, 1922, p. 65)

Diante do exposto, é possível concluir que o Imposto de Consumo surge neste período com o propósito de sanar as finanças do governo federal carentes dos recolhimentos provenientes do Imposto de Exportação. Os recursos financeiros oriundos do Imposto de Exportação continuaram a existir, não foram extintos. Contudo, passaram a constituir integralmente a competência tributária dos $\operatorname{Estados}^{40}$. Sendo assim, coube à população brasileira, em nome de seu patriotismo, socorrer os cofres da União por meio de mais um ônus fiscal.

Como vimos, inicialmente o Imposto de Consumo recaiu somente sobre o fumo, todavia, no decorrer dos anos ocorreu a ampliação da cesta de produtos tributados. O propósito novamente fora o mesmo, suprir o Erário:

A princípio como tentativa exploradora foi apenas lançado o novo tributo sobre o fumo de produção nacional e de procedência estrangeira. Mais tarde, como se reconhecesse que isso não bastava para remediar a situação da receita federal estendeu-se o gravame para as bebidas, fósforos, ao sal e por fim como o resultado da correspondente arrecadação ficasse ainda aquém da expectativa do legislador foi este compelido a fazer incidir a mesma contribuição sobre as velas, o calçado, as conservas, as especialidades farmacêuticas, as perfumarias, o vinagre e as "cartas de jogar”. (MACHADO, 1922, pp. 65-66)

Desta maneira, por meio de inúmeros dispositivos legais os produtos a serem tributados pelo Imposto de Consumo foram ampliados, não se restringindo aos mencionados acima:

Depois da tributação do fumo, feita como ficou exposto, pela Lei $n^{\circ} 25$, de 30 de abril de 1891, verificou-se a dos seguintes produtos:

\footnotetext{
${ }^{40}$ No capítulo anterior apresentamos a realidade fiscal paulista no decorrer do Segundo Reinado. Por meio deste estudo foi possível tomar ciência da relevância dos direitos de saída para a Província de São Paulo. Todavia, no Período Imperial os recursos provenientes desta ferramenta tributária eram compartilhados entre a renda provincial e a renda geral. Com a Proclamação da República os direitos de saída passaram a constituir a competência tributária exclusiva dos Estados, mas agora com outra nomenclatura. No decorrer deste capítulo retornaremos à temática.
} 
Bebidas - Lei n 359 , de 30 de dezembro de 1895;

Fósforos e sal - Lei $\mathrm{n}^{\circ} 489$, de 15 de dezembro de 1897;

Calçados, velas, perfumaria, especialidades farmacêuticas, conservas, cartas de jogar e vinagre - Lei $\mathrm{n}^{\circ}$ 559, de 31 de dezembro de 1898;

Chapéus, bengalas e tecidos - Lei ${ }^{\circ}$ 641, de 14 de novembro de 1899;

Vinhos estrangeiros - Lei $\mathrm{n}^{\circ} 1.313$, de 30 de dezembro de 1904;

Café torrado, artificial - Lei n ${ }^{\circ} 1.616$, de 30 de dezembro de 1906;

Manteiga e banha, nacionais e artificiais - Leis ns. ${ }^{\circ} 1.616$, de 30 de dezembro de 1906 e 2.321, de 30 de dezembro de 1910;

Espartilhos, papel para forrar casas, discos para gramofones, louças e vidros - Lei no 2.919, de 31 de dezembro de 1914;

Ferragens - Lei n ${ }^{\circ}$ 3.070-A, de 31 de dezembro de 1915;

Café torrado ou moído e manteiga - Lei $\mathrm{n}^{\circ} 3.213$, de 30 de dezembro de 1916;

Pilhas elétricas secas, nacionais - Lei $\mathrm{n}^{\circ} 3.644$, de 31 de dezembro de 1918; Açúcar refinado, obras de joalherias, obras de adorno, ornamentos e outros fins, móveis, artefatos de tecidos, armas de fogo e suas munições e lâmpadas elétricas - Lei $\mathrm{n}^{\circ} 3.979$, de 31 de dezembro de 1919. (MACHADO, 1922, pp. 66-67)

Destarte, nãos podemos deixar de considerar neste estudo o início da Primeira Guerra Mundial e suas consequências fiscais deletérias. Para um país que dependia sobremaneira dos impostos aduaneiros, como no caso brasileiro, o declínio das transações comerciais internacionais em muito impactou as finanças públicas. Para tanto, o governo federal buscou, novamente por meio da incidência tributária do mercado interno, suprir a escassez de recolhimento proveniente dos Impostos de Importação. Este contexto bélico nos auxilia no entendimento acerca da ampliação do fato gerador do Imposto de Consumo:

(...) a partir da eclosão da Guerra em 1914, as alterações nas receitas do governo federal passaram a se relacionar não mais apenas às rendas alfandegárias, mas também a um significativo esforço das diferentes gestões do governo federal em aprimorar a arrecadação tributária relativa às atividades destinadas ao mercado interno que vinham, a partir de então, assumindo uma participação cada vez mais significativa no produto nacional. (GRANDI; SAES, s.d.)

O objetivo primordial foi alcançado, o Imposto de Consumo passou a figurar entre as principais fontes de renda do governo federal. Inclusive, alcançou o posto de segunda principal fornecedora de recursos fiscais para a União, ficando atrás somente do Imposto de Importação:

Para que bem se conheça da importância atual destes impostos, basta repetir com o Ministro Homero Baptista ${ }^{41}$, que eles constituem a mais poderosa fonte de renda, depois do imposto de importação, e seria difícil avaliar até que ponto irá a sua capacidade tributária, por isso que o seu crescimento acompanha a evolução das nossas indústrias. (MACHADO, 1922, p. 66)

\footnotetext{
${ }^{41}$ Ministro da Fazenda do governo de Epitácio Pessoa, 1919-1922.
} 
Com o intuito de mensurarmos a importância que o Imposto de Consumo adquiriu no decorrer das décadas, e avaliarmos sua expressividade arrecadatória, apresentamos abaixo o Quadro 38:

Quadro 38 - Arrecadação do Imposto de Consumo, (1892-1920)

\begin{tabular}{|c|c|c|}
\hline Ano & Rendimento & $\begin{array}{l}\text { Cálculo per } \\
\text { capita }\end{array}$ \\
\hline 1892 & $264: 836 \$ 850$ & $\$ 017$ \\
\hline 1893 & $864: 174 \$ 500$ & $\$ 056$ \\
\hline 1894 & $812: 973 \$ 188$ & $\$ 052$ \\
\hline 1895 & $841: 119 \$ 566$ & $\$ 053$ \\
\hline 1896 & $1.570: 435 \$ 095$ & $\$ 097$ \\
\hline 1897 & $1.978: 439 \$ 091$ & $\$ 129$ \\
\hline 1898 & 13.076:092\$880 & $\$ 784$ \\
\hline 1899 & $25.475: 388 \$ 594$ & $1 \$ 499$ \\
\hline 1900 & $36.693: 479 \$ 895$ & $2 \$ 118$ \\
\hline 1901 & $31.566: 439 \$ 326$ & $1 \$ 165$ \\
\hline 1902 & $33.959: 712 \$ 532$ & $1 \$ 839$ \\
\hline 1903 & $35.374: 129 \$ 101$ & $1 \$ 855$ \\
\hline 1904 & $35.367: 867 \$ 557$ & $1 \$ 795$ \\
\hline 1905 & $35.232: 666 \$ 447$ & $1 \$ 731$ \\
\hline 1906 & $43.496: 296 \$ 271$ & $1 \$ 795$ \\
\hline 1907 & $47.977: 269 \$ 065$ & $2 \$ 209$ \\
\hline 1908 & $44.591: 226 \$ 116$ & $2 \$ 001$ \\
\hline 1909 & $45.743: 964 \$ 541$ & $2 \$ 003$ \\
\hline 1910 & $54.628: 428 \$ 094$ & $2 \$ 333$ \\
\hline 1911 & $59.768: 902 \$ 243$ & $2 \$ 489$ \\
\hline 1912 & $62.539: 417 \$ 591$ & $2 \$ 540$ \\
\hline 1913 & $65.242: 219 \$ 533$ & $2 \$ 594$ \\
\hline 1914 & $52.327: 769 \$ 075$ & $2 \$ 023$ \\
\hline 1915 & $67.775: 581 \$ 517$ & $2 \$ 553$ \\
\hline 1916 & $83.827: 927 \$ 725$ & $3 \$ 118$ \\
\hline 1917 & $117.719: 906 \$ 285$ & $4 \$ 282$ \\
\hline 1918 & 119.719:073\$372 & $4 \$ 263$ \\
\hline 1919 & $131.880: 675 \$ 568$ & $4 \$ 585$ \\
\hline 1920 & $175.635: 589 \$ 920,5$ & $5 \$ 763$ \\
\hline
\end{tabular}

Os números são expressivos. Notamos como, ano após ano, o recolhimento fiscal elevouse consideravelmente. Em 1892, primeiro ano de vigência do tributo, o montante arrecadado totalizou 264:836\$850. No ano de 1920, último ano da série, a receita financeira com o Imposto de Consumo somou 175.635:589\$920. Em suma, no período de quase três décadas ocorreu uma variação, em termos nominais, superior a $66.000 \%$. O desempenho da arrecadação per capita, ao confrontarmos o ano inicial e o final, também foi elevado, totalizou $33.000 \%$. Mesmo representando a metade da variação nominal 
total, este número não pode ser ignorado, uma vez que reflete diretamente o peso que a carga tributária exerce sobre o contribuinte.

Procurando entender o impacto que este comportamento gerou nas finanças públicas, analisamos a participação do Imposto de Consumo no cômputo total da receita da União. Verificamos a elevação de sua representatividade arrecadatória, principalmente a partir do ano de 1914. Além disso, por meio do Gráfico 15, é possível constatar que a queda da arrecadação com o Imposto de Importação foi parcialmente suprida pela elevação de recolhimento do Imposto de Consumo.

\section{Gráfico 15 - Participacão percentual dos Impostos de Importacão, Consumo e Renda no Total da Receita da União, (1900-1930)}

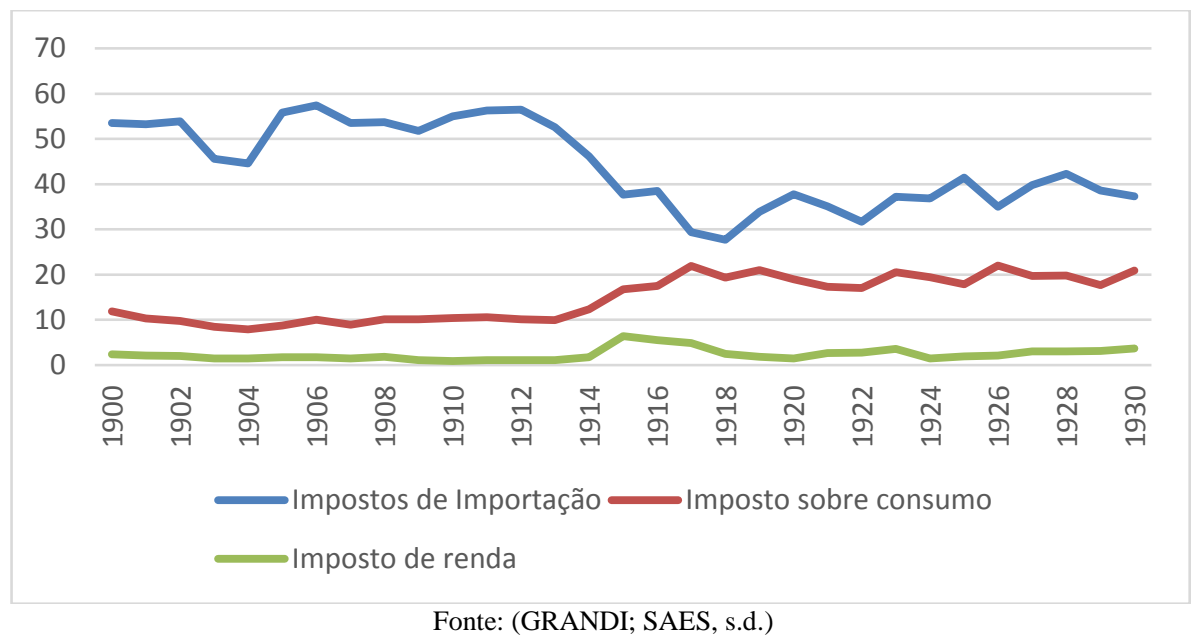

O Imposto de Importação representava no ano de 1900 aproximadamente $55 \%$ do recolhimento fiscal da União. O Imposto de Consumo, neste mesmo ano, correspondia a pouco mais de $10 \%$ da receita tributária. No período da Guerra esta diferença caiu consideravelmente. Enquanto o Imposto de Consumo passou a contribuir com aproximados $20 \%$ para o recolhimento fiscal total, o Imposto de Importação contribuiu, em média, com 30\%. É bem de se ver que no período pós-Guerra, 1818, as curvas voltaram a se distanciar. No entanto, a representatividade do Imposto de Consumo não voltou aos patamares pré-Guerra. Ao contrário, manteve no decorrer da década de 1920 os mesmos percentuais alcançados em 1917. O Imposto de Importação, ao contrário, não atingiu no decorrer da década de 1920 os níveis experimentados antes dos confrontos bélicos. 
Não à toa, é possível observarmos que o valor bruto arrecadado com o imposto sobre o consumo interno sofreu um aumento, em termos nominais, de $158,5 \%$ entre 1915 e 1920 e, entre 1921 e 1928, a arrecadação desse imposto ascendeu de aproximadamente 154 mil contos de réis para um pouco mais de 440 mil contos, isto é, um aumento nominal da ordem de $185,7 \%$. Os dados sugerem ter havido uma preocupação do governo federal em reconstruir suas bases fiscais por meio do mercado interno durante a presidência de Arthur Bernardes [1922-1926 - C.S.]. (GRANDI; SAES, s.d.)

Desta maneira, é possível concluir que a política fiscal adotada pela União convergiu para a tributação do mercado consumidor interno. No ano de 1891 tal decisão foi influenciada por consequências negativas geradas à renda federal com a transferência do Imposto de Exportação para os Estados. Não obstante, em 1914 um novo impacto danoso nos impostos aduaneiros promoveu o aumento da expressividade arrecadatória fiscal do Imposto de Consumo. Com o intuito de compreendermos quais foram os setores internos mais afetados pelo Imposto de Consumo, apresentamos o Gráfico 16.

\section{Gráfico 16 - Participação Relativa por Produto na Receita do Imposto de Consumo, (1925)}

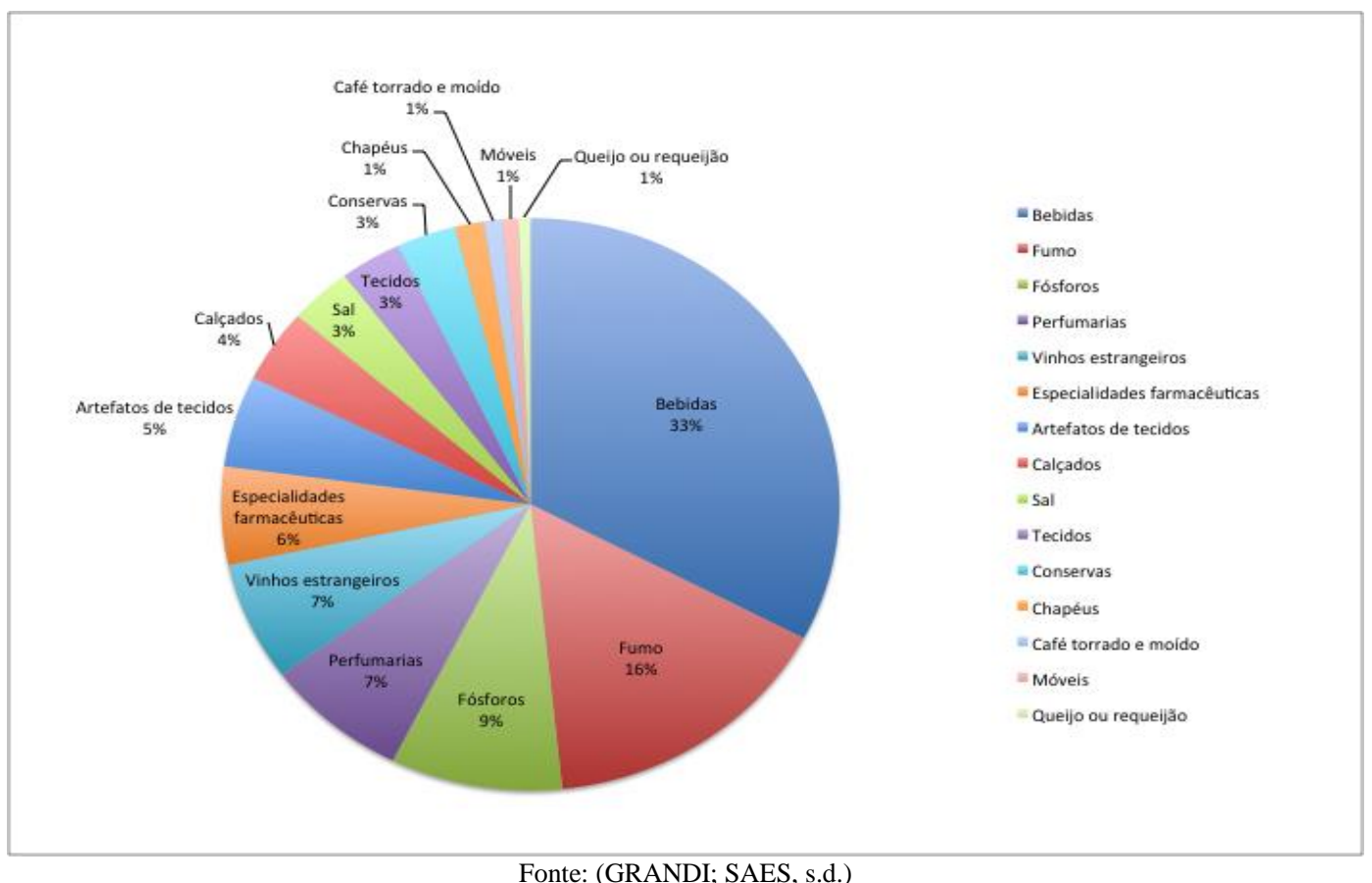

Em 1891, ano no qual o Imposto de Consumo foi instituído, somente o fumo foi tributado. No decorrer dos anos demais produtos passaram a compor o fato gerador deste imposto, conforme ilustramos acima. Desta maneira, no ano de 1925 a mercadoria que mais fornecia receitas fiscais para a União, mediante este tributo, era a bebida. Não obstante, 
o fumo ocupava o segundo lugar da lista. O somatório destes dois itens de consumo contribuiu para $49 \%$ do recolhimento total do Imposto de Consumo. Os $51 \%$ restantes estavam divididos em 16 produtos.

Por meio dos dados apresentados até o momento é possível concluir que década após década, século após século, a característica essencial do modelo físcal brasileiro continuava a ser a tributação indireta e regressiva. Este ponto de vista também era compartilhado pelo Presidente da República:

Para Arthur Bernardes, o cerne do problema era a "má distribuição dos tributos" e o seu caráter excessivamente regressivo: os direitos sobre a importação e o imposto de consumo, por serem indiretos e já estarem no seu limite, pesavam, sobretudo, sobre as classes populares e vinham comprometendo a produção. (GRANDI; SAES, s.d.)

Isto posto, por meio desta breve narrativa procuramos refazer os passos que culminaram no atual IPI. Verificamos os aspectos políticos e financeiros que motivaram a criação do Imposto de Consumo, acompanhamos o seu desempenho arrecadatório no decorrer de quase quatro décadas e analisamos a ampliação de sua base de incidência.

Deste modo, tendemos a concluir que o Imposto de Consumo passou a figurar na fiscalidade brasileira a partir do ano de 1891. De fato, a nomenclatura Imposto de Consumo foi criada neste ano, incidindo inicialmente somente sobre o fumo. Entretanto, é errôneo afirmar que não há no passado fiscal brasileiro mecanismos semelhantes de tributação. Neste momento necessitamos retomar algumas informações que já foram expostas no decorrer desta pesquisa.

No capítulo anterior deste estudo apresentamos inúmeros Quadros correspondentes aos tributos existentes no ano de 1828. Com o intuito de compreendermos os principais fatos geradores de receita fiscal do período, agrupamos os Quadros de acordo com sua matéria tributada. O Quadro 29 - Relação dos Tributos Incidentes sobre os Gêneros, demonstra haver incidências tributárias sobre inúmeras mercadorias produzidas e/ou consumidas no Brasil, a saber: Contribuição da junta do comércio; Contribuição de 40 réis no sal brasileiro; Imposto da aguardente brasileira; Imposto da aguardente de consumo; Imposto de tabaco em pó, dentre outros.

Sendo assim, é possível constatar que o atual Imposto sobre Produtos Industrializados é diretamente originário do Imposto de Consumo, a legislação nos permite traçar esta linha reta. Contudo, é precipitado alegar ser este modelo tributário um fato inédito no Brasil no 
ano de 1891. Os legisladores da recém proclamada República, em realidade, ressuscitaram mecanismos fiscais utilizados no Brasil Colônia. Mecanismos estes que, em sua maioria, não eram praticados em todo o território nacional, mas antes arrecadados em poucas Províncias e cada qual com sua legislação e alíquota própria, conforme ilustrado no Quadro 29.

A necessidade que se fazia presente em 1891, já o dissemos, era a urgência em suprir o impacto negativo gerado aos cofres federais devido à transferência do Imposto de Exportação para as rendas estaduais. Todavia, o instrumental encontrado para a solução da problemática nada mais foi do que a utilização de antigas práticas coloniais tributárias.

Sem embargo, podemos concluir que o atual Imposto sobre Produtos Industrializados possui suas raízes e heranças no sistema fiscal vigente antes da Proclamação da Independência. Seria um equívoco de nossa parte atribuir um único imposto ou contribuição como o ponto de origem do Imposto de Consumo. Observamos inúmeros tributos incidentes sobre diversas mercadorias consumidas e ou/produzidas em diversas localidades do território nacional que influenciaram a criação do Imposto de Consumo. Machado corrobora com este ponto de vista:

Até 1808, cresce enormemente a lista das contribuições, porém, no momento devemos apenas mencionar as que incidiam sobre os produtos brasileiros e que afinal se transfiguraram na evolução dos tempos dando uma ideia de como se fez a marcha para a taxação do consumo, exclusão feita da importação para o consumo, e assim temos: Donativos das caixas e feixos de açúcar, Carta Regia de 04 de fevereiro de 1662; Imposto de tabaco em pó, Carta Regia de 21 de dezembro de 1692, além do dízimo e outros impostos denominados Equivalentes. (MACHADO, 1922, pp. 0506)

Desta maneira, é correto afirmar que o modelo tributário colonial influenciou e deixou suas marcas no atual sistema fiscal brasileiro. O atual Imposto sobre Produtos Industrializados é tão somente uma clara evidência desta constatação. Vejamos a seguir o que se procede com as demais rendas fiscais incidentes sobre a atual base Bens $e$ Serviços.

\section{PIS/PASEP e COFINS}

As contribuições sociais PIS/PASEP $e$ a COFINS representam importantes ferramentas de recolhimento fiscal para a União. Por meio do Quadro 12 foi possível constatar que a 
COFINS representa o quarto principal tributo do território nacional, sendo responsável no ano de 2016 por quase $10 \%$ de toda a receita tributária brasileira. O PIS/PASEP ocupa a oitava posição, contribuindo com aproximadamente $2,61 \%$ do recolhimento fiscal da Nação. Importante mencionarmos que o IPI está logo abaixo do PIS/PASEP, e representa pouco mais de $2 \%$ do recolhimento nacional.

Uma das principais características das contribuições refere-se ao fato de não haver a obrigatoriedade em compartilhar o produto de sua arrecadação com os demais entes federativos. Deste modo, as receitas fiscais oriundas do PIS/PASEP e da COFINS pertencem integralmente ao Erário federal. Em contrapartida, seus recursos devem ser integralmente destinados ao fim a que se propõem. Não há a possibilidade em se efetuar tal arrecadação fiscal com o intuito de destinar os recursos conforme as necessidades orçamentárias se fizerem presentes, como no caso dos impostos. Deste modo,

As contribuições sociais constituem instrumentos de atuação da União na área social, (...) e podem ser instituídas para alcançar finalidades relativas à seguridade social, à educação, à cultura e ao desporto, à ciência e à tecnologia, à comunicação social, ao meio ambiente, à família, à criança, ao adolescente, ao idoso e aos índios". (COSTA, 2016, p. 156)

Quanto às suas fundações, o Programa de Integração Social - PIS - foi criado pela Lei Completar $n^{\circ}$ 07, de 07 de setembro de 1970. O Programa de Formação do Patrimônio do Servidor Público - PASEP - foi criado pela Lei Complementar $n^{\circ} 08$, de 03 de dezembro de 1970. Os objetivos destes programas, quando criados, eram:

Integrar o empregado na vida e no desenvolvimento das empresas, assegurar ao empregado e ao servidor público a formação de patrimônio individual progressivo, estimular a poupança e corrigir distorções na distribuição de renda e possibilitar a paralela utilização dos recursos acumulados em favor do desenvolvimento econômico-social. (FAZENDA, Tesouro Nacional)

A Lei Complementar $\mathrm{n}^{\mathrm{o}}$ 26, de 11 de setembro de 1975, unificou os Programas, constituindo o Fundo PIS/PASEP.

Todavia, com o advento da Constituição Federal de 1988 a destinação dos recursos obtidos pelo Fundo PIS/PASEP foi alterada por meio do art. 239:

Art. 239 - A arrecadação decorrente das contribuições para o Programa de Integração Social, criado pela Lei Complementar $\mathrm{n}^{\circ} 7$, de 7 de setembro de 1970, e para o Programa de Formação do Patrimônio do Servidor Público, criado pela Lei Complementar no 8, de 3 de dezembro de 1970, passa, a partir da promulgação desta Constituição, a financiar, nos termos que a lei 
dispuser, o programa do seguro-desemprego, outras ações da previdência social e o abono de que trata o $\S 3^{\circ}$ deste artigo.

$\S 1^{\circ}$ Dos recursos mencionados no caput, no mínimo $28 \%$ (vinte e oito por cento) serão destinados para o financiamento de programas de desenvolvimento econômico, por meio do Banco Nacional de Desenvolvimento Econômico e Social, com critérios de remuneração que preservem o seu valor.

$\S 3^{\circ}$ Aos empregados que percebam de empregadores que contribuem para o Programa de Integração Social ou para o Programa de Formação do Patrimônio do Servidor Público, até dois salários mínimos de remuneração mensal, é assegurado o pagamento de um salário mínimo anual, computado neste valor o rendimento das contas individuais, no caso daqueles que já participavam dos referidos programas, até a data da promulgação desta Constituição.

$\S 4^{\circ} \mathrm{O}$ financiamento do seguro-desemprego receberá uma contribuição adicional da empresa cujo índice de rotatividade da força de trabalho superar o índice médio da rotatividade do setor, na forma estabelecida por lei. (CONSTITUIÇÃO FEDERAL de 1988)

Atualmente o PIS/PASEP constitui um importante mecanismo de recolhimento tributário cujo objetivo configura-se em financiar programas de desenvolvimento econômico e seguro-desemprego.

A COFINS, por sua vez, foi criada pela Lei Complementar $\mathrm{n}^{\mathrm{o}} 70$, de 30 de dezembro de 1991. Esta contribuição substituiu o FINSOCIAL, criado por meio do Decreto Lei $\mathrm{n}^{\circ}$ 1.940, de 25 de maio de 1982.

Tanto o PIS/PASEP quanto a COFINS possuem como base de cálculo para a incidência do tributo o faturamento das Pessoas Jurídicas, havendo diferenças nas alíquotas aplicadas. Deste modo, estamos tratando de contribuições que efetuam seu recolhimento fiscal mediante a atividade comercial empresarial ${ }^{42}$, ou seja, a venda de mercadorias e/ou prestação de serviços, e sua receita bruta. Por meio desta sistemática arrecadatória, ambas as contribuições são consideradas ferramentas fiscais que impactam o preço final da mercadoria. Consequentemente, novamente temos o consumo sendo indiretamente tributado.

Ademais, as contribuições foram originadas no século XX, possuindo como finalidade tributar a atividade comercial e direcionar os recursos fiscais a causas sociais. Não encontramos na história fiscal brasileira tributos que possam ser diretamente relacionados à origem do PIS/PASEP e do FINSOCIAL/COFINS. Neste sentido, estas contribuições

\footnotetext{
42 Existe na área do direito tributário um intenso debate acerca da legalidade destas contribuições, uma vez que sua incidência recai sobre o faturamento das Pessoas Jurídicas e não sobre seu lucro.
} 
não possuem tributos que possam ser considerados seus precursores diretos. No entanto, precisamos ter cautela ao afirmar que não há na historiografia brasileira práticas semelhantes a essas que não tenham sido utilizadas.

No século XVIII o Marquês de Pombal, procurando meios para financiar a educação pública após promover a expulsão do Jesuítas das terras brasileiras, determinou que entrasse em vigor o Subsídio Literário. Por meio da Lei de 10 de novembro de 1772 ficou estabelecida a alíquota de $3 \$ 600$ réis por pipa de aguardente da terra e 320 réis por cada rês que se corta. Sendo assim, há no ano de 1772 a criação de um mecanismo fiscal cujo ensejo era tributar a produção e o consequente consumo de aguardente e carnes com o intuito de promover a destinação do recurso para um fim social, a educação. Além disso, de acordo com os dados apresentados no Quadro 29, é possível observar que no ano de 1828 este tributo se fazia presente nas 18 Províncias existentes no período. Passados quase duzentos anos da criação do Subsídio Literário entram em cena o PIS e o PASEP.

Diante do exposto, podemos concluir que há precedentes na tributação colonial brasileira que, se não estão diretamente relacionados às atuais contribuições sociais, certamente deixaram suas marcas e influências. Novamente desejamos enaltecer que não estamos afirmando ser o Subsídio Literário o precursor direto dos atuais PIS/PASEP e COFINS. Entretanto, a lógica fiscal que permeava o Subsídio Literário se faz presente, tributar o consumo e destinar os recursos a causas sociais.

\section{$\underline{\text { Imposto Estadual: ICMS }}$}

O Imposto sobre Operações Relativas à Circulação de Mercadorias e sobre Prestação de Serviços de Transporte Interestadual, Intermunicipal e Comunicação - ICMS - se caracteriza como o principal instrumento de recolhimento fiscal do Brasil. De acordo com os dados apresentados no primeiro capítulo desta pesquisa, mais de $20 \%$ de todo o recurso tributário do país é proveniente deste imposto. Ademais, o recolhimento gerado pelo ICMS constitui mais de $80 \%$ da receita fiscal do Estado de São Paulo. O ICMS entrou em vigor com o advento da Constituição Federal de 1988. Em seu artigo nº 155, a Constituição dispõe: 
Art. 155 - Compete aos Estados e ao Distrito Federal instituir impostos sobre:

I - Transmissão causa mortis e doação, de quaisquer bens ou direitos;

II - Operações relativas à circulação de mercadorias e sobre prestações de serviços de transporte interestadual e intermunicipal e de comunicação, ainda que as operações e as prestações se iniciem no exterior;

III - Propriedade de veículos automotores.

$\S 2^{\circ} \mathrm{O}$ imposto previsto no inciso II atenderá ao seguinte:

I - Será não cumulativo, compensando-se o que for devido em cada operação relativa à circulação de mercadorias ou prestação de serviços com o montante cobrado nas anteriores pelo mesmo ou outro Estado ou pelo Distrito Federal;

III - Poderá ser seletivo, em função da essencialidade das mercadorias e dos serviços;

IV - Resolução do Senado Federal, de iniciativa do Presidente da República ou de um terço dos Senadores, aprovada pela maioria absoluta de seus membros, estabelecerá as alíquotas aplicáveis às operações e prestações, interestaduais e de exportação;

V - É facultado ao Senado Federal:

a) estabelecer alíquotas mínimas nas operações internas, mediante resolução de iniciativa de um terço e aprovada pela maioria absoluta de seus membros;

b) fixar alíquotas máximas nas mesmas operações para resolver conflito específico que envolva interesse de Estados, mediante resolução de iniciativa da maioria absoluta e aprovada por dois terços de seus membros; VI - Salvo deliberação em contrário dos Estados e do Distrito Federal, nos termos do disposto no inciso XII, g, as alíquotas internas, nas operações relativas à circulação de mercadorias e nas prestações de serviços, não poderão ser inferiores às previstas para as operações interestaduais;

VII - Nas operações e prestações que destinem bens e serviços a consumidor final, contribuinte ou não do imposto, localizado em outro Estado, adotar-se-á a alíquota interestadual e caberá ao Estado de localização do destinatário o imposto correspondente à diferença entre a alíquota interna do Estado destinatário e a alíquota interestadual;

IX - Incidirá também:

a) sobre a entrada de bem ou mercadoria importados do exterior por pessoa física ou jurídica, ainda que não seja contribuinte habitual do imposto, qualquer que seja a sua finalidade, assim como sobre o serviço prestado no exterior, cabendo o imposto ao Estado onde estiver situado o domicílio ou o estabelecimento do destinatário da mercadoria, bem ou serviço;

b) sobre o valor total da operação, quando mercadorias forem fornecidas com serviços não compreendidos na competência tributária dos Municípios;

X - Não incidirá:

a) sobre operações que destinem mercadorias para o exterior, nem sobre serviços prestados a destinatários no exterior, assegurada a manutenção e o aproveitamento do montante do imposto cobrado nas operações e prestações anteriores. (CONSTITUIÇÃO FEDERAL de 1988)

No tocante à elucidação sobre as incidências e operações que caracterizam fato gerador do ICMS, a Lei Complementar nº 87, de 13 de setembro de 1996, esclarece: 
Art. 2 - O imposto incide sobre:

I - Operações relativas à circulação de mercadorias, inclusive o fornecimento de alimentação e bebidas em bares, restaurantes e estabelecimentos similares;

II - Prestações de serviços de transporte interestadual e intermunicipal, por qualquer via, de pessoas, bens, mercadorias ou valores;

III - Prestações onerosas de serviços de comunicação, por qualquer meio, inclusive a geração, a emissão, a recepção, a transmissão, a retransmissão, a repetição e a ampliação de comunicação de qualquer natureza;

IV - Fornecimento de mercadorias com prestação de serviços não compreendidos na competência tributária dos Municípios;

V - Fornecimento de mercadorias com prestação de serviços sujeitos ao imposto sobre serviços, de competência dos Municípios, quando a lei complementar aplicável expressamente o sujeitar à incidência do imposto estadual.

$\S 1^{\circ} \mathrm{O}$ imposto incide também:

I - Sobre a entrada de mercadoria ou bem importados do exterior, por pessoa física ou jurídica, ainda que não seja contribuinte habitual do imposto, qualquer que seja a sua finalidade;

II - Sobre o serviço prestado no exterior ou cuja prestação se tenha iniciado no exterior;

III - Sobre a entrada, no território do Estado destinatário, de petróleo, inclusive lubrificantes e combustíveis líquidos e gasosos dele derivados, e de energia elétrica, quando não destinados à comercialização ou à industrialização, decorrentes de operações interestaduais, cabendo o imposto ao Estado onde estiver localizado o adquirente.

$\S 2^{\circ}$ A caracterização do fato gerador independe da natureza jurídica da operação que o constitua.

Art. 12 - Considera-se ocorrido o fato gerador do imposto no momento:

I - Da saída de mercadoria de estabelecimento de contribuinte, ainda que para outro estabelecimento do mesmo titular;

II - Do fornecimento de alimentação, bebidas e outras mercadorias por qualquer estabelecimento;

III - Da transmissão a terceiro de mercadoria depositada em armazém geral ou em depósito fechado, no Estado do transmitente;

IV - Da transmissão de propriedade de mercadoria, ou de título que a represente, quando a mercadoria não tiver transitado pelo estabelecimento transmitente;

V - Do início da prestação de serviços de transporte interestadual e intermunicipal, de qualquer natureza;

VI - Do ato final do transporte iniciado no exterior;

VII - Das prestações onerosas de serviços de comunicação, feita por qualquer meio, inclusive a geração, a emissão, a recepção, a transmissão, a retransmissão, a repetição e a ampliação de comunicação de qualquer natureza;

VIII - Do fornecimento de mercadoria com prestação de serviços:

a) não compreendidos na competência tributária dos Municípios;

b) compreendidos na competência tributária dos Municípios e com indicação expressa de incidência do imposto de competência estadual, como definido na lei complementar aplicável;

IX - Do desembaraço aduaneiro de mercadorias ou bens importados do exterior; 
$\mathrm{X}$ - Do recebimento, pelo destinatário, de serviço prestado no exterior; XI - Da aquisição em licitação pública de mercadorias ou bens importados do exterior e apreendidos ou abandonados;

XII - Da entrada no território do Estado de lubrificantes e combustíveis líquidos e gasosos derivados de petróleo e energia elétrica oriundos de outro Estado, quando não destinados à comercialização ou à industrialização;

XIII - Da utilização, por contribuinte, de serviço cuja prestação se tenha iniciado em outro Estado e não esteja vinculada a operação ou prestação subsequente.

$\S 1^{\circ} \mathrm{Na}$ hipótese do inciso VII, quando o serviço for prestado mediante pagamento em ficha, cartão ou assemelhados, considera-se ocorrido o fato gerador do imposto quando do fornecimento desses instrumentos ao usuário.

$\S 2^{\circ}$ Na hipótese do inciso IX, após o desembaraço aduaneiro, a entrega, pelo depositário, de mercadoria ou bem importados do exterior deverá ser autorizada pelo órgão responsável pelo seu desembaraço, que somente se fará mediante a exibição do comprovante de pagamento do imposto incidente no ato do despacho aduaneiro, salvo disposição em contrário.

$\S 3^{\circ} \mathrm{Na}$ hipótese de entrega de mercadoria ou bem importados do exterior antes do desembaraço aduaneiro, considera-se ocorrido o fato gerador neste momento, devendo a autoridade responsável, salvo disposição em contrário, exigir a comprovação do pagamento do imposto. (LEI Complementar $\mathrm{n}^{\circ}$ 87, de 13 de setembro de 1996

Sendo assim, estão dadas as normas legais do ICMS, suas regras de funcionamento, base de incidência e fato gerador. Além disso, cabe-nos destacar que a criação deste tributo obedeceu ao objetivo de ampliar a base de tributação do antigo ICM - Imposto sobre Operações Relativas à Circulação de Mercadorias - ao incorporar as operações sobre prestação de serviços de transporte interestadual, intermunicipal e de comunicação em seu escopo.

No tocante ao ICM, este imposto foi criado na década de 1960, período que passou por intensas reformulações na estrutura tributária brasileira. $\mathrm{O}$ intuito da criação do $I C M$ foi promover a alteração da base de cálculo do antigo IVC - Imposto sobre Vendas $e$ Consignações - visto que este era um tributo cumulativo. A Emenda Constitucional $\mathrm{n}^{\circ}$ 18 , de $1^{\circ}$ de dezembro de 1965 , dispõe sobre o ICM:

Seção IV - Impostos sobre a Produção, e a Circulação

Art. 12. Compete aos Estados o imposto sobre operações relativas à circulação de mercadorias, realizadas por comerciantes, industriais e produtores. 
$\S 1^{\circ}$ A alíquota do imposto é uniforme para todas as mercadorias, não excedendo, nas operações que as destinem a outro Estado, o limite fixado em resolução do Senado Federal, nos termos do disposto em lei complementar.

$\S 2^{\circ} \mathrm{O}$ imposto é não-cumulativo, abatendo-se, em cada operação, nos termos do disposto em lei complementar, o montante cobrado nas anteriores, pelo mesmo ou por outro Estado, e não incidirá sobre a venda a varejo, diretamente ao consumidor, de gêneros de primeira necessidade, definidos como tais por ato do Poder Executivo Estadual. (EMENDA Constitucional $\mathrm{n}^{\mathrm{o}} 18$, de $1^{\circ}$ de dezembro de 1965)

Por sua vez, o IVC - Imposto sobre Vendas e Consignações - foi criado por meio da Constituição Federal de 1934:

Art. 8 - Também compete privativamente aos Estados:

I - Decretar impostos sobre:

a) propriedade territorial, exceto a urbana;

b) transmissão de propriedade causa mortis;

c) transmissão de propriedade imobiliária inter vivos, inclusive a sua incorporação ao capital da sociedade;

d) consumo de combustíveis de motor de explosão;

e) vendas e consignações efetuadas por comerciantes e produtores, inclusive os industriais, ficando isenta a primeira operação do pequeno produtor, como tal definido na lei estadual;

f) exportação das mercadorias de sua produção até o máximo de dez por cento ad valorem, vedados quaisquer adicionais;

g) indústrias e profissões;

h) atos emanados do seu governo e negócios da sua economia ou regulados por lei estadual;

II - Cobrar taxas de serviços estaduais.

$\S 11^{\circ} \mathrm{O}$ imposto de vendas será uniforme, sem distinção de procedência, destino ou espécie dos produtos.

$\S 2 .^{\circ} \mathrm{O}$ imposto de indústrias e profissões será lançado pelo Estado e arrecadado por este e pelo Município em partes iguais.

$\S 3 .^{\circ}$ Em casos excepcionais, o Senado Federal poderá autorizar, por tempo determinado, o aumento do imposto de exportação, além do limite fixado na letra $f$ do número I. (CONSTITUIÇÃO FEDERAL de 1934)

A Constituição de 1934 merece especial atenção, pois, conforme a "alínea e" foi criado o Imposto sobre Vendas e Consignações. Inclusive, o Art. $8, \S 1 .^{\circ}$, determina que "o imposto de vendas será uniforme, sem distinção de procedência, destino ou espécie dos produtos”. Desta maneira, é possível concluir que as vendas internas ocorridas no território estadual passaram a ser tributadas. Sim, internas, pois cabia ao Imposto de Exportação tributar as mercadorias destinadas a outros Estados ou países. 
Além disso, os dispositivos legais nada afirmam quanto a proibição em haver a incidência do IVC sobre os produtos destinados ao exterior. A "alínea f" determina a alíquota máxima de $10 \%$ para as exportações de mercadorias de produção dos Estados. Entendemos que este dispositivo se refere ao Imposto de Exportação. Todavia, não podemos concluir que não ocorreu a tributação do $I V C$ sobre as mercadorias destinadas ao exterior ${ }^{43}$.

Seguindo esta linha de raciocínio, é possível afirmar que o $I V C$, em essência, promoveu a ampliação do fato gerador do então Imposto de Exportação. Em suma, ocorreu, por parte do Estado de São Paulo, a incorporação do Imposto de Exportação pelo IVC, mas agora com uma matéria tributada estendida, passando a incidir também sobre as mercadorias vendidas e consumidas no próprio território paulista.

A hipótese que pretendemos defender é que o atual $I C M S$, originário do $I V C$, possui sua raiz histórica no Imposto de Exportação. Neste sentido, temos tão somente a ampliação do fato gerador do dito imposto, tal qual ocorreu em 1988 quando o ICMS promoveu a ampliação do fato gerador do ICM. A legislação paulista do ano de 1935 nos permite sustentar e defender esta hipótese:

Lei $\mathrm{n}^{\circ} 2.485$, de 16 de dezembro de 1935 - Modifica o sistema tributário do Estado

Artigo 1 - Ficam abolidos, desde 01 de janeiro de 1936, os seguintes impostos e taxas estaduais:

01) - impostos de exportação;

02) - impostos sobre casas de diversões;

03) - imposto predial da Capital;

04) - imposto de comércio;

05) - imposto de indústria;

06) - imposto sobre o capital realizado das sociedades anônimas;

07) - imposto sobre o capital particular empregado em empréstimos;

08) - imposto sobre a renda anual dos prédios de aluguel;

09) - imposto territorial urbano;

10) - imposto sobre consumo de aguardente e bebidas semelhantes;

11) - imposto sobre veículos;

12) - imposto sobre terrenos marginais às estradas de rodagem;

13) - imposto sobre matança de gado;

14) - imposto de emergência sobre o café;

15) - imposto de gasolina;

${ }^{43}$ Os levantamentos e conclusões apontados a partir deste momento foram obtidos mediante o minucioso estudo da documentação paulista, sua legislação e orçamento. Deste modo, a análise acerca das raízes do ICMS se baseia na fonte documental deste Estado. Neste sentido, não podemos afirmar que os caminhos percorridos por São Paulo também constituíram as escolhas dos demais Estados brasileiros. Este é um ponto que merece especial atenção na construção desta narrativa a fim de evitarmos cair em armadilhas. 
16) - imposto de diversões sobre bilhares;

17) - taxa judiciária;

18) - taxa de expediente;

19) - taxa sobre a venda do café e outras mercadorias negociadas a termo. Parágrafo único - Também ficam abolidas quaisquer contribuições dos municípios para os cofres estaduais, excetuadas as devidas em virtude de contratos ou acordos feitos com o Estado.

Artigo $2^{\circ}$ - Ficam criados os seguintes impostos e taxas estaduais:

01) - imposto sobre vendas e consignações;

02) - imposto de indústrias e profissões;

03) - imposto sobre consumo de combustíveis para motores térmicos;

04) - imposto sobre transações;

$05)$ - taxa de conservação das estradas de rodagem estaduais;

06) - taxa de registro e fiscalização de veículos;

07) - taxa de fiscalização sanitária animal.

Capítulo II - Do imposto sobre vendas e consignações

Artigo 3 - Será uniforme, sem distinção de procedência, destino ou espécie dos produtos, o imposto sobre as vendas e consignações efetuadas no Estado por comerciantes ou produtores, inclusive os industriais.

$\S 1^{\circ}$ - Este imposto será cobrado na forma que se estatuir em regulamento, à razão de um por cento (1\%) sobre o valor da venda ou consignação, arredondadas na cobrança, para cem réis, as frações desta importância.

$\S 2^{\circ}$ - Nas vendas à vista o imposto será cobrado sobre o total das operações de cada semana, quinzena ou mês, conforme se estabelecer em regulamento.

$\S 3^{\circ}$ - São isentas do imposto:

a) as primeiras vendas ou consignações de qualquer produto, efetuadas pelos pequenos produtores, sendo assim definidos os que tiverem produção anual inferior a três contos de réis;

b) as primeiras consignações de produtos da agricultura e da criação, quando efetuadas pelos próprios produtores, desde que tais produtos não tenham sido manufaturados, semimanufaturados ou transformados, por qualquer processo industrial e os consignadores não explorem o comércio dos referidos produtos;

c) as vendas a termo, registradas em Caixa de Liquidação, quando liquidadas por diferença;

d) as vendas ou consignações de moedas e de títulos de crédito excetuados os representativos de mercadorias, tais como os "Warrants", os bilhetes de mercadorias e os conhecimentos de transporte;

e) as vendas e consignações de jornais e revistas;

f) as vendas de produtos ou subprodutos agrícolas, ou industriais, quando efetuadas pelos próprios produtores diretamente aos seus empregados ou operários, mediante lançamento em conta corrente ou desconto em folha. $\S 4^{\circ}$ - Nas vendas a prazo, o vendedor é obrigado a emitir fatura e duplicata. $\S 5^{\circ}$ - Nas consignações, o imposto será pago quando se emitir a conta de venda, depois de negociada a mercadoria.

$\S 6^{\circ}$ - Nas vendas efetuadas a comerciante, por não comerciante que não seja sociedade anônima, o imposto será pago pelo comprador. 
$\S 7^{\circ}$ - Nas vendas e consignações efetuadas para fora do país, o imposto será devido na ocasião da saída da mercadoria, sendo pago no ato da entrega da guia de exportação à repartição fiscal competente ${ }^{44}$.

$\S 8^{\circ}$ - Nos casos não regulados nos parágrafos anteriores, o imposto será pago pelo vendedor. (LEI $\mathrm{n}^{\circ} 2.485$, de 16 de dezembro de 1935)

Por meio da Lei no 2.485 , de 16 de dezembro de 1935, é possível constatar que o Estado de São Paulo optou por abolir, dentre outros, o Imposto de Exportação, sua maior fonte de arrecadação fiscal do período. Deste modo, mesmo havendo na Constituição Federal de 1934 a deliberação acerca da continuidade do Imposto de Exportação, reduzida a uma alíquota não superior a 10\%, o território paulista decidiu seguir outro caminho fiscal ao estabelecer modificações em seu sistema tributário.

À primeira vista, parece-nos precipitada tal tomada de decisão por parte de São Paulo. Afinal, ocorreu a deliberação em deixar de tributar em $10 \%$ as mercadorias exportadas e passar a promover uma tributação de tão somente $1 \%$. Entretanto, não devemos nos esquecer de uma característica fundamental presente no $I V C$, a sua cumulatividade. $\mathrm{Ou}$ seja, a cada transação comercial realizada havia a incidência tributária. Quanto maior o número de etapas percorridas pela mercadoria, desde seu local de produção até a Alfândega, maior seria também a incidência do imposto sobre o produto ${ }^{45}$.

Feitas estas considerações, retornemos à nossa reflexão histórica. O Imposto de Exportação sofreu inúmeras alterações em sua nomenclatura no decorrer dos tempos. Contudo, estamos tratando do dízimo cobrado sobre os produtos exportados para outras Províncias e países. Tal tributo foi compartilhado entre a renda geral e provincial a partir do ano de 1835, sendo transferido integralmente para os cofres estaduais em 1891.

Com o intuito de reconstruirmos os caminhos fiscais percorridos pelo Estado de São Paulo, faremos o estudo de suas Leis Orçamentárias. Contudo, antes de iniciarmos as análises destas fontes documentais, necessitamos esclarecer acerca da metodologia empregada para a sistematização das informações coletadas. Os orçamentos ora apresentados estão disponíveis no acervo histórico do sítio eletrônico da Assembleia Legislativa do Estado de São Paulo. A base de dados para a consulta é composta por Leis

\footnotetext{
${ }^{44}$ Grifo nosso;

${ }^{45}$ Esta característica fiscal levou os legisladores aos debates e reformas tributárias ocorridos na década de 1960. Nesta ocasião, o IVC foi substituído pelo ICM, pois neste novo tributo havia o preceito de extinguir os impostos em cascata, a cumulatividade. Além disso, foi instituída a proibição em promover a incidência do ICM sobre as mercadorias destinadas ao exterior.
} 
Orçamentárias que compreendem o período de 1835, primeira Lei Orçamentária da Província, a 1935, orçamento no qual o IVC passou a vigorar.

Ademais, adotamos a conduta em apresentar as Leis Orçamentárias nas quais ocorreram a alteração da nomenclatura do imposto em análise. Desta maneira, omitiremos os orçamentos que apresentam a mesma designação do tributo. Para tanto, a ordem cronológica exposta se inicia com a Lei de 1935 e retrocede no tempo, chegando a 1835. Em síntese, apuramos um século de receitas paulistas orçadas.

Além disso, precisamos fazer alguns esclarecimentos quanto à visualização das Leis Orçamentárias. Infelizmente, nem todos os documentos possuem total nitidez em sua escrita. No entanto, optamos por manter o documento original que está digitalizado no site da ALESP. No mais, mesmo havendo a falta de clareza visual em alguns documentos, a informação contida não está comprometida, sendo possível constatar a nomenclatura do imposto, sua alteração, e a representação de sua expectativa arrecadatória diante do todo.

Passemos aos levantamentos das Leis Orçamentárias do Estado de São Paulo, iniciando a investigação no ano de 1935, orçamento no qual o IVC passou a vigorar.

\section{Imagem 7 - Lei no 2.486, de 16/12/1935}

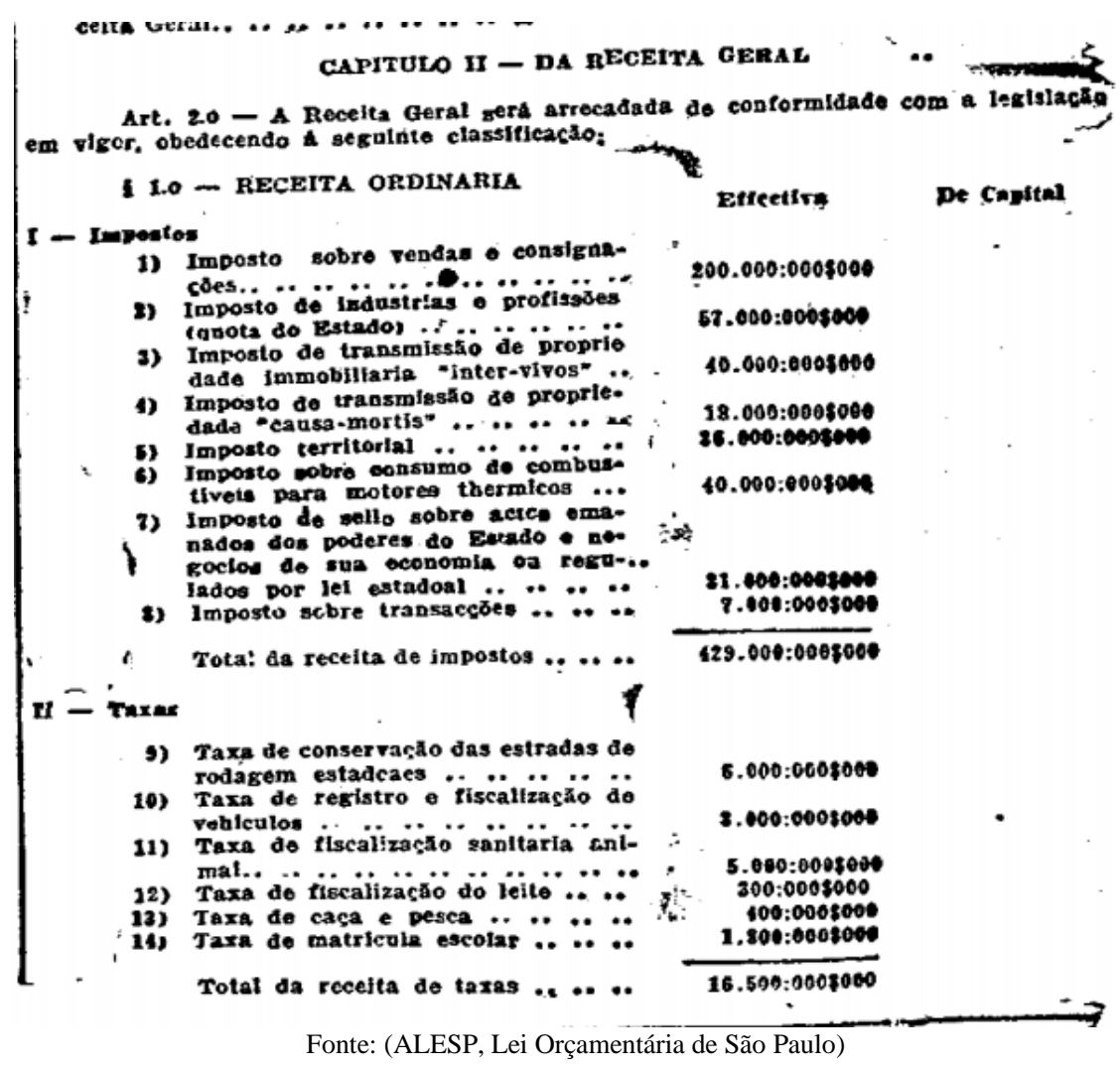


Diante da descrição dos impostos elencados na referida Lei Orçamentária, apresentados por meio da Imagem 07, dois pontos merecem destaque. O primeiro se refere ao fato de não haver na descrição da arrecadação paulista o Imposto de Exportação. A segunda constatação a ser efetuada diz respeito à representatividade do IVC diante do todo. No orçamento de 1935, correspondente ao ano financeiro de 1936, esta é a principal ferramenta de recursos fiscais para o Estado, respondendo por $46,6 \%$ da expectativa arrecadatória fiscal, excluindo-se do cômputo as taxas. Ou seja, um imposto recém-criado correspondia ao principal instrumento de recolhimento tributário paulista. Tal posição antes era ocupada pelo Imposto de Exportação.

Adiante, as demais Leis Orçamentárias demonstrarão que os anseios arrecadatórios se concentraram, majoritariamente, sobre o Imposto de Exportação e suas demais denominações. Inclusive, este imposto sempre foi o primeiro a ser especificado nas Leis Orçamentárias.

\section{Imagem 8 - Lei n' 1.529, de 28/12/1916}

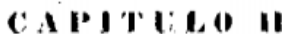

I) 1 liEtEITA

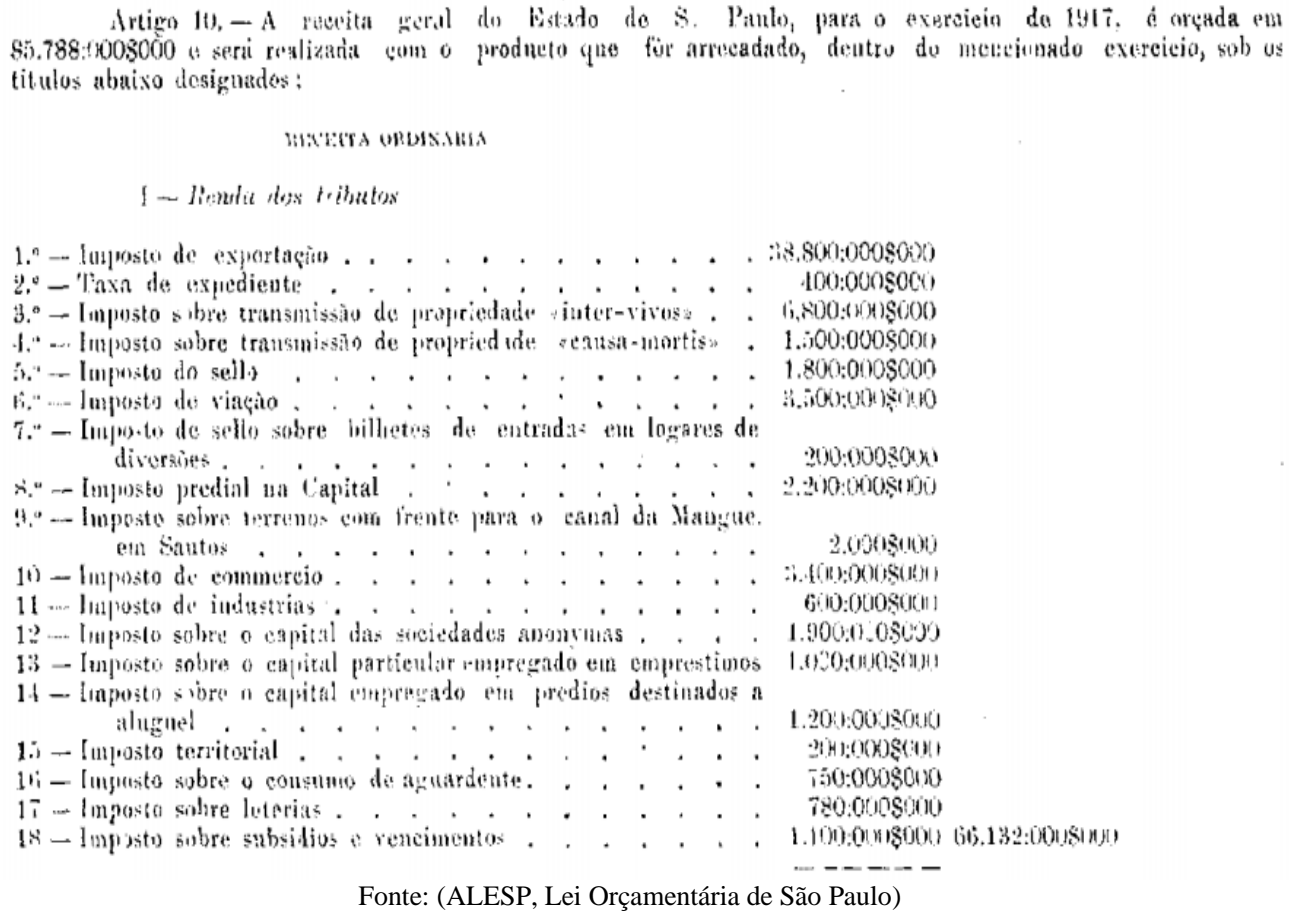

A Lei Orçamentária de 1916, para o ano financeiro de 1917, promoveu a alteração na nomenclatura do tributo, passando para a denominação Imposto de Exportação. Sendo 
assim, a Imagem 08 demonstra que em 1916 temos a última alteração no nome deste tributo antes da adoção do Imposto sobre Vendas e Consignações - IVC.

\title{
Imagem 9 - Lei $n^{0} 1.303$, de 30/12/1911
}

osto paragrapm.

\author{
DAPITULO 11
}

DA RECETTA

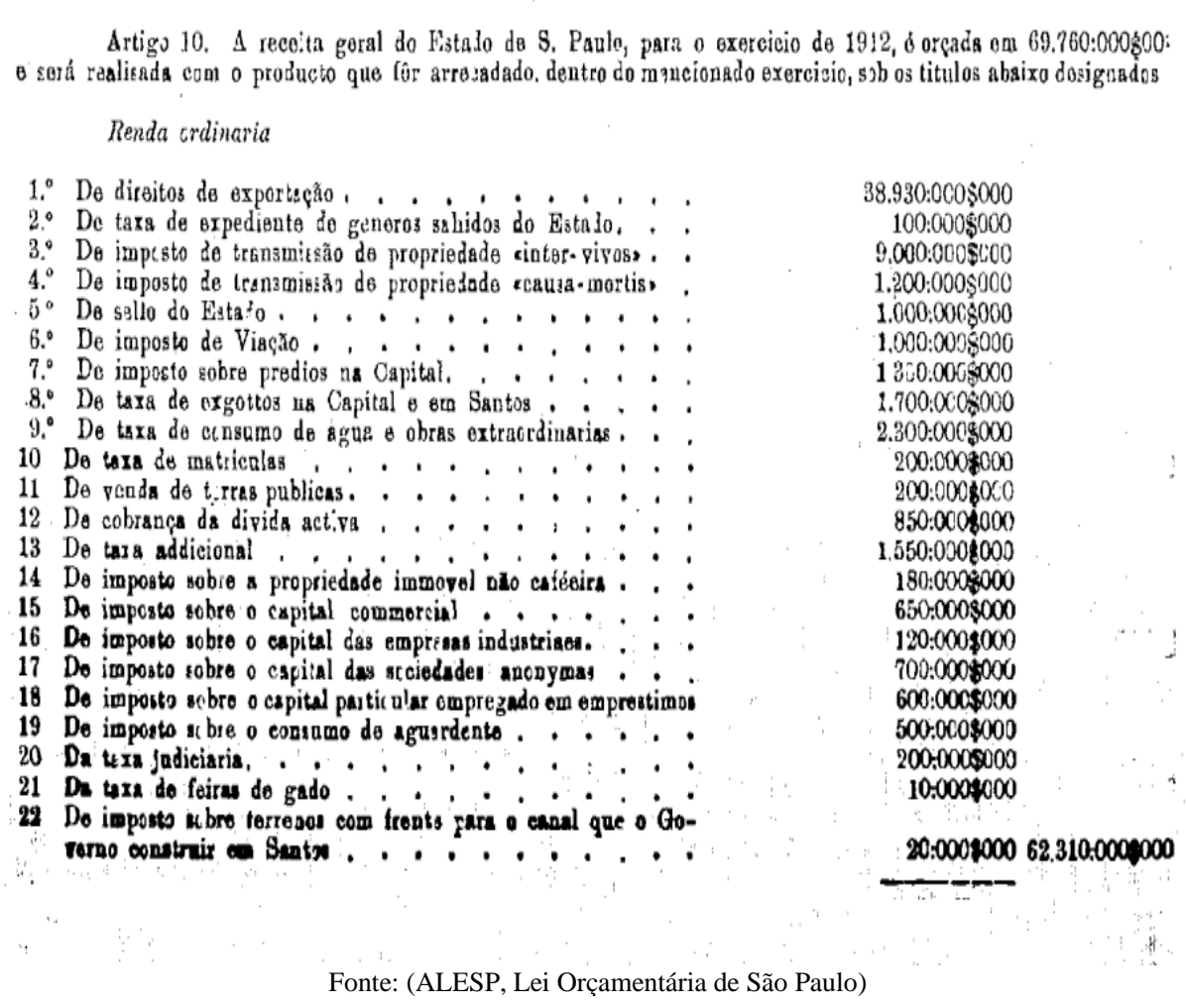

Direitos de Exportação foi a nomenclatura adotada no ano de 1911, para o ano financeiro de 1912, conforme demonstrado na Imagem 09. Ao considerarmos somente a renda ordinária, este imposto correspondeu a $62,48 \%$ da expectativa de arrecadação paulista. Diante da receita total, temos uma representatividade de $55,8 \%$.

Fato interessante é observado na Lei Orçamentária de 1904. Neste orçamento, tal imposto recebeu a denominação Direitos de Exportação do Café, corroborando com a situação econômica vivenciada por São Paulo, tendo o café como sua principal fonte de riqueza. Mesmo que esta realidade econômica não tenha se iniciado a partir do início do século $\mathrm{XX}$, temos pela primeira vez o imposto Direitos de Exportação atrelado ao termo café, conforme exposto na Imagem 10. 


\section{Imagem 10 - Lei no 936, de 17/08/1904}

\section{CAFITULO II}

DA REGETTA

Artigo 8. A receits geral do Estado de Sđa Paulo, pars o exor: cielo do 1905 . é orçada em $\$ 6.775: 000 \$ 000$ o será realiz ada com o pro. ducto do que for arrecadado, dentro do mencionaso exerciclo, aob os titulos designados:

Renta ordinaria

1. Direltos de exportaçáa do cafó

2.0 Taxa de expediento de genoros Eahidos do Estado - . . .

3.0 Imposto de transmissăo de pro. prtedado inter-vivos..+ .

4.- Imposta de transmissáo de pro. priedade caisa mortiz . - .

5. Sollo ido Estado. . . . . .

6. Imposto de traneporte ou de trans. ito : obro predios na Capital

7.- Imposto sobre predios na Capital

8.0 Taxa de exgottes na Capital e em

9. Tantos de consumo de agas e obras uxtecorlinarlas ... . .

$21.420: 0008000$

260:000\$000

3.600:000\$000

950:000\$000

$560: 0008000$

900;000\$000

$800: 000 \$ 000$

1.250:000\$060

1.200:000\$000

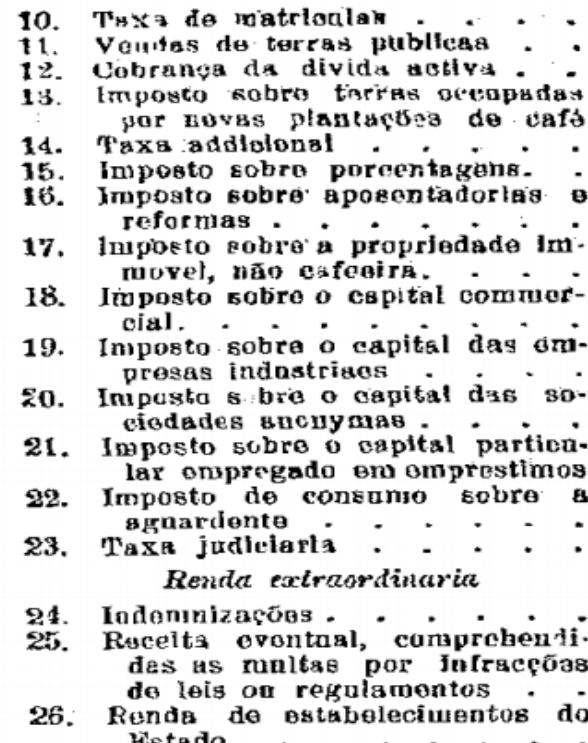

$50 \div 0008000$

25:0065000

$300.000 \$ 000$

10:0005000

620:0005000

(6):000\$000

40:0005000

200:000\$000

1.500:0005003

180:000\$000

$600000 \$ 000$

200:000\$000

700:0008000 500:000\$000

350:000\$000

200:c00\$000 Renda de estabelecímentos do

200:000\$000

36.7 75:000\$000

Fonte: (ALESP, Lei Orçamentária de São Paulo)

Na Lei Orçamentária de 1891, ilustrada na Imagem 11, observamos a nomenclatura

Direitos de Exportação dos Gêneros e Mercadorias de Produção do Estado. 


\title{
Imagem 11 - Lei $n^{0} 15$, de 11/11/1891
}

\section{CAPITULO 3. \\ IA IEEEITA}

\begin{abstract}
Artigo 6." - O Governo do Elatado, na forma das leis o regulamomcos em vigor, harf arrecadiar mo mono financeño de 1.

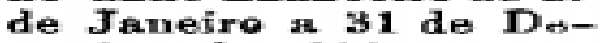
zembro de 1892 a quantia de 13.986.000\$000, palos titulos abaixo mencionados.
\end{abstract}

MESDA ORDIRARA

\$ 1. - Direitos de exportaçio dos Feunes o mereadorias de produça do Wotado

S 2. - Taxa da poute de embarque em Santos.

$8 \mathrm{~B}_{\mathrm{*}}$ " - Despachos de embareaçōes - + +

\$ 4. - Imposto de transmissão de propriedades inter-vivos.

\$ 5.:- Dito de trans: missão de propriedade causa-mortis. - . \$ 6.- Direitos de trans porte cu de tramito $\$ 7 . \circ$ Dito de sello do Estado

S 8.0 Renda do Diario Official o e Typograpbia do Fstado

\$ 9.- Imposto sobre predios da Capital

10 Venda do terras publicas do Estado..

$\$$ 11. Taxa addieionai

Sิ 12 Cobrança da divida activa................

10.000:000\$000

100-000\$000

$16: 0005000$

2.000:000\$00C

300:000\$000

350:000\$000

300:000\$000

30:000\$000

350:000\$000

20:000\$000

3-20:000\$000

80:000\$000

Renda extraordinaria

S 13 Indemnizações

Sิ 14. Receita eventual

Ş 15. Renda dos esta-

belecimientos do Estado.

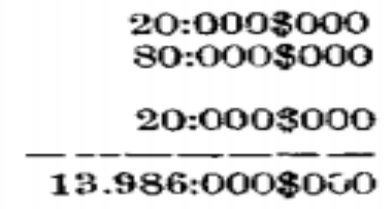

Fonte: (ALESP, Lei Orçamentária de São Paulo)

Neste orçamento, a expectativa de arrecadação com os Direitos de Exportação dos Gêneros e Mercadorias de Produção do Estado correspondeu a 71,5\% de todo o montante orçado, 13.986:000\$000. 
Ademais, nesta Lei Orçamentária temos a alteração da nomenclatura do imposto que até 1889 era denominado Direitos de Saída. Este termo foi empregado a partir de 1840, cuja descrição ainda mencionava o dízimo, conforme demonstrado na Imagem 12.

\section{Imagem 12 - Lei $n^{0} 17$, de 26/03/1840}

TITULO II.

Da receita commum da provincía.

Art. 11. Fica orçala a recsita commum da provinoia para o anno financeiro do $1^{\circ}$ de julho de $18 / 0$ a 30 de junho de $1841 \mathrm{~cm}$ conformidale das leis respectivas na forma scguinte :

$\$ 10$ Direitos de sahida da provincia denominados

dizimos . . . . . . . . . . . . . . . .

$\mathbb{S} 2^{\circ}$ Imposto sobre as aguas ardentes nacionaes $\mathrm{e}$

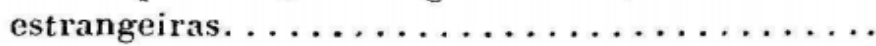

$\$ 30$ Dito sobre os armazens, tabernas e botequins

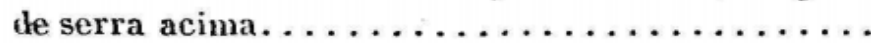

$\mathbb{4} 4^{\circ}$ Novo imposto sobre os animaes em Sorocaba.

$\$ 50$ Contribuição para Guarapuava.........

$\$ 60$ Imposto de 1, $600 \mathrm{rs}$. das rezes que se cortam e 320 rs. de subsidio litterario..........

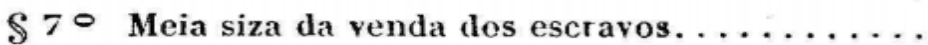

$\$ 80$ Decima dos legados e heranças...........

$\$ 9^{\circ}$ Novos e velhos direitos provinciaes........

$\$$ 10. Direitos dos animaes que passam pelo Rio Ne-

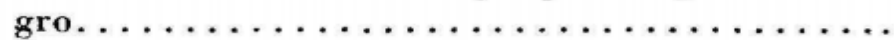

\$11. Emolumentos do lugar de secretario do go-

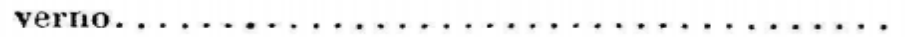

\$ 12. Despachos das embarcações...........

$\$$ 13. Imposto sobre as casas de leilão e modas......

\$14. Cobrança da metade da divida activa provincial anterior ao $1{ }^{\circ}$ de julho de 1836, e toda a divida activa dessa data em diante. . . . . . . . .

$\$$ 15. Typographia provincial. . . . . . . . .

\$16. Juros das apolices compradas por conta do cofre provineial vencidos no corrente anno.........

$\$ 17$. Renda eventual, multa sobre os contribuintes morosos, e premio dos depositos publicos......

100:000?

16:000?

10:000

8:000-77

6:2007

15:000.7

15:000.

8:000\#

2:0007

80:738.म

$150 \pi$

400.D

$200 . \not 1$

24:800-7

160.ग

1:000.p

200 का

290:848.

Fonte: (ALESP, Lei Orçamentária de São Paulo)

Adiante apresentamos a primeira Lei Orçamentária da Província de São Paulo. Por meio da Imagem 13 é possível constatar que inicialmente a nomenclatura apresentada no orçamento provincial era o dízimo. 


\section{Imagem 13 - Lei no 17, de 11/04/1835}

\section{TITULO II.}

\section{Da Receita Provincial.}

Art. 4. ${ }^{\circ}$ Fıcn orçada a Receitn Provincial no anno financeiro do 1.० de julho de 1835 ao ultimo de junho de 1836 no seguinte:

1. - Importancia dos Dizimos, a excepção dos applica. dos para a Recrita Geral pelos $\$ \S 10$, e 11 do art. 31 da lei de 8 de outubro de 1833, os quaes somente serão co. brados na forma da lei provincial respectiva............

2. ${ }^{\circ}$ Dita da imposição de 20 por cento no consumo das agons-ardentes de producção brasileira..............

3. ${ }^{\circ}$ Dita do novo imposto, ou subsidio voluntario....

4. $\odot$ Dita da Decima dos predios urbanos............

São isemptas deste imposto somente as povoaçбes, que não tiverem cem casas dentro do arruamento.

5. D Dita de foros, e arrendamentos de proprios nacionaes ..........................................

6. Dita do imposto de $1 \$ 600 \mathrm{rs}$. por cada rez que se corta, na forma da lei provincial respectiva, e do de 320 rs, de subsidio litterario.......................

7. - Dita da meia siza da venda de quaesquer escravos.

Este imposto só não so pagará quando se fizer troca de escravo por escravo, ou por bons de raiz, salvo da quantia com que se inteirar o preço do objecto de menor valo dado em troco. A acquisiçăo de liberdade por qualquer titulo não constitue venda para este effeito.

8. D Dita da decima dos legados, e heranças. . . . .

Não cstão sugcitas á este imposto as doaçōes de liberda.

i 0.1 .

$25.000 \$ 000$

$5.400 \$ 000$

$19.600 \$ 000$

$13.400 \$ 000$

$600 \$ 000$

14.0008000

$9.000 \% 000$

at

$5.400 \$ 000$

\section{$-1 \mathrm{~s}-$}

de nos escravos, nem os legados deixados á estes para fim de a conseguirom, uma vez que de facto a consig ao.

9. D Dita dos novos a velhos direitos dos titulos expediclos pelas autoridades provinciaes, inclusivè a taxa que por esto titulo pario ns fincos criminaes, a qual fica

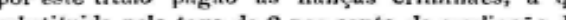

obstituida pela taxa de 2 por cento da aviliaçân dellas..

10. Dita de emolumentos do Secreturio do governo.....

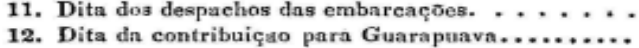

13. Dita dos animaes no registo do Rio Negro........

14. Dita do producto dns multas sobre os Mestres de

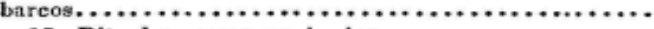

15. Dita da paseagens 4008000

Somma 175.5008000

Art. 5. C Cobrar-se-ha igualmente o Imposto sobro as casas de lei là̆o e modas se ns houverem.

Art. 6. $\%$ Fica abolido o imposto das terças partes dos officios do jus. tiça, que pagāo os escrivĩes.

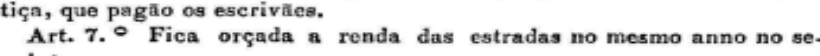

guinte:

1. - Importancia da contribuiçãa da estrada de Santos afora os saldos, e todas as dividas activas dessa cnixa.... 36.0008000

2. D Dita da de Parahibuna a Caraguatatuba......... 5008000

3. Dita da de Coritiba para Morretes, Antonina.. 4.0008000

3. Dita du de Coitibn para Morretes, o Antoninas.

4. व Dita da do So Josa dos Pinhn afora os saldos, e dividas activns dessa caixa, inclusive pela taxa sobre o gndo, que tem descido.................
5. o Dita da do Registo do Banco de Area e outras quaesquer barreiras, que se estabeleçĩo na estrada do Rio 6. 0 Dita do emprestimo autorisado para a estrada do Bananal. ....................................

7. D Dita do dito para a de Arêas.............. 8. Dita do dito para a de S. Luiz......... 2.0008000 9. Dita do dito para a de Parabibuna......... 2.0008000

10. Dita do dito para a de S. Sebastiäo......... 2.000\$

11. Dita do dito para n de Putuna............. 7009000 12. Dita do dito para a de S. José dos Pinhaes. 1.000\$000

Sommn $\overline{69.2009000}$

Art. 8. - Nito vilo orçadns nesta lei as rendas das outras barreiras, que se devem estabelecer em virtude da lei provineial respectiva.

Fonte: (ALESP, Lei Orçamentária de São Paulo) 
Finda a análise documental, buscamos traçar a trajetória do imposto hoje denominado ICMS. A reconstrução histórica deste imposto nos conduziu a 1934, ano de criação do $I V C$. Ao efetuarmos o levantamento das raízes históricas do $I V C$, por meio do estudo das Leis Orçamentárias do Estado de São Paulo constatamos que, na realidade, o IVC ampliou a matéria tributada do antigo Imposto de Exportação. Desta maneira, o Quadro 39 sintetiza a alteração das nomenclaturas do imposto no decorrer das décadas.

\section{Quadro 39 - Do Dízimo ao ICMS, São Paulo}

\begin{tabular}{|c|l|}
\hline Ano & \multicolumn{1}{|c|}{ Nomenclatura apresentada na lei orçamentária } \\
\hline 1835 & Importância dos dízimos \\
\hline 1840 & Direitos de sahida da província denominados dízimos \\
\hline 1891 & Direitos de exportação dos gêneros e mercadorias de produção do Estado \\
\hline 1904 & Direitos de exportação do café \\
\hline 1911 & Direitos de exportação \\
\hline 1916 & Imposto de exportação \\
\hline 1935 & Imposto sobre vendas e consignações - IVC \\
\hline 1967 & Imposto sobre circulação de mercadorias - ICM \\
\hline 1989 & ICMS \\
\hline
\end{tabular}

Desta maneira, por meio da análise dos documentos paulistas, chegamos à herança histórica do ICMS: o dízimo. Esta é a realidade que se apresenta na fiscalidade do Estado de São Paulo. Não pretendemos aqui defender que os demais Estados brasileiros seguiram a mesma trajetória, tal afirmativa carece de um profundo e minucioso estudo acerca do comportamento fiscal adotado pelos outros territórios. Contudo, no caso de São Paulo, a legislação e as Leis Orçamentárias ilustram os caminhos percorridos pelo dízimo, suas transformações e seu processo até a etapa na qual é instituído o IVC.

Sendo assim, um dos principais impostos de toda a história fiscal brasileira está presente nos dias atuais com uma nova nomenclatura. O dízimo, durante o Período Colonial, figurou como um imposto incidente sobre a produção, no qual os Contratadores se dirigiam à localidade produtora a fim de efetuar o recolhimento tributário.

Conforme ilustramos no decorrer deste trabalho, inúmeras motivações levaram D. João VI, no ano de 1821, a estabelecer que os dízimos incidentes sobre os principais produtos da pauta de exportação deixariam de ser cobrados nas localidades produtoras e passariam a ser coletados nos Portos Alfandegários e Registros localizados nas regiões limítrofes entre as Províncias. As demais "miunças" deveriam ser tributadas nas entradas das vilas 
e cidades. Diante desta nova configuração, o dízimo deixou de ser um imposto incidente sobre a produção e passou a tributar, principalmente, a circulação de mercadorias entre as Províncias e entre o Brasil e outras nações.

No ano de 1835, ano da primeira Lei Orçamentária provincial, a receita proveniente dos dízimos passou a ser compartilhada entre a renda geral e provincial. Contudo, sua base de tributação não foi alterada, continuou a incidir sobre a circulação de mercadorias enviadas a outras Províncias e países. Deste modo, os direitos de saída correspondiam à parcela dos antigos dízimos que pertenciam às Províncias. Os direitos de exportação, por sua vez, correspondiam à cota do Império.

Com a Proclamação da República, os direitos de exportação, que pertenciam ao governo geral, foram transferidos para o governo estadual ${ }^{46}$. Deste modo, o Estado de São Paulo em muito se favoreceu com esta medida, uma vez que produzia e comercializava a principal mercadoria da pauta de exportações brasileira, o café.

Sendo assim, até 1934 os antigos dízimos incidiam sobre as mercadorias de produção estadual que eram enviadas a outros Estados e países. Ou seja, a tributação se fazia mediante a circulação externa de mercadorias. Contudo, por meio do IVC temos a ampliação da base de incidência dos Impostos de Exportação, passando a ocorrer a tributação das mercadorias que também circulavam internamente no território estadual. Ademais, não devemos nos esquecer que em 1821 os dízimos incidentes sobre as "miunças" não foram extintos, tais mercadorias, em grande parte de consumo local, deveriam passar a ser tributadas nas entradas das vilas e cidades. Neste sentido, seria possível inquirir acerca de, em 1934, o IVC ter "reunificado" o dízimo interno e externo ${ }^{47}$ ?

Em essência, procuramos demonstrar que o principal imposto do Período Colonial continua presente e atuante até o século XXI. É bem de se ver que sua base de tributação foi se adaptando de acordo com a realidade econômica que se fazia presente no decorrer dos séculos. Entretanto, seu cerne não foi alterado, sempre incidiu e continuou a incidir sobre o consumo. Seja por meio da tributação sobre a produção ou sobre a circulação

\footnotetext{
${ }^{46}$ Nas discussões sobre o IPI verificamos que este evento levou a União a instituir, no ano de 1891, o Imposto sobre Consumo;

47 Nossas pesquisas não avançaram neste sentido, contudo, essa trajetória investigativa certamente merece ser percorrida.
} 
externa ou interna de mercadorias, o dízimo não foi extinto, atualmente o conhecemos sob o título ICMS.

\section{Imposto Municipal: ISS}

O Imposto sobre Serviços de Qualquer Natureza - ISS - foi instituído mediante a Emenda Constitucional $\mathrm{n}^{\mathrm{o}} 18$, de 01 de dezembro de 1965. Atualmente este imposto representa a principal ferramenta de recolhimento fiscal das municipalidades brasileiras. No decorrer do primeiro capítulo foi possível verificar que 50\%, em média, da receita tributária da capital paulista é constituída pelo ISS. Além disso, por meio do Quadro 12 constatamos que o ISS se caracteriza, em todo o território nacional, como a sétima ferramenta que mais gera receitas tributárias aos cofres públicos. Ficando, inclusive, acima do PIS/PASEP e do IPI.

Procurando entender as origens históricas do ISS e averiguar se, assim como nos outros impostos, suas raízes germinaram no período anterior à República, apresentaremos adiante o levantamento das legislações concernentes ao tema. No entanto, desejamos advertir o leitor que a metodologia para a apresentação desta narrativa se dará de maneira distinta das demais. No caso do ISS, optamos por expor os caminhos percorridos pelo imposto a partir do seu ponto de origem e demonstrar, paulatinamente, como ele foi se transformando no decorrer das décadas.

A justificativa para esta tomada de decisão se baseia nas seguintes características: a) o ISS foi instituído no ano de 1965 e consolida a união de três impostos - Imposto sobre Indústria e Profissões, Imposto sobre Diversões Públicas e Imposto de Licenças; $b$ ) inicialmente uma das ramificações do imposto compunha a competência tributária do Império, sendo transferida para os Estados no ano de 1891. Deste modo, foi preciso analisar a legislação e orçamento do Império, da Província e posterior Estado de São Paulo. Dadas estas circunstâncias, julgamos mais didático apresentar as inúmeras transformações ocorridas por meio da sequência cronológica. Estruturar a narrativa de modo a retroceder no tempo implicaria em possível perda de informações relevantes, pois, como veremos, ocorreram alguns hiatos entre uma medida e outra. 
Feitas estas considerações, retornemos ao Rio de Janeiro alguns anos antecedentes à Proclamação da Independência. D. João VI, ao promover algumas medidas fiscais no período, promulgou o Alvará de 20 de outubro de 1812. O dito Alvará, conhecido até os dias atuais como o Imposto do Banco possuía como objetivo levantar recursos para o Banco do Brasil, inaugurado no ano de 1808. Dentre as várias matérias tributadas especificadas nesta $\mathrm{Lei}^{48}$, evidenciemos o fato gerador descrito no parágrafo $2^{\circ}$ :

II - Igualmente se pagará por ano $12 \$ 800$ por cada loja, armazém ou sobrado em que se venda por grosso e atacado ou a retalho e varejo, qualquer qualidade de fazenda, e gêneros secos ou molhados, ferragens, louças, vidros, massames, por cada loja de ourives, lapidários, correeiros, funileiros, latoeiros, caldeireiros, cerieiros, estanqueiros de tabaco, boticários, livreiros, botequins e tavernas, sem isenção de pessoa alguma residente no Brasil que tais lojas ou armazéns tiver. Dessa contribuição somente ficarão isentas as lojas, botequins e tavernas que atualmente já pagam à Real Fazenda um igual ou maior imposto, e bem assim todas as lojas de qualquer qualidade, botequins e tavernas estabelecidas nas estradas, nos Arraiais e Capelas, e nas pequenas Povoações em que não haja Magistrado de Vara Branca. (ALVARÁ de 20 de outubro de 1812)

Por meio desta determinação, D. João VI promoveu a tributação de inúmeras lojas e profissões atuantes no Brasil no ano de 1812. Contudo, um olhar mais atento à referida lei nos mostra que tal sistemática arrecadatória já se fazia presente em solos brasileiros antes da chegada da Corte.

Por meio da consulta ao Quadro 32, verificamos que nas Províncias de Minas Gerais, São Paulo, Rio de Janeiro, Espírito Santo e Rio Grande do Sul ocorria a tributação sobre lojas, botequins e tabernas. Com exceção da Província de Minas Gerais, na qual não é possível datar o início da Contribuição do Arraial do Tejuco, verificamos que em São Paulo o Novo Imposto foi estabelecido em $1775^{49}$. Nas demais Províncias citadas, o Imposto dos Botequins e Tavernas foi instituído em 1801. Neste sentido, o Imposto do Banco promoveu a ampliação da abrangência tributária sobre as profissões e estabelecimentos comerciais, assim como instituiu a sua incidência em todo o território nacional.

No ano de 1836 verificamos algumas modificações no antigo Imposto do Banco. Tais alterações promoveram a ampliação das profissões sobre as quais haveria o recaimento

\footnotetext{
${ }^{48}$ No Quadro 33 - Tributos Diversos - informamos o conteúdo do Alvará na íntegra. No momento que ora nos ocupa iremos focar nossa atenção às informações concernentes aos tributos que constituem as raízes do atual ISS;

49 No referido Quadro consta a data de 1775 como o início do Novo Imposto. No entanto, nos levantamentos efetuados por Müller consta como data inicial o ano de 1755.
} 
tributário, além de modificarem sua alíquota, determinando a incidência de $10 \%$ sobre o aluguel das lojas. Esta nova lei foi promulgada pelo Império e direcionada à Corte e às Províncias da Bahia, Pernambuco e Maranhão. Nas demais localidades a alíquota foi mantida, contudo, as novas profissões foram incluídas:

Lei $\mathrm{n}^{\circ} 70$, de 22 de outubro de 1836

Art. $9, \S 4^{\circ}$ - O imposto estabelecido pelo $\S 2^{\circ}$ do Alvará de 20 de outubro de 1812 será substituído nesta Corte e nas capitais da Bahia, Pernambuco e Maranhão pelo novo imposto de 10 por cento do aluguel das lojas constantes do citado parágrafo, e extensivo a qualquer casa ou loja que contiver gêneros expostos à venda, seja por grosso ou a retalho; e bem assim às casas de consignação de escravos, às em que se vender carne verde, às fábricas de charutos, às cocheiras e cavalariças que contenham seges e cavalos de aluguel, e aos escritórios dos Negociantes, Advogados, Tabeliães, Escrivães, Corretores e Cambistas. Nas demais cidades e vilas do Império, sujeitas ao antigo imposto, será cobrado, como antes, sendo, porém, extensivo aos novos objetos de que trata este parágrafo. (LEI n ${ }^{\circ} 70$, de 22 de outubro de 1836)

Todavia, tais alterações não se limitaram às determinações acima. No decorrer dos anos novas alíquotas e profissões foram incluídas no Imposto das Lojas. Peguemos como exemplo a Lei $\mathrm{n}^{\circ} 317$, de 21 de outubro de 1843 :

Lei $\mathrm{n}^{\circ} 317$, de 21 de outubro de 1843

Art. 10 - O imposto das lojas, estabelecido pelo Alvará de 20 de outubro de 1812 , e pelo Art. $9, \S 4^{\circ}$, da Lei de 22 de outubro de 1836, fica elevado ao dobro do que se paga atualmente nas cidades do Rio de Janeiro, Bahia, Pernambuco e Maranhão; e nas outras cidades e vilas do Império e lugares do Município da Corte fora da cidade, será substituído por uma patente, cujo mínimo será de $12 \$ 800$, e o máximo de $40 \$ 000$ conforme a importância comercial dos lugares e estabelecimentos. As tipografias ficam também sujeitas à patente de $20 \$ 000$ a 1:000\$000 segundo a importância de cada uma;

Art. 20 - Os Despachantes das Alfândegas, não sendo os próprios donos das mercadorias, ou seus caixeiros, pagarão uma patente anual de $100 \$ 000$ a 500\$000 na Alfândega da Corte; de 50\$000 a 500\$000 nas da Bahia, Pernambuco, Maranhão e São Pedro; e de $20 \$ 000$ a $40 \$ 000$ nas mais Alfândegas do Império. Para o lançamento da patente serão os Despachantes divididos em duas classes, reguladas pela importância dos despachos que fizerem, não podendo ninguém exercer este ofício sem que tenha retirado a respectiva patente;

Art. 21 - Ficam da mesma sorte sujeitos a um direito de patente anual todos os que exercerem o ofício de Corretores, à qual será de $200 \$ 000$ a 1:000\$000 na capital do Império; de $400 \$ 000$ a 500\$000 nas cidades da Bahia, Pernambuco e Maranhão e de $20 \$ 000$ nas mais cidades marítimas do Império. (LEI n ${ }^{\circ} 317$, de 21 de outubro de 1843) 
Desta maneira, verificamos como o Imposto do Banco, instituído em 1812, passou a ser denominado Imposto das Lojas a partir de 1836. Tal nomenclatura foi mantida em 1843, porém, novamente ocorram transformações nas alíquotas e profissões abrangidas. No ano de 1860 uma nova alteração foi determinada:

Lei $\mathrm{n}^{\circ} 1.114$, de 27 de setembro de 1860

Art. $11, \S 10^{\circ}$ - Para substituir o imposto estabelecido pelo $\S 2^{\circ}$ do Alvará de 20 de outubro de 1812, e alterado pelo Art. 9, $\S 4^{\circ}$ da Lei de 22 de outubro de 1836, e Art. 10 da lei de 21 de outubro de 1843, por uma taxa, que deverá compreender todas as indústrias e profissões que forem exercidas nas diferentes cidades e vilas do Império, com exceção somente das que pela natureza privilegiada das respectivas funções, e ou pela reconhecida insuficiência e penúria de seus recursos, não a deverem ou puderem suportar. A referida taxa será em parte fixa, e em parte variável, assentando a fixa sobre a natureza, classe e condição das indústrias e profissões, e importância comercial das cidades e vilas em que forem exercidas; e a variável sobre o valor locativo do prédio, ou local, em que funcionarem. Uma e outra serão estabelecidas pelo Governo, não devendo, porém, exceder a taxa variável a 10 por cento, quando se der ao mesmo tempo o pagamento da fixa, e a 20 por cento no caso contrário. (LEI $n^{\circ}$ 1.114 , de 27 de setembro de 1860 )

Por meio desta deliberação, todas as indústrias e profissões existentes no Império no ano de 1860 passaram a compor o fato gerador do Imposto da Loja, exceto aquelas que possuíam natureza privilegiada ou reconhecida insuficiência. Ademais, sua alíquota foi dividida em duas partes. A cota fixa correspondia à relevância econômica da profissão, indústria e cidade ou vila na qual o profissional exercia suas atividades e/ou a indústria estava situada. A parcela variável era calculada levando-se em consideração o valor do aluguel pago pelas firmas ou profissionais. No entanto, no ano de 1867 uma nova alteração foi outorgada:

Lei $n^{\circ} 1.507$, de 26 de setembro de 1867

Art. 11 - O Governo fica autorizado para alterar o sistema de arrecadação do imposto sobre as indústrias e profissões, criado pelo $\S 2^{\circ}$ do Alvará de 20 de outubro de 1812, e outras leis posteriores, substituindo-o por um imposto, que será devido por toda a pessoa nacional ou estrangeira que exercer no Império qualquer indústria ou profissão, arte ou ofício, não compreendidas nas isenções estabelecidas por lei. O imposto se comporá de taxas fixas e de quotas proporcionais, sendo lançadas por forma que se obtenha a igualdade do imposto, segundo a importância relativa das indústrias e profissões. A taxa fixa terá por base a natureza e classe das indústrias e profissões, e a importância comercial das praças e lugares em que forem exercidas, ou, quanto aos estabelecimentos industriais, o número de operários, fornos, alambique e outros meios de produção, e não excederá a 2:000 $\$ 000$. A quota proporcional terá por base o valor locativo do prédio ou local que servir para o exercício da indústria ou profissão, 
compreendidos, quanto aos estabelecimentos industriais, todos os meios materiais de produção, e não excederá a $20 \%$. A taxa fixa e a quota proporcional poderão ser aplicadas isoladamente em casos excepcionais. As sociedades anônimas pagarão o imposto na razão de 1,5\% dos benefícios que se distribuírem anualmente aos acionistas. (LEI n ${ }^{\circ} 1.507$, de 26 de setembro de 1867)

Diante desta lei, temos deliberações importantes quanto ao Imposto de Indústrias e Profissões. Toda e qualquer pessoa nacional ou estrangeira que exercia alguma atividade profissional ou industrial no Império passou a ter tributada, salvo exceções. Ademais, verificamos a permanência das quotas fixas e proporcionais. Além disso, as sociedades anônimas passaram a pagar a alíquota de $1,5 \%$ sobre o benefício distribuído aos acionistas. No entanto, por mais que a denominação Indústrias e Profissões tenha surgido no ano de 1860, esta nomenclatura tributária passou a constar na Lei Orçamentária do Império somente a partir do ano de 1870.

Abaixo estão consolidadas as definições do imposto apresentadas nas Leis Orçamentárias do Império no período compreendido entre 1836 a 1870. Todavia, assim como nos estudos efetuados no tópico anterior acerca do Imposto de Exportação, optamos por omitir os anos nos quais as denominações do imposto se repetiram.

\section{Quadro 40 - O Imposto sobre Indústria e Profissões na Lei Orcamentária do Império, (1836-1870)}

\begin{tabular}{|c|c|c|c|}
\hline $\begin{array}{c}\text { Lei } \\
\text { Orçamentária }\end{array}$ & Descrição na Renda do Império & $\begin{array}{c}\text { Descrição na Renda do Município da } \\
\text { Corte }\end{array}$ & $\begin{array}{l}\text { Renda com Aplicação } \\
\text { Especial - Império }\end{array}$ \\
\hline 1836 & & Imposto nas casas de leilão e modas & $\begin{array}{l}\text { Imposto sobre as lojas, } \\
\text { conforme o Art. } 9^{\circ}, \S 4^{\circ} \\
\text { desta Lei }\end{array}$ \\
\hline 1838 & $\begin{array}{l}\text { Imposto sobre as casas de negócio, } \\
\text { assim nacionais como estrangeiras, } \\
\text { que tiverem mais de um caixeiro } \\
\text { estrangeiro, nos termos do Art. } 19 \\
\text { desta Lei }\end{array}$ & Imposto nas casas de leilão e modas & Imposto sobre as lojas \\
\hline 1843 & $\begin{array}{lccc}\text { Licenças } & \text { dos } & \text { despachantes } & \text { e } \\
\text { corretores das } & \text { Alfândegas } & \text { e } \\
\text { corretores; Imposto sobre as casas } \\
\text { em que se vendem móveis, roupa, } \\
\text { etc. }\end{array}$ & Imposto nas casas de leilão e de modas & Imposto sobres as lojas, etc. \\
\hline 1845 & $\begin{array}{l}\text { Imposto sobre as casas em que se } \\
\text { vendem móveis, roupa, \&c, } \\
\text { fabricados em país estrangeiro; } \\
\text { Licenças dos despachantes das } \\
\text { Alfândegas e Consulados }\end{array}$ & Imposto nas casas de leilão e de modas & $\begin{array}{l}\text { Imposto sobre as lojas, \&c, } \\
\text { incluídos os escritórios ou } \\
\text { casas em que se fazem } \\
\text { descontos dos vencimentos } \\
\text { dos empregados, e as que } \\
\text { emprestam dinheiro sobre } \\
\text { penhores }\end{array}$ \\
\hline 1848 & $\begin{array}{l}\text { Patentes dos despachantes e } \\
\text { corretores; Imposto sobre lojas, casas } \\
\text { de descontos, \&c; Imposto sobre as } \\
\text { casas em que se vendem móveis, } \\
\text { roupa, \&c, fabricados em país } \\
\text { estrangeiro }\end{array}$ & Imposto nas casas de leilão e de modas & \\
\hline 1859 & $\begin{array}{l}\text { Imposto dos despachantes, corretores } \\
\text { e agentes de leilões; Imposto sobre } \\
\text { lojas, casas de descontos, \&c; } \\
\text { Imposto sobre as casas em que se }\end{array}$ & Imposto nas casas de leilão e de modas & \\
\hline
\end{tabular}




\begin{tabular}{|l|l|l|l|}
\hline 1865 & $\begin{array}{l}\text { vendem móveis, roupa, \&c, } \\
\text { fabricados em país estrangeiro }\end{array}$ & $\begin{array}{l}\text { Imposto de armazéns; Imposto de tavernas; } \\
\text { Imposto de quitandas; Emolumentos de } \\
\text { Alvarás de casas de negócios; Licenças } \\
\text { para festividades; Licenças a mascates; } \\
\text { Licenças a despachantes }\end{array}$ & \\
\hline 1867 & $\begin{array}{l}\text { Imposto dos despachantes e } \\
\text { corretores e agentes de leilões; } \\
\text { Imposto sobre lojas, casas de } \\
\text { cascontos, \&c; Imposto sobre as que se vendem móveis, } \\
\text { roupa, \&c, fabricados em país } \\
\text { estrangeiro; Imposto sobre casas de } \\
\text { modas }\end{array}$ & & \\
\hline 1870 & \begin{tabular}{l} 
Imposto sobre indústrias e profissões \\
\hline
\end{tabular} & & \\
\hline
\end{tabular}

Fonte: Leis Orçamentárias do Império

Diante dos dados apresentados no Quadro 40 podemos acompanhar as transformações na nomenclatura exposta nas Leis Orçamentária do Império. No ano de 1836 o Imposto sobre as Lojas compunha a renda imperial com aplicação especial, este critério foi mantido até o ano de 1845. Ademais, notamos que a partir do ano de 1838 demais variações do Imposto da Loja passaram a compor o orçamento do Império. Tal cenário foi mantido até o ano de 1870 quando, final e definitivamente, o Imposto sobre Indústria e Profissões passou a figurar nas Leis Orçamentárias.

Mais um ponto importante a ser evidenciado mediante as observações oriundas do Quadro 40 refere-se à separação das rendas entre Império e Município da Corte. Somado a este fato, está a constatação acerca de, em 1867, essa separação deixar de ocorrer. Ademais com o advento do Imposto sobre Indústria e Profissões, o Império concentrou nesta ferramenta arrecadatória o Imposto nas casas de leilão e de modas. $\mathrm{O}$ mesmo movimento não foi acompanhado pela Província de São Paulo, que, conforme acompanhamos na descrição de suas rendas orçadas no capítulo anterior, continuou a contar com esta renda fiscal até o final do período imperial. Adiante veremos qual foi a destinação que o Estado de São Paulo deu a esta renda.

O Imposto sobre Indústrias e Profissões compôs a renda geral até o ano de 1891. No referido ano, por meio da Constituição Federal da República, esta ferramenta tributária foi transferida para os Estados, juntamente com o Imposto sobre Exportações.

O Estado de São Paulo, por meio da Lei Orçamentária nº 15, de 11 de novembro de 1891 transferiu integralmente aos Municípios o direito de arrecadar o Imposto sobre Indústrias e Profissões, assim como o Imposto sobre casas de leilão e casas de modas: 
Lei ${ }^{\circ} 15$, de 11 de novembro de 1891

Artigo 9 - Passam a pertencer às Municipalidades os seguintes títulos de receita:

01..$^{\circ}$ ) Imposto sobre casas de leilão;

02..$^{\circ}$ ) Ditos sobre seguros contra fogo;

03. ${ }^{\circ}$ ) Dito sobre casas de modas;

04..$\left.^{\circ}\right)$ Dito sobre seges e outros veículos;

05..$^{\circ}$ ) Dito sobre companhias equestres;

$06^{\circ}$ ) Dito de indústrias e profissões;

07. $\left.{ }^{\circ}\right)$ Imposto sobre capitalistas.

§ Único. - Para a cobrança do imposto da indústria e profissões, continuam em vigor o Regulamento geral a que se refere o Decreto $\mathrm{n}^{\circ} 9.870$, de 22 de fevereiro de 1888 e respectivas tabelas, na parte em que são referentes ao Estado de São Paulo, prevalecendo para o exercício de 1892 os lançamentos já feitos pelos diretores gerais, enquanto as municipalidades não ficarem definitivamente organizadas e alterarem as supracitadas leis. (LEI $n^{\circ} 15$, de 11 de novembro de 1891)

A competência tributária sobre Indústria e Profissões permaneceu integralmente com os Municípios paulistas até o ano de 1934. No entanto, no ano de 1935 o governo estadual passou a compartilhar esta renda entre os cofres estadual e municipal, na proporção de $50 \%$ para cada um.

Lei $\mathrm{n}^{\circ} 2.485$, de 16 de dezembro de 1935 - Modifica o sistema tributário do Estado

Artigo 6 - O imposto de indústrias e profissões será devido por todas as pessoas, naturais, ou jurídicas que explorarem a indústria ou comércio, em quaisquer das suas modalidades, ainda que sem estabelecimento ou localização fixa, ou exercerem qualquer profissão, arte, ofício ou função;

Artigo 7 - O imposto se comporá de uma parte fixa, por classes, tendo como base a natureza e a importância das atividades referidas no artigo anterior, conforme tabelas ns. 1,2 e 3 , e de outra variável, tendo como base o valor locativo do prédio ou local onde se exercitarem as mesmas atividades;

Parágrafo único - A parte variável é de 10\% sobre o valor locativo anual;

Artigo 18 - O lançamento do imposto de indústrias e profissões será feito pelo Estado e a arrecadação, em partes iguais, por ele e pelo município onde seja devido dito imposto. (LEI ${ }^{\circ} 2.485$, de 16 de dezembro de 1935)

Por meio da referida lei estadual, é possível observar que as características do Imposto sobre Indústrias e Profissões foram mantidas de acordo com as deliberações efetuadas pelo Império no século XIX.

Contudo, tal postura do Estado de São Paulo nos faz refletir sobre as possíveis motivações que teriam levado o governo estadual a tomar para si a metade de uma fonte de receitas 
que havia transferido aos Municípios no ano de 1891. As respostas para esta inquietação são encontradas nas medidas adotadas pelo governo federal um ano antes, 1934. Por meio da Promulgação da Constituição da República do referido ano, as cidades passaram a adquirir sua autonomia financeira, fiscal e política. Somado a este fato, está a obrigatoriedade, por parte dos Estados, em ceder algumas rendas ao Município, tal qual o governo geral havia feito nos anos de 1832, 1835 e 1891 com as então denominadas Províncias. Mediante tais medidas, temos a constituição do Pacto Federativo tal qual o conhecemos atualmente, com cada um dos entes federados gozando de autonomia própria. Além disso, no texto constitucional foi estabelecido o compartilhamento da receita proveniente de Indústrias e Profissões entre os cofres estadual e municipal.

Constituição da República dos Estados Unidos do Brasil de 1934

Art. 7 - Compete privativamente aos Estados:

e) autonomia dos Municípios;

Art. 8 - Também compete privativamente aos Estados:

$\S 2 .^{\circ} \mathrm{O}$ imposto de indústrias e profissões será lançado pelo Estado e arrecadado por este e pelo Município em partes iguais.

Art. 13 - Os Municípios serão organizados de forma que lhes fique assegurada a autonomia em tudo quanto respeite ao seu peculiar interesse, e especialmente:

I - a eletividade do Prefeito e dos Vereadores da Câmara Municipal, podendo aquele ser eleito por esta;

II - a decretação dos seus impostos e taxas, a arrecadação e aplicação das suas rendas;

III - A organização dos serviços de sua competência.

$\S 2^{\circ}$ - Além daqueles de que participam, ex vi dos arts. $8^{\circ}$, $\S 2^{\circ}$, e 10 , parágrafo único, e dos que lhes forem transferidos pelo Estado, pertencem aos Municípios:

I - o imposto de licenças;

II - os impostos predial e territorial urbanos, cobrado o primeiro sob a forma de décima ou de cédula de renda;

III - o imposto sobre diversões públicas;

IV - o imposto cedular sobre a renda de imóveis rurais;

$\mathrm{V}$ - as taxas sobre serviços municipais.

$\S 3^{\circ}$ - É facultado ao Estado a criação de um órgão de assistência técnica à Administração municipal e fiscalização das suas finanças. (CONSTITUIÇÃO FEDERAL de 1934)

Dentre as fontes de receita transferidas para os Municípios, duas merecem nossa especial atenção, o Imposto de Licenças e o Imposto sobre Diversões Públicas. No ano de 1916 o Estado de São Paulo criou o Imposto de Selo sobre bilhetes de entradas em lugares/casas de diversões. Esta renda permaneceu com os cofres estaduais até o ano de 1934, quando ocorreu a deliberação acerca de sua transferência para as municipalidades. No entanto, se 
voltarmos a consultar as informações contidas no Quadro 40, iremos identificar que no ano de 1865 o Município da Corte, além da Licença para as festividades, também criou outras Licenças. Sendo assim, acabamos de localizar as raízes destes dois impostos, elas se encontram no Município da Corte e foram instituídas no Segundo Reinado.

Dando prosseguimento à nossa análise, no ano de 1946, por intermédio de uma nova Constituição, o Imposto sobre Indústrias e Profissões foi integralmente transferido aos cofres municipais.

No ano de 1965, período no qual o Brasil vivenciou um intenso movimento com o intuito de reformar a estrutura tributária e eliminar a cumulatividade presente nas ferramentas fiscais, os três impostos acima elencados, e, desde 1946 integralmente pertencentes à competência tributária dos Municípios, foram unificados. Por meio da Emenda Constitucional $\mathrm{n}^{\circ} 18$, de 01 de dezembro de 1965 passamos a denominar os tributos municipais incidentes sobre o consumo de ISS. Além disso, a década de 1960 também testemunhou as alterações nas regras e nomenclaturas dos impostos de competência federal e estadual que tributam o consumo. A Lei $\mathrm{n}^{\circ} 4.502 / 64$ deliberou acerca do antigo Imposto de Consumo, atual IPI, pertencente ao Erário federal. A Emenda Constitucional $\mathrm{n}^{\mathrm{o}} 18$, de 01 de dezembro de 1965 , dispôs sobre o ICM, antigo IVC, fonte de receita do Erário estadual. A mesma Emenda deliberou acerca do ISS, reunindo três fontes tributárias neste imposto, de competência arrecadatória do Erário municipal.

Seção IV - Impostos sobre a Produção, e a Circulação

Art. 11. Compete à União o imposto sobre produtos industrializados. Parágrafo único. O imposto é seletivo em função da essencialidade dos produtos, e não-cumulativo, abatendo-se, em cada operação, o montante cobrado nos anteriores;

Art. 12. Compete aos Estados o imposto sobre operações relativas à circulação de mercadorias, realizadas por comerciantes, industriais e produtores;

Art. 15. Compete aos Municípios o imposto sobre serviços de qualquer natureza, não compreendidos na competência tributária da União e dos Estados. (EMENDA Constitucional $\mathrm{n}^{\circ} 18$, de 01 de dezembro de 1965)

Sendo assim, a reforma tributária ocorrida em meados do século XX procurou promover a simplificação do sistema tributário brasileiro. Acerca das medidas direcionadas aos tributos incidentes sobre o consumo, observamos a unificação de alguns tributos e o 
combate ao caráter cumulativo existente. No entanto, a matriz tributária brasileira não foi reformulada. A principal base de arrecadação, até os dias atuais, se concentra nos tributos incidentes sobre o consumo. Seja por meio da tributação interna ou externa da circulação de mercadorias, sobre a produção de gêneros ou sobre a prestação de serviços, o Brasil, no decorrer de sua história, sempre percorreu esta seara tributária.

Ademais, por meio dos estudos efetuados no decorrer deste capítulo e levantamento da legislação concernente ao tema, foi-nos possível verificar que, em realidade, não só o modelo tributário vigente constitui uma herança secular. Os próprios impostos existentes foram, no decorrer dos anos, adaptados e renomeados. Todavia, estão fortemente enraizados nas bases coloniais. 


\section{Considerações Finais}

No decorrer destas páginas procuramos apresentar a constituição e construção da estrutura fiscal brasileira. Por meio da análise dos dados do recolhimento tributário das três esferas de poder foi possível verificar o quanto a finança pública nacional, estadual e municipal depende dos recursos fiscais provenientes do consumo. Constatamos que os principais impostos e contribuições arrecadatórias constituem a base de incidência Bens e Serviços e estão entre os dez tributos que mais promovem a transferência de recursos dos agentes particulares para os agentes públicos.

Os cinco tributos que compõem a base de arrecadação sobre o consumo somam quase $50 \%$ do montante fiscal recolhido no território brasileiro. Nesta análise, o ICMS merece destaque. Este imposto, sozinho, contribui com mais de $20 \%$ da carga tributária brasileira. Somado a este fato, temos o Estado de São Paulo como maior gerador de recursos fiscais provindos do ICMS, sendo responsável, isoladamente, por aproximadamente $30 \%$ do montante nacional dos recursos oriundos deste instrumental tributário.

Ademais, não devemos nos esquecer que o território brasileiro é constituído por 26 Estados, mais Distrito Federal, e por quase 6.000 Municípios. Tal característica geográfica promove implicações no sistema tributário, pois cada uma destas localidades possui sua autonomia fiscal e financeira, bem como a liberdade para criar e gerir seus tributos.

Não obstante, este cenário corrobora para a intensa complexidade tributária vigente no Brasil, uma vez que cada ente federativo procura criar suas próprias regras fiscais que mais lhe favoreça, devendo respeitar as deliberações da Constituição Federal e do Código Tributário Nacional, saliente-se. No entanto, tais regras, na maioria das vezes, recaem na tributação sobre o consumo.

Como resultado, além da profunda caótica situação fiscal, somamos a guerra fiscal existente entre os entes subnacionais. Guerra essa prevista e debatida na ocasião da discussão sobre qual modelo político deveria ser adotado pelo Brasil na década de 1830, e consolidado em 1891, por meio da primeira Constituição Federal da República. O Pacto Federativo foi firmado. 
Deste modo, procurando sanar o belicoso embate atual entre Estados e Municípios, e descomplicar a intrincada estrutura tributária brasileira, encontram-se em tramitação no Congresso Nacional duas propostas de Reforma Tributária que visam unificar os tributos incidentes sobre o consumo em um imposto único, o IBS. Além disso, os projetos de reforma tributária estabelecem a criação de um órgão central que será responsável por todo o recolhimento fiscal e posterior distribuição dos recursos aos entes da federação que possuírem direito sobre a receita.

Em um cenário de aprovação e implantação deste Comitê Gestor unificado, nos questionamos acerca dos possíveis desdobramentos desta medida. Estaria o Brasil vivenciando um retrocesso em suas estruturas administrativas tributárias? Ou seria esta medida uma tentativa de corrigir possíveis passos hoje considerados, por alguns, errôneos ao atribuir aos Estados e Municípios excessiva autonomia financeira e fiscal? Em essência, seria o "regresso conservador" vivenciado no Período Imperial novamente ditando as diretrizes a serem seguidas?

Entretanto, as discussões em pauta não levam em consideração a reformulação do modelo tributário brasileiro, qual seja, promover a transformação do sistema vigente que incide intensamente sobre as trocas comerciais. Sendo assim, por mais que os debates políticos se façam efervescentes, a alteração da matriz fiscal raramente é considerada.

Os governantes brasileiros optaram conscientemente, no decorrer dos séculos, pela construção e manutenção de um aparato tributário incidente sobre o consumo. Seja porque este modelo promove a facilidade arrecadatória ou porque é possível ocultar as alíquotas no preço da mercadoria, dificultando a percepção da população quanto ao tributo pago, sempre se optou por percorrer esta estrada fiscal.

Por meio desta pesquisa foi possível verificar a estrutura tributária erigida no Nordeste açucareiro. O principal imposto existente na época era o dízimo incidente sobre a produção, em especial sobre o açúcar e algumas outras mercadorias destinadas ao mercado consumidor europeu. Além da predominância do dízimo, havia outros impostos e contribuições que recaíam sobre a produção e/ou consumo dos gêneros primários. Somados a estes, os impostos alfandegários também se fizeram presentes.

Com o advento da exploração de pedras e metais preciosos, o território brasileiro passou a contar com um importante mecanismo de recolhimento fiscal, a tributação incidente 
sobre a circulação de pessoas, animais e mercadorias destinadas às minas. Contudo, os impostos incidentes sobre a produção de gêneros primários não foram extintos. Ao contrário, passaram a incidir também sobre as mercadorias que seriam consumidas internamente no Brasil. Ademais, verificamos que no período que ora nos ocupa os dízimos representaram uma das principais fontes de recolhimento fiscal da Coroa, juntamente com os quintos, entradas e a dízima da Alfândega.

No ano de 1821 D. João VI procurou reformular a sistemática de arrecadação do dízimo. Por meio do Decreto de 16 de abril, o príncipe regente especificou que o dito imposto deveria deixar de ser recolhido na localidade produtora e passar a ser coletado em "postos fiscais" distribuídos ao longo do território e nas Alfândegas. Sendo assim, o dízimo deixou de incidir diretamente sobre a produção e passou a tributar a circulação de mercadorias.

A importância econômica adquirida pela intensificação e expansão do complexo cafeeiro no decorrer do Segundo Reinado nos conduziu aos estudos da fiscalidade paulista oitocentista. Por meio das Leis Orçamentárias do Estado de São Paulo foi possível acompanhar as transformações ocorridas na nomenclatura do dízimo. Além disso, verificamos a importância crescente da expectativa arrecadatória com o dito imposto, posteriormente denominado direitos de saída, incidente sobre a exportação, em especial do café, para outras Províncias e países.

Dando sequência às nossas investigações, adentramos o século XX. Ainda por meio das informações constantes nas Leis Orçamentárias paulistas, chegamos a um ponto crucial de nossa pesquisa. Foi-nos possível verificar que o atual ICMS é, na realidade, o antigo dízimo instalado no Brasil ainda no século XVI. Este fato é comprovado por meio da legislação do Estado de São Paulo. Sendo assim, um dos impostos mais importante de toda a construção fiscal brasileira continua sendo o maior angariador de recursos tributários, embora com outra nomenclatura. E mais, constatamos que os atuais Imposto sobre Produção Industrial - IPI, de competência tributária da União, e o Imposto sobre Serviços de Qualquer Natureza - ISS, de competência municipal, também possuem suas origens ou influências advindas do Período Colonial.

Deste modo, as raízes da tributação sobre o consumo se fazem substancialmente presentes e atuantes no século XXI. Por meio deste levantamento constatamos que não só o modelo fiscal atual se originou no Período Colonial e acompanhou a construção da fiscalidade brasileira. Mas os próprios impostos atualmente vigentes nos acompanharam neste 
percurso. Em essência, optou-se por promover uma pequena alteração e/ou ampliação dos fatos geradores dos antigos impostos a fim de se permitir o recolhimento fiscal condizente com cada uma das novas realidades econômicas vivenciadas em cada período de nosso passado. No entanto, no decorrer de mais de 500 anos de história, o consumo, e seus tributos, sempre foram os principais mecanismos fiscais utilizados pelo Erário, seja ele luso ou brasileiro. Seja ele federal, estadual ou municipal!

Diante do exposto, antes de nos questionarmos sobre como chegamos neste "estado de coisas", devemos refletir profundamente acerca de onde nunca saímos, e, por que nunca saímos? 


\section{Referências}

\section{Referências Bibliográficas}

AMED, José Fernando; NEGREIROS, Plínio José Labriola de Campos. História dos Tributos no Brasil. São Paulo: SINAFRESP, 2000.

ANTONIL, André João. Cultura e Opulência do Brasil: texto confrontado com o da edição de 1711; com um estudo bibliográfico de Affonso de E. Taunay; nota bibliográfica de Fernando Sales; e vocabulário e índices antroponímico, toponímico e de assuntos de Leonardo Arroyo. $3^{\text {a }}$ ed. Belo Horizonte: Ed. Itatiaia; São Paulo: Ed. da Universidade de São Paulo, 1982.

CARRARA, Ângelo Alves. Receitas e despesas da Real Fazenda no Brasil. Século XVII. Juiz de Fora: Editora UFJF, 2009.

CARRARA, Ângelo Alves. Receitas e despesas da Real Fazenda no Brasil, século XVIII: Minas Gerais, Bahia, Pernambuco. Juiz de Fora: UFJF, 2009.

CARRARA, Ângelo Alves; SANTIRÓ, Ernest Sánchez. Historiografia Econômica do Dízimo Agrário na Ibero-América: Os Casos do Brasil e Nova Espanha, Século XVIII. Estudos Econômicos, São Paulo, vol. 43, n. 1, p. 167-202, jan-mar. 2013.

CARREIRA, Liberato de Castro. História Financeira e orçamentária do império no Brasil. Brasília/Rio de Janeiro/São Paulo: Casa Rui Barbosa, 1980.

CARVALHO, José Murilo de. A Vida Política. In: CARVALHO, José Murilo de (Coordenação). A Construção Nacional: 1830-1889. Vol. 2. Rio de Janeiro: Objetiva, 2012

CASTRO, Augusto Olympio Viveiros de. História Tributária do Brasil. Brasília: ESAF, 1989.

COSER, Ivo. Visconde do Uruguai. Centralização e federalismo no Brasil - 1823-1866. Belo Horizonte: Editora UFMG / Rio de Janeiro: IUPERJ, 2008.

COSTA, Regina Helena. Curso de Direito Tributário: Constituição e Código Tributário Nacional. 6 ${ }^{a}$ edição. São Paulo: Saraiva, 2016.

DIAS, Maria Odila Leite da Silva. A interiorização da metrópole e outros estudos. São Paulo: Alameda, 2005.

EGAS, Eugenio. Galeria dos Presidentes de S. Paulo. Período Monarchico 1822-1889. São Paulo: Secção de Obras D' "O Estado de S. Paulo", 1926.

ELLIS, Myriam. Contribuição ao estudo do abastecimento das zonas mineradoras do Brasil no século XVIII. Revista de História. V.17. № 36, pp. 429-468. São Paulo, 1958.

FAZENDA, Tesouro Nacional. Disponível em: $<$ http://www.tesouro.fazenda.gov.br/fundo-pis-pasep> Acesso em 30/08/2019.

FERLINI, Vera Lúcia Amaral. Açúcar e Colonização. São Paulo: Alameda, 2010.

FURTADO, Celso. Formação Econômica do Brasil. 34a edição. São Paulo: Companhia das Letras, 2007. 
GRANDI, Guilherme; SAES, Alexandre Machione. Tarifas alfandegárias e indústria no Brasil durante a Primeira República. In: FALEIROS, Rogério Naques; GRANDI, Guilherme (org.). História Econômica do Brasil: Primeira República e Era Vargas. São Paulo: Hucitec, [s.d].

HOLANDA, Sérgio Buarque de. Raízes do Brasil. 27ª edição. São Paulo: Companhia das Letras, 2014.

LOVE, Joseph L. Federalismo y Regionalismo en Brasil, 1889-1937. In:

CARMAGNANI, Marcello (org.) Federalismos latino-americanos: México, Brasil, Argentina. México: FCE, 1993.

MACHADO, Carlos Vieira. O imposto de consumo no Brasil (1772-1922). Rio de Janeiro, 1922.

MAGALHÃES, Joaquim Romero. Labirintos Brasileiros. São Paulo: Alameda, 2011.

MAURO, Frédéric. O papel econômico do fiscalismo no Brasil colonial. In MAURO, Frédéric. Nova História e Novo Mundo. São Paulo: Perspectiva, 1969.

MÜLLER, Daniel Pedro. Ensaio d' um quadro estatístico da Província de São Paulo. São Paulo: Governo do Estado, 1978.

NOTA TÉCNICA No 38. Principais Propostas de Reforma Tributária em Tramitação no Congresso Nacional. Instituição Fiscal Independente. Brasília: Senado Federal, 2019. Disponível em: $<$ https://www2.senado.leg.br/bdsf/bitstream/handle/id/562755/NT38.pdf $>$ Acesso em: 20/11/2019.

NOZOE, Nelson; VALENTIN, Agnaldo; MOTTA, José Flávio; ARAÚJO, Maria Lucília V.; COSTA, Iraci del Nero da; LUNA, Francisco Vidal. Brasil: Breves Comentários Sobre Algumas Séries Referentes À Taxa De Câmbio. São Paulo, 2004. (mimeo)

PEREIRA, Alexandra Maria. Das Minas à Corte, de Caixeiro a Contratador: Jorge Pinto de Azeredo. Atividade mercantil e negócios na primeira metade do século XVIII. São Paulo: FFLCH/USP, 2013.

PESAVENTO, Fábio. O Colonial Tardio e a Economia do Rio de Janeiro na Segunda Metade dos Setecentos: 1750-90. Estudos Econômicos, São Paulo, vol. 42, n. 3, p. 581-614, jul.-set. 2012.

PETRONE, Maria Thereza Schorer. Considerações sobre a Tributação do Açúcar e da Aguardente Paulistas, (1765 - 1851). Revista do Instituto de Estudos Brasileiros, 1968, pp. 23-30.

PETRONE, Maria Thereza Schorer. A Lavoura Canavieira em São Paulo. São Paulo: Difusão Europeia do Livro, 1968.

PRADO JR., Caio. História Econômica do Brasil. 42ª edição. São Paulo: Brasiliense, 1995.

PRADO JR., Caio. Formação do Brasil Contemporâneo: Colônia. $8^{a}$ reimpressão. São Paulo: Companhia das Letras, 2011.

RIBAS, Marcos Caetano. História do Caminho do Ouro em Paraty. $3^{\mathrm{a}}$. Ed. Paraty: Contest Edições Culturais, 2012.

SALGADO, Graça (Coord.). Fiscais e Meirinho: A administração no Brasil Colonial. $2^{\mathrm{a}}$ edição. Rio de Janeiro: Nova Fronteira, 1985. 
SCHWARTZ, Stuart B. Segredos Internos. Engenhos e Escravos na Sociedade Colonial. São Paulo: Companhia das Letras, 1988.

TESSITORE, Viviane. As Fontes da Riqueza Pública - Tributos e Administração Tributária na Província de São Paulo, 1832-1892. Dissertação (Mestrado em História Social). São Paulo: Universidade de São Paulo, 1995.

VIEIRA, Dorival Teixeira. A política financeira. In HOLANDA, Sérgio Buarque de (org.). História Geral da Civilização Brasileira. Tomo I (A época colonial). Volume 2 (Administração, Economia, Sociedade). São Paulo: Difusão Europeia do Livro, 1973.

ZEMELLA, Mafalda P. O Abastecimento da Capitania das Minas Gerais no Século XVIII. São Paulo: Editora Hucitec, 1990.

\section{Fontes Primárias}

BRASIL, Alvará de 20 de outubro de 1812. Disponível em: $<$ https://www2.camara.leg.br/atividadelegislativa/legislacao/doimperio/colecao1.html> Acesso em: 10/10/2018.

BRASIL, Ato Adicional de 1834. Disponível em <http://www.planalto.gov.br/ccivil_03/leis/lim/LIM16.htm > Acesso em 01/05/2018.

BRASIL, Banco Central. Indicadores Econômicos Consolidados. Disponível em: $<$ http://www.bcb.gov.br/pec/Indeco/Port/indeco.asp> Acesso em: 10/04/2018.

BRASIL, Coleção das Leis do Império do. Disponível em: <https://www2.camara.leg.br/atividade-legislativa/legislacao/doimperio $>$ Acesso em: $25 / 10 / 2017$.

BRASIL, Constituição da República dos Estado Unidos do Brasil, 1891. Disponível em: $<$ http://www.planalto.gov.br/ccivil_03/constituicao/constituicao91.htm> Acesso em: 30/11/2018.

BRASIL, Constituição da República dos Estados Unidos do Brasil de 1934. Disponível em: <http://www2.camara.leg.br/legin/fed/consti/1930-1939/constituicao-1934-16julho-1934-365196-publicacaooriginal-1-pl.html> Acesso em: 13/08/2018.

BRASIL, Constituição da República Federativa do Brasil de 1988. Disponível em: $<$ http://www.planalto.gov.br/ccivil_03/constituicao/constituicao.htm> Acesso em: 20/10/2017.

BRASIL, Decreto de 16 de abril de 1821. Disponível em: $<$ https://www2.camara.leg.br/atividade-legislativa/legislacao/doimperio > Acesso em 05/08/2018.

BRASIL, Decreto de 31 de maio de 1825. Disponível em: $<$ https://www2.camara.leg.br/atividade-legislativa/legislacao/doimperio $>$ Acesso em: $13 / 08 / 2019$.

BRASIL, Emenda Constitucional nº 18/65. Disponível em: $<$ http://www.planalto.gov.br/ccivil_03/Constituicao/Emendas/Emc_anterior1988/e mc18-65.htm> Acesso em: 13/08/2018. 
BRASIL, Lei de 25 de outubro de 1827. Disponível em: <http://www4.planalto.gov.br/legislacao/legislacao-historica/leis-do-imperio-1 > Acesso em: 13/08/2018.

BRASIL, Lei de 13 de novembro de 1827. Disponível em: $\langle$ http://www4.planalto.gov.br/legislacao/legislacao-historica/leis-do-imperio-1> Acesso em: 13/08/2018.

BRASIL, Lei de 24 de Outubro de 1832 Disponível em $<$ http://www2.camara.leg.br/legin/fed/lei_sn/1824-1899/lei-37339-24-outubro1832-563870-publicacaooriginal-87921-pl.html> Acesso em 15/03/2018.

BRASIL, Lei n ${ }^{\circ}$ 99, de 31 de outubro de 1835. Disponível em: <https://www2.camara.leg.br/atividade-legislativa/legislacao/doimperio $>$ Acesso em : 10/11/2019.

BRASIL, Lei no 70, de 22 de outubro de 1836. Disponível em: <https://www2.camara.leg.br/atividade-legislativa/legislacao/doimperio $>$ Acesso em: $10 / 11 / 2019$.

BRASIL, Lei no 317, de 21 de outubro de 1843. Disponível em: $<$ https://www2.camara.leg.br/atividade-legislativa/legislacao/doimperio $>$ Acesso em: $10 / 11 / 2019$.

BRASIL, Lei $\mathrm{n}^{\circ} 1.114$, de 27 de setembro de 1860. Disponível em: <https://www2.camara.leg.br/atividade-legislativa/legislacao/doimperio $>$ Acesso em: 10/11/2019.

BRASIL, Lei $n^{\circ} 1.507$, de 26 de setembro de 1867. Disponível em: <https://www2.camara.leg.br/atividade-legislativa/legislacao/doimperio > Acesso em: 10/11/2019.

BRASIL, Lei n ${ }^{\circ} 25$, de 30 de dezembro de 1891. Disponível em: $<$ https://www2.camara.leg.br/legin/fed/lei/1824-1899/lei-25-30-dezembro-1891545783-publicacaooriginal-59165-pl.html> Acesso em: 10/11/2019.

BRASIL. Lei n ${ }^{\circ}$ 4.502/64. Disponível em: <http://www2.camara.leg.br/legin/fed/lei/1960-1969/lei-4502-30-novembro-1964376851-publicacaooriginal-1-pl.html > Acesso em 13/08/2018.

BRASIL, Lei Complementar no 87/96. Disponível em: <http://www2.camara.leg.br/legin/fed/leicom/1996/leicomplementar-87-13setembro-1996-370965-norma-pl.html> Acesso em 13/08/2018.

BRASIL, Receita Federal do. Carga Tributária no Brasil - 2016. Análise por Tributos e Bases de Incidência, 2017. Disponível em: $<$ http://idg.receita.fazenda.gov.br/dados/receitadata/estudos-e-tributarios-eaduaneiros/estudos-e-estatisticas/carga-tributaria-no-brasil/carga-tributaria2016.pdf.> Acesso em: 20/03/2018.

BRASIL. Receita Federal do. Tabela TIPI. Disponível em: <http://receita.economia.gov.br/acesso-rapido/legislacao/documentos-earquivos/tipi-1.pdf/view> Acesso em: 30/11/2019.

BRASIL, Relatório do Ministério da Fazenda do. Disponível em: < http://ddsnext.crl.edu/titles/106> Acesso em: 05/09/2019. 
IBGE, Instituto Brasileiro de Geografia e Estatística. Panorama. Disponível em: $<$ https://cidades.ibge.gov.br/brasil/panorama> Acesso em: 10/07/2018.

SÃO PAULO. Lei Orçamentária da Província de. Disponível em: <https://www.al.sp.gov.br/acervo-historico/> Acesso em 27/12/2017.

SÃO PAULO, Lei n ${ }^{\circ} 15$, de 11 de novembro de 1891. Disponível em: <https://www.al.sp.gov.br/norma/64100> Acesso em: 04/12/2019.

SÃO PAULO, Lei no 2.485 , de 16 de dezembro de 1935. Disponível em: <https://www.al.sp.gov.br/norma/63435> Acesso em: 04/12/2019.

SÃO PAULO, Portal da Transparência da Prefeitura de. Receitas. Disponível em $<$ http://transparencia.prefeitura.sp.gov.br/Paginas/home.aspx. >. Acesso em: 29/05/2018.

SÃO PAULO, Secretaria da Fazenda do Estado de. Relatório da Receita Tributária do Estado de, fev./2017. Disponível em:

$<$ https://portal.fazenda.sp.gov.br/acessoinformacao/Paginas/Relat\%C3\%B3rios-daReceita-Tribut\%C3\%A1ria.aspx > Acesso em: 25/03/2018.

\section{Bibliografia Consultada}

AMED, Fernando José; NEGREIROS, Plínio José Labriola de Campos. História dos Tributos no Brasil, São Paulo: Edições SINAFRESP, 2000.

ANTONIL, André João. Cultura e Opulência do Brasil: texto confrontado com o da edição de 1711; com um estudo bibliográfico de Affonso de E. Taunay; nota bibliográfica de Fernando Sales; e vocabulário e índices antroponímico, toponímico e de assuntos de Leonardo Arroyo. $3^{\text {a }}$ ed. Belo Horizonte: Ed. Itatiaia; São Paulo: Ed. da Universidade de São Paulo, 1982.

ATALIBA, Geraldo. Hipótese de Incidência Tributária, 4. Ed. São Paulo: RT, 1990.

BALTHAZAR, Ubaldo Cesar. História do Tributo no Brasil. Florianópolis: Fundação Boiteux, 2005.

BERCOVICI, Gilberto. Constituição Econômica e Desenvolvimento - uma leitura a partir da Constituição de 1988. São Paulo: Malheiros, 2005.

BORREGO, Maria Aparecida de Menezes. A teia mercantil. Negócios e poderes em São Paulo colonial. São Paulo: Alameda, 2010. Referência alternativa: BORREGO, Maria Aparecida de Menezes. A teia mercantil: negócios e poderes em São Paulo colonial (1711-1765). Tese de Doutorado apresentada ao Programa de PósGraduação em história Social do Departamento de História da Faculdade de Filosofia, Letras e Ciências Humanas da USP. São Paulo: 2007. (mineo) Disponível em: $<$ http://www.teses.usp.br/teses/disponiveis/8/8138/tde-16072007-112028/ptbr.php $>$

BUESCU, M.. Organização e Administração do Ministério da Fazenda no Império (I ed., Vol. 13). (V. Tapajós, Ed.) Brasília: Fundação Centro de Formação do Servidor Público, 1984.

CARMAGNANI, Marcello (org.) Federalismos latino-americanos: México, Brasil, Argentina. México: FCE, 1993. 
CARRARA, Ângelo Alves. Receitas e despesas da Real Fazenda no Brasil. Século XVII. Juiz de Fora: Editora UFJF, 2009.

CARRARA, Ângelo Alves. Receitas e despesas da Real Fazenda no Brasil, século XVIII: Minas Gerais, Bahia, Pernambuco. Juiz de Fora: UFJF, 2009.

CARRARA, Ângelo Alves; SANTIRÓ, Ernest Sánchez. Historiografia Econômica do Dízimo Agrário na Ibero-América: Os Casos do Brasil e Nova Espanha, Século XVIII. Estudos Econômicos, São Paulo, vol. 43, n. 1, p. 167-202, jan-mar. 2013.

CARREIRA, Liberato de Castro. História Financeira e orçamentária do império no Brasil. Brasília/Rio de Janeiro/São Paulo: Casa Rui Barbosa, 1980.

CARVALHO, José Murilo de. A Vida Política. In: CARVALHO, José Murilo de (Coordenação). A Construção Nacional: 1830-1889. Vol. 2. Rio de Janeiro: Objetiva, 2012

CASTRO, Augusto Olympio Viveiros de. Tratado dos Impostos (Estudo Teórico e Prático). Rio de Janeiro: Imprensa Nacional, 1910.

CASTRO, Augusto Olympio Viveiros de. História Tributária do Brasil. Brasília: ESAF, 1989.

CAVALCANTI, Severiano de Andrade. Histórico dos impostos de consumo. Volume II. Rio de Janeiro: Ministério da Fazenda/Imprensa Nacional, 1924.

COSER, Ivo. Visconde do Uruguai. Centralização e federalismo no Brasil - 1823-1866. Belo Horizonte: Editora UFMG / Rio de Janeiro: IUPERJ, 2008.

COSTA, Bruno Aidar. A Tessitura do Fisco. A política ilustrada de D. Rodrigo de Souza Coutinho e a administração fiscal da capitania de São Paulo, 1797-1803. Dissertação de Mestrado apresentada ao Programa de Pós-Graduação em Economia da Universidade Estadual de Campinas. Campinas, 2007. Disponível em: <http://www.bibliotecadigital.unicamp.br/document/?code=vtls000435693 $>$

COSTA, Emília Viotti da. Da Monarquia à República. Momentos decisivos. São Paulo: Editora UNESP, 1999.

COSTA, Regina Helena. Curso de Direito Tributário: Constituição e Código Tributário Nacional. 6 ${ }^{a}$ edição. São Paulo: Saraiva, 2016.

CUNHA, P. O. Política e Administração de 1640 a 1763. In: S. B. HOLANDA, História Geral da Civilização Brasileira (Vol. 2). São Paulo: Difusão Europeia do Livro, 1973.

DANIELLI, Maria Isabel Basilisco Célia. Economia Mercantil de Abastecimento e Rede Tributária. São Paulo, Séculos XVIII e XIX. Tese de Doutorado apresentada ao Programa de Pós-Graduação em Economia da Universidade Estadual de Campinas. Campinas, 2006. Disponível em: <http://www.bibliotecadigital.unicamp.br/document/?code=vtls000410190 >

DEVEZA, Guilherme. Política tributária no período imperial. In HOLANDA, Sérgio Buarque de (org.) História Geral da Civilização Brasileira. São Paulo: Difusão Europeia do Livro, 1971. Tomo II (O Brasil monárquico). Volume 4 (Declínio e queda do Império), pp. 61-84.

DIAS, Maria Odila Leite da Silva. A interiorização da metrópole e outros estudos. São Paulo: Alameda, 2005. 
DOLHNIKOFF, Miriam. O pacto imperial. São Paulo: Globo, 2005.

EGAS, Eugenio. Galeria dos Presidentes de S. Paulo. Período Monarchico 1822-1889. São Paulo: Secção de Obras D' "O Estado de S. Paulo", 1926.

ELLIS, Myriam. Contribuição ao estudo do abastecimento das zonas mineradoras do Brasil no século XVIII. Revista de História. V.17. № 36, pp. 429-468. São Paulo, 1958.

EZEQUIEL, Márcio. Receita Federal: história da administração tributária no Brasil. Brasília: Secretaria da Receita Federal do Brasil, 2014.

FAORO, Raymundo. Os donos do poder. São Paulo: Globo, 1991.

FERLINI, Vera Lucia Amaral. O município no Brasil colonial e a configuração do poder econômico. In SOUZA, Laura de Mello e; FURTADO, Júnia Ferreira; BICALHO, Maria Fernanda (orgs.) O governo dos povos. São Paulo: Alameda, 2009, pp. 389-399. GOVERNO DO ESTADO DE SÃO PAULO. Secretaria de estado dos Negócios da Fazenda do Estado de São Paulo. Evolução HistóricoFuncional. São Paulo: Imprensa Oficial do estado, 1979.

FERLINI, Vera Lúcia Amaral. Açúcar e Colonização. São Paulo: Alameda, 2010.

FERNANDES, Fernando Lourenço. A feitoria portuguesa do Rio de Janeiro. História, Franca, V. 27, n. 1, 2008.

FERNANDES, Guilherme Vilela. Tributação e Escravidão: O imposto de meia siza sobre o comércio de escravos da província de São Paulo (1809-1850). Campinas. Informes de Pesquisa, Almanack Braziliense. No 02, nov. 2005, p. 102.

FERREIRA, Benedito. A história da tributação no Brasil - causas e efeitos. Brasília (s.n.), 1986.

FLEIUSS, M. História Administrativa do Brasil (2 ed.). Rio de Janeiro, 1925.

FURTADO, Celso. Formação Econômica do Brasil. 34ª edição. São Paulo: Companhia das Letras, 2007.

GIAMBIAGI, F; ALÉM, A.C. Finanças públicas: teoria e prática no Brasil. Rio de Janeiro: Editora Campus, 2007.

GRANDI, Guilherme; SAES, Alexandre Machione. Tarifas alfandegárias e indústria no Brasil durante a Primeira República. In: FALEIROS, Rogério Naques; GRANDI, Guilherme (org.). História Econômica do Brasil: Primeira República e Era Vargas. São Paulo: Hucitec, [s.d].

GRECO, Marco Aurélio; GODOI, Marciano Seabra. Solidariedade social e tributação. São Paulo: Dialética, 2005.

HANLEY, Anne G. A Failure to Deliver: municipal poverty and the provisiono f public services in imperial São Paulo, Brazil, 1822-1889. Journal of Urban History, 39(3) 513-535. Doi 10.1177/0096144212440886. Disponível em: <http://juh.sagepub.com/content/39/3/513.abstract>

HANLEY, Anne G.; LOPES, Luciana Suarez. Can Public Accounts be Trusted? Evidence from the Historical Record in São Paulo, Brazil 1836-1850 (mimeo)

HESPANHA, António Manuel. A constituição do Império português. Revisão de alguns enviesamentos correntes. In FRAGOSO, João; BICALHO, Maria Fernanda; 
GOUVÊA, Maria de Fátima. (orgs.) O Antigo Regime nos trópicos. Rio de Janeiro: Civilização Brasileira, 2001, pp. 163-188.

HOLANDA, Sérgio Buarque de. Raízes do Brasil. 27ª edição. São Paulo: Companhia das Letras, 2014.

IMPERIO DO BRAZIL. Collecção das Leis do Império do Brazil (1828). (Vol. Parte Primeira). Rio de Janeiro: Typographia Nacional, 1878.

JUNG, Guether. Escola de Administração Fazendária: uma visão histórica. Brasília: Esaf, 2013.

LANGONI, Carlos Geraldo. Distribuição da renda e desenvolvimento econômico do Brasil. 3 ed. Rio de Janeiro: Editora FGV, 2005.

LOPES, Luciana Suarez. Saldos e Sobras: finanças públicas municipais na primeira metade do oitocentos. História e Economia Revista Interdisciplinar. Disponível em: <http://bbs.edu.br/wp-content/uploads/2015/02/V.10.pdf $>$

LOPES, Luciana Suarez; HANLEY, Anne G. Alice no País da Contabilidade: a aventura de Duas Historiadoras Econômicas em Registros Contábeis do Século XIX. Revista Contabilidade e Finanças - USP, São Paulo, v. 25, Edição "História da Contabilidade”, pp. 355-363, set./out./nov./dez. 2014. Disponível em: <http://www.scielo.br/pdf/rcf//v25nspe/pt_1519-7077-rcf-25-spe-0355.pdf >

LOVE, Joseph L. Federalismo y Regionalismo en Brasil, 1889-1937. In:

CARMAGNANI, Marcello (org.) Federalismos latino-americanos: México, Brasil, Argentina. México: FCE, 1993.

MACHADO, Carlos Vieira. O imposto de consumo no Brasil (1772-1922). Rio de Janeiro, 1922.

MADEIRA, Mauro de Albuquerque. Letrados, Fidalgos e Contratadores de Tributos no Brasil Colonial. Brasília: Unafisco, 1993.

MAGALHÃES, Joaquim Romero. Labirintos Brasileiros. São Paulo: Alameda, 2011.

MANDETTA, Savério. Impostos, taxas e contribuições: resenha histórica do regime fiscal no Brasil. São Paulo: Colibras, s.d.

MARTINS, Ives Gandra da Silva. Sistema tributário na Constituição de 1988. 4. ed. São Paulo: Saraiva, 1992.

MAURO, Frédéric. O papel econômico do fiscalismo no Brasil colonial. In MAURO, Frédéric. Nova História e Novo Mundo. São Paulo: Perspectiva, 1969.

MAXWELL, Kenneth. A devassa da devassa. São Paulo: Paz e Terra, 2009.

MIRANDA, Marcia Eckert. A Estalagem e o Império. São Paulo: HUCITEC, 2009.

MONTORO, Eugênio Augusto Franco. A organização do Município na Federação Brasileira. Tese de Doutorado apresentada ao Programa de Pós-Graduação em Direito pela Pontifícia Universidade Católica de São Paulo. São Paulo, 1974.

MÜLLER, Daniel Pedro. Ensaio d' um quadro estatístico da Província de São Paulo. São Paulo: Governo do Estado, 1978.

NOBREGA, Cristóvão Barcelos da. História do imposto de renda no Brasil, um enfoque da pessoa física (1922-2013). Brasília: Receita Federal, 2014.

NOBREGA, Mailson. O Brasil em transformação. São Paulo, Editora Gente, 2000. 
NOZOE, Nelson Hideiki. São Paulo: Economia Cafeeira e Urbanização. São Paulo: IPE-USP, 1984.

NOZOE, Nelson; VALENTIN, Agnaldo; MOTTA, José Flávio; ARAÚJO, Maria Lucília V.; COSTA, Iraci del Nero da; LUNA, Francisco Vidal. Brasil: Breves Comentários Sobre Algumas Séries Referentes À Taxa De Câmbio. São Paulo, 2004. (mimeo)

NOZOE, Nelson Hideiki. Vida econômica e finanças municipais da capital paulista na época imperial. In: PORTA, Paula (Org.). História da cidade de São Paulo. São Paulo: Paz e Terra, 2004, v. 2, pp. 99-151.

OLIVEIRA, Fabricio Augusto de. Evolução da estrutura tributária e do fisco brasileiro: 18892009. Texto para discussão no 1469. Brasília: Ipea, 2010. Disponível em: <http://www.en.ipea.gov.br/agencia/images/stories/PDFs/TDs/td_1469.pdf>

PEREIRA, Alexandra Maria. Das Minas à Corte, de Caixeiro a Contratador: Jorge Pinto de Azeredo. Atividade mercantil e negócios na primeira metade do século XVIII. São Paulo: FFLCH/USP, 2013.

PEREIRA, Ivone Rotta. A Tributação na História do Brasil. São Paulo: Moderna, 1999.

PESAVENTO, Fábio; GUIMARÃES, Carlos Gabriel. Contratos e contratadores do Atlântico Sul na segunda metade do Setecentos. Revista História, Histórias. Brasília, vol. 1, n. 1, 2013, pp. 72-87.

PETRONE, Maria Thereza Schorer. Considerações sobre a Tributação do Açúcar e da Aguardente Paulistas, (1765-1851). Revista do Instituto de Estudos Brasileiros, 1968, pp. 23-30.

PETRONE, Maria Thereza Schorer. A Lavoura Canavieira em São Paulo. São Paulo: Difusão Europeia do Livro, 1968.

PIRES, J. M. Um estudo de história econômica regional sob a ótica das finanças públicas. São Paulo: (mimeo), 1994.

PRADO JR., Caio. História Econômica do Brasil. 42ª edição. São Paulo: Brasiliense, 1995.

PRADO JR., Caio. Formação do Brasil Contemporâneo: Colônia. $8^{a}$ reimpressão. São Paulo: Companhia das Letras, 2011.

PUNTONI, Pedro. O Estado do Brasil: poderes médios e administração na periferia do império português. In: ARRUDA, José Jobson; FONSECA, Luís Adão da. (orgs.) Brasil - Portugal: história, agenda para o milênio. Bauru: EDUSC; São Paulo: FAPESP; Portugal: ICCTI, 2001.

RIBAS, Marcos Caetano. História do Caminho do Ouro em Paraty. $3^{\text {a }}$. Ed. Paraty: Contest Edições Culturais, 2012.

RICUPERO, Rodrigo. Governo-geral e a formação da elite colonial baiana no século XVI. In: BICALHO, Maria Fernanda; FERLINI, Vera Lúcia Amaral. Modos de governar. São Paulo: Alameda, 2005, pp. 119-135.

SALGADO, Graça (Coord.). Fiscais e Meirinho: A administração no Brasil Colonial. $2^{\mathrm{a}}$ edição. Rio de Janeiro: Nova Fronteira, 1985.

SARAIVA, José Hermano. História concisa de Portugal. 20. Ed. Lisboa: Europa América, 1999. 
SCHWARTZ, Stuart B. Segredos Internos. Engenhos e Escravos na Sociedade Colonial. São Paulo: Companhia das Letras, 1988.

SILVEIRA, José Patrocínio da. Tributos sobre Bens e Serviços no Brasil: Retrospectiva e Perspectiva. Brasília: [s.n].

SIMONSEN, Roberto C. História Econômica do Brasil (1500-1820) 4. Ed. São Paulo: Editora Nacional, 1962.

SIQUEIRA, R.B.; NOGUEIRA, J.R.; SOUZA, E.S. Os impostos sobre o consumo no Brasil são regressivos/ Revista Economia Aplicada, 2000.

SIQUEIRA, R.B.; NOGUEIRA, J.R.; SOUZA, E.S. A incidência Final dos Impostos Indiretos no Brasil: Efeitos da Tributação de Insumos. Revista Brasileira de Economia, 2001.

SOUZA, Carlos Fernando Mathias de. Breve Passeio pela História do Direito Brasileiro passando pelos tributos. Série Monografias do CEJ, v. 8. Brasília: Conselho de Justiça Federal, s.d.

SOUZA, Laura de Mello e. Desclassificados do Ouro. A pobreza mineira no século XVIII. Rio de janeiro: Graal, 1986.

SOUZA, Laura de Mello e. Política e administração colonial: problemas e perspectivas. In: SOUZA, Laura de Mello e; FURTADO, Júnia Ferreira; BICALHO, Maria Fernanda. (orgs.). O governo dos povos. São Paulo: Alameda, 2009, pp. 63-89.

SOUZA, M. C. S. Tributação Indireta no Brasil: eficiência versus equidade. Revista Brasileira de Economia, vol. 50, No 1, pp. 03-20, 1996.

TESSITORE, Viviane. As Fontes da Riqueza Pública - Tributos e Administração Tributária na Província de São Paulo, 1832-1892. Dissertação (Mestrado em História Social). São Paulo: Universidade de São Paulo, 1995.

VARNHAGEN, Francisco Adolfo de. História geral do Brasil: isto é, do descobrimento, colonização, legislação e desenvolvimento deste estado, hoje império independente, escrita em presença de muitos documentos autênticos recolhidos nos arquivos do Brasil, Portugal, da Espanha e da Holanda. Por um sócio do Instituto Histórico do Brasil, natural de Sorocaba. Tomo Primeiro. Rio de Janeiro: E. e H. Laemmert, 1854.

VIANNA. S. W. et al. Carga Tributária Direta e Indireta sobre as Unidades Familiares no Brasil: Avaliação de sua incidência nas Grandes Regiões Urbanas 1996. Brasília: Ipea, 2000 (Texto para Discussão $n^{\circ}$ 757).

VIEIRA, Dorival Teixeira. A política financeira. In HOLANDA, Sérgio Buarque de (org.). História Geral da Civilização Brasileira. Tomo I (A época colonial). Volume 2 (Administração, Economia, Sociedade). São Paulo: Difusão Europeia do Livro, 1973.

ZEMELLA, Mafalda P. O Abastecimento da Capitania das Minas Gerais no Século XVIII. São Paulo: Editora Hucitec, 1990. 